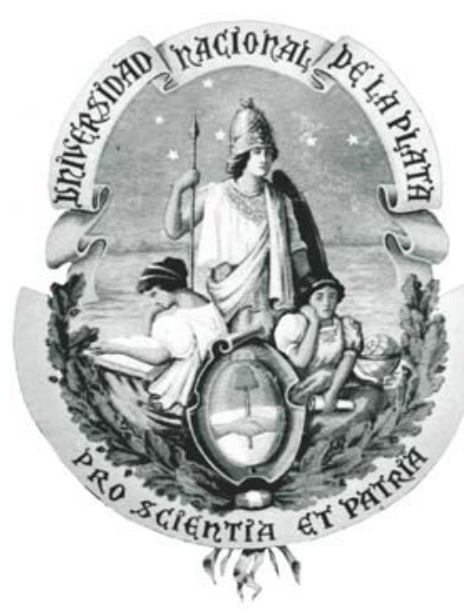

UNIVERSIDAD NACIONAL DE LA PLATA

Facultad de Ciencias Naturales y Museo

\title{
“ESTUDIOS MORFOLÓGICOS, ANATÓMICOS, TAXONÓMICOS Y RELACIONES FILOGENÉTICAS DE LAS ESPECIES DE FESTUCA DEL CONO SUR (ARGENTINA, CHILE, URUGUAY, PARAGUAY Y SUR DE BRASIL)"
}

Tesis presentada para optar al grado de Doctor en Ciencias Naturales de la Universidad Nacional de La Plata

Autor: Lic. Juan Camilo Ospina González Instituto de Botánica Darwinion (ANCEFN-CONICET) Facultad de Ciencias Naturales y Museo, UNLP

Directoras: Dra. Silvia S. Denham y Dra. Sandra S. Aliscioni 
Dedicado a:

María Mirtha González Patiño "la Mirtis"
Matías Naranjo "el mono"
Diego Giraldo Cañas

Susana Dalone

Gabriela Elias

Flia. Ospina Martinez, Flia. González Patiño y Flia. Abratte Dalone

Colombia y Argentina 


\section{AGRADECIMIENTOS}

A mis directoras de tesis Silvia Denham y Sandra Aliscioni por toda la paciencia, dedicación y enseñanza en lo que respecta a este trabajo.

A Fernando Zuloaga (director del instituto Darwinion), por brindarme constante apoyo y ánimo para seguir adelante (...!metele, metele....!) e incluso, por compartir pacientemente y en numerosas ocasiones, charlas para tratar de sortear los futuros pasos en la investigación y llevar a cabo gran parte de este trabajo durante estos años.

A Christian Zanotti (hermano y compañero de enormes batallas), por enseñarme a trabajar con lealtad, sinceridad, alegría, sonrisas y encontrar el sosiego en este momento de mi vida.

A Diego Salariato (compañero de enriquecedores debates), por ampliar mi campo visual compartiendo sus ideas y sueños académicos, en los cuales coincido.

A Francisco Rojas y Marcelo Moreno, por compartir grandiosos momentos y proporcionar los detalles más importantes en las ilustraciones.

A Raúl Pozner, por brindarme conocimientos de Anatomía y microscopía en el 2010, la primera oportunidad que tuve de venir al Instituto Darwinion, y gracias a éste acercamiento se logró gestar la presentación de la beca doctoral ante CONICET con el apoyo del Fernando Zuloaga, Diego Giraldo Cañas y mis directoras.

A todas las personas que conocí en el Darwinion, entre 2011 y 2015: Adela Panizza, Adolfina Savoretti, Alicia López, Alejandro Escobar, Amalia Scataglini, Amalia Suárez, Ana Lorenzo, Ana María Cialdella, Agostina Sassone, Carolina Godoy Bürki, Carolina Guerreiro, Claudio Libertelli, Cristian Larsen, Erika Werner, Estrella Urtubey Fernanda Ihasz, Gabriel Lombardi, Gabriela del Valle Elías, Gabriela Nadra, Graciela Hernández, Horacio Illarraga, Jorge Hurst, Juan Manuel Acosta, Julia Bena, Liliana Giussani, Liliana Mallo, Lone Aagesen, Luciana Salomón, Lucio Zavala, Mabel Lizarazu, Mabel Suescún, Manuel Belgrano, Marcela Nicola, Marcelo Díaz, Mariana Valente, Mariela Suárez, Mónica Ponce, Mónica Ihasz, Nataly O'Leary, Nicolas Brignone, Norma Deginani, Pablo Moroni, Paola Corvalán, Pedro Gelaezzi, Roberto Donadío, Sabina Donadío, Santiago Morello, Sergio Sclovich Soledad Nomdedeu, Susana Freire, Renata Reinheimer y Zulma Rúgolo De Agrasar.

Quienes ofrecieron lo mejor de cada uno de ellos para compartir muchos contextos distintos durante mi estadía.

A los curadores y las curadoras de los herbarios que facilitaron el material de estudio. Además, a todas las personas que estuvieron atentas y me acogieron durante mis visitas a diferentes lugares: St. Beck, Steven Sylvester, Mitsy Sylvester, Tiina Shärkinen, Gina Castillo, Nora Muruaga, Rosa Isela, Asunción A. Cano E., Maria Isabel La Torre, Gloria Rojas, Mélica Muñoz, Michael O. Dillon, Rosy Montero, Alicia Marticorena, y Victor L. Finot.

A mi querida Colombia (COLCIENCIAS), quien guarda con recelo mis primeros paso en la investigación y gracias a su cooperación con la bella Argentina (CONICET); país que brindó sin medida diferentes riquezas para llevar a cabo mi doctorado y parte de mi vida en ella. 


\section{INDICE GENERAL}

\section{RESUMEN}

\section{ABSTRACT}

\section{AGRADECIMIENTOS}

\section{CAPÍTULO I: INTRODUCCIÓN GENERAL, HIPÓTESIS Y OBJETIVOS}
ANTECEDENTES 1

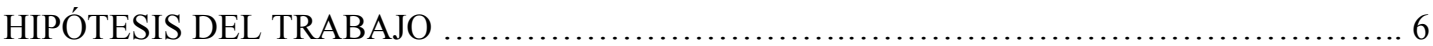

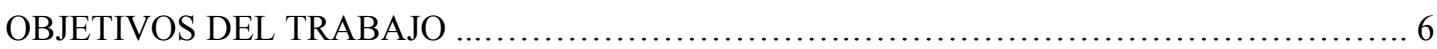

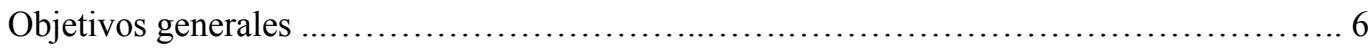

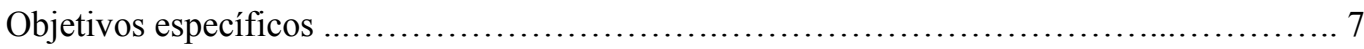

\section{CAPÍTULO II: COMPLEJO DE ESPECIES: FESTUCA CHRYSOPHYLLA}

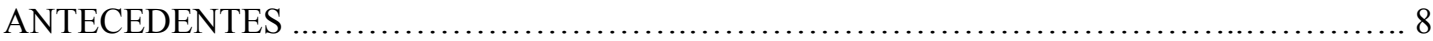

\section{MATERIALES Y MÉTODOS}

Estudio y selección del material de herbario ......................................... 10

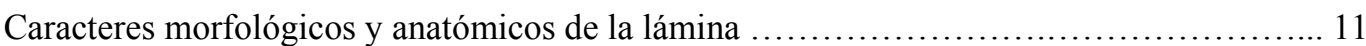

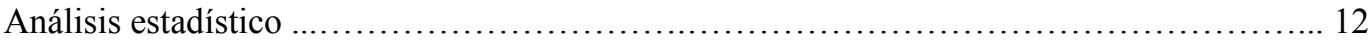

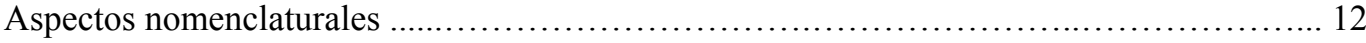

RESULTADOS Y DISUSIÓN

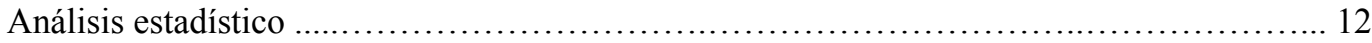

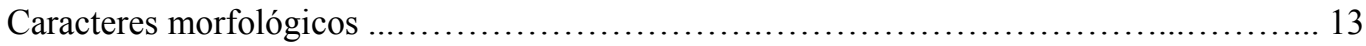

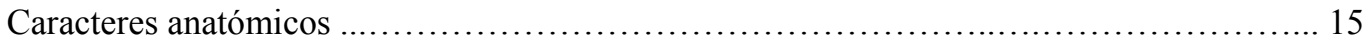

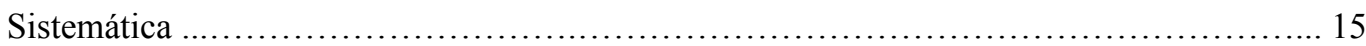

MATERIAL DE HERBARIO ESTUDIADO .............................................. 16

CAPÍTULO III: TRATAMIENTO TAXONÓMICO DEL GÉNERO FESTUCA PARA EL CONO SUR

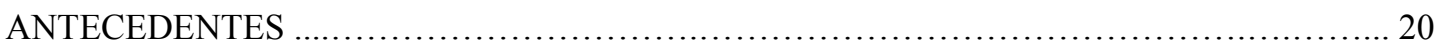

MATERIALES Y MÉTODOS

Bibliografía consultada 
Material de herbario consultado ........................................................... 22

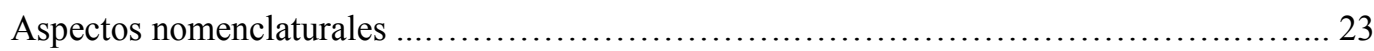

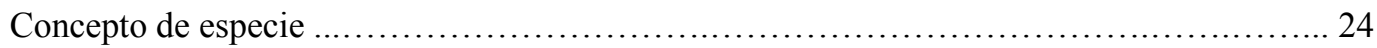

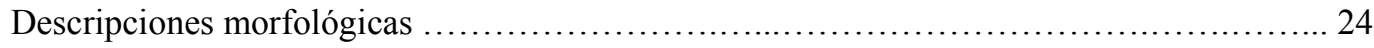

Distribución geográfica y regiones fitogeográficas ................................... 25

RESULTADOS

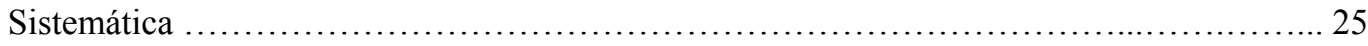

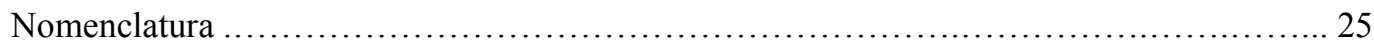

Novedades corológicas para el Cono Sur ......................................... 25

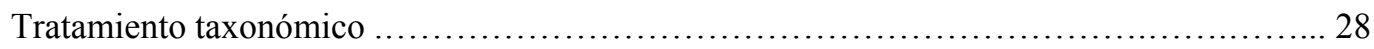

Clave para diferenciar las especies de Festuca para el Cono Sur ............................ 28

Descripción de las especies de Festuca para el Cono Sur ............................... 33

Especies de Festuca excluidas para el Cono Sur ................................... 93

Especies de Festuca dudosas para el Cono Sur ..................................... 94

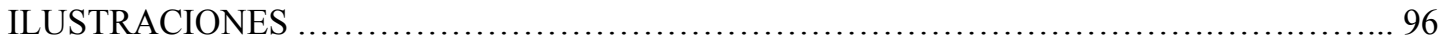

\section{CAPÍTULO IV: ANATOMÍA Y MICROMORFOLOGÍA FOLIAR DE LAS ESPECIES DE FESTUCA DEL CONO SUR}

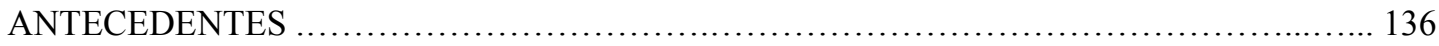

\section{MATERIALES Y MÉTODOS}

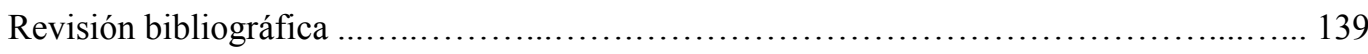

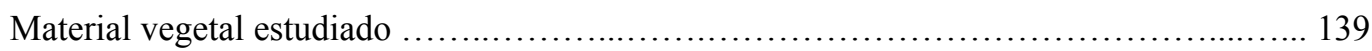

Exploración y registro de los atributos anatómicos vistos al microscopio óptico (MO) ...... 140

Exploración y registro de los atributos micromorfológicos vistos con microscopio electrónico

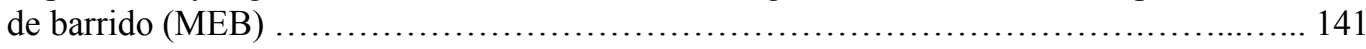

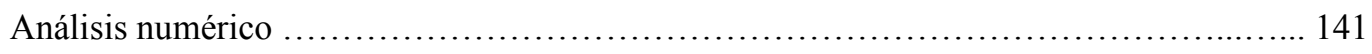

Relación entre la estructura foliar y la distribución altitudinal .......................... 143

\section{RESULTADOS}

Caracterización general de la anatomía foliar en corte transversal ...................... 143

Caracterización de la micromorfología epidérmica foliar .............................. 146

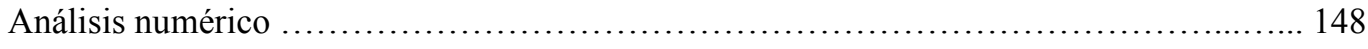




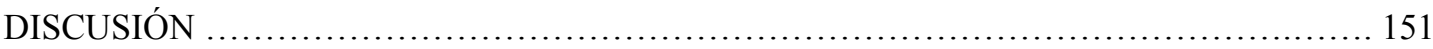

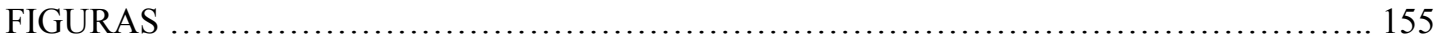

\section{CAPÍTULO V: APROXIMACIÓN A LAS RELACIONES FILOGENÉTICAS DE LAS ESPECIES SUDAMERICANAS DE FESTUCA}

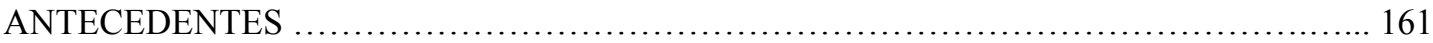

\section{MATERIALES Y MÉTODOS}

Selección de taxones y material de estudio .......................................... 164

Extracción de ADN, amplificación y secuenciación de marcadores ....................... 166

Alineamiento de las secuencias y análisis filogenéticos ................................ 167

RESULTADOS Y DISCUSIÓN

Descripción de los marcadores moleculares y de las matrices …........................ 168

Descripción y discusión de los árboles obtenidos ....................................... 169

Análisis de las relaciones filogenéticas de las especies americanas de Festuca .............. 173

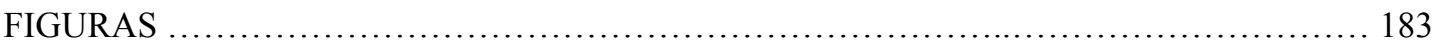

\section{CAPÍTULO VI: CONTRASTE DE HIPÓTESIS Y CONCLUSIONES}

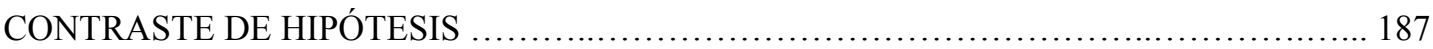

\section{CONCLUSIONES}

Conclusiones taxonómicas sobre las especies de Festuca en el Cono Sur....

Conclusiones sobre anatomía y micromorfología de las especies de Festuca del Cono Sur ......

Conclusiones sobre las relaciones filogenéticas de las especies sudamericanas de Festuca

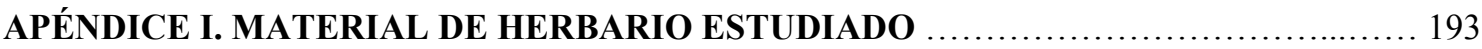

APÉNDICE II. REFERENCIAS BIBLIOGRÁFICAS _.................................. 217 


\section{RESUMEN}

El género Festuca L. pertenece a la tribu Poeae, subtribu Loliinae (familia Poaceae, subfamilia Pooideae) y comprende cerca de 500 especies que se distribuyen en las regiones templadas de todo el mundo y también se extienden sobre las cimas de las montañas en los trópicos. El género es principalmente diverso en el hemisferio norte, en la zona holártica de Eurasia y América del Norte. En América del Sur crecen aproximadamente 220 taxones que se encuentran concentrados principalmente en las regiones Altoandina y Patagónica.

Festuca se caracteriza por incluir plantas perennes, frecuentemente cespitosas, espiguillas con varios antecios y lemas 5-nervias con el dorso redondeado, las cariopsis presentan el hilo típicamente lineal. Como es frecuente en la mayoría de los grandes géneros de gramíneas, la taxonomía de Festuca es compleja y los límites de las especies suelen ser imprecisos. Existen tratamientos taxonómicos para varias regiones o países, aunque se conocen mejor las especies del hemisferio norte. Para Sudamérica se publicaron valiosos tratamientos taxonómicos por países o regiones menores, pero no un tratamiento integral para un área extensa.

La anatomía foliar ha sido ampliamente estudiada en el género, y desde los estudios pioneros se la utilizó como herramienta para la identificación de especies. La mayoría de los trabajos taxonómicos realizados en Festuca combinan caracteres exomorfológicos con caracteres anatómicos, en particular para las especies denominadas de "hoja fina" que presentan mayor dificultad para su determinación.

El género Festuca se relaciona con los géneros Vulpia C.C. Gmel. y Lolium L., además, con otros numerosos géneros pequeños (Psilurus Trin., Ctenopsis De Not., Narduroides Rouy, Wangenheimia Moench, Cutandia Willk. y Micropyrum (Gaudin) Link.); todos ellos integran la subtribu Loliinae. Existe una serie de trabajos de filogenia en Loliinae que muestran a la subtribu como monofilética, mientras que Festuca, con su circunscripción actual, sería un género parafilético. Estos estudios están basados en marcadores moleculares y un amplio muestreo de taxones de la subtribu, aunque con pocos representantes sudamericanos. Estos estudios muestran dos grandes linajes, uno con especies de "hoja ancha" y otro linaje de origen más reciente con especies de "hoja fina"; además de linajes menores, varios de ellos con una clara señal biogeográfica.

Así, esta tesis tiene por objetivos contribuir a la sistemática de la subtribu Loliinae a través del estudio de las especies de Festuca de Sudamérica; estudiar la morfología, micromorfología y la anatomía foliar de las especies del Cono Sur de Sudamérica; realizar un tratamiento taxonómico para las especies del Cono Sur e incluir especies sudamericanas a la filogenia de la subtribu Loliinae y analizar los linajes que integran. 
Para ello se estudiaron ejemplares de herbario y plantas vivas en su hábitat; se analizaron sus caracteres morfológicos (vegetativos y reproductivos) y se propusieron límites a las especies que crecen en la región del Cono Sur, también se precisó para cada especie su distribución geográfica. Se realizó un tratamiento taxonómico donde se identificó un total de 41 especies y 2 variedades de Festuca que crecen en el Cono Sur, F. dolichophylla J. Presl., F. buchtienii Hack., Festuca juncifolia St.-Amans, Festuca magensiana Potztal., Festuca tectoria St.-Yves fueron excluidas de esta región y se registraron como nuevas citas para Chile ( $F$. weredermannii St.-Yves) y para Argentina $[F$. rigescens (J.Presl) Kunth.

Por medio de un detallado análisis nomenclatural, el estudio de material tipo y los protólogos, se establecieron 18 nuevos sinónimos, se designaron 23 lectotipos de primer paso y 16 de segundo paso. Este trabajo representa el mayor tratamiento taxonómico de Festuca para el continente, por el área geográfica que abarca.

Se utilizaron técnicas estadísticas (análisis multivariados) para resolver objetivamente los límites específicos en el complejo de especies de Festuca chrysophylla Phil., que presentaba especial complejidad.

Se estudió la anatomía y micromorfología foliar por medio de la observación de cortes transversales de láminas y preparaciones de epidermis adaxial y abaxial, utilizando microscopía óptica y electrónica de barrido. También se llevó a cabo un análisis estadístico multivariado con caracteres anatómicos y micromorfológicos para definir grupos de especies de acuerdo a sus características foliares. Se detectaron patrones foliares anatómicos-micromorfológicos que se analizaron en función del rango altitudinal donde crecen los diferentes taxones. Sobre la similitud de los caracteres anatómicos y micromorfológicos, las especies se reunieron en cuatro tipos foliares diferentes, uno correspondiente al denominado "hoja ancha" cuyas especies se distribuyen hasta los $3000 \mathrm{~m}$ s.m., y tres tipos foliares dentro del denominado "hoja fina" cuyas especies logran los mayores niveles de distribución altitudinal.

Se incluyeron 23 taxones sudamericanos (67 secuencias) a la última filogenia publicada para la subtribu Loliinae (Inda et al. 2008). Para ello se obtuvieron secuencias nucleotídicas de los marcadores plastidiales trnT-L y trnL-F y del nuclear ITS. Se realizaron análisis de inferencia bayesiana y de máxima parsimonia para las diferentes particiones (marcadores plastidiales y nucleares) y para la matriz combinada. Se recuperaron los linajes más importantes de la subtribu, como los linajes hoja ancha, hoja fina y linajes menores, aunque con algunas variantes con respecto a lo publicado anteriormente. Se concluye que la incorporación de más taxones sudamericanos es fundamental para comprender la historia evolutiva de la subtribu, y que las especies sudamericanas de Festuca provienen de diferentes linajes. Además, este trabajo permitió confirmar y ampliar la información sobre linajes con representantes americanos (Asian-American, Neozeylandic I- American, American I 
y American II), permitió evidenciar un emplazamiento ambiguo del clado intermedio Asian-American; se abrió nuevos interrogantes sobre las relaciones de los clados en las ramas basales del clado de hojas finas; permitió relacionar más especies de Festuca sudamericanas con especies de Vulpia; permitió confirmar y amplíar hipótesis previas sobre distribuciones históricas y su relación con los niveles de ploidía de los taxones sudamericanos.

Palabras clave: anatomía, descripción de especies, Festuca, filogenia, Loliinae, nomenclatura, nuevos registros, taxonomía, Suramérica.

\begin{abstract}
The genus Festuca L. belongs to the tribe Poeae, subtribe Loliinae (family Poaceae, subfamily Pooideae) and comprises about 500 species distributed in temperate regions around the world and also in the tropics, at higher altitudes at the mountains. The genus is mainly diverse in the Northern Hemisphere, in the Holartic area of Eurasia and North America. About 220 taxa grow in South America, mainly concentrated in the Andean and Patagonian regions.
\end{abstract}

Festuca is characterized by including perennial plants, often cespitose, spikelets with several florets and five-nerved lemmas, dorsally rounded; the caryopses have linear hilum. As in most large genera of grasses, Festuca taxonomy is complex and species boundaries are often inaccurate. Taxonomic treatments for various regions or countries are available, but Northern Hemisphere species are better known. In Southern America, valuable taxonomic treatments for small regions or countries have been published, but not a comprehensive treatment for a wide area.

The leaf anatomy has been extensively studied in the genus, and since the early studies, it has been used for species identification. In most Festuca taxonomic works, exomorphological characters combined with anatomical features are used, especially for "fine leaved" species, which are more difficult to distinguish.

The genus Festuca is related to Vulpia C.C. Gmel. and Lolium L. and also with other small genera (Psilurus Trin., Ctenopsis De Not., Narduroides Rouy, Wangenheimia Moench, Cutandia Willk. y Micropyrum (Gaudin) Link.); all of them comprising subtribe Loliinae. There are a number of papers dealing with Loliinae phylogeny that show the subtribe as monophyletic, while Festuca, with its current circumscription, appears as paraphyletic. These studies are based on molecular markers and a large sample of taxa, although few South American species are included. These studies show two major lineages, one of them with "broad leaved" species and another lineage of more recent origin with "fine leaved" species, plus several minor lineages, many of them with a clear biogeographic signal. 
The aims of this work is to contribute to the systematic of the subtribe Loliinae, through the study of Festuca species in South America; to study the morphology, micromorphology, and leaf anatomy of species of the Southern Cone of South America; to make a taxonomic treatment of the species of that region; and to include South American species in the Loliinae phylogeny to analyze the lineages where they evolved.

Herbarium specimens and living plants in their habitat were studied; morphological characters (vegetative and reproductive ones) were studied to define species growing in the Southern Cone, and to establish the geographical distribution of each one. A taxonomic treatment for a total of 41 species and 2 varities of Festuca that occur in the Cono Sur, F. dolichophylla J. Presl., F. buchtienii Hack., Festuca juncifolia St.-Amans, Festuca magensiana Potztal., Festuca tectoria St.-Yves were excluded from this region, and new records for Chile (F. weredermannii St.-Yves) and Argentina [F. rigescens (J. Presl.) Kunt] were recorded.

Through a detailed nomenclatural analysis and the study of type materials and protologues, 18 new synonyms and 23 lectotopifications for first step, and 16 for second step were established. This work represents the major Festuca taxonomic treatment for the continent, because of the geographical area covered. Statistical techniques (multivariate analysis) were used to objectively address the specific limits on the Festuca chrysophylla complex, a difficult group of species.

Leaf anatomy and micromorphology were studied by leaf cross sections and adaxial and abaxial leaf surfaces slides, using optical and scanning electron microscopy. A multivariate statistical analysis with anatomical and micromorphological characters was also conducted to define groups of species according to their leaf characteristics. The leaf anatomical-micromorphological patterns detected were analyzed as a function of the altitude range where the species grow. Based on the similarity of the anatomical and micromorphological characters, species gathered in four different leaf types; one of them corresponding with the so-called "broad leaved" species, distributed up to $3000 \mathrm{~m}$ asl, and the remainder three leaf types corresponding with the so-called "fine leaved" species, which achieve higher elevations.

Twenty three South American taxa (67 sequences) were included in the more recent paper for Loliinae phylogeny (Inda et al. 2008). Nucleotide sequences of trnT-L and trnL-F plastid markers and ITS nuclear marker were obtained. Bayesian inference and maximum parsimony analysis were performed to different partitions (plastid and nuclear markers) and to the combined matrix. The most important lineages of the subtribe were recovered, like broad-leaved and fine-leaved, and some other minor lineages, but with some variations with respect to the previously published phylogeny. It is concluded that the incorporation of more South American taxa is central to understanding the evolutionary history of the subtribe, and that the South American species of Festuca have evolved from different lineages. In addition, this work allowed to confirm and improve the knowledge of lineages with 
American representatives (Asian American, I- Neozeylandic American, American American I and II); show an ambiguous location of the Asian American intermediate clade; open new questions about the relationship of the basal clades; allowed to relate more South American species of Festuca with Vulpia; and allow to confirm and extend prior assumptions about historical distributions and their relationship with ploidy levels of South American taxa.

Key words: anatomy, species descriptions, Festuca, phylogeny, Loliinae, nomenclature, new records, taxonomy, South America. 


\section{CAPÍTULO I}

\section{INTRODUCCIÓN GENERAL, HIPÓTESIS Y OBJETIVOS}

\section{ANTECEDENTES}

El género Festuca L. pertenece a la familia Poaceae, subfamilia Pooideae, tribu Poeae. En esta tribu es característica la posesión de espiguillas del tipo pooide, con glumas cortas y varias flores, y lemas 5-nervias (Tzvelev 1982, Clayton \& Renvoize 1986), comprende especies con metabolismo $\mathrm{C}_{3}$, de zonas frías o templadas. Dentro de la tribu hay dos grandes géneros, Festuca y Poa L., cada uno de ellos con cerca de 500 especies distribuidas en todo el planeta y restringidas a altas altitudes en zonas tropicales y subtropicales (Watson \& Dallwitz 1992). Ambos géneros presentan otros géneros afines o satélites, marcando dos grandes líneas dentro de las Poeae.

El género Festuca presenta varios géneros derivados o satélites de acuerdo a Clayton \& Renvoize (1986): Castellia Tineo, Cynosurus L., Lamarckia Moench, Micropyropsis Romero Zarco \& Cabezudo, Micropyrum (Gaudin) Link, Psilurus Trin. y Wangenheimia Moench, entre otros; mientras que Tzvelev (1982) menciona a otros géneros que también forman parte del linaje de Festuca: Cutandia Willk., Loliolum V.I. Krecz. \& Bobrov, Lolium L., Nardus L., Scleropoa Griseb. y Vulpia C.C. Gmel. La afinidad de Lolium con Festuca ha sido corroborada desde hace tiempo por características de los cromosomas y por hibridaciones espontáneas y artificiales (Jenkin 1933, Malik \& Thomas 1966). También se han detectado híbridos entre especies de Vulpia y Festuca (Ainscough et al. 1986). Actualmente, muchos de estos géneros, junto con Festuca, conforman la subtribu Loliinae Dumort. Los estudios filogenéticos más recientes muestran a la subtribu como monofilética, mientras que Festuca, con su circunscripción actual, sería un género parafilético. El estudio de esta subtribu es muy relevante ya que se trata de uno de los grupos de pastos más grande y ampliamente distribuido en las regiones templadas del mundo, con importancia ecológica y económica.

La subtribu incluye importantes especies forrajeras del hemisferio norte (Festuca pratensis Huds., F. arundinacea Schreb., F. rubra L., F. ovina L.), pero también algunas especies nativas del hemisferio sur han sido citadas como buenas forrajeras: Festuca chrysophylla Phil., F. hieronymi Hack., F. gracillima Hook. f. y F. pallescens (St.-Yves) Parodi (Parodi 1953). Algunas especies de alta montaña, como F. eskia Ramond ex DC. y F. gautieri (Hack.) K. Richt., se usaron para restaurar ambientes alpinos altamente modificados, mientras que $F$. glauca Vill. se usa como planta ornamental (Catalán 2006). Lolium perenne L. y L. multiflorum 
Lam. son usadas como céspedes o para pastoreo, mientras que L. rigidum Gaudin es una maleza.

Las aproximadamente 500 especies de Festuca están distribuidas en todos los continentes, excepto en la Antártida. El género se distribuye ampliamente en el hemisferio norte y es principalmente diverso en la zona holártica de Eurasia y América del Norte. Es un componente importante de los ecosistemas de las zonas templadas y templado-frías, mientras que en las zonas tropicales y subtropicales su distribución se limita a las altas montañas (Clayton \& Renvoise 1986, Watson \& Dallwitz 1992).

Como se mencionó antes, el género Festuca presenta un metabolismo fotosintético $\mathrm{C}_{3}$, con anatomía foliar del tipo non-Kranz, caracterizado por tener haces vasculares rodeados por dos vainas, ambas sin cloroplastos, o la externa con escasos cloroplastos similares a los del mesófilo, el cual se dispone de manera irregular (Brown 1975). Las características fisiológicas de las plantas $\mathrm{C}_{3}$, como un alto punto compensación de $\mathrm{CO}_{2}$ atmosférico, un intervalo óptimo de temperatura entre $10-25^{\circ} \mathrm{C}$ y un punto de saturación lumínica bajo (Hattersley \& Watson 1976 , Hooghiemstra \& van der Hammen 2004), permiten su desarrollo en zonas muy frías y de altura. Por estas características fisiológicas y por su alto número de especies, el género Festuca juega un rol ecológico muy importante en pastizales y estepas xerofíticas y mesofíticas del mundo (Strömberg 2011); y en el hemisferio sur forma parte fundamental de las comunidades de pastizales de altura (Stančík 2003, Stančík \& Peterson 2007) ya que está muy bien adaptado a las condiciones extremas a lo largo de la cordillera de Los Andes y la región subantártica (Inda et al. 2008).

El género Festuca incluye plantas perennes, densamente cespitosas o, menos frecuentemente, rizomatosas o estoloníferas, con hojas anchas o delgadas. Las inflorescencias son panículas abiertas o generalmente lineares y poco ramificadas. Las espiguillas presentan varios antecios con lemas 5-nervias con el dorso redondeado y ápice agudo o aristado, y las cariopsis presentan el hilo típicamente lineal. El número cromosómico básico es $\mathrm{x}=7 \mathrm{y}$ dotaciones cromosómicas entre $2 \mathrm{n}=14(2 \mathrm{x})$ y $2 \mathrm{n}=84(12 \mathrm{x})$ (Borrill et al. 1971).

Por sus caracteres morfológicos, el género Festuca ha sido dividido en varios subgéneros y secciones (Hackel 1882, Tzvelev 1971, Alexeev 1977, Clayton \& Renvoize 1986, Holub 1998, Catalán et al. 2007), principalmente sobre la base de las especies europeas. De los nueve subgéneros aceptados por Clayton \& Renvoize (1986), dos de ellos, Festuca y Helleria, se caracterizan por presentar hojas finas y por reunir el mayor número de especies, mientras que los subgéneros Drymanthele, Schedonorus, Subulatae, Subuliflorae, Obtusae, Hesperochloa y Xanthochloa presentan hojas anchas. Esta clasificación, con pocas variantes, es la más aceptada 
o difundida. Catalán et al. (2004) reconocen varias secciones dentro del subgénero Festuca (Festuca, Aulaxuper, Eskia, Dimorphae, Subbulbosae, Lajaconoa), mientras que Holub (1998) reconoce a nivel de género a Schedonorus P. Beauv., Drymochloa Holub y Leucopoa Griseb. Por otra parte, Lolium y Vulpia han sido considerados dentro de Festuca en el pasado, pero actualmente son tratados como géneros independientes en la mayoría de las floras.

Si bien la taxonomía del género Festuca es compleja, sus especies han sido ampliamente estudiadas, especialmente en el Viejo Mundo. Existen tratamientos taxonómicos diversos que pocas veces abarcan áreas geográficas extensas. El trabajo más importante es el de Hackel (1882) para las especies de Europa; también se pueden mencionar para este continente los tratamientos realizados por Kerguélen \& Plonka (1989) y Portal (1999), entre otros. Para las especies del continente asiático existen diversos estudios que tratan de esclarecer la taxonomía y tendencias evolutivas del género, aunque limitados geográficamente: Tzvelev (1971), Alexeev (1977, 1978, 1980, 1982). Para la región de Australia y Nueva Zelanda existe el tratamiento taxonómico publicado por Connor (1998). Para África se cuenta con los trabajos de Camus (1955), Clayton (1970) y Poilecot (1999). Dentro de los estudios para el Nuevo Mundo, para América del Norte y Mesoamérica se puede mencionar a Piper (1906, 1913), Hitchcock (1930, 1950), Alexeev (1980, 1981, 1982, 1983, 1984), Aiken et al. (1997), por citar los más importantes.

Para América del Sur, es muy importante el trabajo pionero de Saint-Yves (1927) para las especies de Festuca de Sudamérica, también son muy valiosos, aunque acotados en el área que abarcan, los trabajos de Hitchcock (1927), Parodi (1953), Türpe (1969), Nicora (1978), Matthei (1982), Alexeev (1984, 1986), Tovar (1972, 1993), Briceño \& Morillo (1994) y Renvoize (1998). Para los países del norte de América del Sur, son muy importantes las revisiones de Stančík (2003, 2004a, 2004b) y Stančík \& Peterson (2007). En el Catálogo de Plantas Vasculares del Cono Sur de Sudamérica, Zuloaga et al. (2008) citaron 56 especies y seis variedades para el género Festuca, sobre la base de los trabajos previos para la región. Recientemente, Catalán \& Müller (2012) destacaron la presencia de 46 especies y una variedad de Festuca para la flora de Argentina.

Si bien todos los trabajos mencionados constituyen importantes revisiones taxonómicas para las especies americanas del género Festuca de distribución austral, persisten dificultades en el reconocimiento de los taxones del Cono Sur. Muchas de las especies de este género presenta un amplio rango de variación morfológica, lo cual dificulta establecer caracteres diagnósticos, especialmente si se estudian para un área reducida. Es frecuente notar la ausencia de caracteres estables, haciendo que los límites específicos se superpongan. Se han sumado caracteres 
anatómicos de las láminas aunque, también éstos, son insuficientes o en muchos casos presentan ambigüedad en su definición.

La importancia de la anatomía foliar para el conocimiento sistemático de la familia Poaceae ha sido evidenciado en numerosos trabajos, como puede apreciarse en Metclafe (1960) y Ellis (1986). La anatomía foliar se utilizó como información diagnóstica en diferentes taxones, también para predecir la vía fotosintética de numerosas especies, y más tardíamente también se incorporó como información valiosa en análisis filogenéticos. En particular para el género Festuca, Hackel (1882) fue el primer autor en establecer el análisis anatómico de la lámina en corte transversal como herramienta para la identificación de especies. A partir de esto, la mayoría de los trabajos taxonómicos realizados en Festuca, tanto en especies del Nuevo y Viejo Mundo, incluyen análisis de anatomía y en algunos casos también de micromorfología epidérmica (Connor 1960; Badoux 1971; Aiken \& Darbyshire 1990; Aiken et al. 1994; Aiken \& Consaul 1995; Namaganda et al. 2009; Ortúñez \& de la Fuente 2010; Zarinkamar and Jouyandeh 2011; Ortúñez \& CanoRuiz 2013). A pesar de comprobarse que ciertos factores ambientales influyen fuertemente en algunos caracteres histofoliares (Kjellqvist 1961; Aiken \& Darbyshire 1985; Dube \& Morisset 1987; Aiken \& Consaul 1995), existe acuerdo entre los taxónomos que la anatomía foliar es un recurso necesario en el estudio de Festuca, en particular para las especies denominadas "hoja fina" ya que son más numerosas y para las cuales hay menos caracteres morfológicos diagnósticos. Cabe citar que para algunas zonas frías de Europa, un importante número de especies fueron caracterizadas únicamente por su estructura foliar anatómica (Namaganda et al. 2008), así de las 170 especies descritas para la Flora Europea, 150 se reconocen por la disposición del tejido esclerenquimático (Markgraf-Dannenberg 1980). Por ello, existe cierto consenso entre los especialistas de Festuca en considerar la anatomía para la diagnosis de las especies, y se la reconoce de mucha utilidad cuando se la combina con caracteres de otra naturaleza, tales como exomorfología de las inflorescencias, patrones de distribución geográfica, etc.

Las hipótesis filogenéticas propuestas para el género Festuca están enmarcadas en una serie de trabajos para toda la subtribu Loliinae con marcadores moleculares del cloroplasto, trnT-L y trnL-F, y del núcleo, ITS (Torrecilla \& Catalán 2002, Torrecilla et al. 2003, Catalán et al. 2004, 2007, Inda et al. 2008). Estos trabajos muestran a la subtribu Loliinae como monofilética, con la inclusión de los géneros Festuca, Vulpia, Lolium y varios géneros europeos pequeños o monotípicos (Psilurus, Ctenopsis De Not., Narduroides Rouy, Wangenheimia, Cutandia, Micropyrum, Castellia y Micropyropsis). De los géneros más grandes, Festuca sería parafilético, Vulpia polifilético y Lolium monofilético. En estos trabajos se recuperan dos linajes, uno de ellos con especies de hojas anchas, denominado broad-leaved y otro, más 
numeroso y de origen más reciente, que comprende, en su mayor parte, especies de hoja fina, llamado fine-leaved. Entre estos dos grandes linajes aparecen linajes menores que se ubican de manera ambigua, disminuyendo la resolución de los nodos basales de la subtribu. Por otra parte, Catalán et al. (2007) destacan que en ambos linajes principales de Loliinae (hoja ancha y hoja fina) se observa que los subgrupos basales están formados por diploides o poliploides de bajo número, mientras que los grupos más recientes presentan un aumento en la ploidía de sus especies.

El último trabajo publicado en filogenia de las Loliinae es el de Inda et al. (2008). A diferencia de los trabajos anteriores, en los que la mayor parte de las especies analizadas eran europeas y asiáticas, estos autores aumentan el muestreo con representantes de América, Nueva Zelanda y Asia del Este. Con el incremento de taxones provenientes de distintas áreas geográficas, ciertas relaciones filogenéticas se ven modificadas. Así, aparecen más clados con ubicación ambigua o en la base del linaje hojas finas, aparecen grupos monofiléticos con coherencia en la distribución geográfica de sus especies y también más conflicto entre particiones de datos. Además, se observa que algunas especies clasificadas en subgéneros caracterizados por presentar hojas anchas, aparecen emplazadas en clados dentro del linaje hoja fina, entre ellos especies sudamericanas como F. purpurascens Banks \& Sol. ex Hook. f. y F. cochabambana AE.B. Alexeev.

Todavía, las relaciones filogenéticas de las especies sudamericanas de Festuca han sido poco exploradas debido al bajo número de taxones muestreados. De las 220 especies sudamericanas de Festuca citadas por Stančík (2003), solo 18 especies están representadas en las filogenias publicadas para la subtribu. La incorporación de nuevos taxones podría cambiar la interpretación de la historia evolutiva de las Loliinae.

El estudio del género Festuca en América, y particularmente en Sudamérica, es fundamental para consolidar los estudios en la subtribu Loliinae. Es necesario saber cuantos taxones crecen en esta región, sus límites específicos y sus rangos de distribución geográfica. Para ello, es posible comenzar con un área más extensa que las abarcadas hasta la actualidad, como el Cono Sur de Sudamérica. Además, en el estado actual de conocimiento de la subtribu, se abren nuevos interrogantes: ¿cuáles son las características anatómicas que subyacen a los grupos hoja fina y hoja ancha?, ¿existe una relación entre factores ambientales y la anatomía?, ¿en cuántos linajes evolucionaron las especies sudamericanas de Festuca?, ¿responden las especies sudamericanas a patrones de distribución descriptos para otros linajes?, ¿cómo afectará la incorporación de más representantes americanos a la filogenia conocida de las Loliinae?. 


\section{HIPÓTESIS DEL TRABAJO}

1. Las especies de Festuca que crecen en el Cono Sur son menos que las descriptas en las floras de países o catálogos.

2. Los caracteres anatómicos y micromorfológicos foliares muestran patrones diagnósticos que permiten reconocer las especies de Festuca del Cono Sur.

3. Los patrones anatómicos y micromorfológicos foliares de las especies de Festuca del Cono Sur se asocian con diferentes niveles altitudinales de distribución geográfica.

4. Los términos "hoja fina" y "hoja ancha" utilizados frecuentemente en estudios taxonómicos y filogenéticos de Festuca, son lo suficientemente descriptivos para las especies del Cono Sur.

5. Las especies sudamericanas de Festuca pertenecen a más de un linaje de la subtribu Loliinae que colonizó este continente.

\section{OBJETIVOS DEL TRABAJO}

\section{Objetivos generales}

Realizar un tratamiento taxonómico de las especies del Cono Sur de América del Sur, para contribuir a la sistemática de la especies de Festuca de América del Sur y a la subtribu Loliinae; estudiar la morfología, micromorfología y anatomía foliar de las especies de Festuca del Cono Sur para describir y delimitar los taxones; incluir especies sudamericanas a la filogenia de la subtribu Loliinae para analizar los linajes que integran.

\section{$\underline{\text { Objetivos específicos }}$}

1. Realizar el tratamiento taxonómico de las especies de Festuca para el Cono Sur para definir límites precisos de sus taxones, actualizar la nomenclatura y la distribución geográfica de los mismos.

2. Resolver el complejo de especies relacionados a $F$. chrysophylla para delimitar los taxones afines por medio de caracteres morfológicos y anatómicos aplicando análisis estadísticos multivariados, sobre la base del estudio de material de herbario. 
3. Realizar un estudio morfo-anatómico detallado de las especies de Festuca del Cono Sur, estudiar la morfología externa de órganos vegetativos y reproductivos, estudiar la anatomía y micromorfología epidérmica foliar.

4. Evaluar la relación entre patrones anatómicos y micromorfológicos foliares y rangos de distribución altitudinal de las especies de Festuca del Cono Sur.

5. Ampliar el muestreo de especies sudamericanas de Festuca para la filogenia molecular de la subtribu Loliinae. Incorporar especies sudamericanas no muestreadas previamente y analizar sus relaciones filogenéticas con el resto de las especies y los linajes que integran.

Esta tesis está organizada en seis capítulos y dos apéndices. En el presente capítulo introductorio se plantean los antecedentes generales, objetivos e hipótesis que guiaron el trabajo. Luego, en cada capítulo se presentan los antecedentes particulares de cada tema tratado, los materiales y métodos específicos, resultados y discusión. En el Capítulo II se resuelve el complejo de especies del grupo "Festuca chrysophylla" por medio de un análisis estadístico, para luego incorporar esta especie ya resuelta al capítulo de taxonomía. En el Capítulo III se desarrolla el tratamiento taxonómico de las especies de Festuca que crecen en el Cono Sur de Sudamérica; este área fue delimitado de acuerdo al Catálogo de Plantas Vasculares del Cono Sur (Zuloaga et al. 2008), al final en este capítulo se ofrecen ilustraciones para la mayor parte de las especies tratadas. Luego, y ya establecidos los límites específicos para los taxones del Cono Sur, se analizó para cada especie la anatomía y la micromorfología foliar, detallada en el Capítulo IV, donde se describen e ilustran patrones anatómico-micromorfológicos, y se analizan de acuerdo a la distribución altitudinal de los taxones. En el Capítulo V se realiza un análisis filogenético de la subtribu Loliinae para el cual se obtuvieron secuencias nucleotídicas de Genbank y se incorporaron nuevas secuencias de especies que crecen en Sudamérica coleccionadas para este trabajo. En el Capítulo VI se contrastan las hipótesis planteadas y se detallan las conclusiones. Finalmente, se presenta un Apéndice I con el material de herbario examinado correspondiente a países del Cono Sur y, además, material adicional de otros países sudamericanos. En el Apéndice II se lista la bibliografía correspondiente a todos los capítulos de la tesis. 


\title{
CAPÍTULO II
}

\section{COMPLEJO DE ESPECIES: FESTUCA CHRYSOPHYLLA}

\begin{abstract}
ANTECEDENTES
Debido al amplio rango de variación morfológica que presentan los taxones de Festuca, la delimitación de las especies es dificultosa y la falta de caracteres morfológicos y anatómicos estables ha resultado en que diferentes autores usen distintos criterios para reconocer a las especies, o que, en un mismo tratamiento, los límites específicos frecuentemente se superpongan. Esto dificulta establecer caracteres diagnósticos para las especies del género, incluso para las especies de un área delimitada.
\end{abstract}

La aplicación de las técnicas numéricas multivariadas a complejos de especies o a taxones morfológicamente afines contribuye a reconocer grupos discretos de especímenes con mayor objetividad y a detectar los caracteres que permiten separarlos. Estas técnicas, sumadas al estudio detallado de los materiales tipo y descripciones originales, han sido ampliamente usadas para resolver grupos de especies conflictivas (Henderson 2005; Denham \& Aliscioni 2010; Escobar et al. 2011).

En el marco de la revisión del género Festuca para el Cono Sur, se detectó la necesidad de establecer límites precisos en el complejo Festuca chrysophylla. Este complejo constituye un grupo de taxones morfológicamente definido por láminas foliares de transcorte conduplicado, superficie adaxial densamente piloso-pubescente, con pelos que sobresalen por el margen foliar formando una línea blanquecina, la superficie abaxial es pilosa en la base y glabra hacia el ápice. Las láminas son hasta de $20 \mathrm{~cm}$ de largo, juncoides y rígidas, erectas a divergentes. Presentan panículas de (8)10-20 cm de largo, con ramas adpresas al raquis, las espiguillas presentan lemas pilosas a densamente pilosas en el margen y el ápice acuminado.

Este complejo incluye los siguientes taxones tratados como válidos: F. orthophylla Pilg., $F$. chrysophylla Phil. y F. eriostoma Hack. en Zuloaga et al. (2008) y los siguientes nombres tratados como sinónimos en la bibliografía más reciente: $F$. orthophylla var. boliviana Pilg., $F$. orthophylla var. glabrescens Pilg., F. orthophylla var. meyenii St.-Yves y F. deserticola var. juncea St.-Yves.

Los taxones de este complejo se distribuyen desde Perú y Bolivia, hasta el centro de Chile y Argentina. Habitan en suelos salinos, orillas de arroyos, vegas y laderas rocosas de la Puna y 
regiones andinas, entre 3200 y $4900 \mathrm{~m}$ de altitud. Constituyen importantes pajonales serranos (Stuckert 1906) y son importantes componentes de las provincias biogeográficas de la Puna y Altoandina, donde forman densas matas xerófilas bajas y punzantes (Cabrera 1957).

Türpe (1969) establece que en la Argentina habitan tres taxones de este complejo: Festuca orthophylla, F. eriostoma y F. chrysophylla. Sin embargo, esta autora separa a F. eriostoma de F. orthophylla por su porte menor, su lígula netamente biauriculada, láminas provistas de base callosa y el raquis y ramas de la inflorescencia glabros. Por otra parte, separa a $F$. chrysophylla de las demás por la pilosidad del ovario y la anatomía foliar (con haces semitrabados en $F$. chrysophylla y con al menos tres haces trabados en las restantes).

Tovar (1972) reconoce para la flora de Perú las dos variedades siguientes: F. orthophylla var. orthophylla y $F$. orthophylla var. glabrescens. Este autor diferencia la última variedad por sus lemas pubescentes solamente en los márgenes, las glumas menos pubescentes, por las ramas de la panícula glabras, la panícula más larga y las vainas glabrescentes. Este autor no mencionó a F. eriostoma ni a F. chrysophylla.

Matthei (1982) trata las especies de Festuca para Chile y cita a $F$. orthophylla y $F$. chrysophylla. Este autor las diferencia por la pilosidad de la lema (F. orthophylla presenta lemas pilosas y $F$. chrysophylla lemas glabras). Sin embargo, menciona que en ejemplares de $F$. chrysophylla la pilosidad de la lema puede ser variable y asemejarse a $F$. orthophylla. Según el mismo autor, ambas especies coinciden en sus caracteres anatómicos: presentan un contorno foliar redondeado o elíptico, haces trabados (1 ó 2 haces trabados abaxialmente) y epidermis abaxial con células cortas solitarias y presencia de células suberosas.

Renvoize (1998), para la flora de Bolivia, cita a F. eriostoma, F. chrysophylla y F. orthophylla. Considera que $F$. eriostoma podría sinonimizarse con $F$. orthophylla, ya que sólo se diferencia por su menor altura y láminas foliares patentes o deflexas. En la clave utiliza el color de las láminas para diferenciar a $F$. chrysophylla y $F$. orthophylla (anaranjadas vs. glaucas o verdosas, respectivamente).

Catalán \& Müller (2012) reconocen a $F$. orthophylla y a $F$. chrysophylla para la flora argentina e incluyen a $F$. eriostoma como sinónimo de $F$. orthophylla. Estos autores separan las dos especies válidas por el hábito $(F$. orthophylla como plantas cespitosas con cortos rizomas vs. $F$. chrysophylla como plantas cespitosas, sin rizomas), por la forma y anatomía de las láminas (hojas junciformes, de 1-1,2 mm de diámetro, con trabéculas completas de esclerénquima en nervios primarios y secundarios en $F$. orthophylla vs. hojas setáceas, de $0,6-0,7 \mathrm{~mm}$ de diámetro, con trabécula completa de esclerénquima únicamente en el nervio medio en $F$. 
chrysophylla) y por la pilosidad del ápice del ovario (glabro vs. esparcidamente piloso en $F$. chrysophylla).

A partir de lo anterior y sobre la base del estudio de las colecciones de herbario, nuestras observaciones permitieron detectar que (a) los caracteres usados por diferentes autores para la delimitación de las especies del complejo "Festuca chrysophylla" difieren entre sí y, en algunos casos, son ambiguos; (b) se encontraron ejemplares determinados bajo diferentes nombres por diferentes autores; (c) los datos sobre la distribución geográfica de los taxones son también imprecisos; y por lo tanto, (d) es necesario delimitar claramente las especies, esclarecer la taxonomía y documentar con mayor precisión la distribución geográfica.

El objetivo de este capítulo es delimitar las especies del complejo Festuca chrysophylla aplicando análisis estadísticos multivariados, sobre la base del estudio de material de herbario. Se circunscriben las especies, se proponen nuevos sinónimos y se actualizan los datos de distribución geográfica de acuerdo a los límites establecidos aquí.

\section{MATERIALES Y MÉTODOS}

\section{Estudio y selección del material de herbario}

Se consultaron los ejemplares tipo y ejemplares de la colección general de los herbarios BAA, BAB, CONC, LIL, LP, LPB, SI, SGO (Thiers 2015), y se observaron las imágenes digitales disponibles en línea en Jstor (www.jstore.org) y en los catálogos en línea de los herbarios.

Se revisaron 180 ejemplares. Para el análisis estadístico se seleccionados 100 especímenes completos que se determinaron como $F$. orthophylla (55 ejemplares), $F$. chrysophylla (25) y $F$. eriostoma (20). De los anteriores, 39 ejemplares se usaron para tomar datos anatómicos $(F$. orthophylla 20 ejemplares, F. chrysophylla 11, F. eriostoma 8).

Se registró cada ejemplar de acuerdo a la última determinación hallada en la cartulina y a los ejemplares sin determinar se les asignó un nombre de acuerdo a Türpe (1969) por incluir una clave para las tres especies válidas en Zuloaga et al. (2008).

El material estudiado para este capítulo se indica al final del mismo. Para este capítulo se estudiaron también ejemplares de Perú y Bolivia. 
Caracteres morfológicos y anatómicos de la lámina

Los caracteres usados en los análisis estadísticos (y su codificación) son: MORFOLÓGICOS. Continuos. Longitud de la panoja $(\mathrm{cm})$. Longitud del antecio basal $(\mathrm{mm})$. Longitud gluma inferior $(\mathrm{mm})$. Longitud gluma superior $(\mathrm{mm})$. Longitud lígula $(\mathrm{mm})$. Alto planta $(\mathrm{cm})$. Longitud lámina (cm). Discretos. Número de nudos en la zona de elongación: 1 (0), 2 (1). Ápice del ovario: glabro (0), con pelos (1). Ángulo de disposición de las láminas con respecto a la caña: menor de $45^{\circ}(0)$, mayor de $46^{\circ}(1)$.

ANATÓMICOS. Discretos. Número de haces vasculares primarios. Número de haces vasculares secundarios. Número de haces vasculares terciarios. Número de capas de células del anillo esclerenquimático. Doble-estado. Zona costal adaxial asociada solo a haces primarios (0), asociada a haces primarios y menores (1). Zona costal del haz central: redondeada (0), angular (1). Epidermis abaxial y esclerénquima: no diferenciadas (0), diferenciadas (1). Haz central adaxialmente: libre (0), trabado (1). Haz menor contiguo al central: libre (0), trabado (1). Haz primario contiguo al central: traba abaxial (0), traba adaxial (1). Haces menores asociados a: zona costal (0), zona intercostal (1). Pares sílico-suberosos: ausentes (0), presentes (1). Asperezas o aguijones en superficie abaxial: ausentes (0), presentes (1).

Otros caracteres estudiados pero que no presentaron variación fueron eliminados previamente del análisis. Entre los caracteres aquí analizados se encuentran los caracteres diagnósticos para la identificación de taxones en los trabajos taxonómicos previos para Argentina y Chile, y en lo posible, se incluyeron los ejemplares citados en estos mismos tratamientos, con el fin de representar el criterio taxonómico de los autores.

Los caracteres morfológicos de vaina y lámina se tomaron de la tercera o penúltima hoja de macollos estéril. Para los restantes caracteres se usó la estructura que reflejara la mayor expresión del atributo en cada ejemplar; así, la caña florífera más larga, la espiguilla con mayor número de antecios o la lígula de mayor longitud.

Para la observación de rasgos anatómicos se utilizó el tercio medio de una lámina desarrollada de una innovación estéril. El material se hidrató con amoníaco (NH3) y agua destilada por $48 \mathrm{~h}$ a temperatura ambiente y se fijó en GALA (glicerina, alcohol y ácido acético) por 24 horas (Ruzin 1999). Se realizaron cortes transversales a mano alzada, los cuales se decoloraron con hipoclorito de sodio diluido al 50\%, se lavaron con agua destilada y se tiñeron con safranina. Para los preparados de epidermis adaxial y abaxial en vista topográfica, se siguió la técnica propuesta por Metcalfe (1960). Los preparados fueron montados en gelatina-glicerina. Para la descripción de caracteres anatómicos se siguió la terminología propuesta por Ellis $(1976,1979)$. 
Análisis estadístico

El análisis de datos se llevó a cabo mediante la aplicación de métodos multivariados: análisis de conglomerados (AC) y análisis de coordenadas principales (ACop); ya que ambos permiten el uso de variables cualitativas y cuantitativas (Balzarini et al. 2008). Se usó el software estadístico Infostat ver. 2011 (Di Rienzo et al. 2011).

Se definieron los 23 caracteres como variables (10 morfológicos y 13 anatómicos). Se construyó una matriz sobre la base de 100 ejemplares y 10 caracteres morfológicos y otra matriz sobre la base de 39 ejemplares para 23 caracteres anatómicos y morfológicos.

Para la matriz basada en datos morfológicos se realizó el análisis de conglomerados con el algoritmo UPGMA (Unweighted Pair Group Method with Arithmetic Mean), utilizando el coeficiente de distancia Gower (Gower 1971). Se calculó el coeficiente de correlación cofenético (r). Posteriormente, se aplicó el ACoP utilizando el coeficiente de correlación de Pearson. Los datos fueron estandarizados sustrayendo de cada observación la media y dividiendo el resultado por la desviación estándar. Para la matriz basada en datos anatómicos y morfológicos se aplicó el ACoP siguiendo los pasos anteriormente descriptos para datos morfológicos.

\section{$\underline{\text { Aspectos nomenclaturales }}$}

Se estudiaron los ejemplares tipo de todos los sinónimos citados por Darbyshire et al. (2003) y en Zuloaga et al. (2008) a través de la observación directa del ejemplar o de fotos digitales de alta calidad. Se recopilaron todas las descripciones originales. Se compararon cada uno de los materiales tipo y/o sus descripciones originales con los datos de variación morfológica establecidos para F. chrysophylla con el fin de corroborar las sinonimias.

\section{RESULTADOS Y DISCUSIÓN}

\section{$\underline{\text { Análisis estadístico }}$}

Los análisis estadísticos mostraron que los atributos morfológicos y anatómicos analizados reúnen ejemplares de $F$. chrysophylla, F. eriostoma y $F$. orthophylla sin discernimiento de grupos que se correspondan con alguna de las entidades taxonómicas (Fig. 1). Esto sugiere 
similitud entre los atributos de estos taxones, lo cual fue señalado en otros trabajos (Türpe 1969; Renvoize 1998; Catalán \& Müller 2012).

El análisis de conglomerados (Fig. 1A) muestra que los ejemplares de las tres especies se reúnen en grupos heterogéneos y no muestran un patrón que coincida con las especies estudiadas. El fenograma (índice de correlación cofenético $=0.77$ que indica una buena representación de la matriz de distancia) muestra dos grandes conglomerados separados a distancia 0.53 que reflejan la semejanza entre las tres unidades taxonómicas. Estos grupos se caracterizan por reunir ejemplares de los tres taxones, inclusive, en los subgrupos y divisiones más finas del fenograma.

El análisis de coordenadas principales con datos morfológicos de 100 especímenes (Fig. 1B) muestra que los ejemplares se distribuyen aleatoriamente en el espacio bidimensional. Los grupos apenas definidos que podrían observarse están constituidos por especímenes de los tres taxones. El análisis con datos anatómicos y morfológicos de 39 especímenes (Fig. 1C) muestra el mismo resultado, indicando que las características anatómicas tampoco permiten separar a las entidades estudiadas.

\section{Caracteres morfológicos}

Se observó que los caracteres morfológicos usados por autores previos para distinguir entre los taxones de este complejo son, en algunos casos, difíciles de definir y en otros son muy variables.

El alto de la planta fue empleado por Türpe (1969) y por Renvoize (1998) para separar a $F$. eriostoma (hasta 20 o $30 \mathrm{~cm}$ de alto) de F. orthophylla (mayor de 20 o $30 \mathrm{~cm}$ de alto). Sin embargo, se observó que este carácter es variable en ejemplares de un mismo taxón y forma un continuo en el total de ejemplares analizados. Esta característica también es variable si se considera el ambiente donde crece la planta. Así se observó que en ambientes más hostiles, con mayor permanencia de nieve en el tiempo, las plantas suelen tener un porte menor. Lo mismo sucede con el largo de la panícula.

El carácter de rizoma corto o ausente usado por Catalán \& Müller (2012) es, al menos difícil de establecer en todos los ejemplares, aunque se cuente con ejemplares completos. Todos los ejemplares observados son perennes, cespitosos, a veces con un rizoma muy corto o apenas desarrollado que permite matas más flojas, pero no observamos un punto que permita delimitar 
dos estados para este carácter. Por otra parte, el carácter de color de las láminas no pudo ser registrado en el material de herbario con precisión.

Los caracteres de la pubescencia de las láminas y las lemas no fueron usados en los análisis estadísticos por no presentar variabilidad en los ejemplares analizados. Finalmente, éstos son los caracteres que definen a la especie Festuca chrysophylla.
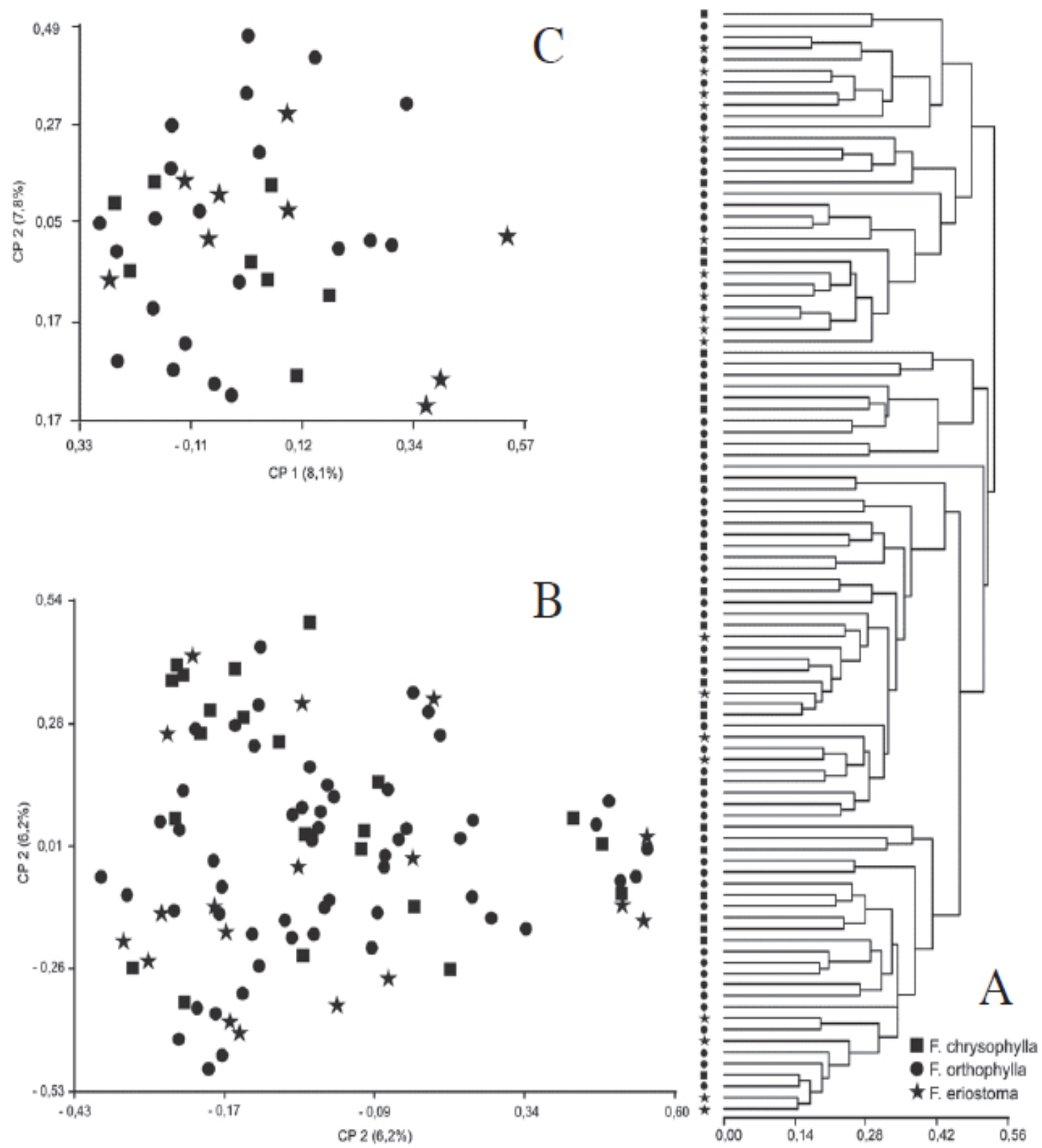

Figura 1. Análisis estadísticos multivariados. A, análisis de conglomerados (AC), fenograma basado en 100 ejemplares y datos morfológicos. B, análisis de coordenadas principales (ACop), proyección de 100 ejemplares basado en datos morfológicos. C, análisis de coordenadas principales (ACop), proyección de 39 ejemplares basado en datos morfológicos y anatómicos. 
Caracteres anatómicos

En cuanto a la anatomía, se observó que todos los ejemplares analizados del complejo "Festuca chrysophylla" presentan transcorte plegado, conduplicado, con un anillo continuo de esclerénquima subepidérmico en la cara abaxial, también observados por otros autores (Türpe 1969, Matthei 1982; Catalán \& Müller 2012). En relación a los haces vasculares y la presencia de trabas esclerenquimáticas adaxiales y abaxiales, se observó que existe variación y no se correlacionan a lo establecido por Türpe (1969), Matthei (1982) y Catalán \& Müller (2012) para diferenciar los taxones de este complejo.

Las láminas constan de 3 a 5 haces vasculares primarios que alternan con haces menores, el haz primario central presenta generalmente trabas esclerenquimáticas adaxial y abaxial, excepto algunos ejemplares como Peterson, P. M. 12808 y Ayala, F. 4 que sólo presentan traba abaxial.

Los haces primarios contiguos al central pueden variar en cuanto al desarrollo de las trabas esclerenquimáticas: pueden presentarse igual al haz primario central, es decir con trabas adaxial y abaxial, al menos uno de ellos, como por ejemplo Percy 7627 (F. orthophylla), Cabrera, A. L. 30528 (F. eriostoma) y Zuloaga, F. O. 9180 (F. crysophylla); o solamente con traba esclerenquimática abaxial como en Cabrera, A. L. 32486 (F. orthophylla); muy raramente pueden ser haces libres o sólo con trabas adaxiales como en Beck, St. 23694 (F. orthophylla). Corroboramos así que, al analizar un número considerable de especimenes, los caracteres usados por otros autores como diagnósticos no se mantienen estables dentro de las especies consideradas en el complejo.

\section{Sistemática}

De acuerdo a los resultados de los análisis estadísticos se concluye que no hay caracteres morfológicos o anatómicos que permitan separar los ejemplares estudiados que corresponden a la morfología del complejo "Festuca chrysophylla". Por lo tanto se consideran los siguientes taxones como sinónimos de Festuca chrysophylla: F. orthophylla, F. eriostoma, F. orthophylla var. boliviana , F. orthophylla var. glabrescens, F. orthophylla var. meyenii y F. deserticola var. juncea. Festuca orthophylla es un nuevo sinónimo de F. chrysophylla, establecido en este trabajo.

Los ejemplares tipo y protólogos de F. eriostoma, F. orthophylla var. boliviana, F. orthophylla var. glabrescens, F. orthophylla var. meyenii y F.deserticola var. juncea fueron estudiados y se 
confirma su correspondencia con la morfología de F. chrysophylla, tal como se describe en esta tesis (ver capítulo III, Tratamiento taxonómico).

Los caracteres que permiten reconocer a Festuca chrysophylla de las especies del género Festuca son: láminas con la superficie adaxial densamente pilosa, con pelos que sobresalen entre los márgenes y forman una línea blanca desde la base hasta la parte media de la lámina; y lemas con los márgenes densamente pilosos.

Festuca chrysophylla se distribuye en Argentina, Chile, Bolivia y Perú, entre 3200-4900 m de altitud. Crece a lo largo de la Cordillera de los Andes y habita en ambientes xerofíticos, suelos salinos, orillas de arroyos, vegas y laderas rocosas. En las provincias biogeográficas Altoandina, Puna y del Desierto.

\section{MATERIAL DE HERBARIO ESTUDIADO}

Los ejemplares indicados con $*$ se estudiaron con anatomía: ARGENTINA. Catamarca: Departamento Antofagasta de la Sierra, Ruta 53, falda de La Ciénaga, 19 febrero 1980, Cabrera, A. L. et al. 31849* (SI); Belén, Laguna Blanca, 3200 m, 1 abril 1982, Gómez Kapla 69 (SI); 1 agosto 1981, Gómez Kapla 92* (SI); Reserva de la Biosfera Laguna Blanca, 4200 m, 16 marzo 1989, Recca, A. R. et al. 143 (SI); 3800 m, 16 marzo 1989, Recca, A. R. et al. 41 (SI); 3150 m, 21 marzo 1989, Recca, A. R. et al. 161 (SI); 3800 m, 16 noviembre 1989, Recca, A. R. et al. 40 (SI); 3200 m. 15 marzo 1989. Recca, A. R. et al. 52 (SI); 3600 m. 21 marzo 1989. Recca, A. R. et al. 169 (SI); 3750 m, 20 marzo 1989, Recca, A. R. et al. 196 (SI); vega cerca de Gendarmería Laguna Blanca, 3200-3300 m, 17 marzo 1989, Recca, A. R. et al. 1 (SI); Ruta Prov. 43, entre villa Vil y Antofagasta de la Sierra, a $39 \mathrm{~km}$ de la primera, Quebrada de Randolfo, 3212 m, 25 abril 2006, Biurrun, F. et al. 8297* (SI); dejando la Ruta Prov. 43 entre Villa Vil y Antofagasta de la Sierra, a $20 \mathrm{~km}$ del cruce con ésta, Laguna Blanca, $3290 \mathrm{~m}, 26$ abril 2006, Biurrun, F. 8319 (SI); Laguna Blanca. 24 febrero 1981, Cabrera, A. L. et al. 32486* (SI); camino a Antofagasta, Pasto Ventura, 26 febrero 1981, Cabrera, A. L. et al. 32548 (SI); cerca de Gendarmería, 3200-3300 m, 14 marzo 1984, Recca, A. R. et al. 25 (SI); Cuesta de Randolfo, 3400 m, 23 marzo 1981, Cabrera, A. L. et al. 32462 (SI); Santa María, Cerro Aconquija, 4500 m, 15 abril 1917, Jörgensen, P. 1721 (SI); Tinogasta, Po. San Francisco, La Coipa, Rincón, 3600 m, 7 febrero 1995, Ruthsatz, B. 9253* (SI). Jujuy: Departamento Cochinoca, Abra Pampa, Cerro Huancar, 23 enero 1948, Cabrera, A. L. 9425 (SI); Sierra de Quichagua, 3940 m, 26 marzo 2006, Peterson, P. M. et al. 19559 (SI); Casa linda, peñas inmediaciones (al SE) del pueblo, ojo de agua, 23 diciembre 1980, Ana, C. 2298 (SI); Abra Pampa, estación experimental del INTA, 3470 m, 15 marzo 1978, Arenas, P. et al. s. n. (SI); 
Abra Pampa, Cerro Huancar, 3500 m, 17 febrero 1963, Cabrera, A. L. 15273 (SI); Abra Pampa, Cerro Huancar, 20 enero 1976, Cabrera, A. L. et al. 27401 (SI); Abra de la Pampa, 20 enero 1976, Cabrera, A. L. et al. 29401 (SI); El Carmen, Abra de Lipán, 4100 m, 26 marzo 1992, Cabrera, A. L. et al. 34841 (SI); Humahuaca, Mina Aguilar, 4600 m, 15 enero 1948, Cabrera, A. L. 9261 (SI); Mina Aguilar, 4500 m, 11 enero 1968, Cabrera, A. L. et al. 18975 (SI); Cerro Aguilar, 4400 m, 25 febrero 1953. Hunziker, A. T. et al. 6214 (SI); Camino a Palca de Aparzo, a $28 \mathrm{~km}$ de Humahuaca, 4200 m, 26 febrero 1983, Hunziker, A. T. et al. 10422 (SI), Sierra del Aguila, 4000 m, 03 noviembre 1929, Venturi 8734 (SI); entre Palca de Aparzo y Sta. Ana, 3870 m, 11 febrero 2007, Zuloaga, F. O. et al. 9180* (SI); Rinconada, Minas Pirquitas, 23 febrero 1980, Arenas, P. 1853 (SI); Laguna de Pozuelos, 3690 m, 12 febrero 1995, Deginani, N. et al. 611 (SI); 67 km al S de Mina Pirquitas, Laguna de Vilama, 4530 m. 14 febrero 1999, Morrone O. et al. 2555 (SI); Pan de Azúcar, 3 marzo 1966, de la Sota 4220 (SI); Santa Catalina, Firtz Claren 11615 (SI); Susques, Campo Amarillo, 16 febrero 1980, Cabrera, A. L. et al. 31789 (SI); N of Susques, ENE Paso de Jama, SE of Cerro Tocol, 4132 m, 26 marzo 2006, Peterson, P. M. et al. 19547 (SI); Paso de Jama, límite con Chile, 4250 m, 23 febrero 2009, Zuloaga, F. O. et al. 11143* (SI); Tumbaya, Abra de Lipán, 4000 m. 24 marzo 1979, Cabrera, A. L. et al. 30528* (SI); subida al Abra de Lipán, 3800 m, 15 febrero 1980, Cabrera, A. L. et al. 31676 (SI); camino de Purmamarca al Abra de Lipán, Abra Blanca, 3900 m, 17 febrero 1985, Kiesling, R. 5307 (SI); Alto del Morado, entre Purmamarca y Tres Morros, 4175 m, 18 febrero 2008, Zuloaga, F. O. et al. 10200 (SI); Abra de Lipán, 4200 m, 17 enero 1988, Zuloaga, F. O. et al. 3558 (SI); Valle Grande, Caspalá, cumbres a 4400 m, comienzo del declive occidental, 3 marzo 1940, Burkart, A. et al. 11825* (SI); Yavi, Abra de Lizoite, 4450 m, 1 marzo 1970, Fabris, H. A. 7778* (SI); sin consignar, Cerca del Abra Yampaite, camino a Casa Linda, 18 enero 1948, Cabrera, A. L. 9308 (SI). La Rioja: Departamento General Belgrano, Sierra de Famatina, Mina La Mejicana, 4000 m, 03 febrero 1995, Ruthsatz, B. 9138* (SI); Mina La Mejicana, Cueva de Pérez, 3850 m, 20 abril 1995, Biurrun, F. 4139 (SI); entre Los Corrales y Cueva de Pérez, 3800 m, 13 enero 1976, Cabrera, A. L. et al. 27178* (SI); entre Los Corrales y Cueva de Pérez, 3500 m. 13 enero 1976, Cabrera, A. L. et al. 27204 (SI); Cueva de Pérez, Sierra de Famatina, 4200 m, 15 enero 1947, Hunziker, A. T. et al. 1943 (SI). Prov. Salta, Departamento Los Andes, San Antonio, Alto de Chorrillos, 14560 m, 27 enero 1949, Cabrera, A. L. 122 (SI); hwy $51 \mathrm{~W}$ of San Antonio de los Cobres, just S of pass to Jujuy, $4301 \mathrm{~m}, 25$ marzo 2006, Peterson, P. M. et al. 19545 (SI); ruta 51, de San Antonio de los Cobres a Viaducto La Polvorilla, 4170 m, 18 febrero 2002, Cialdella, A. M. et al. 419 (SI); ruta 51, 8 km después del desvío a Santa Rosa de Los Pastos Grandes, 4410 m, 18 febrero 2002, Cialdella, A. M. et al. 431 (SI); ruta 51, Alto Chorrillo, 4530 m, 24 febrero 2009, Zuloaga, F. O. et al. 11179* (SI); desvío de la ruta 51 hacia viaducto La Polvorilla, 3950 m, 13 febrero 2007. Zuloaga, F.O. et al. 9310* (SI); Rosario de La Frontera, Laguna Seca, cerro del Cajón, 4200 m, 15 febrero 1914, Rodríguez 1351 (a) (SI); 
Santa Victoria, ruta Prov. 145 de El Cóndor a Nazareno, Abra del Cóndor, 4500 m, 16 febrero 2009, Zuloaga, F. O. et al. 10802 (SI); departamento sin consignar, Quebrada de Paizaite, 3500 m, 2 febrero 1943, Meyer, T. 4899 (SI). Tucumán: Departamento Tafí del Valle, cumbres Calchaquíes, 4300 m, 14 marzo 1984, Gómez-Sosa et al. 182* (SI); El Pelao, 15 marzo 1912, Rodríguez 425* (SI); cumbre Calchaquí, 4400 m, 30 enero 1933, Parodi, L. R. 10832 (SI).

BOLIVIA. La Paz: Provincia Aroma, South of La Paz on Hwy 1 towards Oruro, 6,7 km of Villa Loza on road to Urmiri and Spahaqui, 4040 m, 4 marzo 1993, Peterson, P. M. et al. 12626* (SI); Camacho, Puerto Acosta, 4 km hacia La Paz, 3860 m, 6 abril 1982. Beck, St. 7663* (SI); Los Andes, 1 km NW from Tambillo, 3750 m, 31 marzo 1981, Renvoize, S. A. et al. 4128* (SI); Ingavi, alrededores de Viacha, 3900 m, 1 febrero 1979, Ceballos et al. 110 (SI). Oruro: Cercado, sistema de dunas a la salida de la ciudad, 3800 m, 1 febrero 1979, Ceballos et al. 205 (SI); Saucarí, comunidad Kollpuma, 60 km al SW de Oruro, 3712 m, 12 febrero 1992, Ayala, F. 4* (SI). Potosí: Linares, al norte de Cucho Ingenio, 4185 m, 6 abril 1997, Cocucci, A. A. et al. 845 (SI); Quijarro, $14 \mathrm{~m} \mathrm{~S}$ of Severuyo on road towards Uyuni, 3630 m, 9 marzo 1993, Peterson, P. M. et al. 12797* (SI); Sud Lípez, Cerro Tapaquilcha, 4600 m, 11 abril 1980, Liberman, M. 168* (SI); región de Laguna Colorada, lomas de Toloncejara, 4870 m, 20 abril 1991, Navarro, G. 420* (SI); región de Laguna Colorada, laderas orientales del Cerro Negro, 4450 m, 24 abril 1991, Navarro, G. 476* (SI); región de Laguna Colorada, Cerro Pabellón, 4860 m, 18 abril 1990, Navarro, G. 479 (SI); N of Río Mulatos on road towards Challapata, 3650 m, 10 marzo 1993, Peterson, P. M. et al. 12808* (SI); Tomás Frias, Khare-Khare, arriba de la fundición de Karachipampa, 4400 m, 13 marzo 1988, Schultes, R. E. 175 (SI). Tarijá: José María Avilés, Arenales, cerca de Copacabana, 3750 m, 6 marzo 1998, Beck, St. 23694* (SI).

CHILE. II. Región: Provincia Antofagasta, 4680 m, 22 marzo 2001. Peterson, P. M. et al. 15602 (SI); km 31,5 East from San Pedro de Atacama on paved HWY towards Argentine border at Paso de Jama, 3985 m, 16 marzo 2001, Peterson, P. M. et al. 15508* (SI); km 33,5 East from San Pedro de Atacama on paved HWY towards Argentine border at Paso de Jama, 4120 m, 16 marzo 2001, Peterson, P. M. et al. 15510* (SI); km 43 on road from San Pedro to Paso Jama road, then south 1,5 km on Cerro Toto or Chascon de Purico, $4740 \mathrm{~m}, 16$ marzo 2001, Peterson, P. M. et al. 15521* (SI); Cuesta de Chita on road from Capana to el Tatio, km 34, 3995 m, 19 marzo 2001, Peterson, P. M. et al. 15568* (SI); sin localidad consignada, 4400 m, 17 marzo 2001, Peterson, P. M. et al. 15535 (SI); $6 \mathrm{~km}$ south of El Tatio "Hotel" at km 80 on road north from San Pedro de Atacama to El Tatio, 4396 m, 19 marzo 2001, Peterson, P. M. et al. 15570* (SI); El Loa, San Pedro de Atacama, Mountaraqui, vega Zorras, 4250 m, 14 marzo 1992, Ruthsatz, B. 8243* (SI). XV Región: $22 \mathrm{~km}$ E of Zapahuira at Portezuelo Chapiquiña, 4460 m, 2 abril 2001, Peterson, P. M. et al. 15731 (SI); 22 km E of Zapahuira at Portezuelo 
Chapiquiña, 4460 m, 2 abril 2001, Peterson, P. M. et al. 15732 (SI); Las Cuevas, 4400 m, 5 mayo 1977, Escobar 118 (SI); termas Chiriguaya, 4480 m, 5 abril 2001, Peterson, P. M. et al. 15767* (SI); Parinacota, Volcán Tacora, Chislluma, 4500 m, 1 abril 1926, Werdermann, E. 1161* (SI); $133 \mathrm{~km} \mathrm{E} \mathrm{of} \mathrm{Arica} \mathrm{at} \mathrm{Termas} \mathrm{Jurasi} \mathrm{above} \mathrm{Putre,} \mathrm{4040-4150} \mathrm{m,} 3$ abril 2001, Peterson, P. M. et al. 15748 (SI); $133 \mathrm{~km}$ E of Arica at Termas Jurasi above Putre, 4040-4150 m, 3 abril 2001, Peterson, P. M. et al. 15745* (SI), $3 \mathrm{~km} \mathrm{~N}$ of Parinacota, 4 abril 2001, Peterson, P. M. et al. 15755 (SI); sur de Laguna Chungara, 4750 m, 31 marzo 1992, Ruthsatz, B. 8437 (SI); $15 \mathrm{~km}$ E of Zpahuira on road towards Guallatiri, $4156 \mathrm{~m}, 1$ abril 2010, Peterson, P. M. et al. 15713 (SI); $26 \mathrm{~km}$ E of Zapahuira on top of Cerro Champiquiña, $4810 \mathrm{~m}, 1$ abril 2001, Peterson, P. M. et al. 15723 (SI). Región de Tarapacá, Prov. Tamarugal, 82 km NE of Huara on HWY A-55 towards Colchane, 3890 m, 25 marzo 2001, Peterson, P. M. et al. 15630 (SI); $92 \mathrm{~km} \mathrm{NE}$ of Huara on road towards Colchane, 4600-4830 m, 26 marzo 2001, Peterson, $P$. M. et al. 15633 (SI); $110 \mathrm{~km} \mathrm{NE}$ of Huara on road towards Colchane, 4120 m, 27 marzo 2001, Peterson, P. M. et al. 15662* (SI); $110 \mathrm{~km}$ of Huara on road towards Colchane, $4210 \mathrm{~m}, 27$ marzo 2001, Peterson, P. M. et al. 15660 (SI); $66 \mathrm{~km} \mathrm{NW}$ of Colchane on road towards Chilcayo at Porto Capitán, just E of Cerro Capitán, 4464 m, 28 marzo 2001, Peterson, P. M. et al. 15674* (SI); Cordillera y Co. Columtusca, Apacheta, 4600 m, 1 marzo 1926, Werdermann, E. 1072* (SI); $94 \mathrm{~km} \mathrm{NE} \mathrm{of} \mathrm{Huara} \mathrm{on} \mathrm{road} \mathrm{towards} \mathrm{Colchane,} 4078 \mathrm{~m}, 26$ marzo 2001, Peterson, P. M. et al. 15637 (SI).

PERÚ. Cusco Espinar Chisiccata, Yauri. 4000 m, 28 marzo 1987, Nuñez, P. 7627* (SI). 


\title{
CAPÍTULO III
}

TRATAMIENTO TAXONÓMICO DEL GÉNERO FESTUCA PARA EL CONO SUR

\begin{abstract}
ANTECEDENTES
El género Festuca está representado aproximadamente por 450-500 especies que se distribuyen en las regiones templadas de todo el mundo y también se extienden sobre las cimas de las montañas en los trópicos (Clayton \& Renvoize 1986; Darbyshire et al. 2003). Para el continente americano, Darbyshire et al. (2003) citaron 45 especies para América del Norte y 140 especies para los Andes sudamericanos.
\end{abstract}

Stančík (2003) consideró que América del Sur es un centro importante de diversidad del género Festuca, con aproximadamente 220 taxones que se encuentran concentrados en la zona altoandina, con un enclave extra-andino en el SE de Brasil y NE de Argentina.

Stančík \& Peterson (2007) mencionan que las especies de Festuca se distribuyen de manera heterogénea en América del Sur y que la concentración más alta de especies se encuentra entre el centro de Perú y el norte de Argentina (casi el 50\% de los taxones), mientras que el norte de los Andes, el Ecuador central (Pichincha con 14 especies y Chimborazo con 13 especies) y el norte de Colombia (Boyacá con 14 especies) son algunas de las áreas con alta diversidad de especies.

El área de estudio comprendido en esta tesis es la región geográfica denominada "Cono Sur" por Zuloaga et al. (2008). Abarca el extremo sur de Sudamérica, entre $17^{\circ} 30^{\prime}-56^{\circ} 30^{\prime} \mathrm{S}$ y $48^{\circ}-$ $75^{\circ} \mathrm{O}$, e incluye los territorios de Argentina, sur de Brasil (estados de Paraná, Santa Catarina y Río Grande do Sul), Chile, Paraguay y Uruguay. Representa el 26\% de la superficie total del continente. En el Catálogo de Plantas Vasculares del Cono Sur (Zuloaga et al. 2008) se citan 56 especies y seis variedades para el género Festuca.

Existen diversos trabajos taxonómicos que tratan a las especies de Festuca de Sudamérica. Así, la primera contribución importante para festucas del Nuevo Mundo fue realizada por Saint-Yves (1927), quien describe numerosas nuevas especies y variedades e incluye una caracterización anatómica para cada taxón. Las especies de Festuca en Perú fueron estudiadas por Tovar (1972) quien reconoció 37 taxones. En la revisión de las gramíneas de Bolivia, Renvoize (1998) reconoció 28 taxones del género Festuca. Finalmente, Stančík \& Peterson (2007) revisan el género Festuca para los páramos de Sudamérica. 
Con respecto al área de estudio, también hay revisiones taxonómicas disponibles para países del Cono Sur. Matthei (1982) estudió el género Festuca y reconoció 28 especies para Chile. Para el territorio argentino, Parodi (1953) registró 16 especies de Festuca y Nicora (1978) reconoció 18 para la región de la Patagonia; asimismo, Türpe (1969) estudió las especies de Festuca en Argentina (excluyendo la Patagonia) y registró 32 taxones; recientemente, Catalán \& Müller (2012) destacaron la presencia de 46 especies y una sola variedad de Festuca para la flora de Argentina; Rúgolo et al. (2008) solamente citaron a F. fimbriata para la flora de Paraguay. Por último, Darbyshire et al. (2003) y Stančík \& Peterson (2007) han citado las especies $F$. fimbriata, F. ulochaeta y F. arundinacea para Uruguay y el sur de Brasil.

Por otra parte, numerosas clasificaciones infragenéricas propuestas para Festuca s.l. han sido establecidas a partir de características morfológicas y anatómicas de la lámina foliar (Hackel 1882; Piper 1906; Alexeev 1977, 1978, 1980, 1986). Sin embargo, la clasificación actualmente adoptada por la mayoría de agrostólogos, es la propuesta por Clayton \& Renvoize (1986). Más recientemente, Stančík (2003) presentó una clasificación infragenérica del género Festuca para América del Sur, con 14 subgéneros y 30 secciones; este trabajo estuvo enfocado a las especies que se distribuyen en Colombia y, por lo tanto, no representa una clasificación infragenérica abarcativa. Catalán et al. (2007) proponen una clasificación taxonómica dentro la subtribu Loliinae basada en uno de los posibles escenarios que plantean los análisis filogenéticos, pero en este estudio no están bien representadas las especies del hemisferio sur.

$\mathrm{Si}$ bien estos trabajos constituyen importantes revisiones para las especies americanas del género Festuca de distribución austral, persisten dificultades en el reconocimiento de los taxones del Cono Sur debido al amplio rango de variación morfológica que presentan los taxones. Los caracteres anatómicos de las láminas fueron tradicionalmente usados para colaborar en la delimitación de los taxones, aunque también son caracteres insuficientes o en muchos casos presentan ambigüedad en su definición.

La falta de caracteres morfológicos y anatómicos estables dificulta determinar caracteres diagnósticos para las especies del género Festuca, inclusive para las especies de un área restringida. Como resultado, se observa que diferentes autores usan distintos criterios morfoantómicos para reconocer a las especies, o que, en un mismo tratamiento, los límites específicos frecuentemente se superponen. Como consecuencia de la falta de límites específicos claros para las especies sudamericanas, tampoco es posible definir con precisión la distribución geográfica de los taxones.

En este capítulo se establecen límites específicos para las especies de Festuca que crecen en el Cono Sur sobre la base de sus caracteres morfológicos, se actualiza la taxonomía, se resuelven 
problemas nomenclaturales y se establecen los rangos de distribución geogáfica para cada una de las especies.

\section{MATERIALES Y MÉTODOS}

\section{Bibliografía consultada}

Se realizó una revisión exhaustiva del material bibliográfico relacionado con la diversidad y taxonomía del género (catálogos, floras, tratamientos taxonómicos parciales). Se estudiaron las descripciones originales de todos los nombres citados en este tratamiento (nombres correctos y sinónimos). Se utilizó la Biblioteca del Instituto de Botánica Darwinion y bibliografía "on-line" (www.botanicus.org y www.biodiversitylibrary.org).

\section{Material de herbario consultado}

Se realizaron viajes de colección a Chile (VII región, Chillán) y Argentina (Patagonia, Cuyo y NOA) para estudiar las plantas en su hábitat. Se observaron caracteres vegetativos y reproductivos, se tomaron fotos y datos del ambiente. Por medio de visitas personales se estudiaron los ejemplares tipo y la colección general depositados en los siguientes herbarios: BA, BAB, COL, CONC, CORD, CUZ, HUA, HSB, HUSA, LIL, LP, LPB, MOL, QCNE, QPLS, SGO, SI, USM, VEN, y Z abreviados según Thiers et al. (2015).

Se estudiaron ejemplares tipo en los herbarios visitados personalmente y también se procedió a la búsqueda y al reconocimiento de ejemplares tipo en bases de datos "on-line". Para lo anterior, se recurrió a Jstor (www.jstore.es) con acceso proporcionado por el Consejo Nacional de Investigaciones Científicas y Técnicas (CONICET) y los catálogos en línea de los siguientes herbarios: B, BM, BR, CAS, E, F, G, GH, HAL, JE, K, LE, MO NY, P, PR S, US, W, WELT.

Se estudiaron aproximadamente 1100 ejemplares de herbario de todas las especies. Se confeccionó una base de datos donde se registró cada ejemplar. El material de herbario estudiado se muestra en el Apéndice I. Se confeccionó un banco de imágenes digitales con los ejemplares tipo y los protólogos correspondientes. 
Aspectos nomenclaturales

Los nombres de las especies aceptados para el Cono Sur se presentan en negrita y los sinónimos en cursiva. Se citan sinónimos solamente para América del Sur. Para facilitar la lectura, los autores de las especies se citan en el tratamiento taxonómico aunque se mencionen con anterioridad en este texto.

Se siguió el Código Internacional de Nomenclatura para Algas, Hongos y Plantas (Código de Melbourne, McNeill et al. 2012), en sus versiones inglés y español. También se siguieron las recomendaciones de Turland (2013). Se siguió a McNeill (2014) para realizar numerosas lectotipificaciones y a Prado et al. (2015) para las lectotipificaciones inferenciales o inadvertidas.

Los ejemplares citados como holotipos ("HT") para numerosos nombres en el tratamiento de Festuca publicado en "Catalogue of the New World Grasses" por Darbyshire et al. (2003), no son holotipos (cuando existen duplicados). Además, la indicación de "HT" no puede ser considerada como una lectotipificación efectiva ya que se publicaron después del 2001 sin incluir la frase "aquí designado" (Art. 7.10, McNeill et al. 2012). Muchos de estos nombres se lectotipifican aquí o se corrigen a lectotipo (Art. 9.9).

En cuanto a los nombres creados por R. A. Philippi, algunos especímenes originales fueron enviados de SGO a US en calidad de préstamo en los años 1903 o 1904, donde los fragmentos y las fotos de este material fueron montados como duplicados y un número de catálogo fue asignado a cada hoja. Este número de catálogo pudo haber sido asignado por Reiche en SGO o por Piper en US (R. Soreng, com. pers; G. Rojas, M. Muñoz, com. pers.). Estos ejemplares tipo volvieron a SGO, pero el número de catálogo que se observa en las hojas de US, en su mayoría no son visibles en las hojas originales de SGO. Luego, el herbario SGO envió algunos de estos ejemplares (tal vez los mismos ejemplares) a Edward Hackel en Viena (Austria), donde residen hoy en el herbario W. Por lo tanto, para las especies descritas por R. A. Philippi antes de 1903 y cuando los duplicados de diferentes herbarios llevan etiquetas manuscritas por Philippi, consideramos que se usó más de un ejemplar para la descripción original y los duplicados fueron posteriormente distribuidos a otros herbarios. En estos casos, es necesaria una lectotipificación siguiendo la recomendación 9A del Código, sin tener en cuenta los especímenes citados por Darbyshire et al. (2003) ni el número de catálogo (citado como por ejemplo: "SGO-PHIL-278").

Matthei (1982), en su revisión de Festuca de Chile, usó la palabra "Typus" para indicar el material original que estudió para cada especie; estos casos son aquí corregidos a lectotipo aplicando el Art. 9.9 del Código. Algunos otros casos, aparte de los de Matthei (1982) y 
anteriores a 2001 (a partir de este año las palabras "aquí designado" o un equivalente son necesarios para lectotipificaciones según el Art. 9.23), también están corregidos a lectotipos. Se indicó "lectotipo (o quizás holotipo)" cuando existen dudas en cuanto a si un ejemplar de un herbario en particular es o no es el holotipo, o cuando no tenemos pruebas de que el autor sólo vió un espécimen para describir una especie (McNeill 2014).

Se realizaron lectotipificaciones de segundo paso siguiendo el Art. 9.17 cuando existen dos o más ejemplares de la misma colección en el mismo herbario y cuando el autor de la primera lectotipificación no indicó exactamente un espécimen. Por último, se designaron lectotipos seleccionando el espécimen más completo y mejor conservado.

En CONC y SGO se estudiaron algunas fotos (fotos impresas) de especímenes tipo de otros herbarios. Esos casos se indican como "foto CONC!" o "foto SGO!". Las imágenes estudiadas de sitios web se indican como "imagen!".

Es importante resaltar que algunas de las novedades nomenclaturales resueltas durante este estudio, o nuevos sinónimos, que son parte del trabajo doctoral, ya fueron efectivamente publicadas en Ospina et al. (2013a; 2013b; 2015) y se señala esta bibliografía junto a la novedad. Otras novedades que se indican en este manuscrito serán efectivamente publicadas en trabajos futuros en elaboración.

\section{Concepto de especie}

En este capítulo se siguió el concepto morfológico de especie de Caín (1954): "Conjunto de individuos morfológicamente similares, generalmente asociados entre sí por una distribución geográfica definida y separados de otros conjuntos por discontinuidades morfológicas”.

\section{Descripciones morfológicas}

La descripción del género Festuca aquí presentada considera los caracteres morfológicos representados en las especies y en los sinónimos citados para el Cono Sur. Se presentan ilustraciones para cada especie mostrando los caracteres más importantes, para aquellas especies que no se pudieron ilustrar se muestra una imagen del material tipo o se señala iconografía. Se elaboró una clave con caracteres morfológicos para identificar las especies aquí reconocidas para el Cono Sur. 


\section{Distribución geográfica y regiones fitogeográficas}

Para cada especie se menciona la distribución geográfica en cada país del Cono Sur y el hábitat. Sólo se menciona en otros países cuando pudo corroborarse con bibliografía o materiales examinados fuera del Cono Sur. Para describir la distribución fitogeográfica de las especies de Festuca en el Cono Sur se sigue a Olson et al. (2001) y a Cabrera \& Willink (1973).

\section{RESULTADOS}

\section{$\underline{\text { Sistemática }}$}

Sobre la base de caracteres morfológicos vegetativos y reproductivos se reconocieron 41 especies y 2 variedades de Festuca que crecen en el Cono Sur. Se propone la variedad $F$. acanthophylla var. scabriuscula, basada en la especie Festuca scabriuscula.

Se excluyeron 5 especies de la flora del Cono Sur. Se ilustraron 14 especies para esta tesis. Muchas de las especies habían sido ilustradas previamente, pero las láminas aquí dibujadas son representativas del concepto de la especie en este tratamiento taxonómico. Festuca subantarctica se ilustra por primera vez.

\section{Nomenclatura}

Como resultado de la revisión nomenclatural se revisaron 177 nombres de taxones (aceptados y sinónimos), se establecieron 18 nuevos sinónimos, se designaron 23 lectotipos de primer paso y 16 de segundo paso, se corrigieron a lectotipo términos que denotan tipos para 36 lectotipificaciones inferenciales.

\section{Novedades corológicas para el Cono Sur}

Festuca werdermannii es una especie descripta por Saint-Yves (1927) para Chile. Luego de su descripción, sólo fue citada para la Flora de Chile (Alexeev 1984; Matthei 1982, Marticorena \& Quezada 1985). En el presente estudio se encontraron ejemplares recolectados en Argentina cuyas características se corresponden con las de $F$. werdermannii y ésta constituye la primera cita para el país. Los especímenes argentinos se hallaron erroneamente determinados bajo los 
nombres Festuca argentinensis, $F$. hypsophila, $F$. acanthophylla, $F$. villipalea ( $=F$. dissitiflora), $F$. weberbaueri y $F$. nardifolia. Sin embargo, estas especies pueden diferenciarse claramente de F. werdermannii por los caracteres de la Tabla I.

Tabla I. Atributos que permiten separar a Festuca werdermannii de otros taxones del Cono Sur.

\begin{tabular}{lcccc}
\hline \multicolumn{5}{c}{ CARACTERES MORFOLÓGICOS } \\
TAXONES & $\begin{array}{c}\text { Largo de la } \\
\text { lámina }(\mathrm{cm})\end{array}$ & $\begin{array}{c}\text { Largo de la } \\
\text { lígula }(\mathrm{mm})\end{array}$ & $\begin{array}{c}\text { Ápice del } \\
\text { ovario }\end{array}$ & $\begin{array}{c}\text { Quillas de la } \\
\text { pálea }\end{array}$ \\
\hline F. werdermannii & $6-10$ & $2-3,5$ & piloso & glabra \\
F. argentinensis & $4-8$ & $0,5-1$ & glabro & ciliada \\
F. hypsophila & $13-40$ & $0,3-0,5$ & glabro & ciliada \\
F. acanthophylla & $12-40$ & $0,6-1$ & piloso & ciliada \\
F. dissitiflora & $8-15(-23)$ & $1,5-2$ & glabro & ciliada \\
F. weberbaueri & $10-20$ & $0,3-0,7$ & glabro & ciliada \\
F. nardifolia & $1-4(-6)$ & $0,3-1,2$ & glabro & ciliada \\
\hline
\end{tabular}

La segunda novedad corresponde a $F$. rigescens, especie descripta para los Andes de Perú (Áncash, Puno; Tovar 1972) y citada para Bolivia (La Paz, Potosí; Renvoize 1998). En el catálogo de plantas vasculares del Cono Sur (Zuloaga et al. 2008) fue registrada para Argentina sobre la base del ejemplar Fabris 1838 (BAA), pero este ejemplar corresponde a $F$. dolichophylla. Esta especie no fue mencionada para la flora de Chile (Matthei 1982) y fue excluida para la flora Argentina (Catalán \& Müller 2012).

En el presente trabajo se encontraron ejemplares recolectados en Argentina y Chile cuyas características se corresponden con las de $F$. rigescens y, por lo tanto, se confirma y se amplía la distribución de la especie. Los ejemplares correspondientes a $F$. rigescens de Argentina y Chile se hallaron determinados principalmente como $F$. argentinensis y como $F$. hypsophila; también como F. nardifolia. Estos taxones pueden diferenciarse por los caracteres presentados en la Tabla II. 
Tabla II. Atributos que permiten separar a Festuca rigescens de otros taxones del Cono Sur.

\begin{tabular}{lccc}
\hline \multicolumn{1}{c}{ CARACTERES MORFOLÓGICOS } \\
\multicolumn{1}{c}{$\begin{array}{c}\text { Nro. de nudos / } \\
\text { ubicación en la caña }\end{array}$} & $\begin{array}{c}\text { Largo de la } \\
\text { lígula }(\mathrm{mm})\end{array}$ & $\begin{array}{c}\text { Forma de } \\
\text { la lema }\end{array}$ \\
\hline F. rigescens & $1 /$ distal & $0,5-1$ & falcada \\
F. argentinensis & $1 /$ basal & $0,5-1$ & no falcada \\
F. hypsophila & $1-2 /$ basal & $0,3-0,5$ & no falcada \\
F. nardifolia & sin nudos & $0,3-1,2$ & no falcada \\
\hline
\end{tabular}

La tercera novedad se trata de F. nardifolia, especie descripta originalmente para la Argentina sobre la base de ejemplares hasta de 5-7 cm de alto, de matas muy densas, subpulvinadas, de cañas e inflorescencias cortas, pauciespigadas, espiguillas 3-4 floras, lemas algo escabrosas hacia el ápice, con ápice agudo. Posteriormente se asignaron a esta especie ejemplares de Argentina y Chile de mayor altura, hasta de $15 \mathrm{~cm}$, con cañas e inflorescencias más largas, ampliando el concepto morfológico de la especie (Matthei 1982; Catalán \& Müller 2012). Sin embargo, estos ejemplares corresponden a individuos de F. rigescens de Argentina y Chile. Ambas especies son morfológicamente afines, sin embargo, pueden distinguirse por los caracteres de la siguiente clave:

1. Cañas floríferas de $12-18(-25) \mathrm{cm}$, con 1 nudo en la zona de entrenudos alargados; láminas de $(7-) 8-10(-12) \mathrm{cm}$, no rígidas, erectas a flexuosas o recurvas, ápice obtuso; gluma inferior menor a $1 / 2$ del largo de los antecios contiguos; lemas marcadamente falcadas Festuca rigescens

1. Cañas floríferas de (3-)5-6(-8) cm, sin nudos en la zona de entrenudos alargados; láminas de $1-4(-6) \mathrm{cm}$, rígidas, recurvadas a patentes, ápice acuminado; gluma inferior mayor a $1 / 2 \mathrm{del}$ largo de los antecios contiguos; lemas no falcadas Festuca nardifolia

En esta tesis se recircunscribe el concepto morfológico de $F$. nardifolia a lo descripto en el protólogo de la especie, se excluye de Chile y se restringe su distribución a la Argentina, constituyendo un endemismo para ese país. 
Tratamiento taxonómico

Festuca L., Sp. Pl. 1: 73.1753 (1 mayo 1753). ESPECIE TIPO: Festuca ovina L. Sp. Pl. 1: 7374. 1753 (1 mayo 1753) (lectotipo designado por Nash 1913: 269).

Plantas perennes, rizomatosas o cespitosas. Culmos floríferos desde $2 \mathrm{~cm}$ hasta de $1,10(-1,80)$ $\mathrm{m}$ de altura, sin nudos o con 1-8 nudos glabros en la zona de entrenudos alargados; innovaciones extravaginales o intravaginales. Vainas abiertas o parcialmente cerradas, vainas basales de algunas especies desintegradas en fibras, lisas o escabrosas, glabras o pilosas, lustrosas o no, en las especies rizomatosas formando escamas (catafilos). Pulvínulo de la vaina ausente o presente y piloso a glabro. Aurículas de las vainas presentes o ausentes. Lígulas de 0,3-3(3,5) mm de largo, truncadas, obtusas, emarginadas o bilobuladas, enteras, coriáceas a membranáceo-ciliadas. Láminas de 0,6-20(-25) $\mathrm{mm}$ de ancho, planas, expandidas a convolutas, o conduplicadas, escabrosas o lisas, pilosas o glabras, lustrosas o no, verdes, oliváceas en fresco y verde a pajizas en seco. Inflorescencias en panículas lineares o lanceoladas, contraídas o laxas, a veces reducidas a racimos por reducción de las ramas secundarias, ramas alternas en el raquis. Espiguillas lateralmente comprimidas, con (2-)4-8(12) antecios perfectos, con desarticulación de la raquilla arriba de las glumas y entre los antecios. Glumas 2, persistentes, lineares, lanceoladas a ovadas, no carinadas, subiguales o desiguales, en algunas pocas especies son iguales; la inferior 1-nervia (3-nervia solo en $F$. argentina); la superior 3-nervia (raramente 5-nervia en $F$. argentina). Lema del antecio basal coriácea o membranácea, el dorso redondeado (no carinado), escabrosas o lisas, pubescentes o glabras, lustrosas o no, con el ápice obtuso, agudo, acuminado, mucronado o aristado, 3(-5) nervia. Pálea de igual tamaño o más corta que la lema, membranácea, las quillas glabras, escabrosas, pilosas o ciliadas. Lodículas 2, bidentadas, hialinas. Anteras 3, de 0,3-5 mm de largo. Ápice del ovario glabro o piloso. Estilos terminales, estigmas 2, blancos. Fruto en cariopsis, con hilo linear. Plantas monoicas; casmógamas, algunas cleistógamas o prolíferas.

\section{$\underline{\text { Clave para diferenciar las especies de Festuca del Cono Sur }}$}

1. Plantas rizomatosas o estoloníferas, catafilos presentes, láminas a lo largo de la caña

$1^{\prime}$. Plantas cespitosas, catafilos ausentes, láminas principalmente basales 10

2(1). Aurículas mayores a $3 \mathrm{~mm}$ de largo, con dos lóbulos agudos y extendidos F. arundinacea 
$2^{\prime}$. Aurículas ausentes o menores a 0,5 mm de largo, sin lóbulos

3(2'). Lemas con aristas de 5-12 $\mathrm{mm}$ de largo F. ulochaeta

$3^{\prime}$. Lemas sin arista o aristadas, aristas hasta $1,7 \mathrm{~mm}$ de largo 4

4(3'). Gluma inferior mayor a $6 \mathrm{~mm}$ de largo 5

4'. Gluma inferior menor a 5,5 $\mathrm{mm}$ de largo 6

5(4). Lígulas de 3,5-5 mm de largo, espiguillas de 13-18 $\mathrm{mm}$ de largo, con 5-7 antecios F. superba

5'. Lígulas menores de $2 \mathrm{~mm}$ de largo, espiguillas de 18-25 mm de largo, con (8-)9-12 antecios. F. fimbriata

6(4'). Lemas sin aristas F. parodiana

6'. Lemas aristadas, aristas de $0,5-1,7 \mathrm{~mm}$ 7

$7\left(6^{\prime}\right)$. Ápice de la lígula truncado 8

$7^{\prime}$. Ápice de la lígula obtuso a redondeado 9

8(7). Plantas no estoloníferas, culmos floríferos con 1 nudo en la zona de entrenudos alargados, panículas rojizas F. rubra

8'. Plantas estoloníferas, culmos floríferos con (3-)4-5 nudos en la zona de entrenudos alargados, panículas pajizas F. yalaensis

9(7'). Culmos floríferos de 35-70 $\mathrm{cm}$ de alto, panículas de 9-17 cm de largo F. purpurascens

9'. Culmos floríferos de 100-150 cm de alto, panículas de $20-30 \mathrm{~cm}$ de largo F. nemoralis

$10\left(1^{\prime}\right)$. Superficie adaxial de la lámina glabra o con papilas 11

10'. Superficie adaxial de la lámina esparcida a densamente pilosa y sin papilas 15

11(10). Superficie adaxial de la lámina con papilas F. monticola 
$11^{\prime}$. Superficie adaxial de la lámina sin papilas

12(11'). Lema con ápice agudo y aristado

$12^{\prime}$. Lema con ápice agudo y sin arista

14

13(12). Arista de la lema de $0,5-1 \mathrm{~mm}$ de largo

F. subantarctica

$13^{\prime}$. Arista de la lema de $3-5 \mathrm{~mm}$ de largo F. cirrosa

14(12'). Culmos floríferos de 80-100 cm de alto, con 3-4 nudos en la zona de entrenudos alargados F. fiebrigii

14'. Culmos floríferos de 50-60 cm de alto, con 1-2 nudos en la zona de entrenudos alargados F. parodii

15(10'). Panículas usualmente reducidas a racimos (en $F$. gracillima y $F$. argentinensis las espiguillas rara vez están sobre ramas de segundo orden) 16

15'. Panículas con ramas de segundo o mayor orden 21

16(15). Láminas circinadas F. roigii

$16^{\prime}$. Láminas no circinadas

17(16'). Espiguillas de 12-20 $\mathrm{mm}$ de largo 18

$17^{\prime}$. Espiguillas de 4-10 $\mathrm{mm}$ de largo 19

18(17). Culmos floríferos mayores de $50 \mathrm{~cm}$ de alto, láminas de 1,5-2 $\mathrm{mm}$ de diámetro, rígidas y divergentes F. pallescens

18'. Culmos floríferos hasta de $45 \mathrm{~cm}$ de alto, láminas de 0,5-0,8 $\mathrm{mm}$ de diámetro, no rígidas y erectas F. gracillima

19(17'). Lema densamente escabrosa y pilosa F. pyrogea

$19^{\prime}$. Lema escasamente escabrosa hacia el ápice y glabra 20

$20\left(19^{\prime}\right)$. Lema con ápice agudo y arista de $1-2 \mathrm{~mm}$ de largo F. magellanica

$20^{\prime}$. Lema con ápice obtuso y sin arista F. ovina var. tenuifolia 
21(15'). Superficie adaxial de la lámina densamente pilosa, con largos pelos visibles entre los márgenes formando una línea blanca F. chrysophylla

21'. Superficie adaxial de la lámina pilosa, con pelos cortos no visibles entre los márgenes 22

22(21'). Gluma inferior 3-nervia, gluma superior (3-)5-nervia F. argentina

22'. Gluma inferior 1-nervia, gluma superior 3-nervia 23

23(22'). Panícula con ramas y raquis villoso-pubescentes F. lasiorrhachis

$23^{\prime}$. Panícula con ramas y raquis lisos o escabrosos 24

$24\left(23^{\prime}\right)$. Lema con arista de 1-10(-14) mm largo 25

$24^{\prime}$. Lema sin arista 38

25(24). Arista de la lema mayor de $5 \mathrm{~mm}$ de largo F. ventanicola

$25^{\prime}$. Arista de la lema menor de $4 \mathrm{~mm}$ de largo 26

$26\left(25^{\prime}\right)$. Aurículas de la vaina ausentes

$26^{\prime}$. Aurículas de la vaina presentes, a veces inconspicuas 28

27. Láminas menores a18 $\mathrm{cm}$ de largo

F. pallescens

$27^{\prime}$. Láminas mayores de $30 \mathrm{~cm}$ de largo F. distichovaginata

$28\left(26^{\prime}\right)$. Lígulas de $1,5-2,3 \mathrm{~mm}$ de largo 29

$28^{\prime}$. Lígulas de menos de $1,2 \mathrm{~mm}$ de largo 30

29(28). Culmos floríferos de 15-25 cm de alto, con 1 nudo en la zona de entrenudos alargados; aurículas de $1-1,7(-2) \mathrm{mm}$ de largo F. castilloniana

29'. Culmos floríferos de (20-)25-40 cm de alto, con 2 nudos en la zona de entrenudos alargados; aurículas de 0,5-1 mm de largo F. dissitiflora 30(28'). Culmos floríferos sin nudos en la zona de entrenudos alargados 31 $30^{\prime}$. Culmos floríferos con 1-4 nudos en la zona de entrenudos alargados 
31. Láminas de 1-4(-6) cm de largo, ápice del ovario glabro F. nardifolia

31'. Láminas de 8-18 cm de largo, ápice del ovario piloso F. contracta 32(30'). Lemas falcadas F. rigescens $32^{\prime}$. Lemas no falcadas 33 33(32'). Pulvínulo de la vaina ausente 34

$33^{\prime}$. Pulvínulo de la vaina presente 35

34(33). Plantas de 30-95 cm de alto, láminas de 12-40 cm de largo, inflorescencias de (6-)9-28 cm de largo, espiguillas con 5-8 antecios F. acanthophylla

34'. Plantas de $20-45 \mathrm{~cm}$ de alto, láminas de $10-25 \mathrm{~cm}$ de largo, inflorescencias de 8-10 $\mathrm{cm}$ de largo, espiguillas con 3-4 antecios F. uninodis

35(33'). Pulvínulo de la vaina glabro 36

$35^{\prime}$. Pulvínulo de la vaina piloso 37

36(35). Láminas divergentes a patentes, algunas veces recurvadas, de $8-16 \mathrm{~cm} \times 1-1,3 \mathrm{~mm}$ F. kurtziana

36'. Láminas erectas, de 4-8 $\mathrm{cm} \times 1,5-2,2 \mathrm{~mm}$ F. argentinensis 37(35'). Aurículas de la vaina inconspicuas F. hypsophila

$37^{\prime}$. Aurículas de la vaina de $1-1,3 \mathrm{~mm}$ de largo F. weberbauberi 38(24'). Panículas geniculadas a péndulas, de 3-4(-6) cm de largo F. panda $38^{\prime}$. Panículas erectas, mayores de $4 \mathrm{~cm}$ de largo 39 39(38'). Ápice del ovario glabro, láminas de 2,5-3,5 mm de ancho, panícula de 18-25(-30) cm de largo F. hieronymi

$39^{\prime}$. Ápice del ovario piloso, láminas de 0,9-3 mm de ancho, panícula de 4-16(-20) cm de largo 40 40(39’). Láminas hasta de $20 \mathrm{~cm}$ de largo F. pampeana $40^{\prime}$. Láminas hasta de $15 \mathrm{~cm}$ de largo 41 
41(40'). Culmos floríferos con 3 nudos en la zona de entrenudos alargados F. lilloi

$41^{\prime}$. Culmos floríferos sin nudos en la zona de entrenudos alargados F. wedermanii

\section{Descripción de las especies de Festuca para el Cono Sur}

1. Festuca acanthophylla É. Desv., Fl. Chil. 6 (Botanica): 434. 1854. TIPO: CHILE. VI Región: Provincia Colchagua, “Cordilleras altas de Cauquenes, Valle de los Cipreses”, 1831, C. Gay s.n. (holotipo P 00624400 imagen!, foto CONC!). Figura 1.

Clave para las variedades de Festuca acanthophylla

1. Superficie abaxial de láminas de hoja lisa, lustrosas var. acanthophylla

$1^{\prime}$. Superficie abaxial de lámina de la hoja escabrosa (con ganchos), no lustrosas

var. scabriuscula

a. var. acanthophylla

Festuca tunicata É. Desv., Fl. Chil. 6 (Botanica): 434. 1854. LECTOTIPO: CHILE. V Región: Provincia Quillota, “in pascuis et fruticetis asperis collium et montium Quillota”, octubre 1829, C. G. Bertero 995 (lectotipo (de primer paso) P designado por Matthei (1982: 51) corregido de "typus", lectotipo (de segundo paso) P 00625340 imagen! designado por Ospina et al. (2015: 8); isolectotipos BAA 1181!, BAA 1353!, BM 000884713 imagen!, G 00386425 imagen!, G 00386424 imagen!, P 00625341 imagen!, P 00625339 imagen!, LE TRIN 2848.02 imagen!, S S05 5080 imagen!, W 1889 0102854 imagen!, US 601353 imagen!, US 2547218 imagen!).

Festuca berteroniana Steud., Syn. Pl. Glumac. 1: 311. 1854. LECTOTIPO: CHILE. V Región: Provincia Quillota, "Quillota”, 1829, C. G. Bertero 999 (lectotipo (de primer paso) P designado por Matthei (1982: 51) corregido de "typus", lectotipo (de segundo paso) P 00625304 imagen! designado por Ospina et al. (2015: 8); isolectotipos P 00625305 imagen!, US 2875380 (frag. ex P) imagen!).

Festuca robusta Phil., Linnaea 29(1): 99. 1858. nom. illeg. hom., non F. robusta Mutel, Fl. Franc. 4: 118, t. 89, f. 623. 1837. LECTOTIPO: CHILE. Región Metropolitana: Provincia Santiago de Chile, "Cerro San Cristobal", diciembre 1855, F. Germain s.n. 
(lectotipo (de primer paso) SGO designado por Matthei (1982: 52) corregido de “typus", lectotipo (de segundo paso) SGO 063828! designado por Ospina et al. (2015: 8); isolectotipos SGO 063827!, SGO 062720!).

Festuca thermarum Phil., Anales Univ. Chile 21(4): 385. 1862. LECTOTIPO: CHILE. VIII Región: Provincia Ñuble, "en los manantiales de las Termas de Chillan", sin fecha, $F$. Philippi s.n. (lectotipo (de primer paso) SGO designado por Matthei (1982: 57) corregido de "typus", lectotipo (de segundo paso) SGO 06833! designado por Ospina et al. (2015: 8); isolectotipos SGO 037437!, US 556543 imagen!).

Festuca desvauxii Phil., Linnaea 33(3-4): 295. 1864. LECTOTIPO: CHILE. VI Región: Provincia Colchagua, "Ad radicem Andinum in prov. Colchagua in elevatione 2-3000 ped. s.m. cresit, umde attulit orn. Landbeck", noviembre 1860, L. Landbeck s.n. (lectotipo (de primer paso) SGO designado por Matthei (1982: 52) corregido de “typus", lectotipo (de segundo paso) SGO 063839! designado por Ospina et al. (2015: 8); isolectotipos SGO 037439!, SGO 071812! foto CONC!, US 1127133 (frag. ex W) imagen!, W 19160039741 imagen!).

Festuca acuta Phil., Anales Univ. Chile 94: 175. 1896. LECTOTIPO: CHILE. IV Región: Provincia Talca, "In andibus provincia Talca loco dicto Blanquillo invent", febrero 1888, F. Philippi s.n. (lectotipo SGO 037447! designado por Matthei (1982: 52), corregido de "typus"; isolectotipos CORD 00001637!, K 000433670 imagen!, US 556546 imagen!, US 556554 (frag. ex SGO) imagen!, W 19160004698 imagen!, W 19160039735 imagen!).

Festuca neuquenensis var. parodiana St.-Yves, Candollea 3: 298. 1927. LECTOTIPO: ARGENTINA. Neuquén: Departamento Picunches, "Pino Hachado", 1400 m s.m., 5 febrero 1920, L. R. Parodi 3195 (lectotipo BAA 1218!, designado por Matthei (1928: 57) corregido de "typus"; isolectotipo G 00386428 imagen!).

Festuca desvauxi var. ampla St.-Yves, Candollea 3: 298. 192. TIPO: CHILE. VII Región: Provincia Curicó, "Curico, Monte Grande", 1700 m, 12 diciembre 1924, E. Werdermann 520 (holotipo G (no encontrado); isotipos K 000433672 imagen!, SI 61799!, SI 61800!, BM 000622590 imagen!, E 00254712 imagen!).

Festuca barrazae Muñoz, Agric. Téchn. (Santiago) 8: 82. 1948. TIPO: CHILE. IV Región: Provincia Elqui, "Coquimbo, Bosque de Fray Jorge, aprox. 500 m.s.m., en una quebrada profunda de la ladera Poniente, más o menos abundante", 25-30 noviembre 1940, C. Muñoz \& A. Coronel 1393 (holotipo SGO 095396!). 
Plantas cespitosas, sin catafilos. Culmos floríferos 30-95 cm de alto, con 1-3(-4) nudos en la zona de entrenudos alargados, láminas principalmente basales. Vainas con la porción distal más ancha que la lámina, lisas, glabras o distalmente pilosas, pajizas o con tintes violáceos, lustrosas, cartáceas. Aurículas 0,5-0,8 mm, con lóbulos obtusos, lisas, glabras, margen membranáceo y cortamente ciliado. Pulvínulo de la vaina ausente. Lígulas 0,6-1 mm de largo, ápice truncado, margen membranáceo y cortamente piloso. Láminas $12-40 \mathrm{~cm} \times 0,6-1,3 \mathrm{~mm}$, conduplicadas, rígidas, erectas, ápice pungente; superficie abaxial glabra, lisa y brillante; superficie adaxial escabrosa, cortamente pilosa. Panículas (6-)9-28 cm de largo, lineares, laxas; ramas ascendentes, escabrosas y glabras. Espiguillas 9-15 $\mathrm{mm}$ de largo, con 5-8 antecios, pajizas o verdosas, algunas veces con tintes violáceos; raquilla escabrosa y glabra. Glumas subiguales, escabrosas hacia el ápice y dorso, con el nervio medio conspicuo; gluma inferior 3,5-6 mm de largo, igual o más larga que el 1/2 del antecio adyacente, ápice acuminado, 1-nervia; gluma superior 4,5-7 mm de largo, más corta que los $2 / 3$ del antecio adyacente, ápice agudo, glabra, 3-nervia. Lemas del antecio basal 5-7 mm de largo (sin arista), escabrosa en el dorso y en el ápice, algunas veces cortamente pilosa hacia el ápice, ápice acuminado o algunas veces aristado, arista de 0,8-1,5 mm de largo. Páleas con quillas ciliadas. Lodículas 1-1,2 mm de largo, lobadas, margen eroso, glabras. Anteras 2-4,5 mm de largo. Ápice del ovario piloso.

Distribución y hábitat. Este taxón se distribuye desde $32^{\circ}$ hasta $37^{\circ} \mathrm{S}$, entre $1000-3000 \mathrm{~m}$ de altitud. Crece en suelos pedregosos sobre las laderas de las altas montañas en la cordillera de los Andes y en campos con presencia de nieve temporal en Chile (desde la IV a la IX Región) y en Argentina (Mendoza y Neuquén). Es un componente importante de los pastizales en de las provincias biogeográficas Altoandina, del Desierto y Puneña.

Observaciones. Esta especie se distingue fácilmente entre las demás de hoja fina de Festuca del Cono Sur, por el porte de la planta (30-95 cm de alto), las vainas cartáceas, por sus láminas conduplicadas, erectas, rígidas, lisas y lustrosas. Número cromosómico $2 n=42$ (Dubcovsky \& Martínez 1991).

Notas nomenclaturales. Steudel (1854) citó en el protólogo de Festuca coiron dos sintipos: "Festuca nr. 269 et 995. Bert. Hrbr. Chili". No se halló ningún ejemplar "Bertero 269", sin embargo, el ejemplar P 625339 tiene una etiqueta manuscrita por el autor donde se especifica "995 = 269". Por lo tanto, se consideró que "Bertero 995" y "Bertero $995=269$ " pertenecen a la misma colección: Quillota, octubre 1829; así, Festuca coiron es un nombre superfluo de $F$. tunicata. 
Matthei (1982) diferenció a Festuca tunicata de F. acanthophylla por el contorno de la lámina (circular vs. elíptica, respectivamente) y por la superficie abaxial de la lámina (generalmente escabrosa vs. glabra, respectivamente). Los isolectotipos de $F$. tunicata (P 00386424 y G 00625341) llevan dibujos de la sección transversal de la hoja donde se observa el contorno en forma de U y la superficie abaxial glabra. Por lo tanto, se propone a F. tunicata como nuevo sinónimo de $F$. acanthophylla var. acanthophylla.

Por otra parte, Festuca berteroniana, F. robusta y F. barrazae fueron citados como sinónimos de F. tunicata por Matthei (1982: 51), Marticorena \& Quezada (1985) y Darbyshire et al. (2003), pero los caracteres morfológicos de los ejemplares tipo y las descripciones de los protólogos de estos nombres se corresponden con los descriptos para $F$. acanthophylla var. acanthophylla. Por ende, se proponen dichos taxones como nuevos sinónimos de este último nombre.

Festuca thermarum fue tratado por Matthei (1982) como una especie de amplia distribución en Chile. Se examinaron numerosos especímenes de Chile asignados ya sea a $F$. acanthophylla o a $F$. thermarum y no se observaron diferencias en cuanto a la pilosidad de la hoja y de la vaina (caracteres utilizados por Matthei). Se observó que los especímenes asignados a $F$. thermarum son plantas pequeñas de $F$. acanthophylla y por ende, se propone el nuevo sinónimo.

Festuca neuquenensis var. parodiana St.-Yves fue citada como sinónimo de F. thermarum por Matthei (1982: 51), Marticorena \& Quezada (1985), Darbyshire et al. (2003) y Catalán \& Müller (2012). Sin embargo, los caracteres morfológicos de este taxón y la descripción en el protólogo se corresponden con los descriptos para F. acanthophylla var. acanthophylla. Por lo tanto, se propone a $F$. neuquenensis var. parodiana como nuevo sinónimo de $F$. acanthophylla var. acanthophylla.

b. var. scabriuscula (Phil.) J. C. Ospina, Aliscioni \& S. Denham, comb. nov. (Ospina et al. 2015: 11). Festuca scabriuscula Phil. Linnaea 29(1): 98. 1858. Festuca robusta var. scabriuscula (Phil.) St.-Yves Candollea 3: 187. 1927. TIPO: CHILE. VIII Región: Provincia Ñuble, "Región alpina de Chillán", sin fecha, R. A. Philippi s.n. (holotipo SGO 071991!). Figura 2.

Festuca asperata Phil., Linnaea 33(3-4): 296. 1864. LECTOTIPO: CHILE. IV Región: Provincia Choapa, "Prope Illapel", sin fecha, L. Landbeck s.n. (lectotipo B 100002554 imagen! designado por Matthei (1982: 51) corregido de "typus"; isolectotipos SGO 063846!, US 556555 (fragmento) imagen!, W 19160039732 imagen!). 
Festuca pascua Phil., Anales Univ. Chile 94: 176. 1896. LECTOTIPO: CHILE. XIV Región: Provincia Valdivia, "Valdivia, pantanos", sin fecha, R. A. Philippi s.n. (lectotipo (de primer paso) SGO, designado por Matthei (1982: 56) corregido de "typus", lectotipo (de segundo paso) SGO 063842! designado por Ospina (2015: 11); isolectotipo SGO $37444 !)$.

Festuca steudelii Phil., Anales Univ. Chile 94: 177. 1896. LECTOTIPO: CHILE. XIV Región: Provincia Valdivia, "in andibus loco dicto Queni”, enero 1887, O. Philippi s.n. (lectotipo SGO 063817! designado por Matthei (1982: 56) corregido de "typus"; isolectotipos US 556541 imagen!, W 19160039752 imagen!).

Festuca neuquenensis var. aspera St.-Yves, Candollea 3: 300. 1927. LECTOTIPO: ARGENTINA. Neuquén: Departamento Picunches, "Pino Hachado", sin fecha, L. R. Parodi 3175 (lectotipo BAA 1275! designado por Matthei (1982: 56) corregido de "typus"; isolectotipo G 00386426 imagen!).

Festuca cabrerae Parodi, Revista Argent. Agron.20: 200. 1953. TIPO: ARGENTINA. Neuquén: Departamento Huiliches, "Lago Huechulafquen", 17 diciembre 1952, A. L. Cabrera 11284 (holotipo BAA 1165 (no encontrado); isotipos US 2154170 imagen!, LP 001471 ).

Festuca morenensis Matthei, Gayana, Bot. 37: 54, f. 6A, 24A. 1982. TIPO: CHILE. II Región: Provincia Antofagasta, "Antofagasta, cumbres al lado sur del morro Moreno", 2329'S $70^{\circ} 34^{\prime} \mathrm{W}, 1000 \mathrm{~m}$, M. Ricardi, C. Marticorena \& O. Matthei 1407 (holotipo CONC $50000 !)$.

Distribución y hábitat. Esta variedad se distribuye desde $20^{\circ}$ hasta $41^{\circ} \mathrm{S}$, entre $700-2200 \mathrm{~m}$ de altitud. Crece en suelos pedregosos, sobre laderas de las altas montañas en la cordillera de los Andes y en campos con presencia de nieve temporal en Chile (desde la II hasta la XIV Región) y Argentina (Neuquén hasta Río Negro). Se encuentra en las mismas provincias biogeográficas que la variedad tipo, además de la provincia Chilena.

Observaciones. Número cromosómico 2n $=42$ (Dubcovsky \& Martínez 1991).

Notas nomenclaturales. Se propone a $F$. scabriuscula como una variedad de $F$. acanthophylla debido la presencia de especímenes con la superficie abaxial de la hoja escasamente escabrosa, que podrían ser asignados a cualquiera de las dos especies. 
El espécimen SGO 63842 de Valdivia (lectotipo de F. pascua), fue erróneamente citado como isotipo de F. scabriuscula y también de F. pascua por Muñoz (1960), Catalán \& Müller (2012); estos autores no consideraron que la localidad de ese ejempalr fue corregida por Philippi (1896: 177): "Por un error he atribuido a la F. scabriuscula [Linnea 29(1): 98, 1858] una patria falsa; no es de las pampas de Valdivia sino de la región alpina de Chillan".

De acuerdo con el carácter de las hojas abaxialmente escabrosas, los siguientes nombres: Festuca asperata (considerado como sinónimo de F. tunicata, por Matthei 1982), F. steudelii (considerado como sinónimo de F. scabriuscula, por Matthei 1982) se proponen como sinónimos nuevos de F. acanthophylla var. scabriuscula.

A diferencia de Matthei (1982: 51), quien citó a F. cabrerae como sinónimo de F. kurtziana y de Catalán \& Müller (2012) que la reconocen como un taxón distinto, los caracteres morfológicos de los espécimen tipo (y los que figuran en el protólogo) permiten proponer a $F$. cabrerae como sinónimo nuevo de $F$. acanthophylla var. scabriuscula.

Festuca morenensis, que sólo se conoce a partir del holotipo, fue separado de F. scabrisucula por Matthei (1982) por la longitud de la lema, el diámetro de la hoja y las características de las células de la epidermis abaxial. Las características estudiadas del holotipo permiten considerarlo dentro de la variabilidad morfológica de F. acanthophylla var. scabriuscula.

2. Festuca argentina (Speg.) Parodi, Physis (Buenos Aires) 11: 498. 1935. Poa argentina Speg., Revista Fac. Agron. Vet. La Plata 3(30-31): 584-585. 1897. LECTOTIPO: ARGENTINA. Santa Cruz: Departamento Lago Argentino, "Hab. ad margim orientalem Lago Argentino", 1884, Tonini del Furia s.n. [Herb. Spegazzini 59], (lectotipo LP 001626! designado por Parodi (1935: 498-499) corregido de "typus"; isolectotipos BAA 2455!, US 81670 imagen!). Figura 3.

Festuca cavillieri St.-Yves, Candollea 3: 192, f. 27. 1927. LECTOTIPO: CHILE. XI Región. Provincia Pehuenche: "Chili: territoire de Pehuenche, Lechl. pl. Chil. edit. Hohenacker", diciembre 1856, W. Lechler 3085 (lectotipo G 00099499 imagen! designado por Matthei (1982: 49) corregido de "typus"; isolectotipos P 00625302 imagen!, P 00625303 imagen!, S SR 2250 imagen!).

Plantas cespitosas, sin catafilos. Culmos floríferos 60-90(-100) $\mathrm{cm}$ de alto, con 1(-2) nudos en la zona de entrenudos alargados, láminas mayormente basales. Vainas con la porción distal más ancha que la lámina, escasamente pilosas en la zona distal, pajizas a purpuras, no lustrosas, 
membranáceas. Aurículas ausentes. Pulvínulo de la vaina presente, piloso. Lígulas $0,8-1 \mathrm{~mm}$ de largo, ápice truncado, membranáceo-ciliado. Láminas $18-30(-35) \mathrm{cm} \times 1-2 \mathrm{~mm}$, conduplicadas, rígidas, erectas, ápice agudo a obtuso; superficie abaxial glabra; superficie adaxial cortamente pilosa. Panículas $8-15 \mathrm{~cm}$ de largo, lineares, contraídas; ramas adpresas al raquis, lisas, esparcidamente pilosas. Espiguillas $10-14 \mathrm{~mm}$ de largo, con $4-8$ antecios, verdosas a pajizas; raquilla esparcidamente pilosa. Glumas subiguales, esparcidamente pilosas hacia el ápice, con el nervio medio conspicuo; gluma inferior 5,6-7 mm de largo, más larga que el $1 / 2$ del antecio adyacente, ápice agudo a raramente obtuso, 3-nervia; gluma superior 6-8 $\mathrm{mm}$ de largo, más corta que los $2 / 3$ del antecio adyacente, ápice obtuso, (3-)5-nervia. Lemas del antecio basal 8-9,5 $\mathrm{mm}$ de largo, ápice agudo a obtuso, escabrosa esparcidamente pilosas hacia el ápice. Páleas con quillas ciliadas. Lodículas 1-1,5 mm de largo, lobadas, margen entero, pilosas. Anteras 3-4 mm de largo. Ápice del ovario piloso.

Distribución y hábitat. Esta especie se distribuye desde $33^{\circ}$ hasta $50^{\circ} \mathrm{S}$, entre $50-1500 \mathrm{~m}$ de altitud. Crece en las estepas graminosas sobre suelos arenosos, en los bordes de los cuerpos de agua o se puede encontrar formando matas aisladas en suelos fríos en Argentina (desde Mendoza hasta Santa Cruz) y en Chile (se conocen solamente dos colecciones de la XI Región). Es un componente característico de la formación “coironal” (Cabrera \& Willink 1973) y de la estepa patagónica de las provincias biogeográficas: Chilena central, Patagónica y Subantártica.

Observaciones. Esta especie se diferencia fácilmente por sus espiguillas amplias, gluma inferior 3-nervada, gluma superior (3-)5-nervada y lodículas pilosas. Comúnmente se conoce como "coirón negro", "coirón grande", "duro coirón", "huecú" y es tóxica para el ganado según Parodi (1950). Número cromosómico 2n = 28 (Dubcovsky \& Martínez 1992).

3. Festuca argentinensis (St.-Yves) Türpe, Darwiniana 15: 254. 1969. Festuca scirpifolia var. argentinensis St.-Yves, Candollea 5: 138. 1932. LECTOTIPO: ARGENTINA. Catamarca: Departamento Tinogasta: "Reales Blancos", 4000 m, 2 febrero 1930, $R$. Schreiter 6119 (lectotipo (de primer paso) designado por Türpe (1969: 254), corregido de "tipo", lectotipo (de segundo paso) LIL 44139! aquí designado; isolectotipos BAB, MVFA 0000358 (ex LIL 441392, 2 cartulinas). Figura 4.

Plantas densamente cespitosas, sin catafilos. Culmos floríferos $8-15(-20) \mathrm{cm}$ de alto, con 1 nudo en la base de la zona de entrenudos alargados, láminas mayormente basales. Vainas con la porción distal más ancha que la lámina, glabras, pajizas blanquecinas, lustrosas, membranáceas. 
Aurículas $0,5-1 \mathrm{~mm}$ de largo, con lóbulos truncados, esparcidamente escabrosas, margen membranáceo-eroso y ciliado. Pulvínulo de la vaina presente, glabro. Lígulas $0,5-1 \mathrm{~mm}$ de largo, ápice truncado, margen membranáceo-eroso y ciliado. Láminas $4-8 \mathrm{~cm} \times 1,5-2,2 \mathrm{~mm}$, plegadas, conduplicadas, rígidas, erectas, ápice atenuado y rostrado, pungente; superficie abaxial glabra; superficie adaxial pilosa. Panículas 4-8 cm de largo, lineares, contraídas; ramas adpresas al raquis, escabrosas. Espiguillas (8-)9-11 mm de largo, con 4-6 antecios, verdosas a pajizas; raquilla esparcidamente escabrosa. Glumas subiguales, distalmente escabrosas, con el nervio medio conspicuo; gluma inferior $2-2,5(-2,8) \mathrm{mm}$ de largo, más corta que el $1 / 2 \mathrm{del}$ antecio adyacente, ápice agudo, 1-nevia; gluma superior (3,2-)3,5-4 mm de largo, más corta los $2 / 3$ del antecio adyacente, ápice obtuso, 3-nevia. Lemas del antecio basal $(4,8-) 5-5,5 \mathrm{~mm}$ de largo (sin arista), oblonga, esparcidamente escabrosa, ápice atenuado a cortamente aristado, arista $0,5-1 \mathrm{~mm}$ de largo. Páleas con quillas ciliadas. Lodículas $0,6-1 \mathrm{~mm}$ de largo, lobadas, glabras. Anteras 3-3,5 mm de largo. Ápice del ovario glabro.

Distribución y hábitat. Esta especie se distribuye desde $18^{\circ}$ hasta $29^{\circ} \mathrm{S}$, entre $3200-4600 \mathrm{~m}$ de altitud. Crece en suelos rocosos sobre las laderas de las montañas andinas y forma matas aisladas cuando crece cerca a los cuerpos de agua en Argentina (desde Salta hasta San Juan). Además, se distribuye en Bolivia según Renvoize (1998). Es característica de las estepas de la provincia biogeográficas Altoandina.

Observaciones. Es similar a $F$. rigescens, pero esta última se distingue por presentar los culmos floríferos con un solo nudo en el área distal de la zona de entrenudos largos, sus aurículas con lóbulos obtusos y con el margen entero, sus láminas no rígidas y flexuosas, con el ápice obtuso, no pungente, así como por sus lemas falcadas. Número cromosómico $2 n=42$ (Dubcovsky \& Martínez 1991).

Notas nomenclaturales. Saint Yves (1932) designa varios sintipos para Festuca scirpifolia var. argentinensis: Schreiter 6119, Parodi 9602, 9612, 9657, 9656 y 9648. Türpe (1969) selecciona el ejemplar Schreiter 6119 como "tipo de la especie", pero existen duplicados de este ejemplar en LIL, BAB y MVFA; se selecciona aquí el ejemplar de LIL como lectotipo.

4. Festuca arundinacea Schreb., Spic. Fl. Lips. 57. 1771 (julio-octubre 1771), nom. cons. Festuca elatior L., Sp. Pl. 1: 75.1753 (1 mayo 1753), nom. rej. Festuca elatior var. arundinacea (Schreb.) Roth, Tent. Fl. Germ. 2: 141. 1789. Bromus arundinaceus (Schreb.) Roth, Tent. Fl. Germ. 2: 141. 1789. Schedonorus arundinaceus (Schreb.) 
Dumort., Observ. Gramin. Belg. 106. 1824. Festuca elatior subsp. arundinacea (Schreb.) Čelak., Prodr. Fl. Bohmen, 1: 51. 1867. Lolium arundinaceum (Schreb.) Darbysh., Novon 3(3): 241. 1993. LECTOTIPO: Scheuchzer, Agrostographia t. 5, f. 18. 1719 (lectotipo designado por Reveal et al. 1991: 136). EPITIPO: ÁFRICA. South Morocco, Greater Atlas, Amsmiz, 3-6000', mayo 1871, Dr. Hooker s.n. (K000345320 imagen!, designado por Sutrishna et al. 2015: 93).

Plantas rizomatosas, con catafilos. Culmos floríferos 40-60(-70) cm de alto, con 1-2 nudos en la zona de entrenudos, láminas a lo largo de los culmos. Vainas con la porción distal no más ancha que la lámina, escabrosas y esparcidamente pilosas en la zona distal, verdosas a pajizas, cartáceas. Aurículas 3-4 mm de largo, con lóbulos agudos y extendidos, conspicuas, margen membranáceo-ciliado. Pulvínulo de la vaina ausente. Lígulas 1-2 $\mathrm{mm}$ de largo, ápice truncado, margen membranáceo-ciliado. Láminas $10-30(-40) \mathrm{cm} \times 5-7 \mathrm{~mm}$, planas, expandidas, a convolutas, no rígidas, erectas, ápice agudo; superficie abaxial glabra; superficie adaxial esparcidamente escabrosa. Panículas 15-30 cm de largo, lanceoladas, laxas; ramas ascendentes a patentes, esparcidamente escabrosas. Espiguillas $9-15 \mathrm{~mm}$ de largo, con 5-7 antecios, verdosas y con tintes violáceos; raquilla escabrosa. Glumas subiguales, distalmente escabrosas, con el nervio medio conspicuo; gluma inferior 4-5 mm de largo, más largas que el $1 / 2$ del antecio adyacente, ápice agudo, 1-nevia; gluma superior 5-8 mm de largo, más corta que los $2 / 3$ del antecio adyacente, ápice agudo, 3-nevias. Lemas del antecio basal 6-8 mm de largo ( in arista), distalmente escabrosas, esparcidamente pilosas en el margen, ápice aristado, arista 0,5-2 mm de largo. Páleas con quillas escabrosas. Lodículas $0,5-1,5 \mathrm{~mm}$ de largo, lobadas, margen entero, glabras. Anteras 3-4,5 mm de largo. Ápice del ovario glabro.

Iconografía. Nicora (1978: 98. Fig. 55).

Distribución y hábitat. Especie introducida, ampliamente cultivada como forrajera en Argentina, Chile, Paraguay y Uruguay (observaciones personales y Matthei 1982, Darbyshire et al. 2003, Rúgolo et al. 2008, Catalán \& Müller 2012). Se estudiaron muestras de herbario desde $23^{\circ}$ hasta $35^{\circ} \mathrm{S}$, entre $300-2370 \mathrm{~m}$. Se distribuye en áreas húmedas de Eurasia y el norte de África y se ha introducido en América del Sur, América del Norte y Australia (Lazaridez 2002). De acuerdo con Matthei (1982), la introducción de este taxón en Chile fue en 1904, de una variante llamada K31 que se originó en Kentucky (USA).

Observaciones. Festuca arundinacea se distingue por desarrollar rizomas, y por las aurículas conspicuas y de margen ciliado. Esta especie es tratada de diversas maneras; en el género Festuca (Catalán \& Müller 2012, Matthei 1982), en Schedonorus (Darbyshire 2007) o como 
especie de Lolium (Darbyshire 1993). Si bien hay numerosos taxones subespecíficos descriptos para este taxón, ninguno ha sido descripto para el Cono Sur. Número cromosómico $2 n=42$ (Jauhar 1975; Ghorai y Sharma 1981; Kirschner et al 1982; Fuchs et al. 1995).

5. Festuca castilloniana Türpe, Lilloa 33(13): 285. 1973. TIPO: ARGENTINA. Tucumán: Departamento Tafí del Valle, "Cumbres Calchaquíes, Portezuelo", 3600 m s.m., marzo 1913, L. Castillón 2884 (holotipo LIL 44250!; isotipo BAA 00002021!).

Plantas cespitosas, sin catafilos. Culmos floríferos $15-25 \mathrm{~cm}$ de alto, con 1 nudo en la zona de entrenudos alargados, láminas mayormente basales. Vainas con la porción distal más ancha que las láminas, escabrosas, pajizas, no lustrosas, cartáceas. Aurículas 1-1,7(-2) mm de largo, lobuladas y escariosas, conspicuas, esparcidamente escabrosas, glabras, el margen ciliolado. Pulvínulo de la vaina usualmente presente, piloso. Lígulas 2-2,3 mm de largo, ápice truncado, margen membranáceo-ciliado. Láminas $3-7 \mathrm{~cm} \times 1-1,3 \mathrm{~mm}$, conduplicadas, ligeramente rígidas, erectas a curvadas, ápice agudo a obtuso; superficie abaxial esparcidamente escabrosa y pilosa en la base; superficie adaxial escabrosa y esparcidamente pilosa. Panículas 6-10 $\mathrm{cm}$ de largo, lineares, contraídas; ramas adpresas al raquis, escabrosas. Espiguillas 6-8 mm de largo, con 4-5 antecios, verdosas a grisáceas con tintes violáceos; raquilla escabrosa. Glumas subiguales, escabrosas hacia el ápice, con el nervio medio conspicuo; gluma inferior 4-4,5 mm de largo, $1 / 2$ o más larga que el 1/2 del antecio adyacente, ápice agudo, 1-nervia; gluma superior 5-5,5 mm de largo, más corta que los $2 / 3$ del antecio adyacente, ápice agudo a obtuso, 3-nervia. Lemas del antecio basal 4-5 mm de largo (sin arista), ápice aristado, escabrosa hacia el ápice, arista $0,8-1 \mathrm{~mm}$ de largo. Páleas con quillas ciliadas. Lodículas 1-1,5 mm de largo, lobadas, margen entero, glabras. Anteras 1,8-2,3 mm de largo. Ápice del ovario glabro.

Iconografía. Ilustración del ejemplar tipo que acompaña al protólogo en Lilloa 33(13): 285. 1973.

Distribución y hábitat. Esta especie se conoce solamente de la colección tipo, en las estepas de la provincia biogeográfica Altoandina en Tucumán.

Observaciones. Esta especie se caracteriza por sus cañas floríferas uninodes, por su lígula membranácea de 2-2,3 $\mathrm{mm}$ de largo, por sus láminas foliares de 1-1,3 $\mathrm{mm}$ de diámetro y sus espiguillas escabrosas. Se pudo estudiar el holotipo señalado en el protólogo por la autora 
depositado en LIL y además se halló un duplicado en BAA. Es considerada una buena especie, aunque no se registraron más ejemplares en el área de estudio.

6. Festuca chrysophylla Phil., Verz. Antofagasta Pfl. 88. 1891. Festuca deserticola var. chrysophylla (Phil.) St.-Yves, Candollea 3: 212. 1927. LECTOTIPO: CHILE. IV Región: Provincia Huasco, "Incahuasi”, 22 febrero 1885, F. Philippi s.n. (lectotipo SGO 68814! designado por Ospina et al. (2013a: 5); isolectotipos LP 290542!, SGO 62721!, SGO 37422!, SGO 71823!, US 556557 imagen!, W 19160039766 imagen!). Figura 5.

Festuca orthophylla Pilg., Bot. Jahrb. Syst. 25(5): 717. 1898 (23 diciembre 1898). TIPO: PERU. Arequipa: Provincia Arequipa, "Peruvia: Vincocaya, in vicinitae oppidi Arequipa (coll. Peruv. No 87)", 1 febrero 1877, A. Stübel 87 (holotipo B 4726b imagen!; isotipo US 81579 imagen!).

Festuca eriostoma Hack., Oesterr. Bot. Z. 53: 32. 1903. Festuca orthophylla var. eriostoma (Hack.) St.-Yves, Candollea 3: 195. 1927. LECTOTIPO: ARGENTINA. La Rioja: Departamento Famatina, "Sierra de Famatina, entre la Mina Yareta y la altura de Espíritu Santo", 26 enero 1879, G. H. E. Hieronymus \& G. Niederlein 781 (lectotipo W 19160004728 imagen! designado por Alexeev (1984: 348); isolectotipos B 4704 imagen!, JE 00004960 imagen!, K, S SR 2262 imagen!, CORD 00001639!, CORD 00001640 !, US 2875407 imagen!).

Festuca orthophylla var. glabrescens Pilg., Bot. Jahrb. Syst. 37: 507. 1906. Festuca orthophylla subvar. glabrescens (Pilg.) St.-Yves, Candollea 3: 197. 1927. LECTOTIPO: PERÚ. Puno: "Ad vicum Pucara in via Ferrea inter Oppida Puno et Cuzco, in pratis apertis frequentissima", $3700 \mathrm{~m}$, febrero 1902, A. Weberbauer 408 (lectotipo B 100250137 imagen! designado por Alexeev (1984: 348); isolectotipo S SR 2290 imagen!).

Festuca orthophylla var. boliviana Pilg., Bot. Jahrb. Syst. 37: 508. 1906. Festuca orthophylla subvar. boliviana (Pilg.) St.-Yves, Candollea 3: 196. 1927. LECTOTIPO: BOLIVIA. "Bolivia australis: in Puna Patanca, magnas altiplanitiei partes occupans", $3700 \mathrm{~m}$, marzo 1904, K. Fiebrig 3192 (lectotipo B 100250138 imagen! designado por Ospina et al. (2015: 18); isolectotipos COL 308762!, , K 000433593 imagen!, K 000433594 imagen!, S S054913 imagen!, S S054914 imagen!, S SR 2289 imagen!, US 81578 imagen!). 
Festuca orthophylla var. meyenii St.-Yves, Candollea 3: 198. 1927. Festuca meyenii (St.-Yves) E. B. Alexeev, Bot. Žhurn. (Moscow \& Leningrad) 69: 348. 1984. LECTOTIPO: PERÚ. Arequipa: Provincia desconocida: "Perou: ad pedem M. ignivomi Arequipa", abril 1831, F. Meyen s.n. (lectotipo (de primer paso) B designado por Alexeev (1984: 348), corregido de "typus", lectotipo (de segundo paso) B 100002597 imagen! designado por Ospina et al. (2015: 18); isolectotipos B 100002598 imagen!, B 10 0002599 imagen!).

Festuca deserticola var. juncea St.-Yves, Candollea 3: 209. 1927. Festuca juncea Phil., Verz. Antofagasta Pfl. 88, 89. 1891, nom. illeg. hom., non Festuca juncea (L.) Moench, 1794.). LECTOTIPO: CHILE. III Región: Provincia Tarapacá, “Aguas calientes et Socaire", 3200 m, F. Philippi s.n. (lectotipo SGO 63822! designado por Ospina et al. (2013a: 7); isolectotipos SGO 37433!, SGO 62724!, W 1916 0039745, foto!, US 556551, foto! (fragm. ex SGO)).

Plantas densamente cespitosas, sin catafilos (raramente con rizomas cortos). Culmos floríferos 18-70 cm de alto, con 1-2 nudos en la zona de entrenudos alargados, láminas mayormente basales. Vainas con la porción distal no más ancha que la lámina, distalmente pilosas, pajizas, lustrosas, membranáceas a cartáceas. Aurículas ausentes. Pulvínulo de la vaina presente, piloso. Lígulas 0,3-1 mm de largo, ápice truncado, margen membranáceo-entero. Láminas 8$20 \mathrm{~cm} \times 1-1,8 \mathrm{~mm}$, conduplicadas, rígidas, erectas a divergentes, ápice pungente; superficie abaxial glabra; superficie adaxial escabrosa y densamente pilosa, con largos pelos visibles entre los márgenes formando una línea blanca. Panículas (6-)10-20 cm de largo, lineares, contraídas; ramas adpresas al raquis, pobremente escabrosas y esparcidamente pilosas. Espiguillas 8-10 mm de largo, con 4-6 antecios, pajizas a verdosas; raquilla escabrosa y glabra. Glumas subiguales, escabrosas y distalmente pilosas, con el nervio medio conspicuo; gluma inferior 4,4-5,2 mm de largo, más larga que el 1/2 del antecio adyacente, ápice agudo, 1-nevia; gluma superior 6-7 mm de largo, $2 / 3$ o más corta que los $2 / 3$ del antecio adyacente, ápice obtuso, 3nevias. Lemas del antecio basal 5-6,8 $\mathrm{mm}$ de largo, escabrosas distalmente y densamente pilosas en el margen, ápice acuminado. Páleas con quillas ciliadas. Lodículas $0,8-1 \mathrm{~mm}$ de largo, lobadas, margen entero. Anteras 3-5,5 mm de largo. Ápice del ovario glabro.

Distribución y hábitat. Esta especie se distribuye desde $17^{\circ}$ hasta $28^{\circ} \mathrm{S}$, entre $3200-4900 \mathrm{~m}$ de altitud. Crece en suelos arenosos o rocosos, laderas de altas montañas, cerca de los cuerpos de agua y en campos con presencia de nieve temporal en Chile (desde la II a la XV Región) y en Argentina (desde Salta hasta La Rioja). Además, se distribuye en Bolivia (La Paz, Oruro, Potosí 
y Tarija) y Perú (Arequipa, Cerro de Pasco, Junín y Tacna) según Türpe (1969), Tovar (1972), Renvoize (1998) y Catalán \& Müller (2012). Es un componente florístico característico y con abundancia significativa en las estepas graminosas de las provincias biogeográficas Altoandina, Puna y del Desierto.

Observaciones. Esta especie es fácil de reconocer entre las especies del género Festuca ya que sus láminas presentan la superficie adaxial densamente pilosa, estos pelos sobresalen entre los márgenes y forman una línea blanca desde la base hasta la parte media de la lámina, así como por el margen densamente piloso de las lemas. Es similar a $F$. hypsophila (difiere por presentar laminas con superficie adaxial cortamente pilosas y lemas glabras). Comúnmente se conoce como: "Iru", "Iro", "Ichu", o "Paja de puna". Número cromosómico 2n $=42$ (Dubcovsky \& Martínez 1991).

Notas nomenclaturales. En el protologo de F. chrysophylla, R. A. Philippi menciona un ejemplar de Incahuasi de la colección de F. Philippi. Aquí designamos el ejemplar F. Philippi s.n. (SGO-68814) como lectotipo de F. chrysophylla, ya que el mismo corresponde a esa localidad y fue coleccionado por Federico Philippi. El ejemplar erróneamente publicado como holotipo en Tropicos (www.mobot.org) y Catalán \& Müller (2012), R.A. Philippi s.n. (SGOPhil-297), es de la localidad de Tarapacá y no se ha localizado en SGO.

Pilger (1906) cita un espécimen en el protologo de F. orthophylla var. boliviana pero no menciona el herbario; se encontraron varios duplicados de esta colección en B, COL, K, S y US; se selecciona el ejemplar depositado en B como lectotipo.

Alexeev (1984) usó la palabra "Typus" para indicar el material original en B para Festuca orthophylla var. meyenii, que aquí se corrige a lectotipo aplicando el Art. 9.9. Además se hallaron dos ejemplares en B, por lo tanto se hace una lectotipificación de segundo paso.

Existen varios duplicados de la colección de F. Philippi de la localidad tipo determinados por R. A. Philippi como F. juncea Phil. Entre ellos, se seleccionó el ejemplar SGO 63822 por corresponderse con las características del protólogo. El ejemplar citado como holotipo en Tropicos (www.mobot.org) y Catalán \& Müller (2012), SGO-Phil-294, no ha podido ser localizado en SGO.

Festuca orthophylla es un nuevo sinónimo para F. chrysophylla de acuerdo a los estudios del complejo "Festuca chrysophylla" del capítulo III de esta tesis. 
7. Festuca cirrosa (Speg.) Parodi, Revista Argent. Agron. 20(4): 190, f. 1B, B'. 1953. Festuca erecta var. cirrosa Speg., Anales Mus. Nac. Buenos Aires 5: 95. 1896. TIPO: ARGENTINA. Tierra del Fuego, Antártida e Islas del Atlántico Sur: Departamento Ushuaia, "Isla de los Estados, Puerto Roca", 1882, C. L. Spegazzini s.n. (holotipo LP 001474 ex LPS 276!). Figura 6.

Festuca longidiurna Parodi, Revista Argent. Agron. 20(4): 214. 1953. TIPO: ARGENTINA. Tierra del Fuego, Antártida e Islas del Atlántico Sur: Departamento Ushuaia, "Puerto Cook", 4 enero 1934, A. Castellanos s.n. (holotipo BA 12825!; isotipos BAA 1265!, SI 061810 (ex BA 12825)!).

Plantas densamente cespitosas, sin catafilos. Culmos floríferos $25-70 \mathrm{~cm}$ de alto, algunas veces con 1 nudo en la zona de entrenudos alargados, láminas mayormente basales. Vainas con la porción distal más ancha que la lámina, pajizas a verdosas, no lustrosas, membranáceas. Aurículas 0,8-1,2 mm de largo, con lóbulos redondeados, lisas, glabras, margen membranáceociliado. Pulvínulo de la vaina usualmente ausente, cuando presente glabro. Lígulas 1,5-3 mm de largo, ápice obtuso a retuso, margen membranáceo-entero. Láminas $17-35 \mathrm{~cm} \times 0,6-1,2$ $\mathrm{mm}$, conduplicadas, no rígidas, patentes, ápice pungente; superficie abaxial glabra; superficie adaxial esparcidamente escabrosa y cortamente pilosa. Panículas 5-13 cm de largo, lineares, contraídas; ramas adpresas al raquis, glabras. Espiguillas 12-18 $\mathrm{mm}$ de largo, con 4-7 antecios, verdosas, violáceas a pajizas; raquilla escabrosa y pobremente pilosa. Glumas iguales, escabrosas y pobremente pilosas hacia el ápice, con el nervio medio no conspicuo; gluma inferior 6-8 mm de largo, más larga que los $2 / 3$ del antecio adyacente, ápice acuminado, 1-nevia; gluma superior $8-10 \mathrm{~mm}$ de largo, más larga que $1 \mathrm{los}^{2} / 3$ del antecio adyacente, ápice agudo a acuminado, 3-nevias. Lemas del antecio basal 8-10 $\mathrm{mm}$ de largo (sin arista), escabrosas y cortamente pilosa en el ápice, ápice aristado, arista 3-5 mm de largo. Páleas con quillas ligeramente ciliadas. Lodículas $0,9-1,5 \mathrm{~mm}$ de largo, lobadas, margen eroso, glabras. Anteras 2-3,5 mm de largo. Ápice del ovario piloso.

Distribución y hábitat. Esta especie se distribuye desde $51^{\circ}$ hasta $55^{\circ} \mathrm{S}$, entre $0-175 \mathrm{~m}$ de altitud. Crecen exclusivamente en suelos arenosos y bancos de arena de costas marinas o lagunas en Chile (XII Región) y Argentina (Tierra del Fuego). Es un componente de las estepas graminosas en las provincias biogeográficas Altoandina (en el sur), Patagónica y Subantártica. Se encuentra distribuida en el sur del Cono Sur y con respecto a las demás especies, F. cirrosa, posee una distribución restringida. 
Observaciones. Festuca cirrosa se distingue de todas las especies de Festuca del Cono Sur por presentar lígulas de 1,5-3 $\mathrm{mm}$ de largo, de ápice obtuso a retuso, con láminas abaxialmente glabras y por sus glumas iguales. Se observaron ejemplares con espiguillas proliferadas: sin colector y sin número SI 619, 623, 625. Número cromosómico 2n = 42 (Dubcovsky \& Martínez 1987, 1991).

8. Festuca contracta Kirk, Trans. \& Proc. New Zealand Inst 27: 353. 1895. TIPO: AUSTRALIA. Tasmania: "Isla Macquarie", 1894, A. Hamilton s.n. (holotipo WELT 68607 imagen!). Figura 7.

Festuca erecta d'Urv., Fl. Iles Malouin. 4: 31. 1825. nom. illeg. hom., non F. erecta (Huds.) Wallr. 1822. LECTOTIPO: ARGENTINA. Tierra del Fuego, Antártida e Islas del Atlántico Sur, Islas Malvinas, "East Falkland Port Louis Iles Malounes, Malowines", 20 noviembre-18 diciembre 1822, J. d'Urville s.n. (lectotipo (de primer paso) P designado por Matthei (1982: 41) corregido de "typus", lectotipo (de segundo paso) P 00152248 imagen! designado por Ospina et al. (2015: 23); isolectotipos P 00625311 p.p. imagen!, P00625310 imagen!, MO 1837779 imagen!, US 2875404 (fragm. ex P) imagen!, foto CONC!).

Festuca paludicola Roiv., Ann. Bot. Soc. Zool.-Bot. Fenn. "Vanamo" 28(2): 200. 1954. TIPO: ARGENTINA. Tierra del Fuego, Antártida e Islas del Atlántico Sur: "Fuegia media, Estancia Los Cerros, in palude (No. 232)" (no localizado).

Plantas cespitosas, sin catafilos (ocasionalmente desarrolla cortos rizomas). Culmos floríferos 8-23 cm de alto, sin nudos en la zona de entrenudos alargados, láminas mayormente basales. Vainas con la porción distal más ancha que la lámina, pilosas en la zona distal, pajizas, lustrosas, membranáceas. Aurículas $0,3-0,5 \mathrm{~mm}$ de largo, lóbulos truncados, conspicuas, glabras, margen membranáceo-ciliado. Pulvínulo de la vaina ausente. Lígulas $0,6-1 \mathrm{~mm}$ de largo, ápice truncado, margen membranáceo-entero. Láminas $8-18 \mathrm{~cm} \times 0,5-0,8 \mathrm{~mm}$, conduplicadas, no rígidas, erectas, ápice obtuso; superficie abaxial glabra; superficie adaxial esparcidamente escabrosa y cortamente pilosa. Panículas 5-9 $\mathrm{cm}$ de largo, erectas, lineares, contraídas; ramas adpresas al raquis, escabrosas, esparcidamente pilosas. Espiguillas 7,5-13 $\mathrm{mm}$ de largo, con 2-4(-5) antecios, pajizas, verdosas a violáceas; raquilla escabrosa y pilosa. Glumas subiguales, escabrosas distalmente, con el nervio medio conspicuo; gluma inferior 5$11 \mathrm{~mm}$ de largo, más larga que los $2 / 3$ del antecio adyacente, ápice agudo, 1-nevia; gluma superior 6,5-9 mm de largo, más larga que los 2/3 del antecio adyacente, ápice agudo, 3-nevias. Lemas del antecio basal 4-7 mm de largo (sin arista), escabrosas distalmente, ápice aristado, 
arista 1-2 mm de largo. Páleas con quillas ligeramente escabrosas. Lodículas $0,7-1,3 \mathrm{~mm}$ de largo, lobadas, margen fimbriado, glabras. Anteras $0,8-1,5 \mathrm{~mm}$ de largo. Ápice del vario piloso.

Distribución y hábitat. Esta especie se distribuye desde $51^{\circ}$ hasta $54^{\circ} \mathrm{S}$, entre $200-1000 \mathrm{~m}$ de altitud. Crecen exclusivamente en suelos arenosos de las costas marinas o bancos de arena e islas en Chile (XII Región) y en Argentina (Tierra del Fuego e islas subantárticas). Además, se distribuye en Australia y Nueva Zelanda (Edgar \& Connor 2000). Es un componente de las estepas graminosas patagónicas en las provincias biogeográficas Altoandina (en el sur), Subantártica e Insular. Se encuentra distribuida en el sur del Cono Sur y con respecto a las demás especies, $F$. contracta, posee distribución geográfica restringida.

Observaciones. Festuca contracta se distingue de todas las especies del género Festuca del Cono Sur por presentar las glumas subiguales y por presentar lemas con aristas de 1-2 mm de largo. Número cromosómico 2n = 42 (Dubcovsky \& Martínez 1992).

9. Festuca dissitiflora Steud. ex Griseb., Abh. Königl. Ges. Wiss. Göttingen 24: 287. 1879. LECTOTIPO: ARGENTINA. Salta: sin departamento, Nevado del Castillo, 19-23 marzo 1873, P. G. Lorentz \& G. H. E. W. Hieronymus 71 (lectotipo B 100002575 imagen! aquí designado; isolectotipos BAA 00000377!, CORD 00004667!, CORD 00004668!, LIL 519023!, S S-R-2260 imagen!). Figura 8.

Festuca erecta var. aristulata Griseb., Abh. Königl. Ges. Wiss. Göttingen 19: 250. 1874. TIPO: ARGENTINA. Catamarca: sin departamento, "Im Hügellande bei Yakutula", febrero 1872, P. G. Lorentz 651 (holotipo GOET; isotipos CORD!, US 00516510!).

Festuca circinata Griseb., Abh. Königl. Ges. Wiss. Göttingen 24: 288. 1879. LECTOTIPO: ARGENTINA. Córdoba; Santa Rosa de Calamuchita: cerca de la Cuesta del Cerro, Sierra de Achala, 17 marzo 1876, G. H. E. W. Hieronymus 535 (lectotipo CORD 00004673! aquí designado; isolectotipos GOET, US 28765391 (fragm. ex GOET)!).

Festuca dissitiflora var. loricata Griseb., Abh. Königl. Ges. Wiss. Göttingen 24: 287. 1879. Festuca loricata (Griseb.) Pilg., Bot. Jahrb. Syst. 37: 515. 1906. Festuca dissitiflora subsp. loricata (Griseb.) St.-Yves, Candollea 3: 247. 1927. TIPO: ARGENTINA. Salta: sin departamento, "alrededores del Nevado del Castillo", 19-23 marzo 1873, P. G. 
Lorentz \& G. H. E. W. Hieronymus 68 (holotipo GOET; isotipos CORD 00004670, US 2875398 b (fragm. ex GOET)!).

Festuca dissitiflora var. villipalea St.-Yves, Candollea 3: 250. 1927. Festuca villipalea (St.Yves) E.B. Alexeev, Bot. Žurn. 70: 1244. 1985. TIPO: BOLIVIA. La Paz: provincia Palca, K. Pflanz 289 (holotipo B, isotipo S-05-5088!).

Plantas cespitosas, sin catafilos. Culmos floríferos (20-)25-40 cm de alto, con 2 nudos en la zona de entrenudos alargados, láminas mayormente basales. Vainas con la porción distal más ancha que la lámina, escabrosas, pajizas, no lustrosas, cartáceas. Aurículas $0,5-1 \mathrm{~mm}$ de largo, lobuladas y escariosas, conspicuas, esparcidamente escabrosa, el margen ciliolado. Pulvínulo de la vaina usualmente presente, piloso. Lígulas $1,5-2 \mathrm{~mm}$ de largo, ápice truncado, membranáceo-ciliado. Láminas $8-15(-23) \mathrm{cm} \times 1-1,5 \mathrm{~mm}$, conduplicadas, ligeramente rígidas, erectas a curvadas, ápice agudo a obtuso; superficie abaxial escabrosa y pilosa en la base; superficie adaxial escabrosa y esparcidamente pilosa. Panículas 6-10 cm de largo, lineares, contraídas; ramas adpresas al raquis, escabrosas. Espiguillas 6-7(-8) $\mathrm{mm}$ de largo, con 3-4(-5) antecios, verdosas a grisáceas con tintes violáceos; raquilla escabrosa. Glumas subiguales, escabrosas hacia el ápice, con el nervio medio conspicuo; gluma inferior 4-4,5 mm de largo, más larga que el 1/2 del antecio adyacente, ápice agudo, 1-nervia; gluma superior 5-5,5 mm de largo, $2 / 3$ o más cota que los $2 / 3$ del antecio adyacente, ápice acuminado, 3-nervia. Lemas del antecio basal 4-5 mm de largo (sin arista), escabrosa hacia el ápice, ápice bidentado y aristado, arista $0,8-1 \mathrm{~mm}$ de largo. Páleas con quillas ciliadas. Lodículas 1-1,5 mm de largo, lobadas, margen entero, glabras. Anteras 2,5-3 mm de largo. Ápice del ovario glabro.

Distribución y hábitat. Esta especie se distribuye desde $17^{\circ}$ hasta $28^{\circ} \mathrm{S}$, entre $1000-4500 \mathrm{~m}$ de altitud. Crece como plantas aisladas sobre las laderas rocosas de las montañas en Argentina (desde Salta hasta Mendoza). Además, se distribuye en Bolivia (La Paz, Oruro, Potosí y Tarija, Renvoize 1998) y Perú (Arequipa, Cerro de Pasco, Junín, Tovar 1972). Es característica de las estepas en la provincia biogeográfica Altoandina.

Observaciones. Esta especie se caracteriza por sus culmos floríferos con 2 nudos en la zona de entrenudos alargados, las vainas escabrosas y no lustrosas, sus lígulas de 1,5-2 mm de largo con el ápice truncado, membranáceo-ciliado, las láminas son erectas a curvadas con la superficie abaxial escabrosa y pilosa en la base, sus espiguillas son de 6-7(-8) $\mathrm{mm}$ de largo, con glumas subiguales y por sus lemas del antecio basal con ápice bidentado y aristado, arista 0,8-1 mm de largo. Número cromosómico 2n = 42, bajo F. circinata (Dubcovsky \& Martínez 1991). 
Notas nomenclaturales. Grisebach (1879: 287) cita la colección P. G. Lorentz \& $G$. Hieronymus 71 en el protólogo de F. dissitiflora. Catalán \& Müller (2012) citaron un ejemplar en GOET que no fue hallado, aunque existen más duplicados de esta colección. Se designa el ejemplar B 100002575 como lectotipo de $F$. dissitiflora ya que se encuentra bien preservado, lleva una etiqueta original y un dibujo del transcorte de la lamina.

En el protólogo de F. circinata, Grisebach (1879: 288) cita la colección "C.: S. Achala, cuesta del cerro". Se hallaron dos duplicados de Hieronymus 535 con esa información: CORD 00004673, que es un ejemplar completo con etiqueta original y otro en US (US 00513398) que es un fragmento ex GOET; el ejemplar en GOET no fue localizado. Se designa el ejemplar de CORD como lectotipo de $F$. circinata ya que es el ejemplar más completo, llevan la etiqueta original del autor y coincide con la información proporcionada sobre la localidad tipo del protólogo. La colección "Cerro champaquí, cerca del río del Catre, 30 ene 1877”, Hieronymus 783 (CORD 00004674, 00004675) es un probable sintipo.

10. Festuca distichovaginata Pilg., Bot. Jahrb. Syst. 37: 511. 1906. TIPO: PERÚ. Huánuco: sin departamento, "Huanuco, in provincia Huamalies, in montibus ad austrooccidentem a Monzon versus, frequentissima in graminosis hic illic uliginoses", 3700-3800 m, 10 julio 1903, A. Weberbauer 3317 (holotipo B 100002574 imagen!; isotipos US 00513483 (fragmento ex B) imagen!). Figura 9.

Festuca distichovaginata subvar. angustifolia St.-Yves, Candollea 3: 307. 1927. TIPO: ARGENTINA. Salta: Departamento Cafayate, "Sierra del Cajón, La Laguna", 27 enero 1914, D. Rodríguez 1324 (lectotipo BAA 00002007! aquí designado; isolectotipos, B, BAA 00002008!, BAA 00002012!, BAB 00000227!, BAF 00000116!, BAF 00000117!, LIL 000573 (fragmento ex B)!, LP 001473!, G, SI 001103!, SI 001104!, SI 001105! SI 001294!, US 00642137 imagen!, US 00133972 imagen!).

Plantas cespitosas, sin catafilos. Culmos floríferos $(45-) 50-75(-80) \mathrm{cm}$ de alto, con $1(-2)$ nudos en la zona de entrenudos alargados, láminas mayormente basales. Vainas con la porción distal más ancha que la lámina, glabras, pajizas a pardo-grisáceas al envejecer, no lustrosas, papiráceas a membranáceas. Aurículas ausentes. Pulvínulo de la vaina presente, piloso a glabrescente. Lígulas 2-2,5 mm de largo, ápice truncado a obtuso, a veces emarginado y con lóbulos obtusos, margen membranáceo-entero. Láminas $30-50 \mathrm{~cm} \times 0,15-0,25 \mathrm{~mm}$, rígidas, erectas, ápice mucronado y pungente; superficie abaxial escasamente escabrosa en la zona ligular; superficie adaxial esparcidamente escabrosa y pilosa. Panículas $12-17(-20) \mathrm{cm}$ de largo, lineares, contraídas; ramas adpresas al raquis, esparcidamente escabrosas. Espiguillas (9- 
)10-15 mm de largo, con 3-6 antecios, verdosas o con tintes violáceos; raquilla escabrosa y esparcidamente pilosa. Glumas subiguales, esparcidamente escabrosas, con el nervio medio no conspicuo; gluma inferior (3-)4,5-5,5 mm de largo, más larga que el 1/2 del antecio adyacente, ápice agudo, 1-nervia; gluma superior (5-)5,5-7 mm de largo, 2/3 o más corta que los $2 / 3$ del antecio adyacente, ápice agudo a estrechamente obtuso, 3-nervia. Lemas del antecio basal (6,5-)7-8.5 mm de largo (sin arista), esparcidamente escabrosas, ápice atenuado y aristado, arista 1-2 mm de largo. Páleas con quillas pilosas. Lodículas $0,5-1 \mathrm{~mm}$ de largo, lobadas, margen entero, glabras. Anteras 2,5-3 mm de largo. Ápice del ovario glabro.

Distribución y hábitat. Esta especie se distribuye desde $17^{\circ}$ hasta $24^{\circ} \mathrm{S}$, entre $3900-4100 \mathrm{~m}$ de altitud. Crece sobre las laderas rocosas de las montañas en forma de plantas aisladas, en Argentina (en Salta y Tucumán). También crece en Bolivia (La Paz, Potosí y Tarija, Renvoize 1998) y en Perú (Arequipa, Cerro de Pasco, Huánuco, Junín y Tacna, Tovar 1972). Es característica de las estepas de la provincia biogeográfica Altoandina.

Observaciones. Se distingue fácilmente de las especies de de Festuca del Cono Sur por presentar lígulas de 2-2,5 $\mathrm{mm}$ de largo, con el margen entero y el ápice truncado a obtuso y algunas veces emarginadas, las lemas son esparcidamente escabrosas.

Notas nomenclaturales. En el protólogo de Festuca distichovaginata subvar. angustifolia Saint Yves (1927: 307) citó dos sintipos: “Argentine. Prov. Salta: Sierra del Cajón, La Laguna, leg. Rodríguez, 27-I-1914, No 1324 bord des ruisseaux, 3900 m (herb. Par., herb St-Y)”. El material depositado en $\mathrm{G}$ no fue encontrado, pero se hallaron duplicados en otros herbarios. Por lo tanto, se designa el ejemplar BAA 00002007 como lectotipo de F. distichovaginata subvar. angustifolia por llevar la etiqueta original del autor y coincidir con la información sobre la localidad tipo del protólogo.

11. Festuca fiebrigii Pilg., Bot. Jahrb. Syst. 37: 510. 1906. LECTOTIPO: BOLIVIA. Tarija: sin provincia, "Bolivia autralis: prope vicum Pinos apud oppidium Tarija, in declivibus ad 2800 m”, K. A. G. Fiebrig 3118 (lectotipo BM 000938486 imagen! designado por E.B. Alexeev (1985: 1244); isolectotipos B 100002578 imagen!, BAA 0000164!, BAA 00000378!, BAA00000379!, G 00099488 imagen!, G 00099489 imagen!, K 000433598 imagen!, K 000433599 imagen!, S (S-R-2265) imagen!, S (S05-4823) imagen!, S (S05483) imagen!, US 000642139 imagen!). Figura 10. 
Plantas cespitosas, sin catafilos. Culmos floríferos $80-100 \mathrm{~cm}$ de alto, con 3-4 nudos en la zona de entrenudos alargados, láminas mayormente basales. Vainas con la porción distal no más ancha que la lámina, lisas, glabras, pajizas, lustrosas, membranáceas. Aurículas 1-1,5 mm de largo, lóbulos obtusos, conspicuas, esparcidamente pilosas, margen membranáceo-ciliado. Pulvínulo de la vaina ausente. Lígulas $1-1,5 \mathrm{~mm}$ de largo, ápice truncado, margen membranáceo-ciliado. Láminas $45-60 \mathrm{~cm} \times 2-3,5 \mathrm{~mm}$, conduplicada, no rígidas, decumbentes, ápice agudo a cortamente acuminado, pungente; superficie abaxial escabrosa, esparcidamente pilosa; superficie adaxial esparcidamente escabrosa. Panículas $35-45 \mathrm{~cm}$ de largo, lineares, contraídas; ramas adpresas al raquis, escabrosas. Espiguillas 9-11(-12) mm de largo, con 6-7 antecios, pajizas a verdosas; raquilla escabrosa y glabra. Glumas subiguales, escabrosas, con el nervio medio conspicuo; gluma inferior 3-3,8(-4) mm de largo, igual o más larga que los $2 / 3$ del antecio adyacente, ápice agudo, 1-nervia; gluma superior 4-5 mm de largo, más larga que los $2 / 3$ del antecio adyacente, ápice agudo, 3-nervia. Lemas del antecio basal 4-5 mm de largo, escabrosas, ápice estrechamente obtuso y algunas veces mucronado. Páleas con quillas ciliadas. Lodículas $0,6-1 \mathrm{~mm}$ de largo, lobadas, margen entero, glabras. Anteras 1-2 mm de largo. Ápice del ovario gabro.

Distribución y hábitat. Esta especie se distribuye desde $20^{\circ}$ hasta $28^{\circ} \mathrm{S}$, entre $2200-3000 \mathrm{~m}$ de altitud. Crece sobre las laderas rocosas de las montañas en Argentina (desde Salta hasta Mendoza). Además, se distribuye en Bolivia (La Paz, Oruro, Potosí y Tarija, Renvoize 1998) y Perú (Arequipa, Cerro de Pasco, Junín y Tacna, Tovar 1972). Es característica de las estepas en la provincia biogeográfica Altoandina.

Observaciones. Especie similar a $F$. hieronymi pero se diferencia por sus culmos floríferos de 33-55 cm de alto, laminas de 20-35 cm × 2,5-3,5 mm, erectas a curvadas, con el ápice largamente setáceo y no pungente.

12. Festuca fimbriata Nees, Fl. Bras. Enum. Pl. 2(1): 472. 1829. TIPO: BRASIL [URUGUAY]. Sin departamento: "Habitat ad Monte-video", F. Sellow s.n. (holotipo B 10 0002567!, isotipos B 10 0002568!, HAL 0107005!, LE 00000731 !, LE 00000732 (ex B)!, US 557541 (ex B)!, US 1441522 (ex B)!, US 1126679 (fragm. ex W)!, W 18890252147!). Figura 11.

Festuca ampliflora Döll, Fl. Bras. 2(3): 116. 1878. LECTOTIPO: BRASIL. Estado Minaru [Minas Gerais]: "Habitat in prov. Minarum", febrero 1846, J. Regnell III 1409 (lectotipo 
S [S04-1260] designado por E.B. Alexeev (1984: 348), isolectotipos S [S04-1259]!, P 00625301 !).

Plantas rizomatosas, con catafilos. Culmos floríferos $100-150(-180) \mathrm{cm}$ de alto, con 3-4 nudos en la zona de entrenudos alargados, láminas a lo largo de los culmos. Vainas con la porción distal no más ancha que la lámina, lisas, glabras, pajizas, no lustrosas, papiráceas. Aurículas ausentes. Pulvínulo de la vaina ausente. Lígulas 1,5-2 mm de largo, ápice truncado, margen cortamente membranáceo y densamente piloso. Láminas $30-40(-50) \mathrm{cm} \times 4,5-5,5$ $\mathrm{mm}$, planas, a convolutas, no rígidas, erectas, ápice atenuado; superficie abaxial y adaxial escabrosa. Panículas (25-)30-45 cm de largo, oblongo-lanceoladas, laxas; ramas erectas y flexuosas dispuestas en seudoverticilos con 2-3(-4) ramas, marcadamente escabrosas. Espiguillas 18-25 mm de largo, con (8-)9-12 antecios marcadamente imbricados, verdosas; raquilla escabrosa. Glumas subiguales, escabrosas en el dorso y pilosas en el ápice, con los nervios conspicuos; gluma inferior 6-8,5 mm de largo, más larga que el 1/2 del antecio adyacente, ápice agudo, 3-5-nevia; gluma superior 7-9 mm de largo, igual o más larga que los 2/3 del antecio adyacente, ápice obtuso, 3-5-nevias. Lemas del antecio basal 8-10 mm de largo, escabrosas, ápice agudo a atenuado. Páleas con quillas pilosas. Lodículas 1-2 mm de largo, lobadas, margen fimbriado, fimbrias de 0,25 mm de largo, esparcidamente pilosa. Anteras 2-3 $\mathrm{mm}$ de largo. Ápice del ovario piloso.

Distribución y hábitat. Esta especie se distribuye desde $20^{\circ}$ hasta $30^{\circ} \mathrm{S}$, entre $0-2000 \mathrm{~m}$ de altitud. Crece en las sabanas serranas y las zonas más bajas de los matorrales y de la selva en Argentina (Corrientes y Misiones), en Brasil (Minas Gerais, Paraná, Río de Janeiro, Río Grande do Sul, Santa Catarina). Además, Stančík \& Peterson (2007) y Rúgulo et al. (2008) la citan para Paraguay (Caazapá, Itapúa) y Uruguay (Tacuarembó). Es un componente importante de las sabanas de gramíneas de la provincia biogeográfica Paranense.

Observaciones. Esta especie se diferencia fácilmente por presentar láminas planas, con la lígula cortamente membranácea y densamente pilosa, con espiguillas 18-25 mm de largo, con (8-)912 antecios marcadamente imbricados y sus lodículas fimbriadas (fimbrias de 0,25 $\mathrm{mm}$ de largo). Número cromosómico 2n = 42 (Dubcovsky \& Martínez 1992).

13. Festuca gracillima Hook. f., Fl. Antarct. 2: 383. 1847. LECTOTIPO: CHILE. XII Región: sin provincia, "Strait of Magalhaens, Port Famine", A. Anderson s.n. in Cap. King exped. (lectotipo K 000433665 imagen! designado por Matthei (1982: 30) corregido de 
"typus"; isolectotipos BM 000938488 imagen!, P 00625313 imagen!, US 2875418 (fragm. ex K) imagen!). Figura 12.

Clave para las variedades de F. gracillima (tomada y modificada de Rúgolo de Agrasar \& Nicora 1988).

1. Anteras 3-4,5 mm de largo; flores casmogamas; en pastizales var. gracillima

$1^{\prime}$. Anteras $0,7-1 \mathrm{~mm}$ de largo; flores cleistógamas; en suelos helados var. glacialis

\section{a. var. gracillima}

Festuca gracillima var. brevifolia Speg., Anales Mus. Nac. Buenos Aires 5: 95. 1896. NEOTIPO: CHILE. XII Región: sin provincia, "Hab. Semel tantum in dunis maritimis: Gente Grande Bay", 1882, C. L. Spegazzini s.n. [neotipo LP 001476 (ex LPS 14320)! designado por Rúgolo de Agrasar \& Nicora (1988: 466)].

Plantas densamente cespitosas, sin catafilos. Culmos floríferos $15-45 \mathrm{~cm}$ de alto, usualmente sin nudos en la zona de entrenudos alargados, láminas mayormente basales. Vainas con la porción distal más ancha que la lámina, glabras, pajizas a marrones, lustrosas, membranáceas. Aurículas $0,2-0,3 \mathrm{~mm}$ de largo, lóbulos truncados, inconspicuas, glabras, margen membranáceo-ciliado. Pulvínulo de la vaina ausente. Lígulas 0,5-0,6 $\mathrm{mm}$ de largo, ápice truncado, margen membranáceo-entero. Láminas $(5-) 8-18 \mathrm{~cm} \times 0,5-0,8 \mathrm{~mm}$, conduplicadas, no rígidas, erectas, ápice rostrado; superficie abaxial glabra; superficie adaxial cortamente pilosa. Panículas 6-12 $\mathrm{cm}$ de largo, lineares, contraídas; reducidas a racimos (pedicelos de las espiguillas sobre el raquis), raramente espiguillas sobre ramas de segundo orden. Espiguillas 12-20 mm de largo, con 4-6 antecios no imbricados, pajizas, verdosas a violáceas; raquilla escabrosa y glabra. Glumas desiguales, pobremente escabrosas distalmente y sobre los nervios, con el nervio medio conspicuo; gluma inferior 4-7 mm de largo, igual o más larga que el 1/3 del antecio adyacente, ápice acuminado, 1-nevia; gluma superior 6-9 mm de largo, más corta que $\operatorname{los} 2 / 3$ del antecio adyacente, ápice obtuso, 3-nevias. Lemas del antecio basal 7-10(-11) mm de largo (sin arista), distalmente escabrosas, ápice aristado, arista 2-5 $\mathrm{mm}$ de largo; nervio medio conspicuo. Páleas con quillas ligeramente ciliadas. Lodículas 1-1,8 mm de largo, lobadas, margen eroso, glabras. Anteras $0,7-4,5 \mathrm{~mm}$ de largo. Ápice del ovario piloso.

Distribución y hábitat. Este taxón se distribuye desde $49^{\circ}$ hasta $51^{\circ} \mathrm{S}$, entre $0-900 \mathrm{~m}$ de altitud. Crece en suelos rocosos y laderas de colinas bajas o cerca cuerpos de agua y forma matas aisladas en los campos con presencia de nieve temporal, en Chile (XII Región) y en Argentina 
(Santa Cruz y Tierra del Fuego). Es un componente de las estepas de las provincias biogeográficas Patagónica y Subantártica. Se encuentra distribuida en el sur del Cono Sur y con respecto a las demás especies, Festuca gracillima var. gracillima, posee distribución geográfica restringida.

Observaciones. Entre las especies del género Festuca del Cono Sur, esta variedad se caracteriza por sus láminas flácidas (no rígidas), espiguillas con antecios no imbricados y con las lemas aristadas. Algunos especímenes provenientes de Chile muestran espiguillas y ramas en primer y segundo orden, pero en los que provienen de Argentina las espiguillas se ubican mayormente en ramas de primer orden. Número cromosómico 2n = 42 (Dubcovsky \& Martínez 1991).

b. var. glacialis Rúgolo \& Nicora, Bol. Soc. Argent. Bot. 25: 464. 1988. TIPO: ARGENTINA. Santa Cruz: Departamento Güer Aike, "Ea. Stag River, Meseta La Torre, Co. Punta

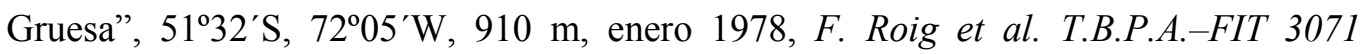
(holotipo BAB no encontrado, isotipo SI 061806!). Figura 13.

Distribución y hábitat. Esta variedad se distribuye desde $49^{\circ} \mathrm{S}$ hasta $51^{\circ}$, entre $0-1300 \mathrm{~m}$ de altitud. Crecen en suelos criófilos, en Chile (XII Región) y en Argentina (Santa Cruz). Se encuentra en las mismas provincias fitogeográficas de la variedad tipo; asimismo, se distribuye en el sur del Cono Sur y con respecto a las demás especies, Festuca gracillima var. glacialis, posee distribución geográfica restringida.

14. Festuca hieronymi Hack., Oesterr. Bot. Z. 53: 33. 1903. LECTOTIPO: ARGENTINA. Córdoba: Departamento Calamuchita, "Sierra de Achala ad Quebrado del Chorro al Este de los Gigantes; Sierra Chica de Córdoba ad Colanchanga", 4 diciembre 1878, G. H. E. W. Hieronymus 9 (lectotipo W 1916-0004736 imagen!, designado por E. B. Alexeev (1984: 351); isolectotipos B 100002593 imagen!, B 100002596 imagen!, BAA 00000364!, BAA 00000364!, BAA 00000167!, CORD 00001642!, CORD 00001643!). Figura 14.

Festuca erecta var. mutica Griseb., Abh. Königl. Ges. Wiss. Göttingen 19: 250. 1874. LECTOTIPO: ARGENTINA. Catamarca: sin departamento, "Catamarca inconvalle Granadillas pr. Yacutula", febrero 1872, P. G. Lorentz 532 (lectotipo B 100002629 imagen! aquí designado; isolectotipos CORD, US 2875399 imagen!). 
Festuca hieronymi subvar. expansa St.-Yves, Candollea 3: 254. 1927. Festuca hieronymi var. expansa (St.-Yves) Türpe, Darwiniana 15: 242. 1969. LECTOTIPO: ARGENTINA. Tucumán: "Dpto. Tafí: Cuesta de Anfama, prados, 12 febrero 1905”, M. Lillo 3993 (lectotipo CORD 00001648! designado por Türpe (1969: 242), isolectotipos LIL 000131!, W1916-0004740 imagen!).

Plantas cespitosas, sin catafilos. Culmos floríferos $35-55 \mathrm{~cm}$ de alto, con 1 nudo en la zona de entrenudos alargados, láminas mayormente basales. Vainas con la porción distal no más ancha o igual de ancha que la lámina, escabrosas, pardas a grisáceas al envejecer, no lustrosas, cartáceas. Aurículas 0,5-0,8 mm de largo, lóbulos obtusos a truncados, conspicuas, escabrosas, margen eroso. Pulvínulo de la vaina presente, liso, esparcidamente piloso. Lígulas 0,5-1 mm de largo, ápice truncado, margen eroso. Láminas $20-35 \mathrm{~cm} \times 2,5-3,5 \mathrm{~mm}$, planas, a convolutas, no rígidas, erectas a curvadas, ápice largamente setáceo, no pungente; superficie abaxial escabrosa; superficie adaxial densamente escabrosa y esparcidamente pilosa. Panículas 18-25(-30) cm de largo, lanceoladas, contraídas; ramas erectas a raramente adpresas al raquis, escabrosas y glabras. Espiguillas 7-8 mm de largo, con 3-4(-5) antecios, violáceas a verdosas; raquilla escabrosa, glabra. Glumas desiguales, escabrosas, con el nervio medio no conspicuo; gluma inferior 3-3,5(-3,8) mm de largo, igual o más larga que el 1/2 del antecio adyacente, ápice acuminado, 1-nervia; gluma superior 5-5,5 mm de largo, más larga que $10 \mathrm{~s} 2 / 3$ del antecio adyacente, ápice agudo, 3-nervia. Lemas del antecio basal (6-)7-9 mm de largo, escabrosas hacia el ápice y el dorso, ápice acuminado. Páleas con quillas ciliadas. Lodículas 1-1,5 mm de largo, lobadas, margen eroso, glabras. Anteras 3-3,5 mm de largo. Ápice del ovario glabro.

Distribución y hábitat. Esta especie se distribuye desde los $30^{\circ}$ hasta $33^{\circ} \mathrm{S}$, entre $400-3000 \mathrm{~m}$ de altitud. Crece en laderas pedregosas en las altas montañas de la cordillera de los Andes y forma praderas cerca a cuerpos de agua en Argentina (de Córdoba hasta Salta). Es un componente característico y de abundancia significativa en las estepas graminosas de las provincias biogeográficas Altoandina y Puna.

Observaciones. Se puede separar fácilmente de las especies de Festuca del Cono Sur, por sus láminas planas (pero que se enrrollan en seco), con el ápice largamente setáceo, las aurículas de margen eroso y por sus glumas desiguales en longitud. Es comúnmente confundida con $F$. fiebrigii (ver observaciones de este taxón) y con $F$. parodii que se diferencia por presentar glumas iguales o más largas que los antecios adyacentes y espiguillas con 2(-3) antecios. Número cromosómico 2n = 42 (Dubcovsky \& Martínez 1992). 
Notas nomenclaturales. Grisebach (1874) señala distintas colecciones en la descripción de $F$. erecta var. mutica: Lechler 3004 (GOET, no vista), Philippi 569 (no hallada) y una colección sin más datos que la localidad ("Catamarca inconvalle Granadillas pr. Yacutula"). Se selecciona el ejemplar B 100002629 como lectotipo de este nombre porque está en buen estado, lleva los datos de la localidad mencionada por Grisebach y corresponde con la breve descripción de la variedad.

Türpe (1969: 242) selecciona como ejemplar tipo de Festuca hieronymi subvar. expansa la colección Lillo 3993 conservada en CORD. Otro sintipo para este nombre es Lorentz \& Hieronymus 736 (CORD).

15. Festuca hypsophila Phil., Verz. Antofagasta Pfl. 89. 1891. Festuca deserticola var. hypsophila (Phil.) Saint-Yves, Candollea 3: 210. 1927. LECTOTIPO: CHILE. I Región: Provincia Tarapacá, Ad Colorados, Leoncito, Ampexa, Huasco frequens, c. 3800 m, F. Philippi s.n. (lectotipo SGO (de primer paso) designado por Matthei (1982: 46), corregido de "typus", lectotipo (de segundo paso) SGO 063821!, designado por Ospina et al. (2015: 29); isolectotipos B 100002633 imagen!, SGO 062723!, SGO 037423!, LP 290537!, US 556550 (fragm. ex SGO)!, W 19160039744 imagen!, W 19160004743 imagen!]. Figura 15.

Plantas densamente cespitosas, sin catafilos. Culmos floríferos $40-90 \mathrm{~cm}$ de alto, con 1-2 nudos en la zona de entrenudos alargados, láminas mayormente basales. Vainas con la porción distal igual o ligeramente más ancha que la lámina, glabras, pajizas a blanquecinas, lustrosas, membranáceas. Aurículas inconspicuas, margen membranáceo-ciliado. Pulvínulo de la vaina presente, esparcidamente piloso. Lígulas $0,3-0,5 \mathrm{~mm}$ de largo, ápice truncado, margen membranáceo-ciliado. Láminas $13-40 \mathrm{~cm} \times 0,8-1 \mathrm{~mm}$, conduplicadas, rígidas, erectas, ápice pungente a rostrado; superficie abaxial glabra; superficie adaxial escabrosa y cortamente pilosa. Panículas 8-16(-20) cm de largo, lineares, contraídas; ramas adpresas al raquis, pobremente escabrosas. Espiguillas 10-15 mm de largo, con 4-5 antecios, pajizas a verdosas; raquilla escabrosa. Glumas subiguales, escabrosas en dorso y ápice, cortamente pilosas hacia el ápice, con el nervio medio conspicuo; gluma inferior 3-6 mm de largo, más larga que el $1 / 2$ del antecio adyacente, ápice acuminado, 1-nevia; gluma superior 4-7 mm de largo, más corta que los 2/3 del antecio adyacente, ápice agudo, 3-nevias. Lemas del antecio basal 7-9 $\mathrm{mm}$ de largo (sin arista), escabrosas sobre los nervios y porción distal, ápice aristado, arista 1-2 mm de largo (caduca). Páleas con quillas ciliadas. Lodículas $0,5-1 \mathrm{~mm}$ de largo, lobadas, margen entero, glabras. Anteras 1,5-2,5 mm de largo. Ovario ápice glabro. 
Distribución y hábitat. Esta especie se distribuye desde $21^{\circ}$ hasta $29^{\circ} \mathrm{S}$, entre $3200-4800 \mathrm{~m}$ de altitud. Crece en suelos arenosos o rocosos, en laderas de altas montañas, cerca de los cuerpos de agua y en campos con presencia de nieve temporal, en Chile (desde la Región I hasta III) y en Argentina (desde Salta hasta San Juan). Además, se distribuye en Bolivia (La Paz, Potosí y Tarija) y Perú (Arequipa, Cerro de Pasco, Junín y Tacna) según Türpe (1969), Tovar (1972), Renvoize (1998) y Catalán \& Müller (2012). Es un componente florístico característico en las estepas graminosas de las provincias biogeográficas Altoandina y del Desierto.

Observaciones. Se puede distinguir fácilmente de las especies del Cono Sur por sus vainas lustrosas, papiráceas a membranáceas, las aurículas inconspicuas y la presencia del pulvínulo de la vaina, así como por sus lígulas truncadas, de 0,3-0,5 $\mathrm{mm}$ de largo. Esta especie es similar a F. chrysophylla (ver las observaciones de dicho taxón).

16. Festuca kurtziana St.-Yves, Candollea 3: 201, f. 31. 1927. LECTOTIPO: ARGENTINA. Mendoza: Departamento Malargüe, "Cordillera de Malalhue, Baños Viejos", febrero 1892, F. Kurtz s.n., herb. Arg. N. 7196 (lectotipo B 100002588 imagen! designado por Matthei (1982: 41) corregido de "typus"; isolectotipos CORD 00001649!, CORD 00001650!, CORD 00001651!, CORD 00001652!, CORD 00001653!, CORD 00001654!, CORD 00001655!). Figura 16.

Plantas densamente cespitosas, sin catafilos. Culmos floríferos $30-65 \mathrm{~cm}$ de alto, con 1-2 nudos en la zona de entrenudos alargados, láminas mayormente basales. Vainas con la porción distal más ancha que la lámina, corta y densamente pilosas en la porción distal, pajizas a comúnmente violáceas, lustrosas, membranáceas. Aurículas $0,5-0,8 \mathrm{~mm}$ de largo, conspicuas, con lóbulos obtusos, glabras, margen membranáceo y cortamente ciliado. Pulvínulo de la vaina usualmente presente, glabro. Lígulas $0,4-0,7 \mathrm{~mm}$ de largo, ápice truncado, margen membranáceo y cortamente ciliado. Láminas $8-16 \mathrm{~cm} \times 1-1.3 \mathrm{~mm}$, conduplicadas, rígidas, divergentes a patentes, algunas veces recurvadas, ápice rostrado; superficie abaxial glabra a cortamente pilosa en la base; superficie adaxial pobremente escabrosa y densamente pilosa. Panículas 8-13(-15) cm de largo, lineares, usualmente laxas; ramas ascendentes, esparcidamente escabrosas. Espiguillas 11-14 mm de largo, con 4-6 antecios, pajizas a verdosas, alguna veces con tintes violáceos; raquilla esparcidamente escabrosa. Glumas subiguales, escabrosas hacia el ápice, con el nervio medio conspicuo; gluma inferior 4-6 mm de largo, más larga que el 1/2 del antecio adyacente, ápice agudo, 1-nevia; gluma superior 5-6 mm de largo, más corta que los $2 / 3$ del antecio adyacente, ápice agudo, 3-nevias. Lemas del antecio 
basal 7,5-11 mm (sin arista), escabrosas en la porción distal, ápice acuminado o aristado, arista 0,5-1,5 mm de largo. Páleas con quillas ciliadas. Lodículas $0,7-1 \mathrm{~mm}$ de largo, lobadas, margen eroso, glabras. Anteras 2,5-4 mm de largo. Ápice del ovario piloso.

Distribución y hábitat. Esta especie se distribuye desde $33^{\circ}$ hasta $38^{\circ} \mathrm{S}$, entre $1600-2800 \mathrm{~m}$ de altitud. Crece en laderas de las altas montañas en la cordillera de los Andes y en campos con presencia de nieve temporal, en Chile (Región Metropolitana y VII Región) y en Argentina (de Mendoza hasta Neuquén). Es un componente florístico de las estepas graminosas en las provincias biogeográficas Altoandina y Chile central.

Observaciones. Esta especie es similar a Festuca acanthophylla var. acanthophylla, pero difiere por sus láminas divergentes a patente (a veces curvadas), con ápice rostrado, por las panículas de 8-13(-15) cm de largo, con espiguillas con 4-6 antecios; mientras que en $F$. acanthophylla var. acanthophylla las láminas son erectas y con el ápice pungente, las panículas de (6-)9-28 cm de largo, con espiguillas con 5-8 antecios. Comúnmente conocido como “coirón braco" o "pasto clavador". Número cromosómico 2n = 42 (Dubcovsky \& Martínez 1991).

Notas nomenclaturales. En B se halló un único ejemplar de F. Kurtz s.n., herb. Arg. N. 7196 y se considera como el lectotipo seleccionado por Matthei (1982). Otro sintipo es mencionado en el protólogo de Festuca kurtziana: Río Negro, Gussfeldt s.n. (no localizado).

17. Festuca lasiorrhachis Pilg., Bot. Jahrb. Syst. 37: 508. 1906. Festuca laeteviridis var. lasiorrhachis (Pilg.) St.-Yves, Candollea 3: 239. 1927. LECTOTIPO: PERÚ. Puno: sin departamento, "supra Cuyocuyo, in herbaceis, fruticibus intermixtis", 3700-3800 m, 3 mayo 1902, A. Weberbauer 904 (lectotipo BAA 00000866 (fragmento ex B)! designado por Nicora (1998: 267); isolectotipos B100002584 imagen!, S S-R1-2282 (fragmento ex B) imagen!).

Plantas cespitosas, sin catafilos. Culmos floríferos 70-100(-150) $\mathrm{cm}$ de alto, con 2-3 nudos en la zona de entrenudos alargados, láminas mayormente basales. Vainas con la porción distal distalmente más ancha que la lámina, pilosas, pajizas a marrones, ligeramente lustrosas, papiráceas o membranáceas. Aurículas $05-0,8 \mathrm{~mm}$ de largo, inconspicuas, con lóbulos obtusos, glabras, margen eroso. Pulvínulo de la vaina presente, piloso. Lígulas $0,5-1 \mathrm{~mm}$ de largo, ápice truncado, margen eroso, glabras. Láminas (10)15-35(40) $\mathrm{cm} \times 2-6 \mathrm{~mm}$, conduplicadas, 
no rígidas, erectas a patentes, ápice agudo, no pungente; superficie abaxial glabra, lisa; superficie adaxial cortamtne pilosa. Panículas 18-25(-30) $\mathrm{cm}$ de largo, lineares, contraídas, raquis densamente villoso-pubescente; ramas adpresas a patentes, densamente villosopubescentes. Espiguillas 9-15 mm de largo, con 6-7 antecios, verdosas y con tintes violáceos; raquilla villoso-pubescente. Glumas subiguales, escabrosas hacia el ápice, con el nervio medio conspicuo; gluma inferior 4,5-5,5(-6) mm de largo, igual o más larga que el 1/2 del antecio adyacente, ápice agudo, 1-nervia; gluma superior (5,5-)6-7 mm de largo, más larga que los 2/3 del antecio adyacente, ápice agudo a obtuso, 3-nervia. Lemas del antecio basal 6,5-7,5(-8) mm de largo, escabrosas, ápice atenuado. Páleas con quillas ciliado-pubescentes. Lodículas 11,5 mm de largo, lobadas, margen entero, glabras. Anteras $2-4 \mathrm{~mm}$ de largo. Ápice del ovario glabro.

Iconografía. Nicora, Hickenia 2(57): 268, fig. 1. 1998.

Distribución y hábitat. Esta especie se distribuye desde $20^{\circ}$ hasta $25^{\circ} \mathrm{S}$, entre $2800-3400 \mathrm{~m}$ de altitud. Crece en laderas pedregosas y de fuertes pendientes formando franjas de matas grandes en la cordillera de la los Andes, en Argentina (Jujuy y Salta) y en Chile (II Región). Además, se distribuye en Bolivia (La Paz y Potosí, Renvoize 1998) y en Perú (Ayacucho, Cuzco, Lima y Puno, Tovar 1972). Es un componente característico de las estepas graminosas de los Andes en las provincias biogeográficas Altoandina, del Desierto y Puneña. Con respecto a otras especies, Festuca lasiorrhachis, posee distribución geográfica restringida.

Observaciones. Esta especie se diferencia fácilmente de las especies del Cono Sur por sus ramas y raquis villoso-pubescentes. No obstante, este taxón fue referido por Hitchcock (1927) como F. dolichophylla y considerada por Catalán \& Müller (2012) como sinónimo de $F$. dolichophylla, la cual, difiere por tener el raquis y ramas de la panícula glabras o esparcidamente escabrosas sobre los nervios, lámina con superficie adaxial escabrosa. Además, F. dolichophylla se excluye para la flora del Cono sur en este trabajo (ver especies excluidas) y por lo tanto, se restaura este nombre para la flora de Sudamérica y para el Cono Sur.

Notas nomenclaturales. Pilger (1906) menciona tres sintipos de Perú para F. lasiorrhachis: Weberbauer 904, 907 y 589. Nicora (1998: 267) señala erroneamente que el ejemplar de B se destruyó y selecciona como lectotipo el fragmento de BAA ex B. 
18. Festuca lilloi Hack., Annuaire Conserv. Jard. Bot. Genéve 17: 300. 1914. Festuca setifolia var. lilloi (Hack.) St.-Yves, Candollea 3: 217. 1927. LECTOTIPO: ARGENTINA. Tucumán: Departamento Lara, "Lara”, alt 3200 m, 25 enero 1912, Rodríguez 287 [Lillo 11142, Stuckert 22459] (lectotipo W 19160039161 imagen! aquí designado; isolectotipos, SI 003903!, SI 003902!, LIL 44120!, US 91412 (ex W) imagen!, US 172488 imagen!, US 1816090 imagen!). Figura 17.

Festuca lilloi var. breviaristata Türpe, Darwiniana 15: 231, 1969. LECTOTIPO: ARGENTINA. Tucuman: Departamento Tafi, Cuesta de Anfama, 2600 m, 12 febrero 1903, M. Lillo 3992 (lectotipo LIL 000062! aquí designado, isolectotipo CORD 00001656!).

Plantas cespitosas, sin catafilos. Culmos floríferos $25-45 \mathrm{~cm}$ de alto, con 3 nudos en la zona de entrenudos alargados, láminas mayormente basales. Vainas con la porción distal no más anchas o igual de ancha que la lámina, escabrosas, pajizas, lustrosas, membranáceas. Aurículas ausentes. Pulvínulo de la vaina presente, liso, esparcidamente piloso. Lígulas 2,5-3(-3,5) $\mathrm{mm}$ de largo, ápice emarginado y con dos lóbulos agudos, margen eroso. Láminas $10-15 \mathrm{~cm} \times 1,5-$ $2 \mathrm{~mm}$, conduplicadas, no rígidas, circinadas a flexuosas, ápice atenuado, no pungente; superficie abaxial escabrosa; superficie adaxial esparcidamente pilosa. Panículas $11-15 \mathrm{~cm}$ de largo, lineares, contraídas; ramas patentes, escabrosas y cortamente pilosas. Espiguillas 6-7,5 mm de largo, con 3-4 antecios, violáceas a pajizas; raquilla escabrosa y glabra. Glumas subiguales, escabrosas, con el nervio medio conspicuo; gluma inferior 3,5-4 mm de largo, más larga que el $1 / 2$ del antecio adyacente, ápice agudo, 1-nervia; gluma superior 3,8-4,5 mm de largo, más corta que $\operatorname{los} 2 / 3$ del antecio adyacente, ápice obtuso, 3-nervia. Lemas del antecio basal 4,8-5,5 mm de largo, esparcidamente escabrosas en el ápice, ápice agudo. Páleas con quillas pilosas. Lodículas $0,5-1 \mathrm{~mm}$ de largo, lobadas, margen entero, glabras. Anteras 3-3,5 mm de largo. Ápice del ovario piloso.

Distribución y hábitat. Esta especie se distribuye desde $24^{\circ}$ hasta $26^{\circ} \mathrm{S}$, entre $2300-3900 \mathrm{~m}$ de altitud. Crece cerca de cuerpos de agua y en laderas rocosas de las montañas de los Andes en Argentina (Salta y Tucumán). Es un componente florístico escaso en las estepas andinas de las provincias biogeográficas Puneña y Altoandina, posee distribución geográfica restringida.

Observaciones. Esta especie se caracteriza por sus culmos floríferos de $25-45 \mathrm{~cm}$ de alto, con 3 nudos en la zona de entrenudos alargados, aurículas ausentes y pulvínulo de la vaina presente, sus lígulas son de 2,5-3(-3,5) mm de largo, con el ápice emarginado y con lóbulos agudos, margen eroso y por sus espiguillas $6-7(-7,5) \mathrm{mm}$ de largo con 3-4 antecios. Número cromosómico 2n = 56 (Dubcovsky \& Martínez 1992). 
Notas nomenclaturales. Todos los duplicados de Rodríguez 287 están determinados por Hackel, por lo tanto se consideran sintipos y es necesaria una lectotipificación. Los isotipos SI 003903, SI 003902, LIL 44120, US 172488 y US 1816090 tiene como fecha de colección 28-I1912, posiblemente debido a un error al transcribir las etiquetas.

Türpe (1969) menciona dos ejemplares en el protólogo de Festuca lilloi var. breviaristata como "typus varietatis", por lo tanto se selecciona aquí un lectotipo.

19. Festuca magellanica Lam., Encycl. 2: 461. 1788. Festuca ovina var. magellanica (Lam.) Hack., Svenska Exped. Magell. 3(5): 228. 1900. Festuca ovina subsp. magellanica (Lam.) St.-Yves, Candollea 3: 163. 1927. LECTOTIPO: ARGENTINA. Sin Provincia: “Magellan”, octubre 1767, P. Commerson s.n. (lectotipo [quizás holotipo] P 00625315 foto! designado por Matthei (1982: 33) corregido de "typus"; isolectotipos US 91403 foto!, MPU 013897 foto!). Figura 18.

Festuca ovina var. antarctica Hack., Svenska Exped. Magell. 3(5): 228. 1900. LECTOTIPO: ARGENTINA. Sin provincia: "Fuegia orientalis, Río Cullen", 1891, B. Ansorge 490 (lectotipo [quizás holotipo] S 1324505 foto! designado por Matthei (1928: 33) corregido de "typus"; isolectotipos W, US 00624214 (fragm. ex W) foto!).

Festuca ovina subsp. hystricola Hack., Ark. Bot. 7(2): 10. 1907. Festuca hystricola (Hack.) E. B. Alexeev (1984: 352). LECTOTIPO: ARGENTINA. Santa Cruz: departamento Magallanes, "Puerto San Julián in campo ad Santa Cruz emporium in campo", 19 diciembre 1904, P. K. H. Dusén 5389 (lectotipo [quizás holotipo] S (SR 2291) imagen! designado por Matthei (1982: 33) corregido de "typus"; isolectotipos W 19160008149 foto, US 3412269 foto].

Festuca ovina var. wilczekii St.-Yves, Candollea 3: 168. 1927. LECTOTIPO: ARGENTINA. Mendoza: departamento San Rafael, "environs de St-Raphael et de la vallée du Río Atuel, Piedra del Burrero", 3000 m, sin fecha, E. Wilczek 572 (lectotipo G 00099498 ex LAU imagen! designado por Ospina et al. (2015: 34); isolectotipo G 00099497foto).

Festuca rubra subsp. corcovadensis St.-Yves Candollea 3: 291. 1927. LECTOTIPO: ARGENTINA. Chubut: departamento Futaleufú, “Corcovado”, 1900, N. Illin s.n., Herb. L. R. Parodi 1877 (lectotipo G 00099482 foto! designado por Ospina et al. (2015: 34); isolectotipo BAA, SI 061815!). 
Plantas cespitosas, sin catafilos. Culmos floríferos 10-40 cm de alto, con 1-2 nudos en la zona de entrenudos alargados, láminas mayormente basales. Vainas con la porción distal más ancha que la lámina, esparcidamente pilosas, pajizas, lustrosas, membranáceas. Aurículas $0,5-0,8 \mathrm{~mm}$ de largo, lóbulos truncados, esparcidamente escabrosas, margen membranáceo-ciliado. Pulvínulo de la vaina presente, piloso. Lígulas $0,5-1 \mathrm{~mm}$ de largo, ápice truncado, margen membranáceo-entero. Láminas $8-12 \mathrm{~cm} \times 0,5-1 \mathrm{~mm}$, conduplicadas, no rígidas, erectas, ápice agudo; superficie abaxial glabra; superficie adaxial pilosa. Panículas $2,5-8 \mathrm{~cm}$ de largo, lineares, contraídas, usualmente reducidas a racimos (pedicelos de las espiguillas sobre el raquis). Espiguillas 4-10 $\mathrm{mm}$ de largo, con 3-5 antecios, pajizas a verdosas, algunas veces con tintes violáceos; raquilla pobremente escabrosa. Glumas subiguales, lisas, usualmente glabras, con el nervio medio no conspicuo; gluma inferior 2,5-4,5 mm de largo, más larga que el 1/2 del antecio adyacente, ápice agudo, 1-nevia; gluma superior 5-6 mm de largo, más corta que los $2 / 3$ del antecio adyacente, ápice obtuso, 3-nervia. Lemas del antecio basal 5-6 mm de largo (sin arista), pobremente escabrosa en el ápice, ápice aristado, arista 1-2 mm de largo. Páleas con quillas ciliadas. Lodículas $0,5-1 \mathrm{~mm}$ de largo, lobadas, margen fimbriado, glabras. Anteras 0,5-1 mm de largo. Ápice del ovario glabro.

Distribución y hábitat. Esta especie se distribuye desde $33^{\circ}$ hasta $52^{\circ} \mathrm{S}$, entre $0-3500 \mathrm{~m}$ de altitud. Crecen en suelos arenosos y costas marinas o lagunas en Chile (XII Región) y en Argentina (desde Mendoza hasta Tierra del Fuego). Es un componente importante de las estepas graminosas en las provincias biogeográficas Altoandina (en el sur), Subantártica y Patagónica, más freceunte desde Chubut hasta Tierra del Fuego.

Observaciones. Es comúnmente confundida con $F$. pyrogea, que se diferencia por las lemas densamente pilosas y escabrosas y las glumas escabrosas en el ápice. Número cromosómico $2 \mathrm{n}$ = 42, 46 (Dubcovsky \& Martínez 1992).

Notas nomenclaturales. St.-Yves (1927: 292) cita dos ejemplares de la colección "Patagonie Territoire du Chubut au Río Corcovado, Pierna Illin 1900 (herb. Par. et herb. St-Y.)" como tipo para F. rubra subsp. corcovadensis. Designamos el ejemplar G 00099482 como lectotipo.

Saint-Yves (1927: 168, 309) cita dos sintipos de Festuca ovina var. wilczekii de San Rafael, Mendoza: "vallée du Río Atuel, Piedra del Burrero, E. Wilczek 572" (LAU) y "Cerro Nevado, 3000 m, Macola s.n., Herb. L. R. Parodi 7287” (BAA). Se hallaron dos duplicados de Wilczek 572 en G y designo como lectotipo el ejemplar G 00099498. 
20. Festuca monticola Phil., Anales Univ. Chile 43: 576. 1873. Festuca gracillima var. monticola (Phil.) St.-Yves, Candollea 3: 178. 1927. LECTOTIPO: CHILE. XIV Región: Provincia Valdivia, "Cordillera Pelada de la Prov. Valdivia", enero 1872, F. Philippi s.n. (lectotipo (de primer paso) SGO designado por Matthei (1982: 56-57) corregido de "typus", lectotipo (de segundo paso) SGO 037419! designado por Ospina et al. (2015: 36); isolectotipos SGO 063838!, SGO 037418, SGO 062718!, BAA 00002054 (ex K)!, BAA 1271!, LP 034792!, LP 007999!). Figura 19.

Festuca subandina Phil., Anales Univ. Chile 94: 177. 1896. LECTOTIPO: CHILE. XIV Región: Provincia Valdivia, "Andes de Valdivia, Boquete de Trancura", febrero 1887, O. Philippi s.n. (lectotipo (de primer paso) SGO designado por Matthei (1982: 57) corregido de "typus", lectotipo (de segundo paso) SGO 037434! designado por Ospina et al. (2015: 36); isolectotipos B 100186533 imagen!, BAA 1340 ex SGO!, BAA 1339 ex B!, CORD 1662!, CORD 1657!, K000433673 imagen!, SGO 63843!).

Plantas densamente cespitosas, sin catafilos. Culmos floríferos (25-)40-65 $\mathrm{cm}$ de alto, sin nudos en la zona de entrenudos alargados, láminas mayormente basales. Vainas con la porción distal más anchas que la lámina, glabras, pajizas, lustrosas, membranáceas. Aurículas 0,3-0,6 $\mathrm{mm}$ de largo, inconspicuas, glabras, margen entero. Pulvínulo de la vaina usualmente presente, glabro. Lígulas 0,3-0,8(-1) $\mathrm{mm}$ de largo, ápice truncado, margen entero. Láminas 6-20 cm $\times$ 1-1,8 mm, conduplicadas, rígidas, erectas a recurvadas, ápice pungente; superficie abaxial glabra, brillante; superficie adaxial glabra y con papilas. Panículas $8-16 \mathrm{~cm}$ de largo, lanceoladas, laxas; ramas ascendentes a patentes, escabrosas y esparcidamente pilosas. Espiguillas 10-15 mm de largo, con 3-5 antecios, verdosas y violáceas; raquilla escabrosa. Glumas subiguales, escabrosas en el ápice, glabras, con el nervio medio conspicuo; gluma inferior 4-4,7 $\mathrm{mm}$ de largo, más larga que el 1/2 del antecio adyacente, ápice agudo, 1-nevia; gluma superior 5-6,5 mm de largo, más corta que $10{ }^{2} / 3$ del antecio adyacente, ápice obtuso, 3nevias. Lemas del antecio basal 9-10 $\mathrm{mm}$ de largo (sin arista), o 10-15 $\mathrm{mm}$ en espiguillas proliferadas, pobremente escabrosas, ápice aristado, arista 1,5-2,5(-2,8) $\mathrm{mm}$ de largo. Páleas con quillas escabrosas. Lodículas 0,5-1 mm de largo, lobadas, margen entero, glabras. Anteras 3-4 mm de largo. Ápice del ovario glabro.

Distribución y hábitat. Esta especie se distribuye desde $37^{\circ}$ hasta $51^{\circ} \mathrm{S}$, entre $500-1550 \mathrm{~m}$ de altitud. Crecen exclusivamente en suelos arenosos y costas marinas en Chile (desde laVIII a laXIV Región) y en Argentina (Neuquén). Es un componente escaso en las estepas graminosas 
de las provincias biogeográficas Altoandina (en el sur), Patagónica y Subantártica. Posee distribución geográfica restringida.

Observaciones. Se diferencia fácilmente de otras especies de Festuca por sus láminas foliares glabras y por la presencia de papilas en la cara adaxial. Algunos ejemplares presentan espiguillas proliferadas: Ruthsatz 7810 (SI), Moore et al. s.n. T.B.P.A. 2026 (SI). Número cromosómico 2n = 42 (Dubcovsky \& Martínez 1991).

Notas nomenclaturales. Los especímenes K 000433673, CORD 1657 y B100186533 fueron citados como material tipo de $F$. monticola por Muñoz-Pizarro (1960) y Catalán \& Müller (2012), pero corresponden a $F$. subandina.

21. Festuca nardifolia Griseb., Abh. Königl. Ges. Wiss. Göttingen, Math.-Phys. K1. 24: 286. 1879. LECTOTIPO: ARGENTINA. Salta: sin departamento, "Alrededores del Nevado del Castillo, in humidis et Nivem aeternam, alt. 15000", 19-23 marzo1873, P. G. Lorentz \& G. Hieronymous 84 (lectotipo GOET designado por Matthei (1982: 38) corregido de "typus"; isotipos B10 0002631!, CORD 00004666!, LIL 459128! (ex CORD 00004666), US 91896 (fragm. ex GOET)). Figura 20.

Festuca calchaquiensis Hack., Anales Mus. Nac. Buenos Aires 13: 520. 1906. Festuca nardifolia var. calchaquiensis (Hack.) St.-Yves, Candollea 3: 171. 1927. TIPO: ARGENTINA. Tucumán: departamento Tafí del Valle, "Cumbres Calchaquíes, en la vecindad de la nieve eterna”, 4 febrero 1903, J. V. Stuckert Herb. arg. 15373 ex Lillo herb. tuc. 3073 (holotipo W 19160004704 !; isotipos CORD 00001638, LIL 44086!, US 91393(fragm. ex W)).

Plantas densamente cespitosas, sin catafilos. Culmos floríferos (3)5-6(8) $\mathrm{cm}$ de alto, sin nudos en la zona de entrenudos alargados, láminas mayormente basales. Vainas con la porción distal más ancha que la lámina, pilosas, pajizas y con tintes rojizos, papiráceas y fibrosas al envejecer. Aurículas $0,4-1 \mathrm{~mm}$ de largo, lóbulos truncados a obtusos, conspicuas, esparcidamente escabrosas, margen membranáceo-ciliado. Pulvínulo de la vaina usualmente presente, glabro. Lígulas 0,3-1,2 mm de largo, ápice truncado, margen membranáceo-ciliado. Láminas 1-4(-6) $\mathrm{cm} \times 0,3-0,7 \mathrm{~mm}$, conduplicadas, rígidas, recurvadas a patentes, ápice acuminado, pungente; superficie abaxial usualmente esparcidamente escabrosa; superficie adaxial cortamente pilosa. Panículas 1-3(-4,5) mm de largo, lineares, erectas, contraídas; ramas adpresas al raquis, esparcidamente escabrosas. Espiguillas 4-6 mm de largo, con 3-5 antecios, pajizas a verdosas; raquilla esparcidamente escabrosa. Glumas subiguales, escariosas, esparcidamente pilosas en el 
ápice, con el nervio medio conspicuo; gluma inferior (4-)4,5-5 $\mathrm{mm}$ de largo, más larga que el $1 / 2$ del antecio adyacente, ápice agudo, 1-nevia; gluma superior 5-6(-6,5) $\mathrm{mm}$ de largo, más corta que $\operatorname{los} 2 / 3$ del antecio adyacente, ápice agudo a ligeramente obtuso, 3-nevias. Lemas del antecio basal 4,5-6mm de largo ( $\sin$ arista), escabrosas, ápice acuminado a cortamente aristado, arista de 0,4-0,7 mm de largo. Páleas con quillas ciliadas. Lodículas $0,3-0,5 \mathrm{~mm}$ de largo, lobadas, margen entero, glabras. Anteras 1-2 mm de largo. Ápice del ovario glabro.

Distribución y hábitat. Esta especie se distribuye desde $24^{\circ}$ hasta $29^{\circ} \mathrm{S}$, entre $3900-5000 \mathrm{~m}$ de altitud. Crece formando cojines cerca a los cuerpos de agua de las montañas de los Andes en Argentina (Salta hasta San Juan). Es un componente florístico de abundancia significativa en las estepas andinas de las provincias bioogeográficas Puneña y Altoandina. En este trabajo se excluye a $F$. nardifolia de Chile y se restringe su distribución a la Argentina, constituyendo un endemismo para ese país.

Observaciones. Como se mencionó en "Novedades corológicas", Festuca nardifolia fue descripta originalmente para Argentina sobre la base de ejemplares de 5-7 cm de alto, de matas muy densas, subpulvinadas, de cañas floríferas e inflorescencias cortas, pauciespigadas, espiguillas 3-4 floras, lemas algo escabrosas hacia el ápice, con ápice agudo. Luego, otros autores (entre ellos Matthei 1982 y Catalán \& Müller 2012) amplian el concepto de esta especie e incluyen ejemplares de Argentina y Chile de mayor altura, con láminas e inflorescencias más largas. Sin embargo, estos ejemplares corresponden a individuos de Festuca rigescens. Ambas especies son morfológicamente afines, sin embargo, pueden distinguirse por los caracteres morfológicos de citados en la clave en el apartado "Novedades corológicas". Por lo tanto, circunscribimos aquí el concepto morfológico de $F$. nardifolia a lo descripto en el protólogo de la especie, se excluye de Chile y se restringe su distribución a la Argentina.

Notas nomenclaturales. De acuerdo a Taxonomic Literature (Stafleu et al. 1976-1988), Grisenbach estudió material en préstamo además de sus tipos depositados en GOET, por lo tanto se considera necesaria la lectotipificación inferencial de Matthei (1982).

22. Festuca nemoralis Türpe, Darwiniana 15: 213. 1969. LECTOTIPO: ARGENTINA. Tucumán: departamento Tafí del Valle, "La Ciénaga", $2800 \mathrm{~m} 5$ febrero 1933, L. R. Parodi 11049 (holotipo BAA 00000170!; isotipos, LIL505103!, US1539751 imagen!). Figura 21. 
Plantas rizomatosas, con catafilos. Culmos floríferos $100-150 \mathrm{~cm}$ de alto, con 2-3 nudos en la zona de entrenudos alargados, láminas a lo largo de los culmos. Vainas con la porción distal no más anchas que las láminas, glabras, pajizas, lustrosas, membranáceas y fibrosas. Aurículas ausentes. Pulvínulo de la vaina ausente. Lígulas 3-4 mm de largo, ápice obtuso a redondeado, con margen membranáceo en la base y dentado-ciliado en el ápice. Láminas (30-)35-50 cm × 4-5,5 mm, planas, a convolutas, no rígidas, sub-erectas a curvadas, ápice atenuado; superficie abaxial escabrosa; superficie adaxial pilosa. Panículas $(20-) 25-30 \mathrm{~cm}$ de largo, oblongolanceoladas, laxas; ramas dispuestas en seudoverticilos con 3-5 ramas, flexuosas, marcadamente escabrosas. Espiguillas 10-14 mm de largo, con 7-9 antecios marcadmanete imbricados, verdosas; raquilla esparcidamente escabrosa. Glumas subiguales, escabrosas solamente en el dorso, con todos los nervios conspicuos; gluma inferior 4-5,5 mm de largo, más larga que los 2/3 del antecio adyacente, ápice agudo, 3-nevia; gluma superior (4,7-)5-6,5 mm de largo, más larga que los $2 / 3$ del antecio adyacente, ápice obtuso, 3-nevia. Lemas del antecio basal (6-)6,5-7,8 mm de largo (sin arista), escabrosas, ápice mucronado a aristado, arista de 1$1.7 \mathrm{~mm}$ de largo. Páleas con quillas ciliadas. Lodículas 1-2 mm de largo, lobadas, margen fimbriado, fimbrias de 0,25 mm de largo. Anteras 2,5-3 mm de largo. Ápice del ovario piloso.

Distribución y hábitat. Esta especie se distribuye desde $20^{\circ}$ hasta $30^{\circ} \mathrm{S}$, entre $1000-3000 \mathrm{~m}$ de altitud. Crece en suelos inundados de las sabanas del bosque altoandino caducifolio en Argentina (Jujuy). Es un componente importante de los prados graminosos de la provincia biogeográfica de las Yungas.

Observaciones. Se diferencia fácilmente por sus láminas planas, la lígula con margen membranáceo en la base y dentado-ciliado en el ápice, por sus espiguillas 10-14 mm de largo, con 6-9 antecios marcadamente imbricados y sus lodículas fimbriadas (fimbrias de 0,25 $\mathrm{mm}$ de largo). Número cromosómico 2n = 56 (Dubcovsky \& Martínez 1992).

23. Festuca ovina subsp. tenuifolia (Sibth.) Čelak., Prodr. Fl. Böhmen 1: 50. 1867. Festuca tenuifolia Sibth., Fl. Oxon.: 44. 1794. Festuca ovina var. tenuifolia (Sibth.) Roem. \& Schult., Syst. Veg. (ed. 15 bis) 2(2): 714. 1817. LECTOTIPO: INGLATERRA. Sin estado: "Dry Pastures. Bullington Green Oxonii", Pluk. Alm. tab. 34. f. 2 (lectotipo OXF designado por Auquier (1970: 4)). Figura 22.

Plantas cespitosas, sin catafilos. Culmos floríferos 10-40 cm de alto, con 1-2 nudos en la zona de entrenudos alargados, láminas mayormente basales. Vainas con la porción distal más anchas 
que la lámina de las hojas, esparcidamente pilosas, pajizas, lustrosas, membranáceas. Aurículas 0,4-0,6 mm de largo, lóbulos redondeados inconspicuas, glabras, margen membranáceo-ciliado. Pulvínulo de la vaina presente, piloso. Lígulas $0,5-1 \mathrm{~mm}$ de largo, ápice truncado, margen membranáceo-ciliado. Láminas $8-12 \mathrm{~cm} \times 0,5-1 \mathrm{~mm}$, conduplicadas, no rígidas, erectas, ápice agudo; superficie abaxial glabra; superficie adaxial pilosa. Panículas $2,5-8 \mathrm{~cm}$ de largo, lineares, contraídas, usualmente reducidas a racimos (pedicelos de las espiguillas sobre el raquis). Espiguillas 4-10 mm de largo, con 3-5 antecios, pajizas a verdosas, algunas veces con tintes violáceos; raquilla pobremente escabrosa. Glumas desiguales, glabras, con el nervio medio inconspicuo; gluma inferior 2,5-4,5 mm de largo, igual o más corta que el 1/3 del antecio adyacente, ápice agudo, lisas, 1-nevia; gluma superior 5-6 mm de largo, más larga que el 1/2 del antecio adyacente, ápice obtuso, 3-nevia. Lemas del antecio basal 5-6 $\mathrm{mm}$ de largo, pobremente escabrosa en el ápice, glabra, ápice obtuso. Páleas con quillas ciliadas. Lodículas 0,5-1 mm de largo, lobadas, margen entero, glabra. Anteras $0,5-1 \mathrm{~mm}$ de largo. Ápice del ovario glabro.

Distribución y hábitat. Especie introducida. Se distribuye en áreas templado-frías de Eurasia y se ha introducido en América del Sur y del Norte. En Argentina (Santa Cruz) se distribuye a $35^{\circ} \mathrm{S}$, entre 0-600 $\mathrm{m}$ de altitud de acuerdo con Catalán \& Müller (2012). Es común encontrarla en la estepa patagónica y en la provincia Subantártica.

Observaciones. Los taxones del complejo $F$. ovina presentan amplia variación morfológica y se han descripto numerosos taxones infraespecificos, entre los cuales, es necesario establecer límites taxonómicos con herramientas moleculares o estudios poblacionales. Esta variedad es la única citada para el Cono Sur, para la cual se hallaron escasos materiales de estudio.

24. Festuca pallescens (St.-Yves) Parodi, Revista Argent. Bot. 20(4): 206, f. 4. 1953. Festuca gracillima subvar. pallescens St.-Yves, Candollea 3: 296. 1927. LECTOTIPO: ARGENTINA. Santa Cruz: Departamento Güer Aike, "ad Río Coyle, estancia Las Vegas", 3 diciembre 1916, A. Dauber 173 [Herb. Parodi 2917] (lectotipo BAA 1234! designado por Parodi (1953: 206); isolectotipo BAA 1235!). Figura 23.

Festuca gracillima var. patagonica Speg., Revista Fac. Agron. Vet. La Plata 3(30-31): 586. 1897. LECTOTIPO: ARGENTINA. Santa Cruz: departamento Güer Aike, "in dunis maritimis ad ostia Río Gallegos", 1882, C. L. Spegazzini s.n. (lectotipo LP 12640! 
designado por Rúgolo \& Nicora (1988: 467), corregido de "holotipo"; isolectotipo SI $61807 !)$.

Festuca gracillima var. ramosa St.-Yves, Candollea 3: 177. 1927. LECTOTIPO: ARGENTINA. Santa Cruz: sin departamento, "Patagonie, Pescadores pres Santa Cruz", 25 diciembre 1904, P. K. H. Dusén 5443 (lectotipo SI 061805! designado por Ospina el al. (2015: 39).

Festuca gracillima fo. scabra St.-Yves, Candollea 3: 296. 1927. Festuca pallescens var. scabra (St.-Yves) Parodi, Revista Argent. Agron. 20: 210. 1953. LECTOTIPO: ARGENTINA. Neuquén: Departamento Picunches, "Pino Hachado", febrero 1920, L. R. Parodi 3190 (lectotipo G 00386429 imagen! designado por Ospina el al. (2015: 39); isolectotipo BAA 1294!).

Festuca pallescens var. foliosa Parodi, Revista Argent. Agron.20: 210. 1953. TIPO: ARGENTINA. Chubut: Departamento Languiñeo, "Estancia Pampa Chica, $60 \mathrm{~km}$ al oeste de Tecka", 23 enero 1947, A. Soriano 2464 (holotipo BAA 1291!; isotipo SI $120240 !)$

Festuca pallescens var. grandiflora Parodi, Revista Argent. Bot. 20(4): 211. 1953. Festuca magniflora E. B. Alexeev, Bot. Žhurn. (Moscow \& Leningrad) 69: 351. 1984, non Festuca grandiflora Lam. 1791, non Steud. 1854. TIPO: ARGENTINA. Chubut: Departamento Futaleufú, "Corcovado", enero 1900, N. Illin s.n. (holotipo BAA 1292 (Herb. Parodi 1879)!).

Plantas densamente cespitosas, sin catafilos, raramente con cortos rizomas. Culmos floríferos 50-60(-70) cm de alto, con 1-2 nudos en la zona de entrenudos alargados, láminas mayormente basales. Vainas con la porción distal más ancha que la lámina, glabras, pajizas, lustrosas, membranáceas. Aurículas ausentes. Pulvínulo de la vaina presente, conspicuo, glabro. Lígulas 0,5-0,8 mm de largo, ápice truncado, margen membranáceo-entero. Láminas 8-15(-18) cm $\times$ 1,5-2 mm, conduplicadas, rígidas, divergentes, ápice pungente a rostrado; superficie abaxial glabra; superficie adaxial pobremente escabrosa, corta y densamente pilosa. Panículas 4-15(17) $\mathrm{cm}$ de largo, lineares, contraidas, con ramas de segundo orden o superior, raramente reducidas a racimos (pedicelos de las espiguillas sobre el raquis). Espiguillas 12-19 mm de largo, con 4-6 antecios, verdosas a pajizas; raquilla pobremente escabrosa y pilosa. Glumas subiguales, escasamente escabrosas y pilosas en el margen y ápice, con el nervio medio no conspicuo; gluma inferior 4-5,5 mm de largo, más larga que el 1/2 del antecio adyacente, ápice acuminado, 1-nervia; gluma superior 6-7 mm de largo, más corta que los $2 / 3$ del antecio adyacente, ápice acuminado, 3-nevia. Lemas del antecio basal 6,5-8,5 $\mathrm{mm}$ de largo (sin 
arista), esparcidamente escabrosas, ápice aristado, arista 1,5-3,5 $\mathrm{mm}$ de largo, esparcidamente escabrosas. Páleas con quillas ciliadas. Lodículas $0,8-1 \mathrm{~mm}$ de largo, lobadas, margen eroso, glabras. Anteras 1,8-3,5 mm de largo. Ápice del ovario piloso.

Distribución y hábitat. Este taxón se distribuye desde $47^{\circ} \mathrm{S}$ hasta $52^{\circ}$, entre $0-900 \mathrm{~m}$ de altitud. Crece en bancos de arena cercanos a cuerpos de agua y en forma de matas aisladas en los campos con presencia de nieve temporal en Chile (XII Región) y Argentina (Río Negro hasta Tierra del Fuego). Es un componente característico y abundante de la estepa patagónica y en la provincia Subantártica.

Observaciones. Esta especie se confunde comúnmente con $F$. gracillima var. gracillima, pero se distingue por su mayor tamaño $(50-60(-70) \mathrm{cm}$ de alto), por sus láminas de 1,5-2 $\mathrm{mm}$ de ancho, rígidas y divergentes (vs. plantas de $15-45 \mathrm{~cm}$ de alto, láminas foliares de 0,5-0,8 $\mathrm{mm}$ de ancho, no rígidas y erectas en $F$. gracillima var. gracillima). Festuca pallescens se conoce comúnmente como "coirón dulce" o "coirón blanco". Número cromosómico $2 \mathrm{n}=42$ (Dubcovsky y Martínez 1987, 1991).

Notas nomenclaturales. Entre los sintipos de Festuca gracillima var. ramosa, el especímen SI 061805 es selecionado como lectotipo porque está bien preservado y concuerda con el protólogo. Los otros sintipos: "Santa Cruz au lac Puyrredon" y "Santa Cruz au Rio Fenix, Exp. suec", ambos Skottsberg s.n., no fueron localizados en B (Robert Vog, comunicación personal).

Saint-Yves (1927) cita dos ejemplares de la colección original de L. R. Parodi 3190 de $F$. gracillima fo. scabra: Herb. Parodi (BAA) y herb. St-Y (G), por ello se designa un lectotipo.

25. Festuca pampeana Speg., Contr. Fl. Sierra Vent. 73. 1896. TIPO: ARGENTINA. Buenos Aires. Partido Tornquist: "hallada una sola vez en abundancia en la Falda occidental del Cerro de la Ventana", noviembre 1895, C. L. Spegazzini s.n. [12539] (holotipo LP 001490 !). Figura 24.

Plantas cespitosas, sin catafilos. Culmos floríferos 50-70 cm de alto, con 1(-2) nudos en la zona de entrenudos alargados, láminas mayormente basales. Vainas con la porción distal no más ancha o igual de ancha que la lámina, espa rcidamente escabrosas, pajizas, no lustrosas, papiráceas y fibrosas. Aurículas ausentes. Pulvínulo de la vaina ausente. Lígulas 1-2 mm de largo, ápice obtuso, margen membranáceo-ciliado. Láminas $20-25(-30) \mathrm{cm} \times 1-3 \mathrm{~mm}$, conduplicadas, no rígidas, erectas a decumbentes, ápice atenuado a acuminado, pungente; 
superficie abaxial marcadamente escabrosa; superficie adaxial esparcidamente pilosa. Panículas 13-16(-20) cm de largo, lineares, contraídas; ramas adpresas al raquis, escabrosas y cortamente pilosas. Espiguillas 11-13 $\mathrm{mm}$ de largo, con 6-8 antecios, violáceas a pajizas; raquilla escabrosa. Glumas subiguales, escabrosas en el dorso y ápice, con el nervio medio conspicuo; gluma inferior 4-5 mm de largo, igual o más larga que el 1/3 del antecio adyacente, ápice agudo, 1-nervia; gluma superior 5,5-6,5 $\mathrm{mm}$ de largo, igual o más corta que el $1 / 2$ del antecio adyacente, ápice obtuso, 3-nervia. Lemas del antecio basal 7-8,5 mm de largo, escabrosas en el dorso, ápice agudo a obtuso. Páleas con quillas ciliadas. Lodículas $0,8-1,5 \mathrm{~mm}$ de largo, lobadas, margen entero, glabras. Anteras 2,5-3 mm de largo. Ápice del ovario piloso.

Distribución y hábitat. Esta especies de distribuye desde $37^{\circ}$ hasta $39^{\circ}$, entre $500-1000 \mathrm{~m}$ de altitud. Crece en suelos esquistos y laderas rocosas en el sistema montañoso de Sierra de la Ventana y Sierras de Cura Malal, al sur de la provincia de Buenos Aires.

Observaciones. Comparte el área de distribución con $F$. ventanicola, pero esta especie presenta cañas de 30-40(-45) cm de alto, aurículas conspicuas, láminas de (8-)10-18 cm de largo y lemas aristadas. Número cromosómico 2n $=56$ (Dubcovsky \& Martínez 1988).

26. Festuca panda Swallen, J. Wash. Acad. Sci. 26(5): 209. 1936. TIPO: CHILE. IV Región: Provincia de Choapa," Illapel, Cajón de los Pelambres", enero 1932, G. Looser 2151 (holotipo US 1614378 imagen!). Figura 25.

Plantas densamente cespitosas, sin catafilos. Culmos floríferos $20-30 \mathrm{~cm}$ de alto, con 2-3 nudos en la zona de entrenudos alargados, láminas mayormente basales. Vainas con la porción distal más ancha que la lámina, esparcidamente pilosas, pajizas a rojizas, membranáceas. Aurículas $0,7-1 \mathrm{~mm}$ de largo, lóbulos obtusos a truncados, conspicuas, esparcidamente escabrosas, margen entero. Pulvínulo de la vaina usualmente presente, piloso. Lígulas $0,3-0,5$ $\mathrm{mm}$ de largo, ápice truncado, margen entero. Láminas 2-4(-6) $\mathrm{cm} \times 1-2 \mathrm{~mm}$, rígidas, patentes a recurvadas, ápice obtuso; superficie abaxial glabra; superficie adaxial escabrosa y cortamente pilosa. Panículas 3-4(-6) cm de largo, linear, geniculadas a péndulas, contraídas; ramas adpresas al raquis, esparcidamente escabrosas. Espiguillas 6-9 mm de largo, con 3-4(-5) antecios, pajizas a verdosas; raquilla escabrosa. Glumas desiguales, esparcidamente pilosas en el margen, con el nervio medio conspicuo; gluma inferior 1,5-2 mm de largo, más corta que el 1/2 del antecio adyacente, ápice agudo, 1-nevia; gluma superior 3,5-4 mm de largo, igual o más larga que $\operatorname{los} 2 / 3$ del antecio adyacente, ápice obtuso, 3-nevia. Lemas del antecio basal 5-6,5 
mm de largo, escabrosas distalmente, ápice obtuso a agudo. Páleas con quillas ciliadas. Lodículas 0,4-0,8 $\mathrm{mm}$ de largo, lobadas, margen entero, glabras. Anteras 1,5-2,5 $\mathrm{mm}$ de largo. Ápice del ovario glabro.

Distribución y hábitat. Esta especie se distribuye desde $29^{\circ}$ hasta $30^{\circ} \mathrm{S}$, entre $2900-3400 \mathrm{~m}$ de altitud. Crece formando cojines cerca de los cuerpos de agua y en laderas rocosas de las altas montañas de los Andes en Chile (IV Región). Es un componente abundante en las estepas graminosas de las provincias biogeográficas Puna y del Desierto. Festuca panda posee una distribución geográfica restringida y es endémica de Chile.

Observaciones. Se diferencia fácilmente de otras especies de Festuca del cono Sur por tamaño pequeño con numerosas innovaciones estériles, también por presentar láminas $2-4(-6) \mathrm{cm}$ de largo, usualmente rígidas, por las panículas geniculadas a péndulas y sus lemas tienen el ápice obtuso a agudo y sin arista.

27. Festuca parodiana (St.-Yves ex Parodi) Nicora, Hickenia 2(57): 267. 1998. Festuca subulata var. parodiana St.-Yves ex Parodi, Physis (Buenos Aires) 11: 499. 1935. LECTOTIPO: ARGENTINA. Tucumán: sin departamento, "San José, común en el bosque de aliso", 2100 m, 26 enero 1933, L. R. Parodi 10698 (lectotipo G 00099478! designado por Nicora (1998: 267); isolectotipo LIL 504657!). Figura 26.

Plantas rizomatosas, con catafilos. Culmos floríferos 115-120(-130) cm de alto, con 6-7(-8) nudos en la zona de entrenudos alargados, láminas a lo largo de los culmos. Vainas con la porción distal no más ancha que la lámina, pilosas, verdosas a pajizas, no lustrosas, papiráceas a membranáceas. Aurículas ausentes. Pulvínulo de la vaina ausente. Lígulas 1,5-2,5 mm de largo, ápice truncado, margen membranáceo-eroso. Láminas (30-)40-50 cm × 8-11 mm, planas, a convolutas, no rígidas, decumbentes, ápice agudo, no pungente; superficie abaxial marcadamente escabrosa; superficie adaxial esparcidamente escabrosa. Panículas 15-25(-30) $\mathrm{cm}$ de largo, ampliamente lanceoladas, laxas; ramas patentes y flexuosas, esparcidamente escabrosas. Espiguillas (9-)10-12 mm de largo, con 2-3(-4) antecios, verdosas; raquilla esparcidamente escabrosa. Glumas desiguales, glabras, con el nervio medio no conspicuo; gluma inferior 1-1,5(-2) mm de largo, más corta que el 1/3 del antecio adyacente, ápice agudo, 1-nevia; gluma superior (4-)5-6 mm de largo, igual o más larga que el 1/2 del antecio adyacente, ápice agudo, 3-nevia. Lemas del antecio basal 6-7(-7,5) $\mathrm{mm}$ de largo, esparcidamente escabrosa en el ápice, ápice agudo a subulado. Páleas con quillas escabrosas. Lodículas 0,5-1 
$\mathrm{mm}$ de largo, lobadas, margen entero, glabras. Anteras 1-2 mm de largo. Ápice del ovario piloso.

Distribución y hábitat. Esta especie se distribuye desde $20^{\circ}$ hasta $30^{\circ} \mathrm{S}$, entre $2000-2900 \mathrm{~m}$ de altitud. Crece formando plantas aisladas cerca de los cuerpos de agua y según Catalán \& Müller (2012) crece sobre suelos silíceos, en Argentina (desde Salta hasta San Juan). Es característica de las Yungas y, en parte, de la provincia Altoandina. También crece en Bolivia.

Observaciones. Se diferencia fácilmente de otras especies de Festuca del Cono Sur por sus glumas desiguales y con los nervios no conspicuos, por la gluma inferior de $1-1,5(-2) \mathrm{mm}$ de largo, más corta que el 1/3 del antecio adyacente, con ápice agudo y 1-nervia.

28. Festuca parodii St.-Yves., Candollea 3: 308. 1927. LECTOTIPO: ARGENTINA. Catamarca: sin departamento, "Poman", diciembre 1909, L. R. Parodi 2342 (lectotipo BAA 00000175! aquí designado; isolectotipo LIL 505358!). Figura 27.

Plantas cespitosas, sin catafilos. Culmos floríferos 50-60 cm de alto, con 1-2 nudos en la zona de entrenudos alargados, láminas mayormente basales. Vainas con la porción distal igual de ancha o ligeramente más ancha que la lámina, glabras, pajizas, lustrosas, membranáceas. Aurículas 0,5-1 mm de largo, lóbulos obtusos, conspicuas, pilosas, el margen membranáceodenticulado y ciliolado. Pulvínulo de la vaina presente, piloso. Lígulas 0,5-1,5 mm de largo, ápice truncado, margen membranácea-denticulado y ciliada. Láminas $20-30 \mathrm{~cm} \times 2-2,5 \mathrm{~mm}$, conduplicadas, no rígidas, erectas a decumbentes, ápice atenuado, pungente; superficie abaxial escabrosa; superficie adaxial glabrescente. Panículas 12-15 cm de largo, lineares, contraídas; ramas adpresas al raquis, esparcidamente escabrosas. Espiguillas 5,5-6 mm de largo, con 2(-3) antecios, pajizas; raquilla corta, escabrosa y glabra. Glumas iguales, escabrosas, con el nervio medio conspicuo; gluma inferior $4,5-5 \mathrm{~mm}$ de largo, más larga que los $2 / 3$ o igual que el antecio adyacente, ápice agudo, 1-nervia; gluma superior 4-5 mm de largo, más larga que los $2 / 3$ o igual que el antecio adyacente, ápice agudo, 3-nervia. Lemas del antecio basal 4,5-5 $\mathrm{mm}$ de largo, escabrosa, ápice acuminado. Páleas con quillas esparcidamente escabrosas. Lodículas 0,6-1 $\mathrm{mm}$ de largo, lobadas, margen entera, glabras. Anteras 1-2 mm de largo. Ápice del ovario glabro. 
Distribución y hábitat. Esta especie se conoce solamente de la colección tipo, en las estepas de la región biogeográfica Altoandina.

Observaciones. Especie próxima a $F$. fiebrigii, pero ésta última se diferencia por presentar espiguillas de 9-11(-12) mm de largo, con 6-7 antecios y las glumas subiguales, con la gluma inferior de $3-3,8(-4) \mathrm{mm}$ de largo.

Notas nomenclaturales. St.-Yves (1927: 292) menciona dos ejemplares tipo en la descripción de F. parodii: "herb. Par. et herb. St-Y.". El espécimen de G no fue localizado pero se halló otro duplicado en LIL. Se selecciona el espécimen BAA 00000175 como lectotipo.

29. Festuca purpurascens Banks \& Sol. ex Hook. f., Fl. Antarct. 2: 383, t. 140. 1847. LECTOTIPO: CHILE. XII Región: Provincia Tierra del Fuego, "Strait of Magalhaens: Port Famine", 1833, Capt. King 539 (lectotipo K 00433655 imagen! designado por Matthei (1982: 24) corregido de "typus"; isolectotipo BAA 2066!). Figura 28.

Festuca purpurascens var. submutica É. Desv., Fl. Chil. 6: 429. 1854. LECTOTIPO: CHILE. XII Región: Provincia Tierra del Fuego, sin localidad, 1769, J. Banks \& D. Solander s.n. (lectotipo BM 001043705 imagen! designado por Ospina et al. (2015: 43); isolectotipos GH 00023764 imagen!, NY 00381093 imagen!, S (SR2295) imagen!, S S054935 imagen!, US 1232980 imagen!, US 1232979 imagen!).

Festuca purpurascens var. aristata É. Desv., Fl. Chil. 6: 429. 1854. TIPO: CHILE. X Región: Provincia Chiloé, "San Carlos, sobre peñascos a la orilla del mar", sin fecha, C. Gay s.n. (probable holotipo P).

Festuca insularis Steud., Syn. Pl. Glumac. 1: 312. 1854 [1855]. [non F. insularis Popov, Bot. Mater. Gerb. Inst. Bot. Akad. Nauk Kazahsk. SSR 18: 4. 1957]. LECTOTIPO: CHILE. XIV Región: Provincia Valdivia, “Ins. Valenzuela prope Valdiviam”, diciembre 1850, W. Lechler 276 (lectotipo (de primer paso) P designado por Matthei (1982: 24) corregido de "typus", lectotipo (segundo-paso) P 00625325 imagen! designado por Ospina et al. (2015: 43); isolectotipos P 00625326 imagen!, B 2589 imagen!, B 2590 imagen!, BAA 2045!, K 433660 imagen!, LE 737 imagen!, LE 738 imagen!, S SR2276 imagen!, US 0091406 imagen!, W 32662 imagen!).

Festuca lechleriana Steud., Syn. P1. Glumac. 1: 428. 1854 [1855]. LECTOTIPO: CHILE. XII Región: Provincia Tierra del Fuego, "Magallanes, Sandy Point", sin fecha, W. Lechler $1224 a$ (lectotipo (de primer paso) P designado por Matthei (1982: 24) corregido de 
“typus”, lectotipo (de segundo paso) P 00625318 imagen! designado por Ospina et al. (2015: 43); isolectotipo P 00625320 imagen!, P 00625319 imagen!, B AA2051!, FR 31332 imagen!, LE 741 imagen!, US 91398 imagen!).

Festuca platyphylla Steud., Syn. P1. Glumac. 1: 428. 1854 [1855]. Festuca purpurascens var. platyphylla (Steud.) Saint-Yves (1927: 271). LECTOTIPO: CHILE. XII Región: Provincia Tierra del Fuego, "Magallanes, Sandy Point", sin fecha, W. Lechler 1224 (lectotipo (de primer paso) P designado por Matthei (1982: 24) corregido de "typus", lectotipo (de segundo paso) P 00625321 imagen! designado por Ospina et al. (2015: 43); isolectotipos P 00625324 imagen!, P 00625323 imagen!, P 00625322 imagen!, BAA 2131!, BAA 2130!, BR 6862879 imagen!, FR 31334 imagen!, K 433656 imagen!, LE 742 imagen!, LE 743 imagen!, S SR2293 imagen!, US 81574 imagen!).

Festuca laxiflora Phil., Linnaea 29(1): 98. 1858, nom. illeg. hom., non F. laxiflora A. Rich., 1850. TIPO: CHILE. XI Región: Provincia Aysen, "Loco S. Rafael dicto Peninsulae Tres Montes", sin fecha, F. Fonk 54 (holotipo SGO 63812!; isotipo BAA 2049!).

Festuca dumetorum Phil., Linnaea 33(3-4): 297. 1864. nom. illeg.hom., non F. dumetorum L., 1762. Festuca trachylepis Hack. ex Druce, Bot. Exch. Club Brit. Isles Rep. 4: 30.1915. Festuca philippii Bech., Candollea 7: 520. 1938, nom. superfl. LECTOTIPO: CHILE. XIV Región: Provincia Valdivia, “in praedio meo San Juan crescit”, diciembre1860, $F$. Philippi s.n. (lectotipo (de primer paso) SGO designado por Matthei (1982: 26) corregido de "typus", lectotipo (de segundo paso) SGO 37436! designado Ospina et al. (2015: 44); isolectotipos SGO 63825!, BAA 2029!, BAA 2028! K 433661 imagen!).

Festuca davilae Phil., Anales Univ. Chile 94: 176. 1896. LECTOTIPO: CHILE. Región Metropolitana: Provincia Santiago de Chile, "in subandinis provincia Santiago loco dicto salto de Conchalí", noviembre 1875, F. Philippi s.n. (lectotipo (de primer paso) SGO designado por Matthei (1982: 26) corregido de "typus", lectotipo (de segundo paso) SGO 63810! designado Ospina et al. (2015: 44); isolectotipos SGO 37438!, W 19160039756 imagen!).

Festuca glaucophylla Phil., Anales Univ. Chile 94: 178. 1896. LECTOTIPO: CHILE. X Región: Provincia Palena, “in valle fluminis Palena a born”, enero-febrero 1887, F. Delfin s.n. (lectotipo SGO 63826! designado por Matthei (1982: 26) corregido de “typus"; isolectotipo BAA 2042!, W 19160039754 imagen!).

Festuca serranoi Phil., Anales Univ. Chile 94: 178. 1896. LECTOTIPO: CHILE. X Región: Provincia Palena, “in valle fluminis Palena a born”, 1887, F. Delfin s.n. (lectotipo SGO 
063824! designado por Matthei (1982: 26) corregido de "typus"; isolectotipo W 1916 0039753 imagen!).

Festuca purpurascens fo. aristata St.-Yves, Candollea 3: 268. 1927. LECTOTIPO: CHILE. XIV Región: Provincia Valdivia, “in insula Valenzuela”, diciembre 1850, Lechler 276 (lectotipo G desigado Ospina et al. (2015: 43); isolectotipo W 0032662 imagen!).

Festuca purpurascens fo. scabriuscula St.-Yves, Candollea 3: 268. 1927. TIPO: CHILE. XIV Región: Provincia de Valdivia, sin localidad, sin fecha, Philippi s.n. (holotipo B).

Plantas rizomatosas, con catafilos. Culmos floríferos 35-70 cm de alto, con 1-2 nudos en la zona de entrenudos alargados, láminas a lo largo de los culmos. Vainas con la porción distal no más ancha que la lámina, pilosas, pajizas, lustrosas, membranáceas. Aurículas ausentes. Pulvínulo de la vaina ausente. Lígulas 1-2 mm de largo, ápice obtuso, margen membranáceodentado y fimbriado. Láminas $16-30(-35) \mathrm{cm} \times 4-6 \mathrm{~mm}$, planas, a convolutas, no rígidas, erectas, ápice agudo, no pungente; superficie abaxial glabra; superficie adaxial pobremente escabrosa y cortamente pilosa. Panículas 9-17 cm de largo, lanceoladas, laxas; ramas ascendentes a patentes, escabrosas. Espiguillas (9-)10-15 mm de largo, con 3-7 antecios, violáceas; raquilla escabrosa. Glumas subiguales, esparcidamente escabrosas, con el nervio medio conspicuo; gluma inferior 2-3,5 mm de largo, más larga que el 1/2 del antecio adyacente, ápice agudo, 1-nevia; gluma superior 5-7 mm de largo, igual o más corta que los $2 / 3$ del antecio adyacente, ápice obtuso, 3-nevia. Lemas del antecio basal 5-8 mm de largo (sin arista), distalmente escabrosas, ápice aristado, arista $0,5-1,5 \mathrm{~mm}$ de largo. Páleas con quillas escabrosas. Lodículas 0,5-1 mm de largo, lobadas, margen entero, glabras. Anteras 3-4,5 mm de largo. Ápice del ovario piloso.

Distribución y hábitat. Esta especie se distribuye desde $35^{\circ}$ hasta $52^{\circ} \mathrm{S}$, entre $0-500 \mathrm{~m}$ de altitud. Crecen en suelos arenosos en Chile (desde la IX a la XII Región y un registro en la Región Metropolitana) y en Argentina (Río Negro hasta Tierra del Fuego). Es un componente común de la estepa graminosa en las provincias biogeográfica Altoandina (en el sur), Patagónica y Subantártica.

Observaciones. Se distingue por su hábito rizomatoso, sus hojas planas sin aurículas, las lígulas obtusas con margen membranáceo-dentado y fimbriado, las láminas con la superficie adaxial cortamente pilosa. Se observaron especímenes con proliferación vegetativa: sin colector (SI 15242, SI 10995), Soriano 3449 (BAA). Número cromosómico $2 \mathrm{n}=42$ (Dubcovsky \& Martínez 1992). 
Notas nomenclaturales. Desvaux (1854: 429) citó tres sintipos para $F$. purpurascens var. submutica: "Chile: Tierra del Fuego, 1769, Bancos y Solander sn", "Chile: Puerto del Hambre, Hombron s.n .” y "Chile. Prov. Valdivia, este sitios Herbosos en Los Llanos, C. Gay s.n.”. El único espécimen en BM (Banks >\& Solander s.n., BM 001043 705) es designado como lectotipo de Festuca purpurascens var. submutica porque es una planta completa y hay duplicados en otras instituciones.

En el protólogo de Festuca purpurascens fo. aristata, St.-Yves (1927: 268, 310) menciona numerosos sintipos: "Chile: Lechler 276" (G, W), "Salzmann s.n." (G), "Philippi s.n.” (B), "Philippi 687" (G), "Buchtien s.n." (G), “Argentina: Parodi 3180" (BAA; G) y "Illin s.n." (BAA, G).

30. Festuca pyrogea Speg., Anales Mus. Nac. Buenos Aires 5: 97. 1896. Festuca ovina var. pyrogea (Speg.) Hack., Wiss. Erb. Schwed. Sudpolar-Exp. 4(4): 7. 1906. TIPO: ARGENTINA. Tierra del Fuego, Antártida e Islas del Atlántico Sur: Departamento Ushuaia, "in scopulosis prope Ushuáia”, 1882, C. L. Spegazzini s.n. (probable material original LP 001493!). Figura 29.

Festuca ovina subvar. pubispicula St.-Yves, Candollea 3: 163. 1927. LECTOTIPO: ARGENTINA. Santa Cruz: departamento Güer Aike, "Patagonie: Gouv. De Santa Cruz, bords du Río Coyle", sin fecha, L. Dauber 179 (lectotipo G 00099484 imagen! designado por Ospina et al. (2015: 46); isolectotipo BAA).

Festuca pyrogea var. elata Parodi, Revista Argent. Agron. 20: 197. 1953. TIPO: ARGENTINA. Río Negro: Departamento Bariloche, "Bariloche”, 3 febrero 1934, L. R. Parodi 11643 (probable material original BAA).

Plantas cespitosas, sin catafilos. Culmos floríferos 10-28 cm de alto, con 1-2 nudos en la zona de entrenudos alargados, láminas mayormente basales. Vainas con la porción distal más ancha que la lámina, esparcidamente pilosas, pajizas, lustrosas, membranáceas. Aurículas $0,5-0,8 \mathrm{~mm}$ de largo, inconspicuas, escabrosas, margen membranáceo-ciliado. Pulvínulo de la vaina presente, piloso. Lígulas $0,5-1 \mathrm{~mm}$ de largo, ápice truncado, margen membranáceo-piloso. Láminas 2,5-6 cm $\times 0,5-1 \mathrm{~mm}$, no rígidas, curvadas a patentes, ápice agudo; superficie abaxial glabra; superficie adaxial pilosa. Panículas 2,5-6 cm de largo, lineares, contraídas, usualmente reducidas a racimos (pedicelos de las espiguillas sobre el raquis). Espiguillas 4-8 $\mathrm{mm}$ de largo, con 3-4 antecios, verdosas y con tintes violáceos; raquilla escabrosa. Glumas desiguales, distalmente escabrosas, con el nervio medio conspicuo; gluma inferior 2-4 mm de largo, más 
corta que el 1/2 del antecio adyacente, ápice agudo, 1-nevia; gluma superior 3,5-5 mm de largo, igual o más larga que los $2 / 3$ del antecio adyacente, ápice obtuso, 3-nevias. Lemas del antecio basal 4,5-6,5 mm de largo (sin arista), densamente escabrosas y pilosas, ápice aristado, arista 1-1,5 mm de largo. Páleas con quillas escabrosas. Lodículas $0,4-0,8 \mathrm{~mm}$ de largo, lobadas, margen entero, glabras. Anteras 0,8-1,2 mm de largo. Ápice del ovario piloso.

Distribución y hábitat. Esta especie se distribuye desde $38^{\circ}$ hasta $52^{\circ} \mathrm{S}$, entre $100-1100 \mathrm{~m}$ de altitud. Crecen en suelos arenosos y cerca de cuerpos de agua o lagunas, en Chile (XII Región) y en Argentina (Neuquén hasta Tierra del Fuego). Es un componente significativo de las estepas graminosas en las provincias biogeográficas Altoandina (en el sur), Subantártica y Patagónica.

Observaciones. Se distingue por su bajo porte, creciendo al ras del suelo, las laminas no rígidas de 2,5-6 cm de largo, panículas usualmente reducidas a racimos y lemas densamente escabrosas y pilosas con aristas de 1-1,5 mm de largo. Es comúnmente confundida con $F$. magellanica (ver observaciones de este taxón).

Notas nomenclaturales. El espécimen LP 001493 no tiene etiqueta pero su morfología se corresponde a la descripción original de $F$. ovina var. pyrogea.

Saint-Yves (1927: 163) menciona dos especímenes de la colección original de $F$. ovina subvar. pubispicula: "Herb. Par. et herb. St-Y"; selecciono el ejemplar G 00099484 como lectotipo. El duplicado en BAA no fue localizado.

El ejemplar L. R. Parodi 11643 de Festuca pyrogea var. elata no fue hallado en BAA.

31. Festuca rigescens (J. Presl) Kunth, Enum. Pl. 1: 403. 1833. Diplachne rigescens J. Presl, Reliq. Haenk. 1(4-5): 260. 1830. LECTOTIPO: PERÚ. Huanuco: "habitat in montanis Peruviae huanoccensibus", 1871, T. Haenke 69 (lectotipo PR designado por Renvoize (1998: 111) corregido de "holotipo"; isolectotipos B 100250185 imagen!, MO 2114172 imagen!, MO 2968424 imagen!, US 865884 imagen!). Figura 30.

Diplachne brevifolia J. Presl, Reliq. Haenk. 1(4-5): 261. 1830. Festuca haenkei Kunth., Enum. Pl. 1: 403. 1833., non F. brevifolia Muhl. 1817. LECTOTIPO: PERÚ. Huánuco: "habitat in montanis Peruviae huanoccensibus", T. Haenke s.n. (lectotipo B 100250186 imagen! designado Ospina et al. (2015: 49); isolectotipo PR imagen!, HAL 106998 imagen!, MO 2114159 imagen!, US 2875386 imagen!). 
Festuca humilior Nees \& Meyen, Gramineae: 35. 1841. Festuca haenkei var. humilior (Nees \& Meyen) St.-Yves, Candollea 3: 206. 1927. LECTOTIPO: PERÚ. Sin departamento: “in alti cordillerae Peruvianae", abril 1831, F. J. F. Meyen s.n. (lectotipo B 10186537 imagen! aquí designado; isolectotipos B 10186536_b imagen!, BAA!, CAS 98809 imagen!, US 91407imagen!). syn. nov.

Festuca deserticola Phil., Fl. Atacam. 56. 1860. LECTOTIPO: CHILE. III Región. "Desertorum Atacama, ad aquam Varas dictam, $24^{\circ} 38$ lat., 9700 p.s. m”, R. A. Philippi s.n. (lectotipo SGO 063829! designado por Ospina et al. (2013b: 165); isolectotipos B 100002624 imagen!, SGO 037446!, US 1939378 (fragm. ex SGO 037446 \& foto)!, W 0031927 imagen!).

Festuca paupera Phil., Verz. Antofagasta Pfl. 89. 1891. Festuca deserticola var. paupera (Phil.) St.-Yves, Candollea 3: 211. 1927. LECTOTIPO: CHILE. I Región: Provincia Tarapacá, "Ad Calalaste reperta", 3700 m, F. Philippi s.n. (lectotipo SGO 063813! designado por Ospina et al. (2013b: 165); isolectotipos SGO 037426!, US 556547 (fragm. ex “SGO-PHIL-298”)!, W 0039731 imagen!).

Festuca saltana St.-Yves, Candollea 3: 305, f. 96. 1927. LECTOTIPO: ARGENTINA. Salta: sin departamento, "Puna de Atacama", febrero 1900, E. L. Holmberg s.n. (lectotipo G 00099483 imagen! designado por Ospina et al. (2015: 49); isolectotipo BAA herb. Parodi 1882, LP!).

Festuca petersonii Renvoize, Gram. Bolivia 122, f. 21B, 27C-D. 1998. TIPO: BOLIVIA. Potosí: Provincia Nor Lípez, "14 mi S de San Vicente y 43 mi N of San Pablo de Lípez”, 4200 m, 18 marzo 1993, P. M. Peterson, S. Lagaard \& R. Soreng 12974 (holotipo LPB 0000281!; isotipos K 000433591 imagen!, US 3277025 imagen!).

Plantas densamente cespitosas, sin catafilos. Culmos floríferos $12-18(-25) \mathrm{cm}$ de alto, con 1 nudo en el área distal de la zona de entrenudos alargados, láminas mayormente basales. Vainas con la porción distal más ancha que la lámina, glabras, pajizas a pardas, lustrosas, membranáceas. Aurículas 1-1,5 mm de largo, lóbulos obtusos, conspicuas, glabras, margen entero. Pulvínulo de la vaina presente, glabro. Lígulas $0,5-1 \mathrm{~mm}$ de largo, ápice truncado, margen entero. Láminas $8-10(-12) \mathrm{cm} \times 0,7-1(-1,3) \mathrm{mm}$, conduplicadas, usualmente no rígidas, erectas a flexuosas o recurvadas, ápice obtuso, no pungente; superficie abaxial glabra; superficie adaxial esparcidamente escabrosa y cortamente pilosa. Panículas (3-)4-6(-7) cm de largo, lineares, contraídas; ramas adpresas al raquis, esparcidamente escabrosas. Espiguillas (8)9-11 mm de largo, con 4-6 antecios, verdosas a pajizas; raquilla esparcidamente escabrosa. Glumas subiguales, distalmente escabrosa, nervio medio conspicuo; gluma inferior (2,5-)3-4 
$\mathrm{mm}$ de largo, más corta que el 1/2 del antecio adyacente, ápice agudo, 1-nevia; gluma superior 4,5-5,5 mm de largo, más corta que los $2 / 3$ del antecio adyacente, ápice obtuso, 3-nevia. Lemas del antecio basal 5-6(-6,5) $\mathrm{mm}$ de largo (sin arista), notoriamente falcada, esparcidamente escabrosa, ápice acuminado a cortamente aristado, arista 0,5-1 $\mathrm{mm}$ de largo. Páleas con quillas escabrosas. Lodículas $0,3-0,6 \mathrm{~mm}$ de largo, lobadas, glabras. Anteras 2,5-3,5 mm de largo. Ápice del ovario glabro.

Distribución y hábitat. Esta especie se distribuye desde $16^{\circ}$ hasta $30^{\circ} \mathrm{S}$, entre $2500-4800 \mathrm{~m}$ de altitud. Crece en suelos rocosos, laderas de altas montañas, cerca de los cuerpos de agua, en Chile (desde la II a la XV Región) y en Argentina (de Salta hasta La Rioja). Además, se distribuye en Bolivia (La Paz, Potosí y Tarija) y Perú (Arequipa, Cerro de Pasco, Junín y Tacna) de acuerdo com Türpe (1969), Tovar (1972), Renvoize (1998) y Catalán \& Müller (2012). Es un componente florístico característico y con abundancia significativa en las estepas graminosas de las provincias biogeográficas Altoandina, Puna y del Desierto.

Nueva cita: Festuca rigescens fue descripta para los andes del Perú. Durante el desarrollo del presente trabajo se encontraron ejemplares recolectado en Chile cuyas características morfológicas se corresponden con las de F. rigescens y ésta constituye la primera cita para ese país.

Observaciones. Se distingue de todas las especies de Festuca por los culmos floríferos con un solo nudo en el área distal de la zona de entrenudos largos, por sus láminas no rígidas y erectas a flexuosas y con ápice obtuso, y las lemas son falcadas.

Notas nomenclaturales. Selecciono el ejemplar depositado en B [B 10 0250186] como lectotipo de Diplachne brevifolia porque es el más completo y se encuentra bien conservado. Además, el ejemplar depositado en PR no fue localizado. Como J. Presl consultó todo el material de Haenke, todos los duplicados se considera como sintipos vistos por el autor.

De acuerdo con los caracteres observados en el material tipo, donde se observa un solo nudo en el área distal de la zona de entrenudos alargados y por las características mencionadas en el protólogo, Festuca humilior (considerada como especie aceptada para la flora de Argentina por Catalán \& Müller (2012) y para la flora de Bolivia por Renvoize (1998)), se propone como sinónimo nuevo de F. rigescens. Se hallaron varios duplicados de la colección de Meyen de Pisacoma, Perú, por lo tanto se seleccionó un lectotipo para $F$. humilior. 
Las características descriptas para $F$. deserticola y los ejemplares tipo analizados se corresponden con la morfología de $F$. rigescens y, además, presenta los caracteres diagnósticos de ésta ultima especie, por lo tanto se consideran coespecíficas. El ejemplar "SGO-PHIL-289", publicado como holotipo de Festuca deserticola (Darbyshire et al., 2003; Catalán \& Müller, 2012) no fue hallado en SGO. Tampoco se encontraron los ejemplares SGO 063830 y SGO 63827, que han sido citados como isotipos de $F$. deserticola y también de $F$. chrysophylla (Catalán \& Müller 2012). Se selecciona como lectotipo de Festuca deserticola al ejemplar SGO 063829 por su buen estado y por presentar las características mencionadas en el protólogo.

Catalán \& Müller (2012) consideraron a $F$. paupera como sinónimo de $F$. chrysophylla. Sin embargo, el material tipo del primer taxón presenta láminas tiernas, flexuosas, con la superficie adaxial cortamente pubescente, panículas de $6,8 \mathrm{~cm}$ de largo y antecios esparcidamente escabrosos hacia el ápice; mientras que $F$. chrysophylla presenta láminas conduplicadas, rígidas, erectas a divergentes, con la superficie adaxial largamente pubescente (con pelos sobresaliendo por el margen), las panículas de (6-)10-20 cm y los antecios pubescentes en el margen. Por lo tnato, consideramos que $F$. paupera es sinónimo de $F$. rigescens, ya que las características del material tipo coinciden con el patrón morfológico de $F$. rigescens. El ejemplar "SGO-PHIL298”, publicado como holotipo de F. paupera (Darbyshire et al. 2003; Catalán \& Müller 2012), no fue hallado en SGO. Se selecciona como lectotipo el ejemplar SGO 063813 porque se encuentra completo y los caracteres morfológicos descriptos en el protólogo se corresponden con el ejemplar.

Saint-Yves (1927: 305-307) menciona dos ejemplares en el protólogo de Festuca saltana: "herb. Parodi 1882 et herb. St-Y ". El ejemplar G [G 00099483] fue designado como lectotipo para $F$. saltana ya que es un ejemplar completo, los caracteres coinciden con el protólogo y se encuentra bien conservado. Festuca saltana ha sido citado como sinónimo de $F$. chrysophylla (Darbyshire et al. 2003; Catalán \& Müller 2012) pero el estudio del material tipo de ese taxón permite subordinarlo a $F$. rigescens.

Festuca petersonii fue descripta por Renvoize para Bolivia. La característica más sobresaliente de la descripción original de F. petersonii es la panícula formada por 2-3 espiguillas, mientras que los restantes caracteres no difieren de la morfología de F. rigescens. El análisis de numerosos materiales de herbario de $F$. rigescens permitió observar una variación continua en el número de espiguillas en las panículas. Así, los ejemplares Escobar X-235 (SI), Kalin et al. 2661 (CONC) y Werdermann 1127 (SI) presentan 2-3(4) espiguillas; los ejemplares Infantes 2314 (BAA), Marticorena et al. 134, 194 (CONC), Parodi 10085 (BAA) y Peterson et al. 17763 (SI) presentan 3-5(6); y los ejemplares Hunziker \& Caso 4119 (BAA), Infantes 2450 (LIL) y Krapovickas et al. 5673 (BAA) presentan panículas conformadas por más de 6 
espiguillas. Sobre la base de lo expuesto se considera que $F$. petersonii es sinónimo de $F$. rigescens.

32. Festuca roigii Dubcovs. \& Rúgolo, Bol. Soc. Argent. Bot. 26(3-4): 236. 1990. TIPO: ARGENTINA. Mendoza: Departamento Las Heras, "Cordón de los Pajaritos (Salto de la Cabra)", 27 noviembre 1979, F. A. Roig 9774 (holotipo, MERL-52014 (dos pliegos)!; isotipo SI 61814!). Figura 31.

Plantas cespitosas, sin catafilos. Culmos floríferos 25-50(-90) cm de alto, con 2-3 nudos en la zona de entrenudos alargados, láminas mayormente basales. Vainas con la porción distal más ancha que la lámina, esparcidamente pilosas, pajizas, lustrosas, membranáceas. Aurículas 0,30,6 mm de largo, conspicuas, glabras, margen membranáceo-ciliado. Pulvínulo de la vaina ausente. Lígulas 0,2-0,5 $\mathrm{mm}$ de largo, ápice truncado, margen membranáceo-ciliado. Láminas 5-10 $\mathrm{cm} \times 0,4-1 \mathrm{~mm}$, conduplicadas, no rígidas, circinadas, ápice agudo; superficie abaxial escabrosa; superficie adaxial pilosa. Panículas $4-15 \mathrm{~cm}$ de largo, lineares, contraídas; usualmente reducidas a racimos (pedicelos de las espiguillas sobre el raquis). Espiguillas 8-14 mm de largo, con 3-6 antecios, verdosas y con tintes violáceos; raquilla escabrosa. Glumas subiguales, distalmente escabrosa, con el nervio medio conspicuo; gluma inferior 2-4 mm de largo, más larga que el 1/2 del antecio adyacente, ápice agudo, 1-nevia; gluma superior 3,5-5 $\mathrm{mm}$ de largo, más corta que los $2 / 3$ del antecio adyacente, ápice obtuso, 3-nevia. Lemas del antecio basal 5,45-7,2 $\mathrm{mm}$ de largo, densamente escabrosas y pilosas, ápice mucronado, mucrón de 0,3-0,5 mm de largo. Páleas con quillas escabrosas. Lodículas $0,4-0,8 \mathrm{~mm}$ de largo, lobadas, margen entero, glabras. Anteras 0,8-1,2 mm de largo. Ápice del ovario glabro.

Distribución y hábitat. Esta especie se distribuye desde $33^{\circ}$ hasta $34^{\circ} \mathrm{S}$, entre $1500-2800 \mathrm{~m}$ de altitud. Crece en laderas de las altas montañas en la cordillera de los Andes y en campos con presencia de nieve temporal, en Argentina (Mendoza). Es un componente florístico escaso de las estepas graminosas en la provincia biogeográfica Altoandina (en el sur).

Observaciones. Esta especie se reconoce fácilmente entre las especies de Festuca en el Cono Sur por sus láminas circinadas de 0,4-1 mm de diámetro, no rígidas y con el ápice agudo y por sus cañas floríferas con 2-3 nudos en la zona de entrenudos alargados. Número cromosómico $2 \mathrm{n}=28$ (Dubcovsky \& Rúgolo de Agrasar 1990). 
33. Festuca rubra L., Sp. Pl. 1: 74. 1753 (1 mayo 1753). Festuca ovina var. rubra (L.) Sm., Engl. Fl. 1: 139. 1824. LECTOTIPO: SWEDEN. Sin estado: "In paludosis prati regii Upsalia", no collector s.n. (lectotipo GB designado por Jarvis et al. (1987: 301)). Figura 32.

Festuca rubra var. simpliciuscula Hack., Ark. Bot. 7(2): 10, f. 2. 1907. Festuca simpliciuscula (Hack.) E. B. Alexeev, Bot. Žhurn. (Moscow \& Leningrad) 69: 351. 1984. TIPO: ARGENTINA. Santa Cruz: Lago San Martín, río Fósiles, in uliginosis, 1 abril 1905, P.K.H Dusén 5925 (holotipo S S05-4966 imagen!; isotipos BAA, K000433675 imagen!, SI 001834!). syn. nov.

Plantas rizomatosas, con catafilos. Culmos floríferos $35-80 \mathrm{~cm}$ de alto, con 1 nudo en la zona de entrenudos alargados, láminas a lo largo de los culmos. Vainas con la porción distal no más ancha que la lámina, escabrosas y distalmente pilosas, verdosas a rojizas, no lustrosas, membranáceas y fibrosas. Aurículas ausentes. Pulvínulo de la vaina presente, esparcidamente piloso. Lígulas 1-1,5 $\mathrm{mm}$ de largo, ápice truncado, margen membranáceo-ciliado. Láminas 10-35 cm $\times 1-1,8 \mathrm{~mm}$, conduplicadas, no rígidas, erectas, ápice agudo; superficie abaxial escabrosa y esparcidamente pilosa; superficie adaxial esparcidamente escabrosa y cortamente pilosa. Panículas $8-20 \mathrm{~cm}$ de largo, lanceoladas, laxas; ramas ascendentes a patentes, escabrosas, glabras. Espiguillas (8-)9-12 mm de largo, con 2-5 antecios, verdosas a rojizas; raquilla esparcidamente escabrosa y glabra. Glumas subiguales, esparcidamente escabrosas en el ápice y la base, con el nervio medio conspicuo; gluma inferior 2,5-3,5 $\mathrm{mm}$ de largo, más larga que el 1/2 del antecio adyacente, ápice agudo, 1-nevia; gluma superior 4,5-5,5 mm de largo, igual o más corta que los $2 / 3$ del antecio adyacente, ápice obtuso, 3-nevia. Lemas del antecio basal 5-7 $\mathrm{mm}$ de largo (sin arista), distalmente escabrosas, ápice aristado, arista 0,51,5 mm de largo. Páleas con quillas escabrosas. Lodículas 0,5-1 mm de largo, lobadas, margen entero, glabras. Anteras 3-4,5 mm de largo. Ápice del ovario glabro.

Distribución y hábitat. Especie introducida. Se distribuye en zonas templado-frías de Europa, Asia y América del Norte. Se ha introducido en América del Sur y en otros lugares con el fin de generar un mejor forraje para el pastoreo. En Nueva Zelanda está naturalizada en las praderas y matorrales, a 0-1800 m (Edgar \& Cono 2000). En Chile, Festuca rubra se ha coleccionado en la Cordillera de Santiago (Matthei 1982) y se estudiaron muestras de la Región IV, V y XII. En Argentina, se estudiaron ejemplares de Mendoza, Neuquén y Santa Cruz provenientes de localidades situadas en las provincias biogeográficas Patagónica y Subantártica. 
Observaciones. Se distingue de otras especies por su hábito rizomatoso, las láminas planas e inflorescencias rojas. Este taxón se interpreta como un complejo poliploide y muestra diversas morfologías y los límites específicos no son claros (Darbyshire et al. 2003). Además, la hibridación y/o introgresión, cultivares y ecotipos oscurecen los límites taxonómicos.

El único taxón subespecífico de $F$. rubra mencionado de América del Sur es $F$. rubra subsp. corcovadensis St-Yves, pero este taxón es sinónimo de F. magellanica. Número cromosómico 2n = 42, 49, 63 (Jauhar 1975; Ghorai \& Sharma 1981; Bailey \& Stace 1992).

Notas nomenclaturales. Festuca rubra var. simpliciuscula fue descrito por Hackel (1907) y reconocido como una variedad de F. rubra por Türpe (1969) y Nicora (1978). Sin embargo, Alexeev (1984) la propone como una especie (F. simpliciuscula); Catalán \& Müller (2012) la tratan con categoría de especie en la flora Argentina, por el ovario con ápice piloso y la lígula de longitud mayor a $1 \mathrm{~mm}$. El primer carácter no se observó en el isotipo de SI examinado y las lígulas mayores de $1 \mathrm{~mm}$ entran dentro de la variabilidad morfológica de F. rubra; por lo tanto se considera aquí a Festuca rubra var. simpliciuscula como sinónimo de F. rubra.

34. Festuca subantarctica Parodi, Revista Argent. Agron. 20: 225. 1953. Festuca commersonii Franch., Miss. Sci. Cape Horn, Bot. 5: 388, t. 8. f. C \& (b-e). 1889. nom. illeg. hom., non Festuca commersonii Spreng., 1825[1824]. LECTOTIPO: ARGENTINA o CHILE. “Détroit du Magellans", P. Commerson s. n. (lectotipo F designado por Matthei (1982: 57) corregido de "typus"; isolectotipos P 00625306!, US 2875392a imagen!, fragm. \& foto ex P). Figura 33.

Plantas cespitosas, sin catafilos. Culmos floríferos 30-65 cm de alto, con 1-2 nudos en la zona de entrenudos alargados, láminas basales. Vainas con la porción distal más ancha que la lámina, glabras, pajizas, membranáceas. Aurículas $0,7-1 \mathrm{~mm}$ de largo, lóbulos obtusos, inconspicuas, glabras, margen membranáceo-ciliado. Pulvínulo de la vaina presente, glabro. Lígulas $0,5-1$ mm de largo, ápice truncado, margen membranáceo-ciliado. Láminas (6-)10-20 cm × 0,7-1 $\mathrm{mm}$, conduplicadas, no rígidas, erectas o curvadas, ápice agudo; superficie abaxial y adaxial lisas, glabras. Panículas 8-12 cm de largo, lanceolada, laxas; ramas adpresas al raquis, pobremente escabrosas. Espiguillas 7-12 mm de largo, con 4-5 antecios, pardas a verdosas; raquilla esparcidamente escabrosas, algunas veces con antecios proliferados. Glumas subiguales, escabrosas en la porción distal, con el nervio medio conspicuo; gluma inferior 5-6 $\mathrm{mm}$ de largo, más larga que el 1/2 del antecio adyacente, 1-nevia; gluma superior 5,5-7 mm de largo, más corta que los $2 / 3$ del antecio adyacente, 3-nevia. Lemas del antecio basal 5-6,5 mm de largo (sin arista), o 16-20 mm en espiguillas proliferadas, escabrosas en el dorso y ápice, 
ápice aristado, arista 0,5-1 $\mathrm{mm}$ de largo. Páleas con quillas ciliadas. Lodículas $0,8-1,3 \mathrm{~mm}$ de largo, lobadas, margen eroso, glabras. Anteras 3-4 mm de largo. Ápice del ovario glabro.

Distribución y hábitat. Esta especie se distribuye desde $48^{\circ}$ hasta $53^{\circ} \mathrm{S}$, entre $0-175 \mathrm{~m}$ de altitud. Crecen exclusivamente en bancos de arena y costas marinas, en Chile (XII Región) y en Argentina (Tierra del Fuego). Es un componente escaso en las estepas graminosas de las provincias biogeográficas Patagónica y Subantártica.

Observaciones. Esta especie se distingue entre las especies de Festuca del Cono Sur por presenta sus láminas glabras en ambas superficies.

Notas nomenclaturales. Matthei (1982) citó a $F$. subantártica como sinónimo de $F$. thermarum (= F. acanthophylla var. acanthophylla, en este trabajo). Luego de examinar el material tipo (isolectotipos) en el que se observan las láminas glabras en ambas superficies y las espiguillas proliferando, como así también por su distribución geográfica restringida, consideramos a $F$. subantártica como una especie aceptada.

35. Festuca superba Parodi ex Türpe, Darwiniana 15: 201. 1969. TIPO: ARGENTINA. Jujuy: Departamento Capital [Dr. Manuel Belgrano]: “Termas de Reyes”, 2000 m, 5 febrero 1943, L. R. Parodi 14552 (holotipo BAA [2 pliegos: BAA 00002132 y BAA00002133]!; isotipo US 1865220!). Figura 34.

Plantas rizomatosas, con catafilos. Culmos floríferos 170-195(-200) cm de alto, con 3 nudos en la zona de entrenudos alargados, láminas a lo largo de los culmos. Vainas con la porción distal no más ancha que la lámina, escabrosas, pajizas, no lustrosas, cartáceas. Aurículas ausentes. Pulvínulo de la vaina presente, glabro. Lígulas 3,5-5 $\mathrm{mm}$ de largo, ápice truncado, margen membranáceo-dentado y fimbriado. Láminas 45-65 cm $\times 10-15(-17) \mathrm{mm}$, planas, a convolutas, no rígidas, erectas, ápice agudo; superficie abaxial escabrosa; superficie adaxial pilosa. Panículas 40-45 cm de largo, ovadas, laxas; ramas erectas y flexuosas, esparcidamente escabrosas. Espiguillas 13-18 mm de largo, con 5-7 antecios imbricados, pajizas; raquilla esparcidamente escabrosa. Glumas subiguales, glabras y escariosas, con los nervios conspicuos; gluma inferior 7-8,5 mm de largo, más larga que el 1/2 del antecio adyacente, ápice agudo, 3-5nevia; gluma superior 8-9 mm de largo, igual o más larga que los $2 / 3$ del antecio adyacente, ápice agudo, 3-5-nevias. Lemas (9-)10-11 mm de largo, escabrosas, ápice agudo. Páleas con 
quillas pilosas. Lodículas $2-2,5 \mathrm{~mm}$ de largo, lobadas, margen fimbriado, fimbrias de 3-4,5 $\mathrm{mm}$ de largo. Anteras 2,5-3 mm de largo. Ápice del ovario piloso.

Distribución y hábitat. Esta especie se distribuye desde $23^{\circ}$ hasta $26^{\circ} \mathrm{S}$, entre $2000-2500 \mathrm{~m}$ de altitud. Crece cerca de cuerpos de agua o en los bosques de aliso en Argentina, restringida en Jujuy.

Observaciones. Esta especie se caracteriza por sus láminas planas hasta de 10-15(-17) mm de ancho, sus vainas son escabrosas y cartáceas, lígulas 3,5-5 $\mathrm{mm}$ de largo con el ápice truncado, margen membranáceo-dentado y fimbriado, además por sus panículas de 40-45 cm de largo, ovadas y laxas. Número cromosómico 2n = 56 (Dubcovsky \& Martínez 1992).

36. Festuca ulochaeta Nees ex Steud., Syn. Pl. Glumac. 1: 305. 1854. LECTOTIPO: BRASIL. Estado desconocido: sin localidad, sin fecha, F. Sellow s.n. (lectotipo B 100002609 imagen! aquí designado; isolectotipo B 100002608 imagen!, K 000433578 ex B imagen!). Figura 35.

Festuca leptothrix Trin. ex Döll, F. Bras. 2(3): 115. 1878. TIPO: BRASIL. São Paulo: sin localidad, G. H. von Langsdorff s. $n$. (holotipo, LE (LE-TRIN-2818.01), isotipo US 91399 (fragm.)).

Plantas rizomatosas, catafilos presentes. Culmos $(45-) 55-100(-120) \mathrm{cm}$ de alto, con $2-8$ nudos en la caña florífera, láminas a lo largo de los culmos. Vainas con la porción distal no más ancha que la lámina, esparcidamente escabrosas, pajizas pardas, papiráceas a membranáceas, fibrosas. Aurículas ausentes. Pulvínulo de la vaina ausente. Lígulas $(0,2-) 0,5-3,5 \mathrm{~mm}$ de largo, ápice truncado a ligeramente obtuso, margen membranáceo-ciliado. Láminas (8-)15-30 $\mathrm{cm} \times(2-) 3-7(-8) \mathrm{mm}$, planas, a convolutas, ápice agudo a acuminado, no pungente; superficie abaxial escasamente escabrosa; superficie adaxial escabrosa y pilosa. Panículas $15-45 \mathrm{~cm}$ de largo, ovadas-lanceoladas, laxas; ramas erectas a patentes y flexuosas, escabrosas y con escasos pelos esparcidos. Espiguillas 7-10 $\mathrm{mm}$ de largo, 2-3 floras, verdosas; raquilla escabrosa y glabra. Glumas desiguales, escabrosas en el ápice, con los nervios conspicuos; gluma inferior $(1,2-) 1,5-4,5 \mathrm{~mm}$ de largo, más larga que el 1/3 del antecio adyacente, 1 nervia; gluma superior (2,5-)3-6 mm de largo, más corta que $\operatorname{los} 2 / 3$ del antecio adyacente, 3-nervia. Lemas del antecio basal 5-8(-9) $\mathrm{mm}$ de largo ( $\sin$ arista), escabrosa, ápice atenuado y aristado, arista apical 5-12 
$\mathrm{mm}$ de largo, erecta a flexuosa, escabrosas. Páleas con quillas escabrosas. Lodículas $0,5-1 \mathrm{~mm}$ de largo, lobadas, margen eroso, glabras. Anteras 1-3 mm de largo. Ápice del vario piloso.

Distribución y hábitat. Esta especie se distribuye desde $20^{\circ}$ hasta $30^{\circ} \mathrm{S}$, entre $0-1000 \mathrm{~m}$ de altitud. Crece en márgenes de arroyos y caminos de selvas en Argentina (Misiones, Jujuy, Salta, Tucumán) y en Brasil (Paraná, Río Grande do Sul, Santa Catarina, São Paulo), en las provincias biogeográficas de las Yungas y Paranense. Además se distribuye en Colombia y Venezuela (Catalán \& Müller 2012).

Observaciones. Se diferencia fácilmente entre las especie de Festuca del Cono sur por sus láminas de $(8-) 15-30 \mathrm{~cm} \times(2-) 3-7(-8) \mathrm{mm}$, planas y enrolladas en seco, ápice agudo a acuminado, no pungente, las espiguillas de 7-10 $\mathrm{mm}$ de largo, sus lemas con ápice atenuado y aristado, arista apical 5-12 $\mathrm{mm}$ de largo, erecta a flexuosa y escabrosas. Número cromosómico $2 n=42$ (Dubcovsky \& Martínez 1992), 2n = 28 (Smarda 2006).

Notas nomenclaturales. Se hallaron tres sintipos de F. Sellow s.n. de Brasil, dos de ellos en B y un ejemplar en K ex B. No se hallaron isotipos en P. Se selecciona como lectotipo el ejemplar B 100002609 que se encuentra mejor preservado.

37. Festuca uninodis Hack., Anales Mus. Nac. Buenos Aires 13: 524. 1906. LECTOTIPO: ARGENTINA. Tucumán: Departamento Tafí del Valle: "Cerro Muñoz, región de la Puna”, 4150 m, 29 enero 1903, M. Lillo 3025b [Herb. T. Stuckert 15,372] (lectotipo W 19160004765 imagen! aquí designado; isolectotipos CORD 00001663!, LIL 000597!, LIL 000598!, LIL 000596!, US 00642130 ex W imagen!). Figura 36.

Festuca uninodis fo. binodis Hack. ex St.-Yves, Candollea 3: 234. 1927. TIPO: ARGENTINA. Tucumán: Departamento Tafí, "El infiernillo", M. Lillo 5660 [Herb. T. Stuckert 17795] (holotipo CORD).

Festuca stuckertii St.-Yves, Candollea 3: 304. 1927. TIPO: ARGENTINA. Tucumán: Departamento Tafí, Río Blanco, Barrancas, 2600 m s.m., 26 diciembre 1908. M. Lillo 8873 (holotipo G00099480 imagen!, isotipos BAA 00000178 Col. Typus 1338!, CORD 00001661 !, LIL 44100!). syn. nov.

Plantas densamente cespitosas, sin catafilos. Culmos floríferos (20-)30-45 cm de alto, con 1-2 nudos en la zona de entrenudos alargados, láminas mayormente basales. Vainas con la porción 
distal igual o ligeramente más ancha que la lámina, escabrosas, pajizas a verdosas, no lustrosas, papipiráceas. Aurículas 1-1,5 mm de largo, lóbulos obtusos, conspicuas, escabrosas, margen membranáceo-dentado y ciliado. Pulvínulo de la vaina ausente. Lígulas $0,8-1,2 \mathrm{~mm}$ de largo, ápice truncado, escabrosas, margen membranáceo-dentado y ciliado. Láminas $10-25 \mathrm{~cm} \times 0,5-$ $1 \mathrm{~mm}$, conduplicadas, rígidas, erectas, ápice pungente a rostrado; superficie abaxial escabrosa; superficie adaxial escabrosa y cortamente pilosa. Panículas $8-10 \mathrm{~cm}$ de largo, lineares, contraídas; ramas adpresas al raquis, escabrosas. Espiguillas $8-10 \mathrm{~mm}$, con 3-4 antecios, verdosas; raquilla escabrosa. Glumas subiguales, escabrosas en el dorso, con el nervio medio conspicuo; gluma inferior 3-3,5 mm de largo, igual o más larga que el 1/2 del antecio adyacente, ápice acuminado, 1-nevia; gluma superior 4-4,5 mm de largo, más corta que $10 \mathrm{~s}^{2} / 3$ del antecio adyacente, ápice agudo, 3-nevia. Lemas del antecio basal 6-7(-7,5) $\mathrm{mm}$ de largo (sin arista), escabrosas sobre los nervios y en la porción distal, ápice largamente acuminado a aristado, arista 0,5-1 mm de largo (caduca). Páleas con quillas ciliadas. Lodículas $0,5-1 \mathrm{~mm}$ de largo, lobadas, margen entero, glabras. Anteras 2-2,5 mm de largo. Ovario ápice glabro.

Distribución y hábitat. Esta especie se distribuye desde $23^{\circ}$ hasta $26^{\circ} \mathrm{S}$, entre $3600-4500 \mathrm{~m}$ de altitud. Crece cerca en laderas rocosas de las montañas de los Andes en Argentina (Jujuy hasta Catamarca). Es un componente florístico escaso en las estepas andinas de las provincias Puneña y Altoandina con distribución geográfica restringida.

Observaciones. Esta especie es similar $F$. hypsophila, pero se diferencia por el menor porte de la planta, por sus láminas con la superficie abaxial escabrosa, y sus espiguillas de 8-10 $\mathrm{mm}$ de largo. Se observó poco material de este taxón.

Notas nomenclaturales. Existen varios duplicados de la colección original Lillo $3025 b$ de $F$. uninodis. Se selecciona el lectotipo de $\mathrm{W}$ porque está en buen estado; y porque considero que todos los materiales fueron vistos por el autor de la especie, ya que llevan su determinación (como indica Stuckert 1906).

El ejemplar de G es el único de los duplicados que lleva la indicación "Festuca stuckertii sp nova" con letra de Saint Yves, por eso se considera holotipo. No se hallaron caracteres en el material tipo que permitan separar a F. stuckertii de F. uninodis. Considero que tanto Festuca uninodis fo. binodis como Festuca stuckertii fueron descriptas sobre la base de ejemplares que solo se diferencian de F. uninodis por presentar dos nudos en las cañas; en algunas especies este es un caracter variable. 
38. Festuca ventanicola Speg., Contr. Fl. Sierra Vent.: 72. 1896. TIPO: ARGENTINA. Buenos Aires: Partido Tornquist, "crece en las cumbres más altas y entre los peñascos mas pelados y secos", noviembre 1895, C. L. Spegazzini s.n. [12540] (holotipo LP, dos cartulinas 001497! y LP 001498!; isotipos BAA 00000180!). Figura 37.

Plantas cespitosas, sin catafilos. Culmos $30-40(-45) \mathrm{cm}$ de alto, con $2-3$ nudos en la caña florífera, láminas mayormente basales. Vainas con la porción distal no más ancha o igual de ancha que la lámina, esparcidamente escabrosas, pajizas a pardas, papiráceas a membranáceas, fibrosas. Aurículas 0,8-1,2 mm de largo, lóbulos obtusos, conspicuas, margen membranáceofimbriado y cortamente ciliado. Pulvínulo de la vaina ausente. Lígulas 1-1,8 mm de largo, ápice truncado a emarginado, esparcidamente escabrosas, margen membranáceo-fimbriado y cortamente piloso. Láminas (8-)10-18 cm × 1-2 mm, coduplicadas, ápice agudo a acuminado, no pungente; superficie abaxial lisa, glabra; superficie adaxial escabrosa, esparcidamente pilosa. Panículas 10-15 cm de largo, oblongas-lanceoladas, laxas; ramas erectas a patentes y flexuosas, escabrosas y escasos pelos esparcidos. Espiguillas (8-)10-15 mm de largo, 4-6 floras, verdosas; raquilla escabrosa. Glumas desiguales, escabrosas en el ápice, glabras, con los nervios conspicuos; gluma inferior (4-)4,5-5,5 mm de largo, más larga que el 1/3 del antecio adyacente, 1 nervia; gluma superior (7,5-)8-9 mm de largo, igual o más corta que los $2 / 3$ del antecio adyacente, 3-nervia. Lemas del antecio basal (8,5-)9-11 $\mathrm{mm}$ de largo (sin arista), esparcidamente escabrosas, ápice atenuado y aristado, arista apical 5-10(-14) $\mathrm{mm}$ de largo, erecta a flexuosa, escabrosas. Páleas con quillas escabrosas. Lodículas $0,5-1 \mathrm{~mm}$ de largo, lobadas, margen eroso, glabras. Anteras 2,5-3,5 mm de largo. Ápice del vario con pelos.

Distribución y hábitat. Esta especies de distribuye desde $37^{\circ}$ hasta $39^{\circ}$, entre $500-1000 \mathrm{~m}$ de altitud. Crece entre grietas y fisuras de roquedales de esquistos en las sierras pampeana de la provincia de Buenos Aires (de La Ventana y de Cura Malal), en la provincia biogeográfica Pampeana.

Observaciones. Se diferencia fácilmente entre las epecies de Festuca del Cono Sur por presentar aurículas conspicuas, de 0,8-1,2 $\mathrm{mm}$ de largo, vaina sin pulvínulo, lígulas de 1-1,8 $\mathrm{mm}$ de largo, con el margen fimbriado-ciliado, las espiguillas (8-)10-15 mm de largo, 4-6 floras, verdosas; por la lemas con ápice atenuado y aristado y la arista de 5-10(-14) mm de largo. Número cromosómico 2n = 42 (Dubcovsky \& Martínez 1988, 1991).

Notas nomenclaturales. El holotipo de $F$. ventanicola está montado en dos cartulinas relacionadas con un mismo número de herbario de Spegazzini 12590. El duplicado de BAA es un fragmento. 
39. Festuca weberbaueri Pilg., Bot. Jahrb. Syst.37: 512. 1906. TIPO: PERÚ. Puno: "Dep. Puno, ad Azangaro in calcareis", 4000 m, febrero 1902, Weberbauer 473 (holotipo B 10 0002636 imagen!; isotipos BAA 00000865 (fragm. ex B) imagen!, S S05-5090 (fragm. ex B) imagen!, US 00132518 (fragm. ex B) imagen!). Figura 38.

Festuca weberbaueri var. foliosa Pilg., Bot. Jahrb. Syst. 37: 513. 1906. TIPO: PERÚ. Puno: “in collibus ad Cuzco, in formationeaperta, sed hic illic dewnse graminibus, fruticulis et Bromeliaceis armatis obtecta", 3500-3600 m, mayo 1905, Weberbauer 4872 (holotipo B 100250133 imagen!; isotipos, S S05-5093 (fragm. ex B) imagen!, US 00132519 (fragm. ex B) imagen!).

Plantas cespitosas, sin catafilos. Culmos floríferos 30-55 cm de alto, con 2-4 nudos en la zona de entrenudos alargados, láminas mayormente basales. Vainas con la porción distal igual o no más ancha o igual de ancha que la lámina, esparcidamente escabrosas, pajizas, no lustrosas, cartáceas. Aurículas 1-1,3 mm de largo, lóbulos obtusos, conspicuas, esparcidamente escabrosas, margen membranáceo-ciliada. Pulvínulo de la vaina presente, esparcidamente piloso. Lígulas 0,3-0,7 $\mathrm{mm}$ de largo, ápice truncado, margen eroso. Láminas (8-)10-20 cm $\times$ 2-4 mm, conduplicadas, no rígidas, erectas a curvadas, ápice subulado, no pungente; superficie abaxial esparcidamente escabrosa; superficie adaxial escabrosa, pilosa. Panículas 6-10(-12) cm de largo, lineares, contraídas; ramas adpresas al raquis, escabrosas y glabras. Espiguillas 8-9,5 $\mathrm{mm}$ de largo, con 2-3(-4) antecios, verdosas; raquilla escabrosa, glabra. Glumas iguales, escabrosas, con el nervio medio conspicuo; gluma inferior $4,3-5(-5,3) \mathrm{mm}$ de largo, igual o más larga que los $2 / 3$ del antecio adyacente, ápice agudo, 1-nervia; gluma superior 4,5-5,5 mm de largo, más larga que los $2 / 3$ del antecio adyacente, ápice agudo, 3-nervia. Lemas del antecio basal 5,5-6,5 (sin arista) $\mathrm{mm}$ de largo, escabrosas hacia el ápice y el dorso, ápice aristado, arista 0,3-0,5 mm de largo. Páleas con quillas ciliadas. Lodículas $0,8-1 \mathrm{~mm}$ de largo, lobadas, margen eroso, glabras. Anteras 2,8-3,3 mm de largo. Ápice del ovario glabro.

Distribución y hábitat. Distribución y hábitat. Esta especie se distribuye desde $17^{\circ}$ hasta $28^{\circ}$ S, entre 2800-4200 m de altitud. Crece sobre las laderas rocosas de las montañas de la cordillera de los Andes en Argentina (Salta y Tucumán). Además, se distribuye en Perú (Arequipa, Cerro de Pasco, Huánuco, Junín y Tacna, Tovar 1972). Este taxón no fue citado por Renvoize (1998) para la flora de Bolivia. Es característica de las estepas en la provincia biogeográfica Altoandina. 
Observaciones. Esta especie se reconoce fácilmente entre las especies del Cono Sur, por presentar láminas no rígidas, con la superficie abaxial esparcidamente escabrosa y el ápice tubulado, las espiguillas de $8-9(-9,5) \mathrm{mm}$ de largo, con $2-3(-4)$ antecios y con glumas de igual longitud.

Notas nomenclaturales. El ejemplar tipo de B de Festuca weberbaueri es el único con etiqueta original y los duplicados son fragmentos del anterior, por lo tanto se considera el holotipo. Lo mismo ocurre con el holotipo de Festuca weberbaueri var. foliosa.

40. Festuca werdermannii St.-Yves, Candollea 3: 301. 1927. LECTOTIPO: CHILE. IV Región: Provincia Elqui, “Coquimbo: Baños del Toro”, ca. 3600 m, diciembre 1923, E. Werdermann 209 (lectotipo G 0099477 imagen! designado por Aleexev (1984: 349); isolectotipos B 100250132 imagen!, MO 1288151 imagen!, S, SI 001838!, US 1498126 imagen!). Figura 39.

Plantas densamente cespitosas, sin catafilos. Culmos floríferos $20-35(-40) \mathrm{cm}$ de alto, sin nudos en la zona de entrenudos alargados, láminas mayormente basales. Vainas con la porción distal más ancha que la lámina, cortamente pilosa distalmente, pajizas, lustrosas, membranáceas. Aurículas 1-2 mm de largo, lóbulos obtusos, escabrosas, margen eroso y cortamente ciliado. Pulvínulo de la vaina presente, cortamente piloso a glabro. Lígulas $2-3,5 \mathrm{~mm}$ de largo, ápice obtuso, margen eroso y cortamente ciliado. Láminas 6-10 $\mathrm{cm} \times 0,9-1,1 \mathrm{~mm}$, rígidas, erectas a recurvadas, ápice rostrado; superficie abaxial escabrosa y pobremente pilosa; superficie adaxial escabrosa y cortamente pilosa. Panículas 4-12 cm de largo, lineares, contraídas; ramas adpresas al raquis, escabrosas. Espiguillas 6-10 mm de largo, con 3-5 antecios; raquilla escabrosa y glabra. Glumas subiguales, escabrosas distalmente, con el nervio medio no conspicuo; gluma inferior 2,5-3 mm de largo, más larga que el 1/2 del antecio adyacente, ápice agudo, 1-nevia; gluma superior 4-5 mm de largo, más corta que $10{ }^{2 / 3}$ del antecio adyacente, ápice obtuso, 3nevia. Lemas del antecio basal 4,5-6 $\mathrm{mm}$ de largo, escabrosas, ápice obtuso. Páleas con quillas glabras. Lodículas $0,5-0,6 \mathrm{~mm}$ de largo, lobadas, margen eroso, glabras. Anteras 2,73,5 mm de largo. Ápice del ovario piloso.

Distribución y hábitat. Esta especie se distribuye desde $27^{\circ}$ hasta $32^{\circ} \mathrm{S}$, entre $2800-4200 \mathrm{~m}$ de altitud. Crece en suelos arenosos y cerca a los cuerpos de agua de la cordillera de los Andes en Chile (desde la III a laIV Región) y en Argentina (La Rioja y San Juan), en las provincias biogeográficas Altoandina y del Desierto. 
Nueva cita. Esta especie era conocida solo para Chile, no se había registrado su presencia para la flora de Argentina. Durante el desarrollo del presente trabajo se encontraron ejemplares recolectados en Argentina cuyas características se corresponden a esta especie y ésta constituye la primera cita para el país.

Observaciones. Se distingue de todas las demás especies de Festuca del Cono Sur por presentar páleas con quillas glabras, lemas con el ápice obtuso, las láminas escabrosas abaxialmente y lígulas de 2-3,5 mm de largo, con el ápice obtuso.

41. Festuca yalaensis Joch. Müll. \& Catalán, Darwiniana 48: 88. 2010. TIPO: ARGENTINA. Jujuy: departamento Doctor Manuel Belgrano, "Lagunas de Yala, small valley W of Laguna Rodeo", $24^{\circ} 6^{\prime} \mathrm{S}, 65^{\circ} 29^{\prime} \mathrm{W}$, ca. $2200 \mathrm{~m}, 24$ noviembre 2008, J. Müller \& $P$. Catalán 10522 (holotipo JE; isotipos LPB, M, MCNS, RB, SI 96835!, SI 126080!, W). Figura 40.

Plantas rizomatosas, estoloniferas, catafilos presentes. Culmos floríferos $50-120 \mathrm{~cm}$ de alto, con (3-)4-5 nudos en la zona de entrenudos alargados, láminas a lo largo de los culmos. Vainas con la porción distal no más ancha que las láminas, escabrosas, pardas a grisáceas al envejecer, no lustrosas, cartáceas. Aurículas 0,3-0,5 mm de largo, lóbulos truncados, escabrosas, glabras, margen eroso-fimbriado. Pulvínulo de la vaina presente, esparcidamente piloso. Lígulas 0,30,5 mm de largo, ápice truncado, margen eroso-fimbriado. Láminas 15-40 cm $\times 0,8-2(-3) \mathrm{mm}$, no rígidas, decumbentes, conduplicadas, a veces algo expandidas, ápice agudo, no pungente; superficie abaxial escabrosa; superficie adaxial escabrosa en el margen y esparcidamente pilosa. Panículas 8-17 cm de largo, lanceoladas, laxas; ramas erectas a raramente adpresas al raquis, escabrosas. Espiguillas (5-)6-9-(-11,5) $\mathrm{mm}$ de largo, con $(2-) 3-5(-7)$ antecios, verdosas a violáceas; raquilla escabrosa. Glumas desiguales, escabrosas con el nervio medio no conspicuo; gluma inferior (1,8-)2,8-3,8 mm de largo, igual o más larga que el 1/2 del antecio adyacente, ápice acuminado, 1-nervia; gluma superior (3-)3,8-4,8 mm de largo, más larga que los $2 / 3$ del antecio adyacente, ápice agudo, 3-nervia. Lemas del antecio basal 4,5-6,3 $\mathrm{mm}$ de largo (sin arista), escabrosas hacia el ápice y el dorso, ápice acuminado a cortamente aristado, arista 0,8 $\mathrm{mm}$ de largo. Páleas con quillas ciliadas. Lodículas 1-1,5 $\mathrm{mm}$ de largo, lobadas, margen entera, glabras. Anteras 2-3 mm de largo. Ápice del ovario piloso. 
Distribución y hábitat. Se ha coleccionado una sola vez en Argentina, en Jujuy, a 2200 metros de altitud. Crece en laderas herbáceas húmedas, en ambientes nemorales (Catalán \& Müller 2012).

Observaciones. Esta especie se reconoce fácilmente entre las especies del Cono Sur, por su crecimiento rizomatoso-estolonífero, las láminas planas y el ovario piloso.

\section{Especies de Festuca excluidas del Cono Sur}

1. Festuca dolichophylla J. Presl, Reliq. Haenk. 1(4-5): 258. 1830. TIPO: PERÚ. Sin departamento: "In montis Peruviae". Perú, T. Haenke s.n. (holotipo PR; isotipos LE TRIN 2799.01, US2875401 (fragmento ex PR) imagen!).

Diplachne scirpifolia J. Presl, Reliq. Haenk. 1(4-5): 261. 1830. Festuca scirpifolia (J. Presl) Kunth, Enum. P1. 1: 403. 1833. TIPO: PERÚ. Sin departamento: “In montanis Peruviae huanoccensibus. Perú", T. Haenke s.n. (holotipo, PR).

Esta especie crece en Perú (Tovar 1972), Bolivia (Renvoize 1998), Ecuador y Centro América. Fue citada para la flora de Argentina por Catalán \& Müller (2012), sin embargo, no se ha estudiado material de la Argentina perteneciente a esta especie. Los especímenes argentinos citados por estos autores corresponde a $F$. hypsophila, distinguiéndose por presentar las vainas lustrosas, membranosas y con el pulvínulo conspicuo, las láminas con el ápice pungente a rostrado y las lemas con ápice largamente acuminado a aristado (vs. vainas no lustrosas, cartáceas, pulvínulo de la vaina ausente, láminas flexuosas de ápice subulado y no pungente, lemas con el ápice subulado y no aristado, en F. dolichopohylla).

2. Festuca buchtienii Hack., Repert. Spec. Nov. Regni Veg. 6: 160. 1909. Festuca scirpifolia subsp. buchtienii (Hack.) St.-Yves, Candollea 3: 227. 1927. TIPO: BOLIVIA. La Paz: sin provincia, "Bergabhänge", 3700 m, 25 marzo 1907, O. Buchtien 870 (holotipo W 19160004684 imagen!; isotipos LIL 000058!, US 00513394 (fragmento ex W) imagen!).

Esta especie fue descripta para Bolivia por Hackel (1909) y citada por Renvoize (1998). Fue reconocida como sinónimo de F. humilior por Darbyshire et al. (2003) y Zuloaga et al. (2008). Fue citada para la flora Argentina (Jujuy y Salta) por Türpe (1969) y Catalán \& Müller (2012). Sin embargo, el estudio detallado de las colecciones citadas en estos últimos trabajos, permitió 
detectar que se trata de ejemplares de $F$. rigescens. No se ha estudiado material proveniente de la Argentina que permitan confirmar la presencia de este taxón. Festuca buchtienii es morfológicamente similar a $F$. rigescens, distinguiéndose de estas por presentar laminas escabrosas en la superficie abaxial y cañas floríferas sin nudos visibles (vs. láminas con superficie abaxial glabra, cañas con 1 nudo en el área distal de la zona de entrenudos alargados, en F. rigescens).

3. Festuca juncifolia St.-Amans, Flora Agenaise 40, t. 5. 1821. TIPO: FRANCIA. Frances, Dans les Landes (material tipo no visto).

Esta especie fue citada para Argentina (Nicora 1978; Zuloaga et al. 2008) y para Chile (Matthei 1982). Durante el desarrollo de la presente investigación no se encontraron muestras de Chile o Argentina con las características de F. juncifolia. Se trata de una especie europea que se excluye de la flora del Cono Sur.

4. Festuca tectoria St.-Yves, Candollea 3: 240. 1927. TIPO: PERÚ. Ayacucho:. Provincia de Coracora, Weberbauer Gl. Per. N 5811 (holotipo, B).

Esta especie fue descrita por Yves (1927) para Perú y Bolivia. Matthei (1982: 45) citó esta especie para la flora de Chile como primer hallazgo en ese territorio, en base a los especímenes Ricardi et al. 163, 165 y 188 (CONC), todos de Arica. Los especímenes no fueron localizados en CONC. De acuerdo con la descripción dada por Matthei (1982), plantas cespitosas con aurículas de margen ciliado que crece en el norte de Chile, estos especímenes podrían pertenecer a F. hypsophila.

\section{Especies de Festuca dudosas del Cono Sur}

1. Festuca magensiana Potztal, Wildenowia 2(2): 166. 1959. TIPO: CHILE. XII Región: Provincia Magallanes, Chabunco, ca. 35 km. Von Punta Arenas. Fundo Los Robles. Weg nach Norden, 16.3 1956, Sillard s.n. (holotipo B, isotipos CONC, HIP).

Esta especie fue descripta para la flora del sur de Chile sobre la base la colección Sillard s.n. depositada en el herbario B. Este taxón solo se conoce de su material tipo, el cual no fue localizado en B y no fueron encontrados los isotipos en CONC ni HIP. Incluso, se detectó que 
las colecciones Magens $3350 \mathrm{~A}$ y Magens 3350 depositados en $\mathrm{B}$, ambos provenientes de la misma colección, ha sido erróneamente vinculados con el material tipo -nomenclatural de $F$. magensiana. Además, en las colecciones de los herbarios visitados, no se hallaron ejemplares coleccionados actualmente; esto, coincide con Mattehi (1982) quien menciona "especie muy afin a $F$. magellanica, de la cual podría ser solo una variedad. Solo futuras colecciones podrán demostrar esta sospecha", inclusive, este autor no considera ni propone cambios taxonómicos con respecto a este taxón. Por lo anterior, se considera que $F$. magensiana es una especie dudosa para la flora de Chile. 


\section{ILUSTRACIONES}
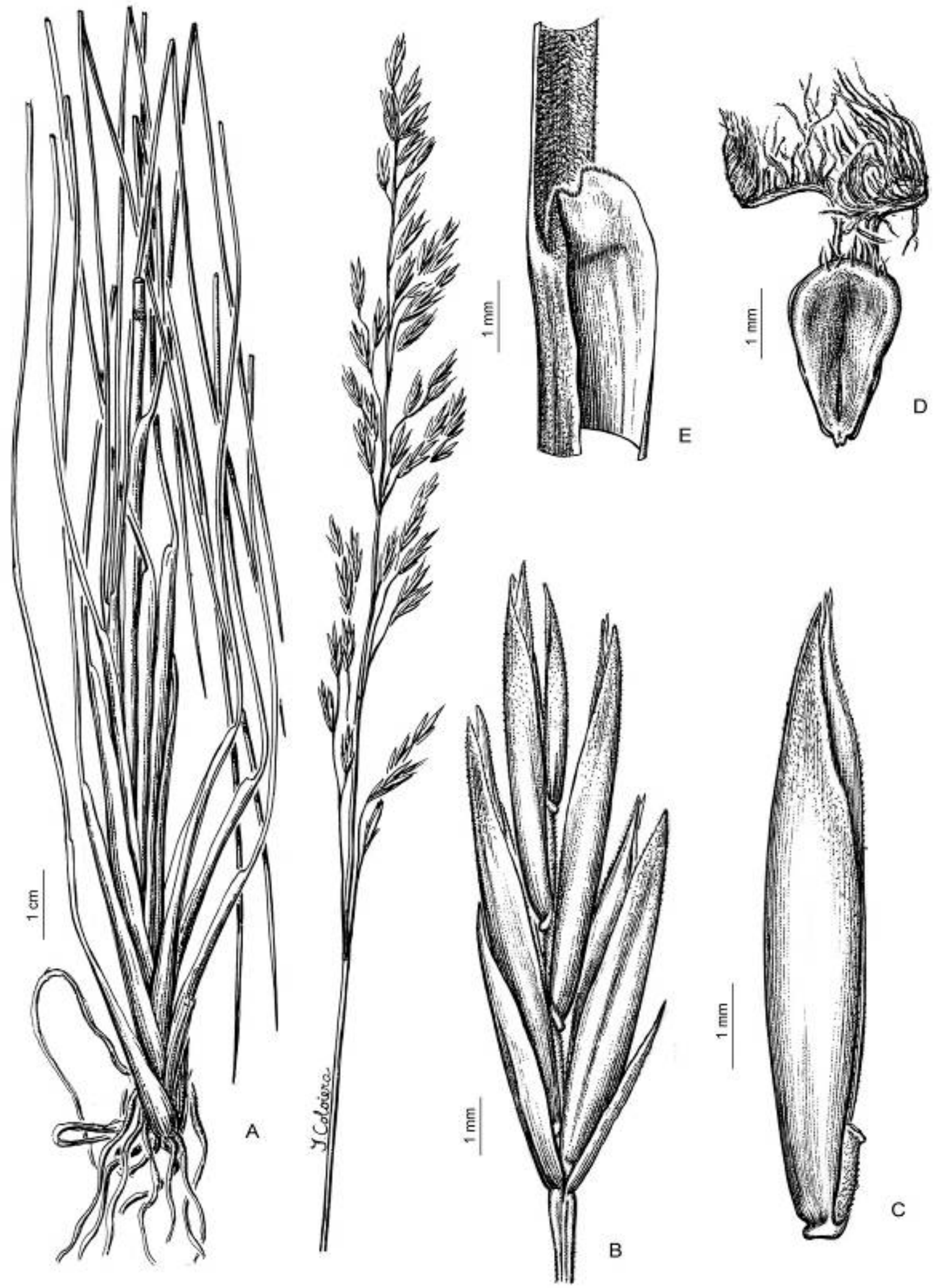

FIGURA 1. Festuca acanthophylla var. acanthophylla. A. Hábito e inflorescencia. B. Espiguilla. C. Antecio, vista lateral. D. Ovario. E. Zona ligular. Reproducido de Nicora (1978: 117, fig. 69). 

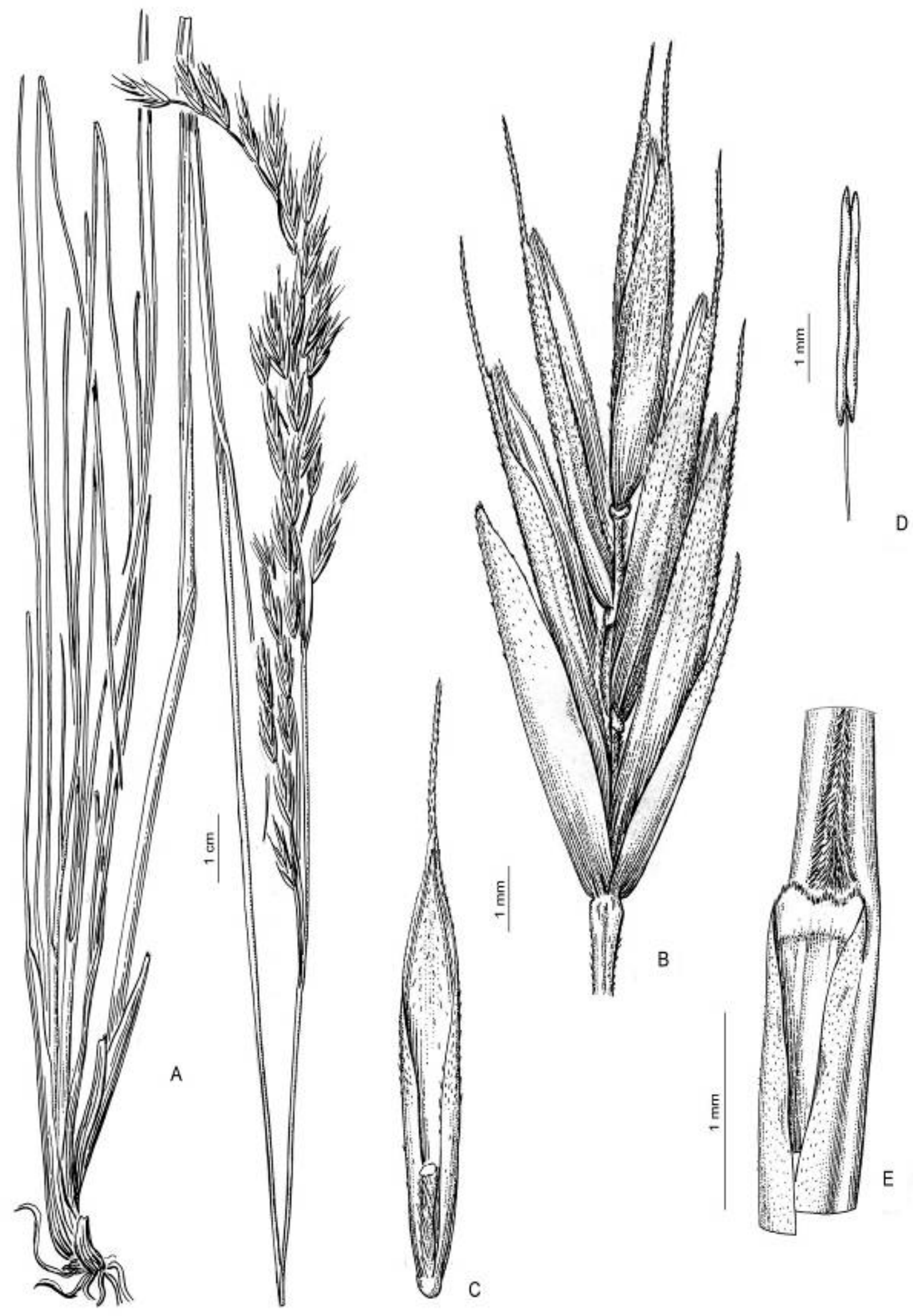

FIGURA 2. Festuca acathophylla var. scabriuscula. A. Hábito e inflorescencia. B. Espiguilla. C. Antecio, vista ventral. D. Antera. E. Zona ligular. Reproducido de Nicora (1978: 111, fig. 66). 


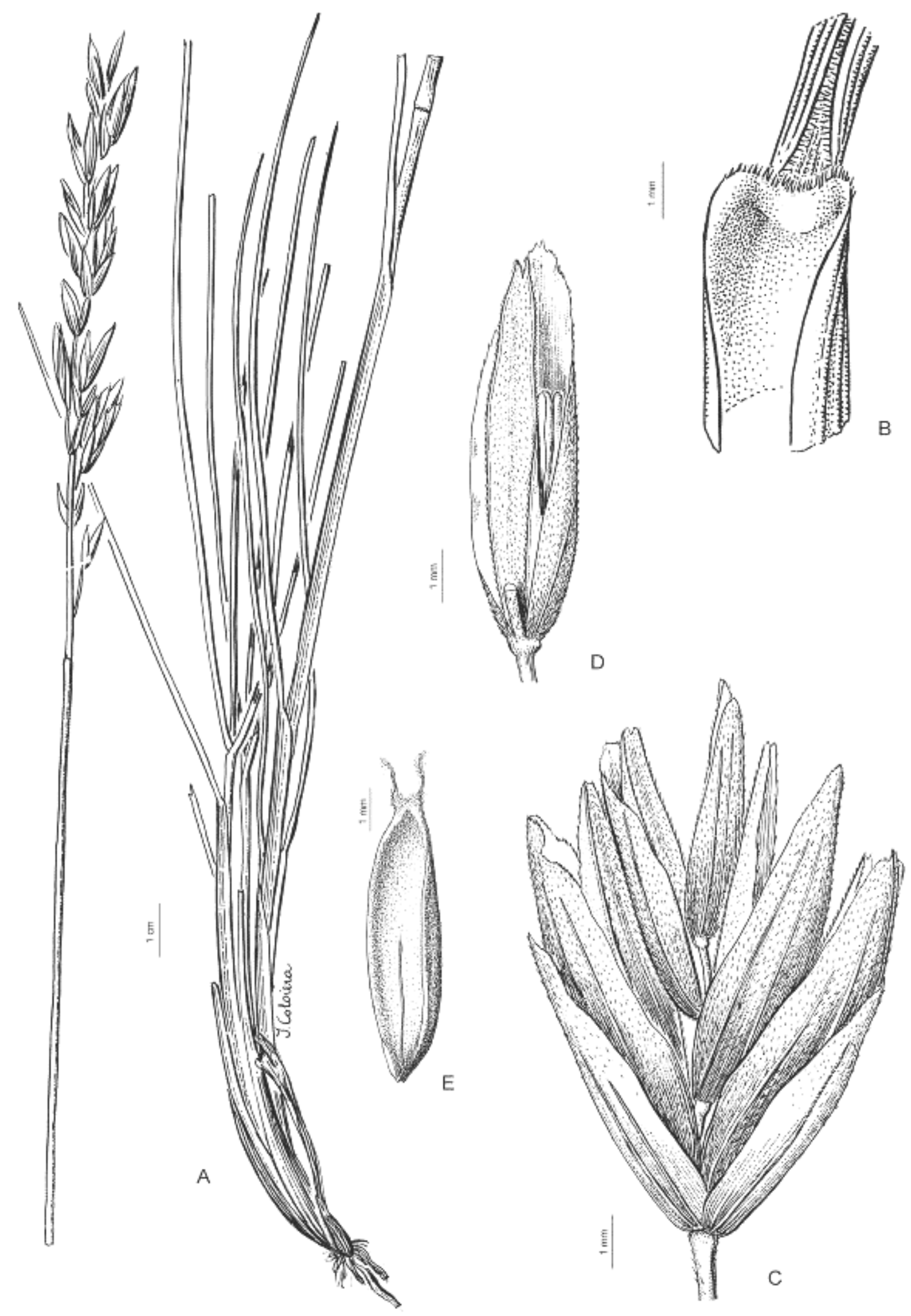

FIGURA 3. Festuca argentina. A. Hábito e inflorescencia. B. Zona ligular. C. Espiguilla. D. Antecio, vista ventral. E. Ovario. Reproducido de Nicora (1978: 117, fig. 70). 

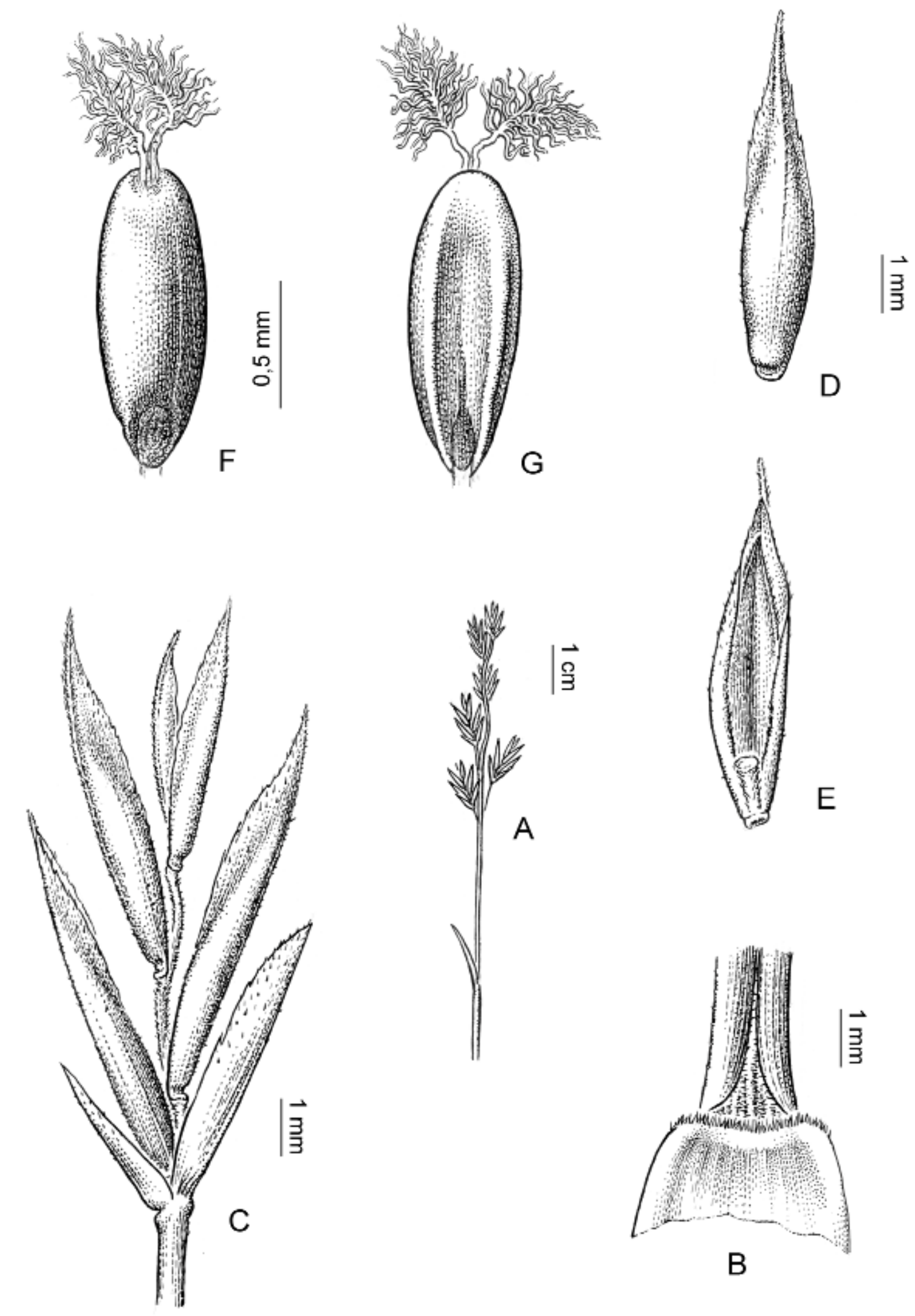

FIGURA 4. Festuca argentinensis. A. Inflorescencia. B. Zona ligular. C. Espiguilla. D. Antecio, vista dorsal. E. Antecio, vista ventral. F. Cariopsis, vista escutelar. G. Cariopsis, vista hilar. Reproducido de Türpe (1969: 248, fig. 21. - 2). 


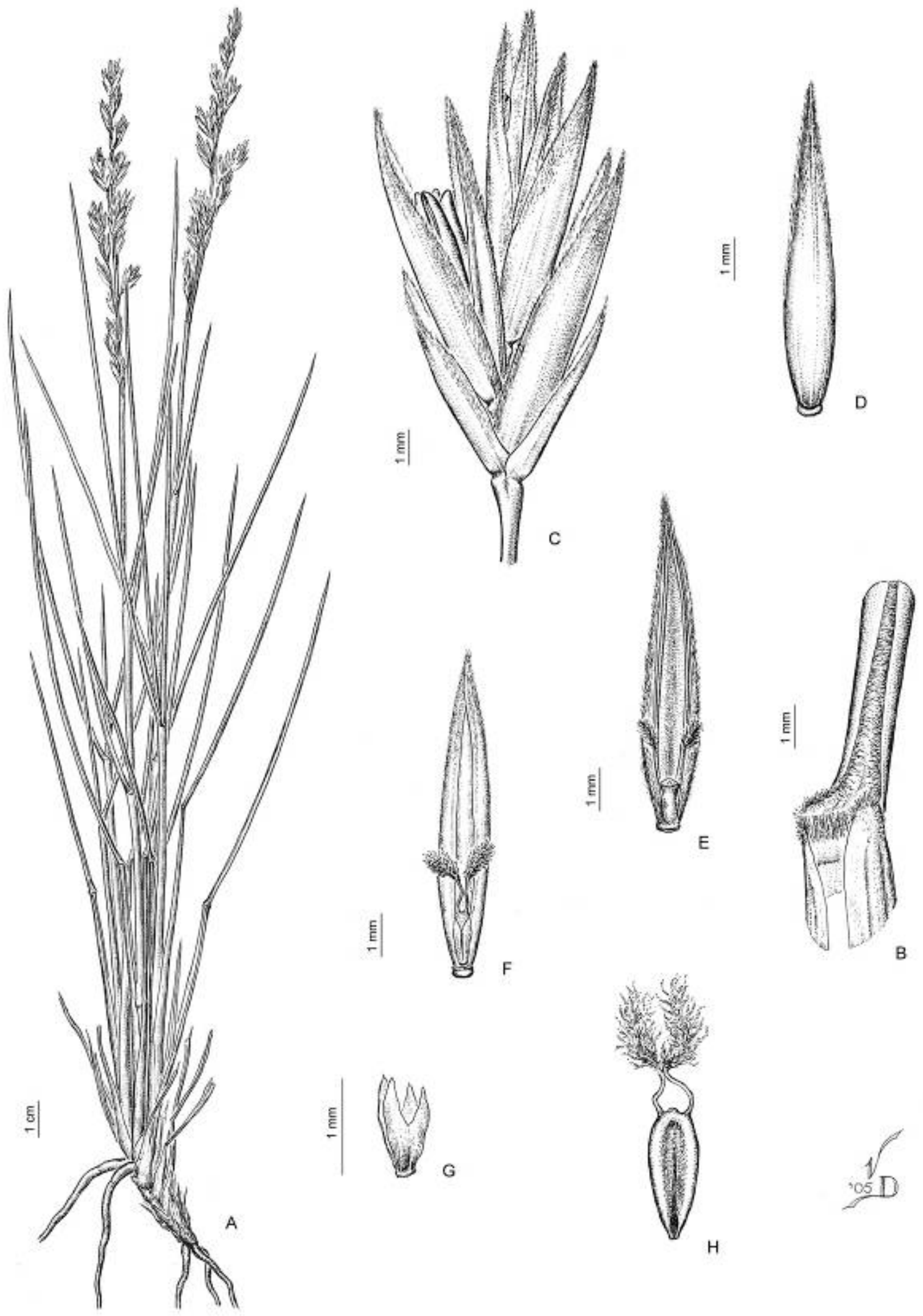

FIGURA 5. Festuca chrysophylla. A. Hábito e inflorescencia. B. Zona ligular. C. Espiguilla. D. Antecio, vista dorsal. E. Antecio, vista ventral. F. Pálea, vista ventral y estigma. G. Lodículas. H. Ovario. Reproducido de Ospina et al. (2013a: 6, fig. 2). 

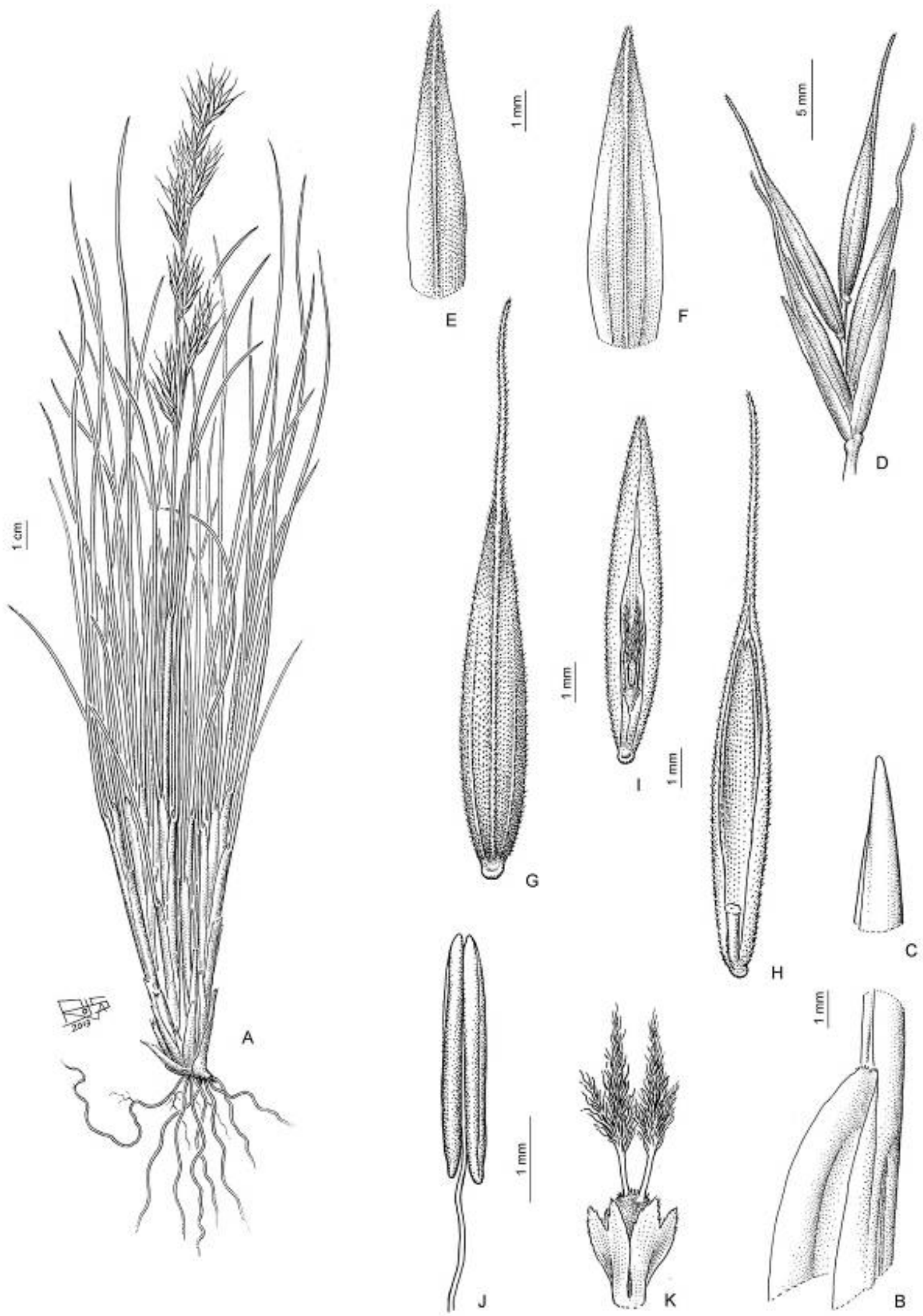

FIGURA 6. Festuca cirrosa. A. Hábito e inflorescencia. B. Zona ligular. C. Ápice de la lámina. D. Espiguilla. E. Gluma inferior, vista dorsal. F. Gluma superior, vista dorsal. G. Antecio, vista dorsal. H. Antecio, vista ventral. I. Pálea, vista ventral y estigma. J. Antera. K. Lodículas y ovario (Pisano et al. 6600, CONC). 


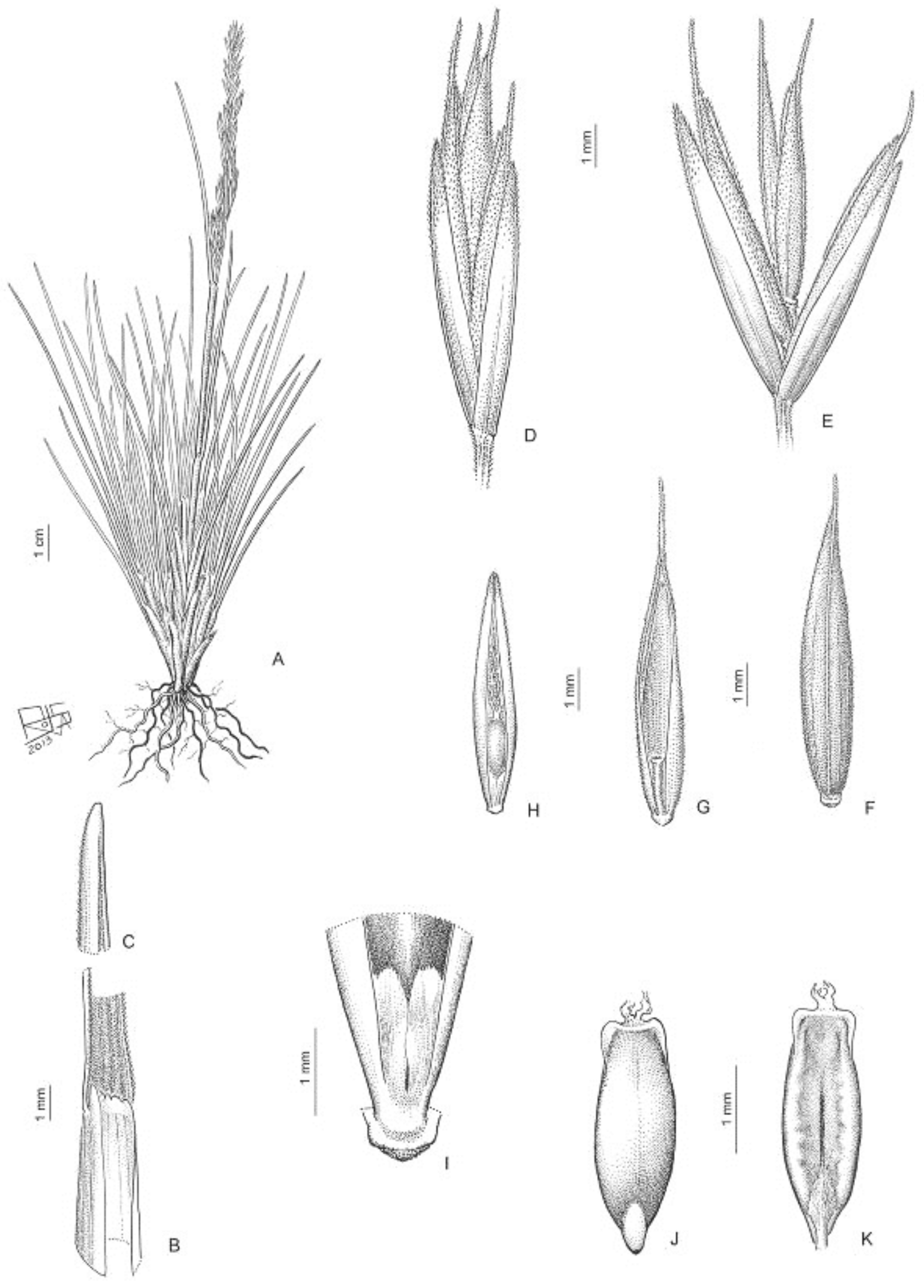

FIGURA 7. Festuca contracta. A. Hábito e inflorescencia. B. Zona ligular. C. Ápice de la lámina. D-E. Espiguilla. F. Antecio, vista dorsal. G. Antecio, vista ventral. H. Pálea, vista ventral y ovario. I. Lodículas. J. Cariopsis, vista escutelar. K. Cariopsis, vista hilar (Richardi \& Matthei 318, CONC). 


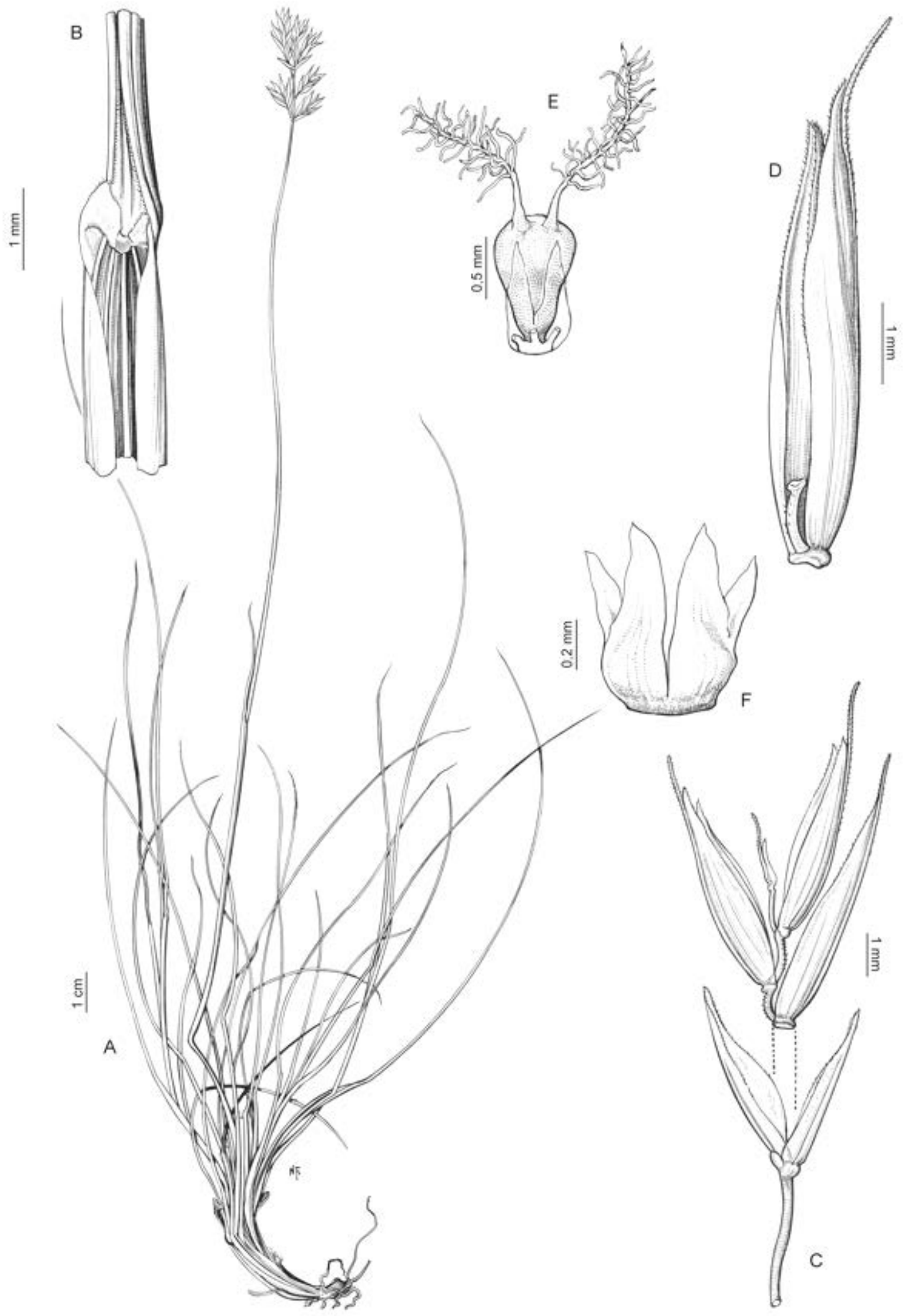

FIGURA 8. Festuca dissitiflora. A. Hábito e inflorescencia. B. Zona ligular. C. Espiguilla. D. Antecio, vista lateral. E. Lodículas. F. Ovario. Modificado de Catalán \& Müller (2012: 229). 


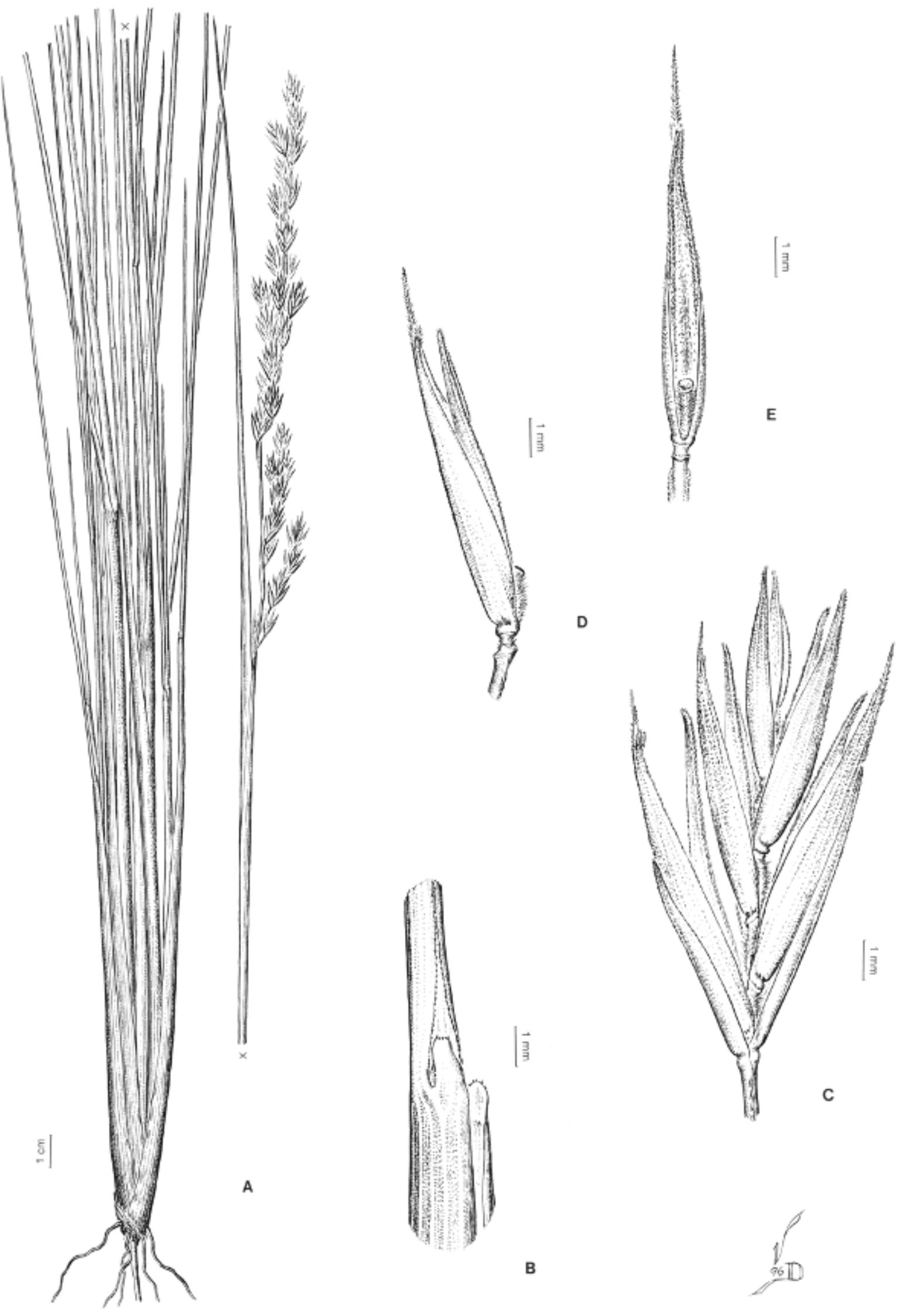

FIGURA 9. Festuca distichovaginata. A. Hábito e inflorescencia. B. Zona ligular. C. Espiguilla. D. Antecio, vista lateral. E. Antecio, vista ventral. Reproducido de Catalán \& Müller (2012: 230). 

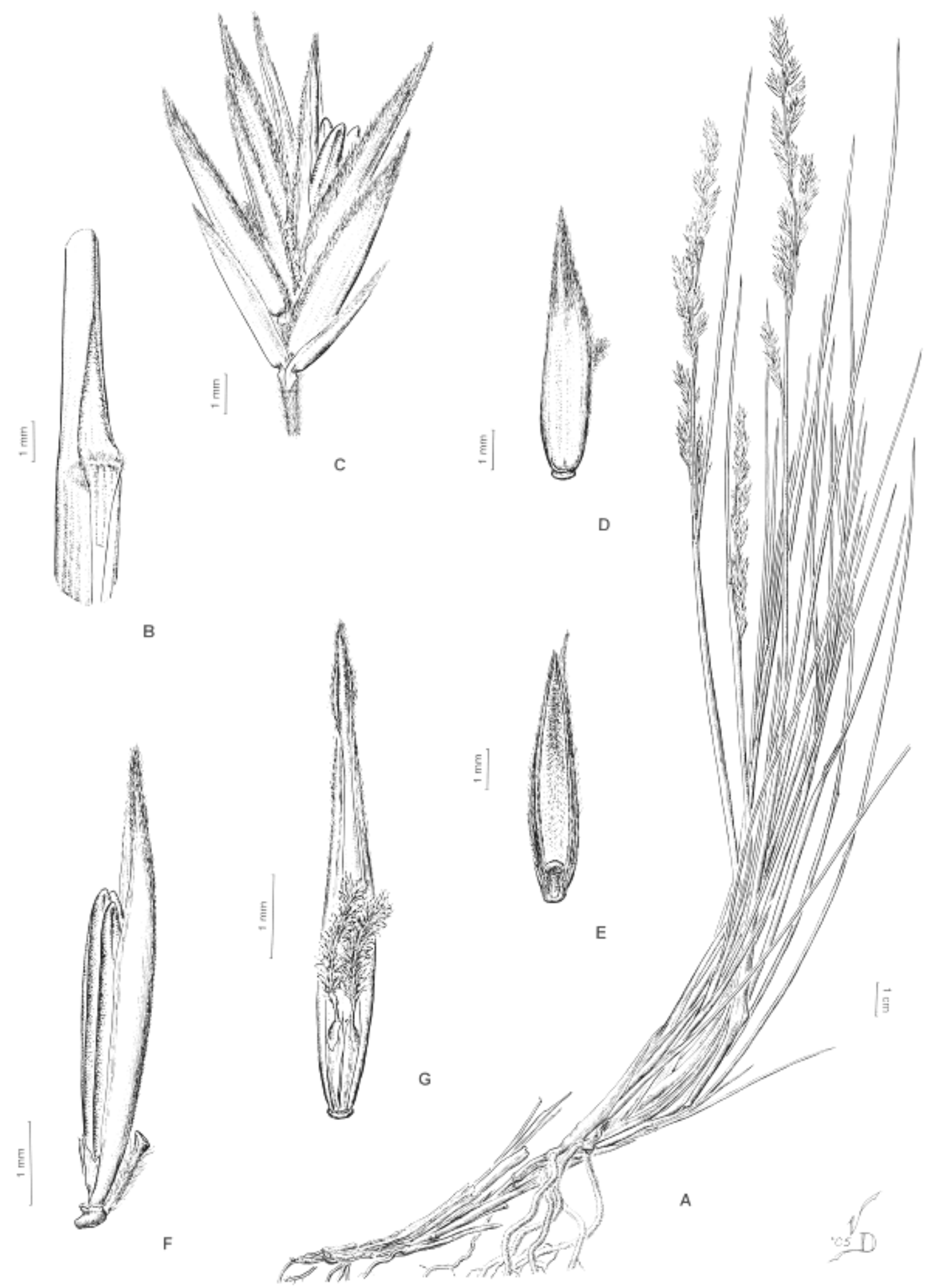

FIGURA 10. Festuca fiebrigii. A. Hábito e inflorescencia. B. Zona ligular. C. Espiguilla. D. Antecio, vista dorsal. E. Antecio, vista ventral. F. Pálea, vista lateral. G. Pálea, vista ventral y estigma. Reproducido de Catalán \& Müller (2012: 231). 


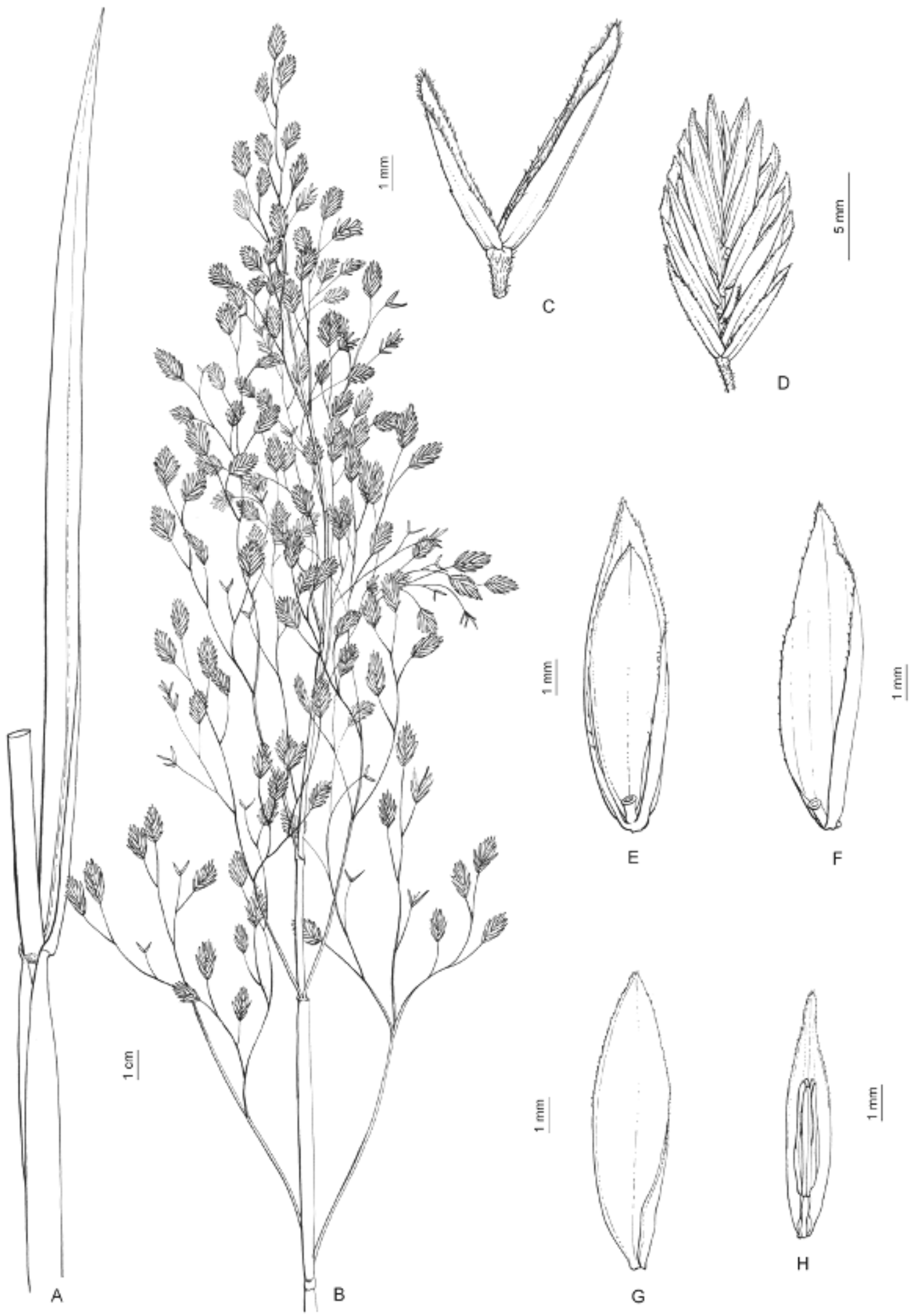

FIGURA 11. Festuca fimbriata. A. Porción de caña mostrando vaina y lámina. B. Inflorescencia. C. Glumas. D. Espiguilla. E. Antecio, vista ventral. F. Antecio, vista lateral. G. Lema, vista ventral. H. Paáea, vista ventral y estambres. Reproducido de Catalán \& Müller (2012: 232). 

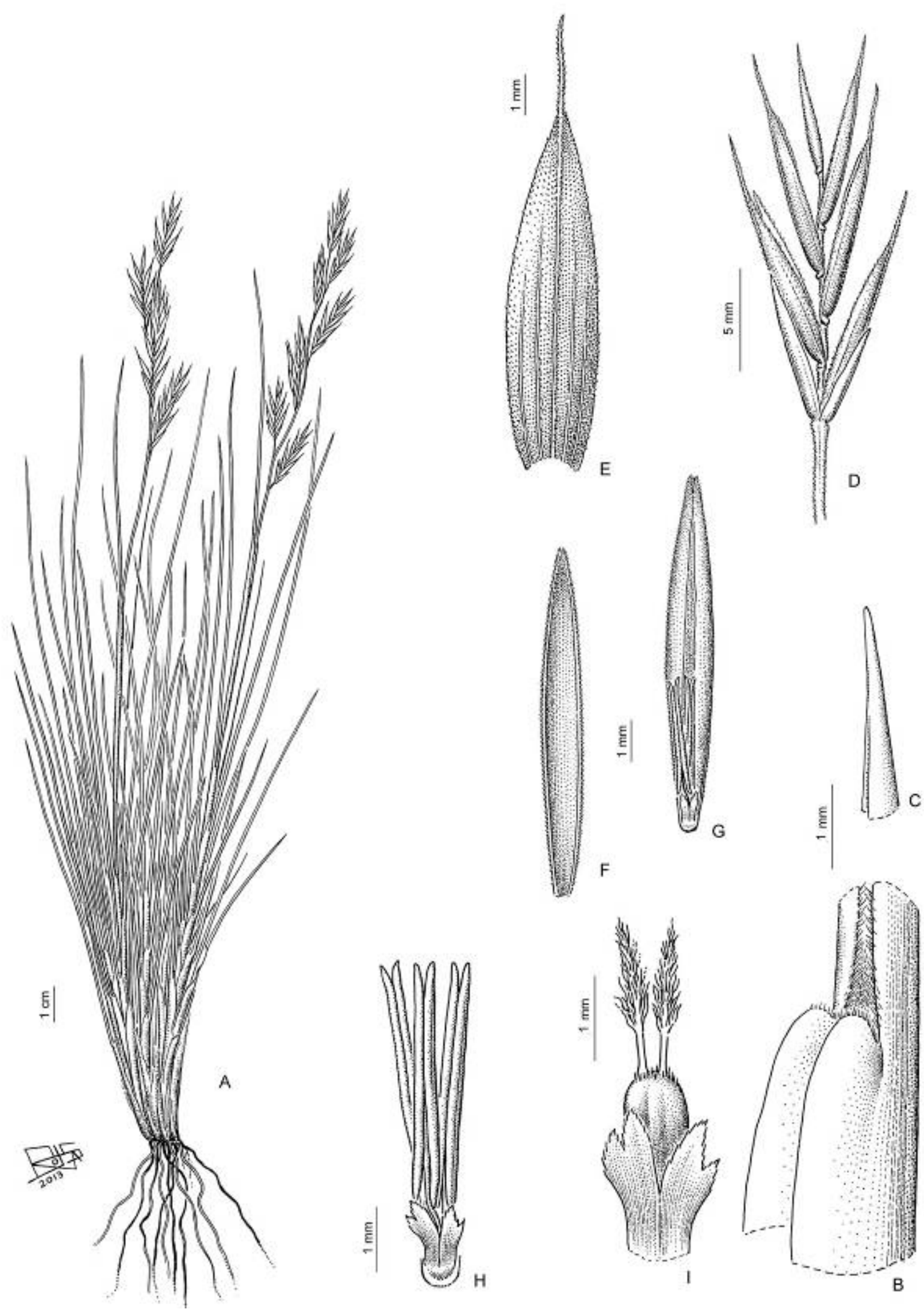

FIGURA 12. Festuca gracillima var. gracillima. A. Hábito e inflorescencia. B. Zona ligular. C. Ápice de la lámina.

D. Espiguilla. E. Lema, vista dorsal. F. Pálea, vista dorsal. G. Pálea, vista ventral y anteras. H. Anteras y lodículas. I. Lodículas y ovario (Magens \& Matthei 3447, CONC). 


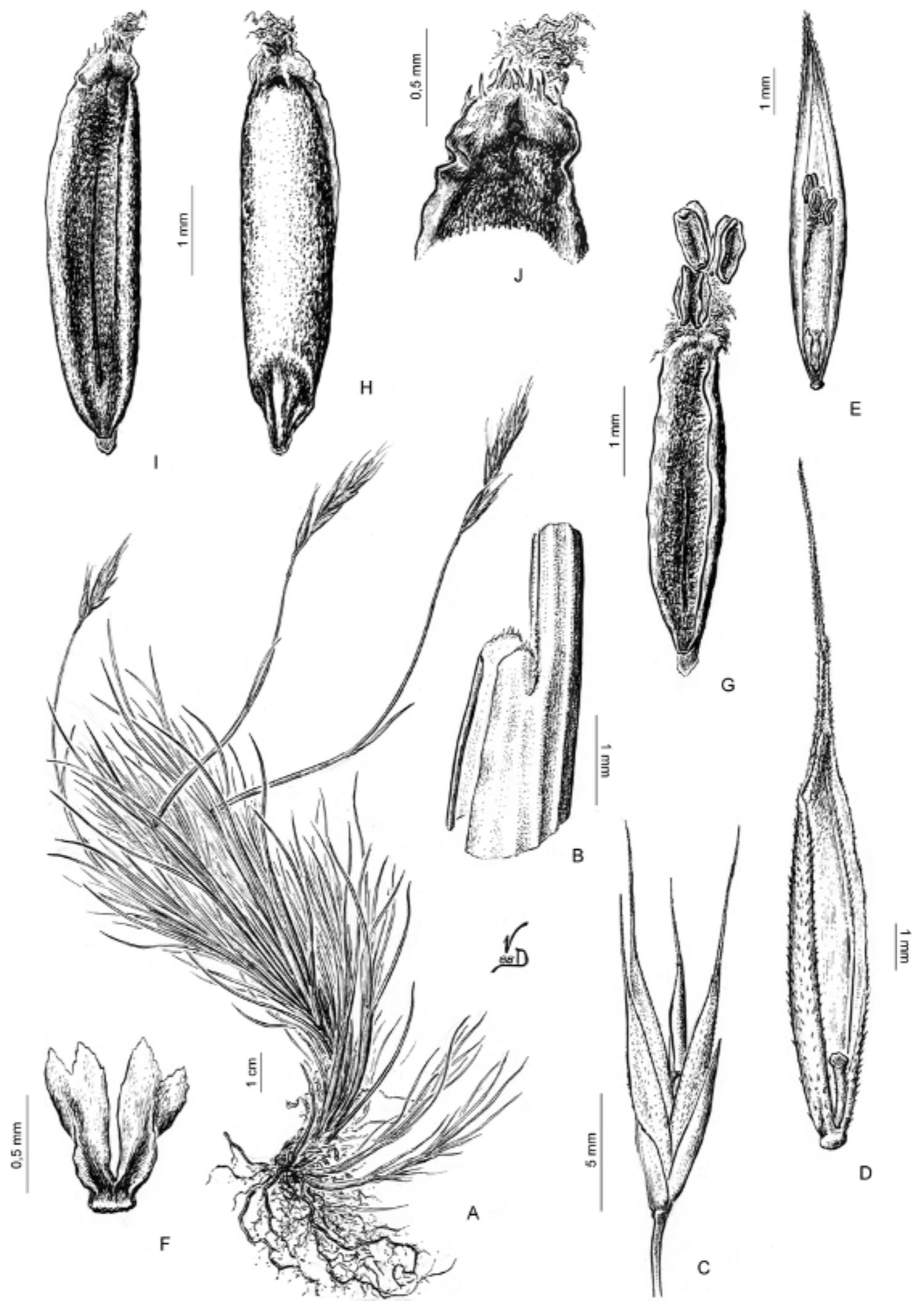

FIGURA 13. Festuca gracillima var. glacialis. A. Hábito e inflorescencia. B. Zona ligular. C. Espiguilla. D. Antecio, vista ventral. E. Pálea, vista ventral, con cariopsis, anteras y lodículas. F. Lodículas. G. Cariopsis, vista hilar, con las anteras junto a los estigmas. H. Cariopsis, vista escutelar. I. Cariopsis, vista hilar. J. Ápice de la cariopsis. Reproducido de Rúgulo \& Nicora (1988: 465). 


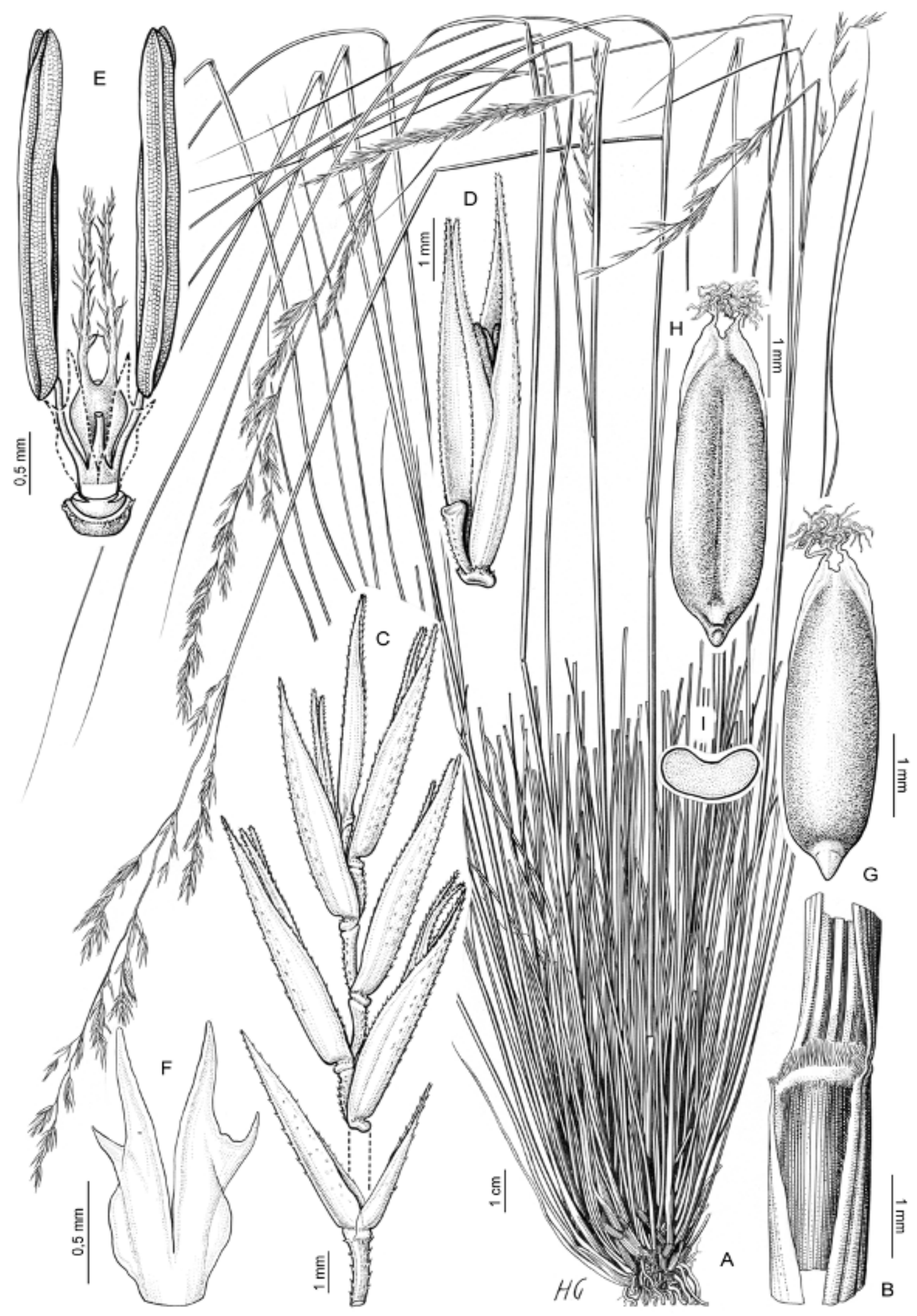

FIGURA 14. Festuca hieronymi. A. Hábito e inflorescencia. B. Zona ligular. C. Espiguilla. D. Antecio, vista lateral. E. Flor perfecta con lodículas indicadas. F. Lodículas. G. Cariopsis, vista escutelar. H. Cariopsis, vista hilar. I. Cariopsis, en corte transversal. Reproducido de Catalán \& Müller (2012: 234). 


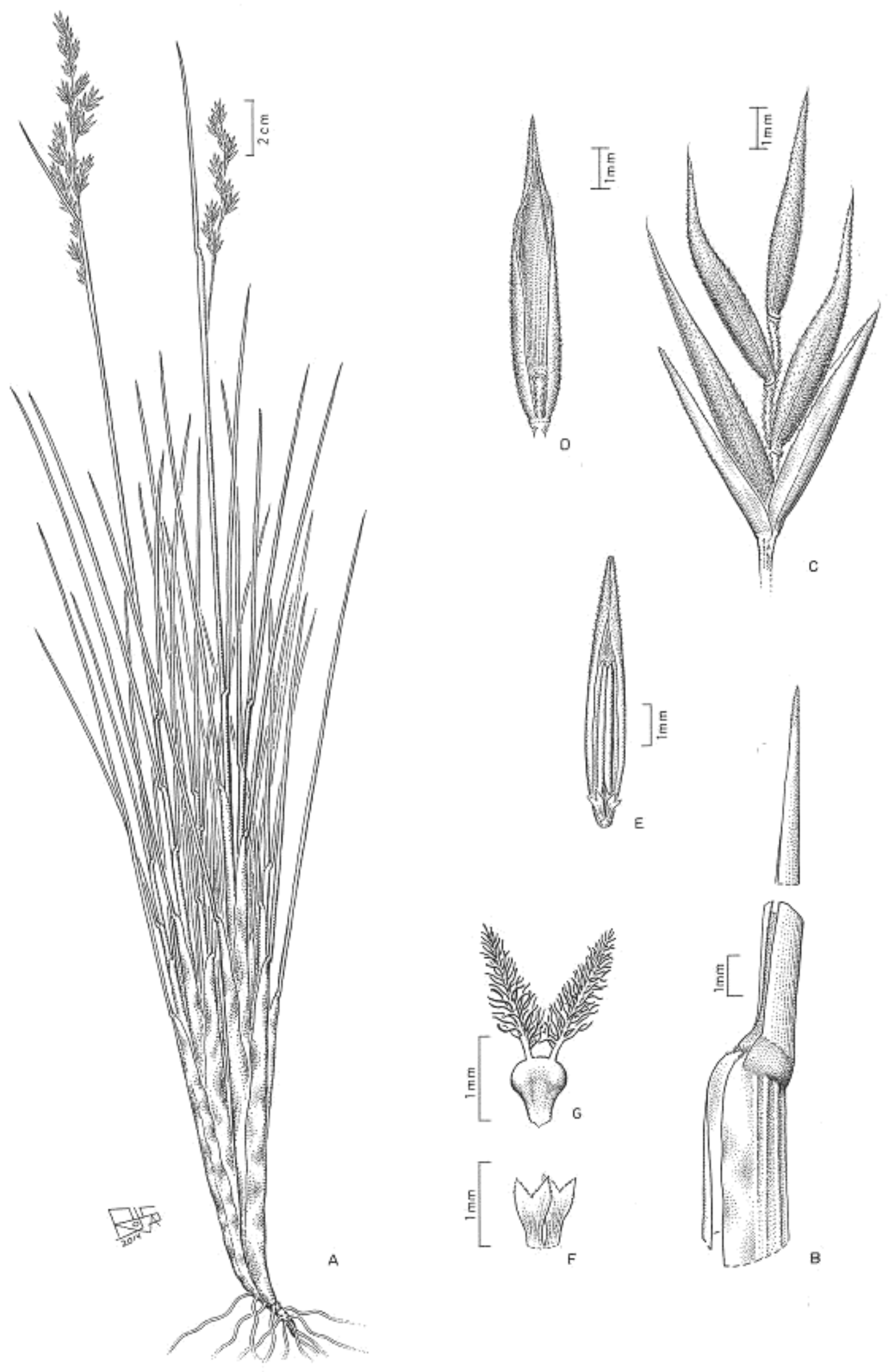

FIGURE 15. Festuca hypsophila. A. Hábito e inflorescencia. B. Zona ligular y ápice de la lámina. C. Espiguillas. D. Antecio, vista ventral. E. Pálea, visa ventral con anteras y lodículas. F. Lodículas G. Ovario (Nicora et al. 8583, SI). 


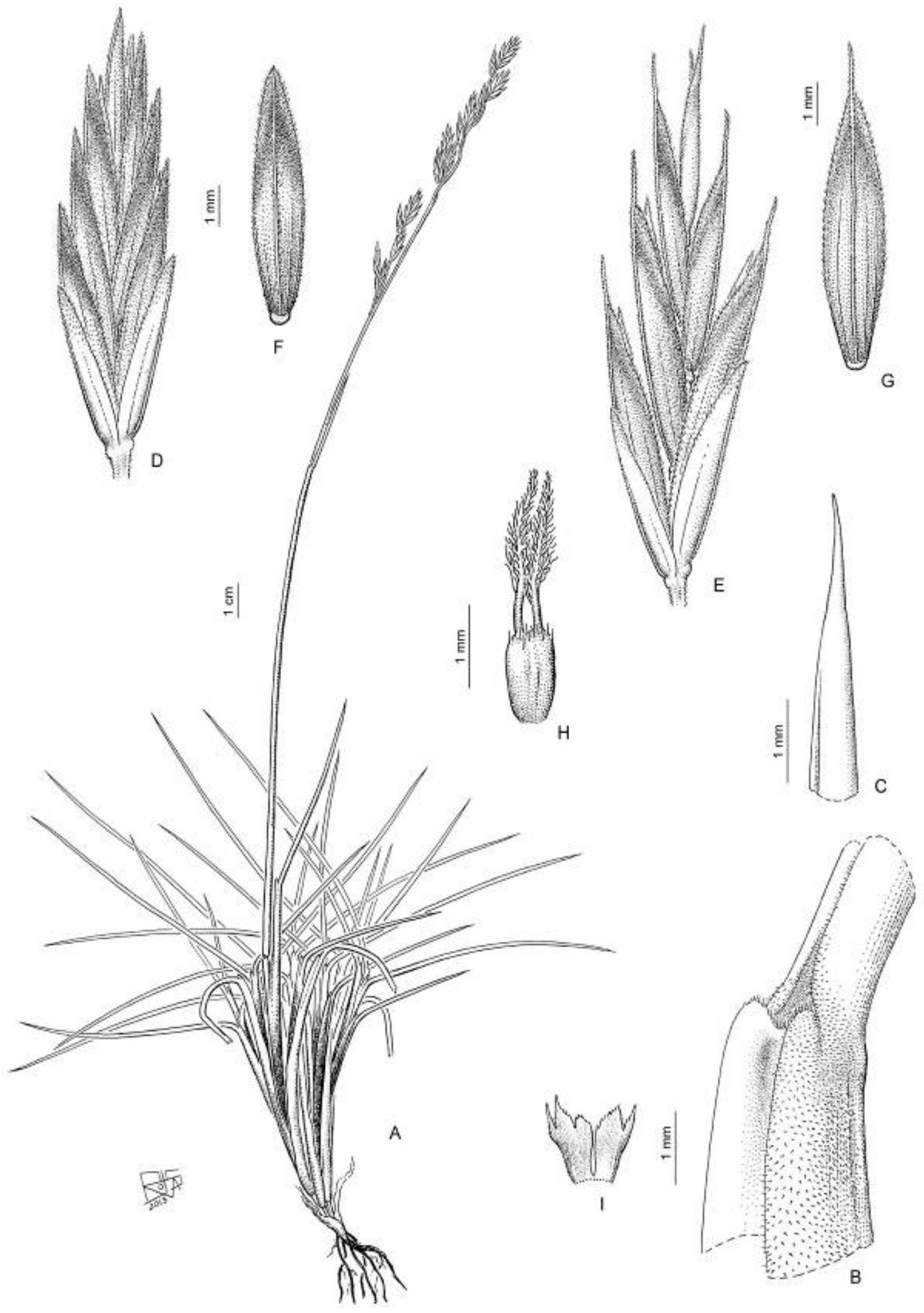

FIGURA 16. Festuca kurtziana. A. Hábito e inflorescencia. B. Zona ligular. C. Ápice de la lámina. D. Espiguilla sin arista. E. Espiguilla aristada. F. Antecio sin arista, vista dorsal. G. Antecio aristado, vista dorsal. H. Ovario. I. Lodículas. A-D y H-I, (Luebert et al. 2304, CONC). E-G, (Sede et al. 398g, SI). 

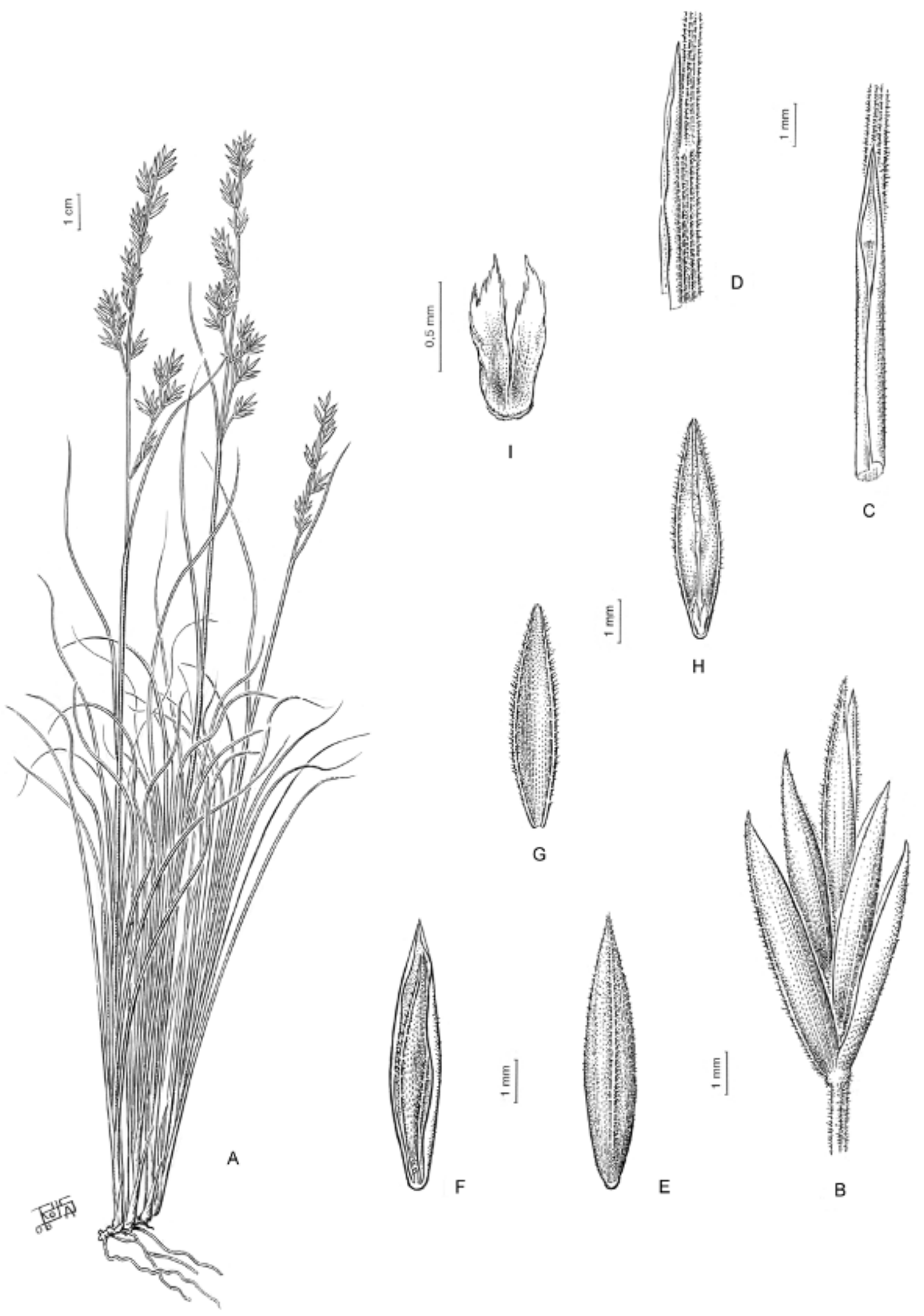

FIGURA 17. Festuca lilloi. A. Hábito e inflorescencia. B. Espiguilla. C. Zona ligular vista ventral. D. Zona ligular vista lateral. E. Antecio vista dorsal. F. Antecio vista ventral. G. Pálea vista dorsal. H. Pálea vista ventral. I. Lodículas. Reproducido de Catalán \& Müller (2012: 236). 

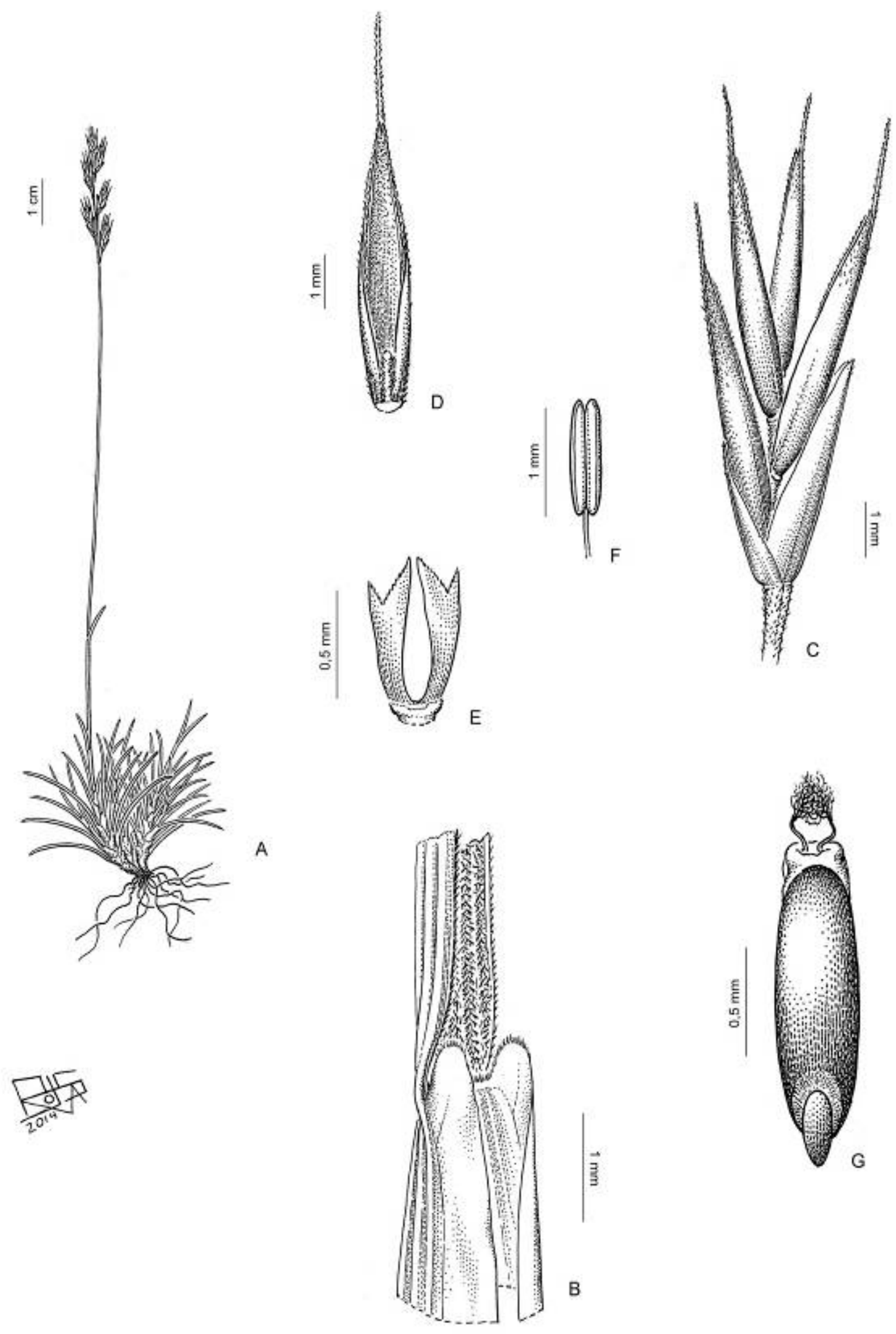

FIGURA 18. Festuca magellanica. A. Hábito e inflorescencia. B. Zona ligular. C. Espiguillas. D. Antecio, vista ventral. E. Lodículas. F. Antera. G. Cariopsis, vista escutelar (Peterson et al. 17271, SI). 


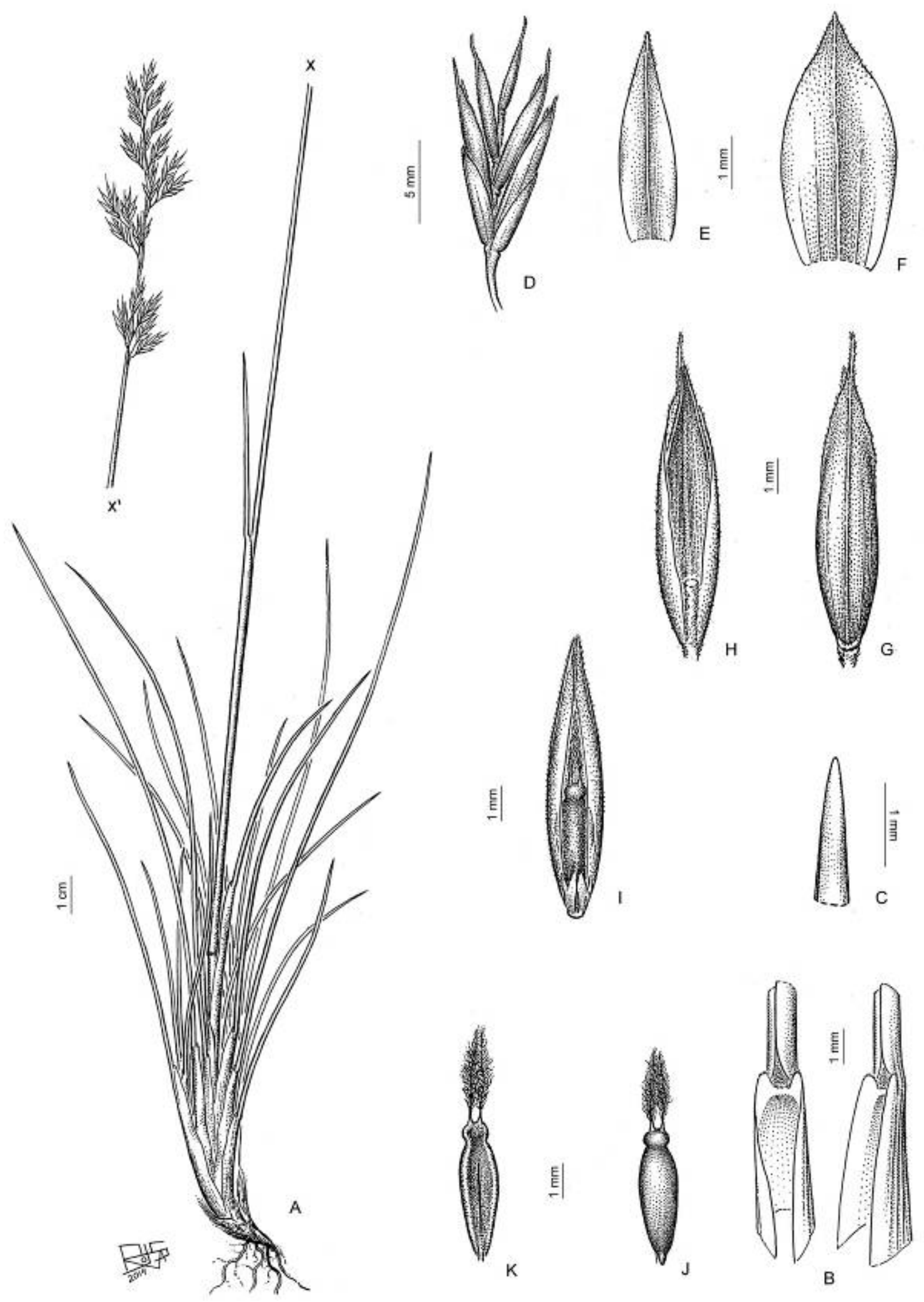

FIGURA 19. Festuca monticola. A. Hábito e inflorescencia. B. Zona ligular. C. Ápice de la lámina. D. Espiguilla. E. Gluma inferior, vista dorsal. F. Gluma superior, vista dorsal. G. Antecio, vista dorsal. H. Antecio, vista ventral. I. Pálea, vista ventral y ovario. J. Ovario, vista escutelar. K. Ovario, vista hilar (Werdermann 1268, SI). 

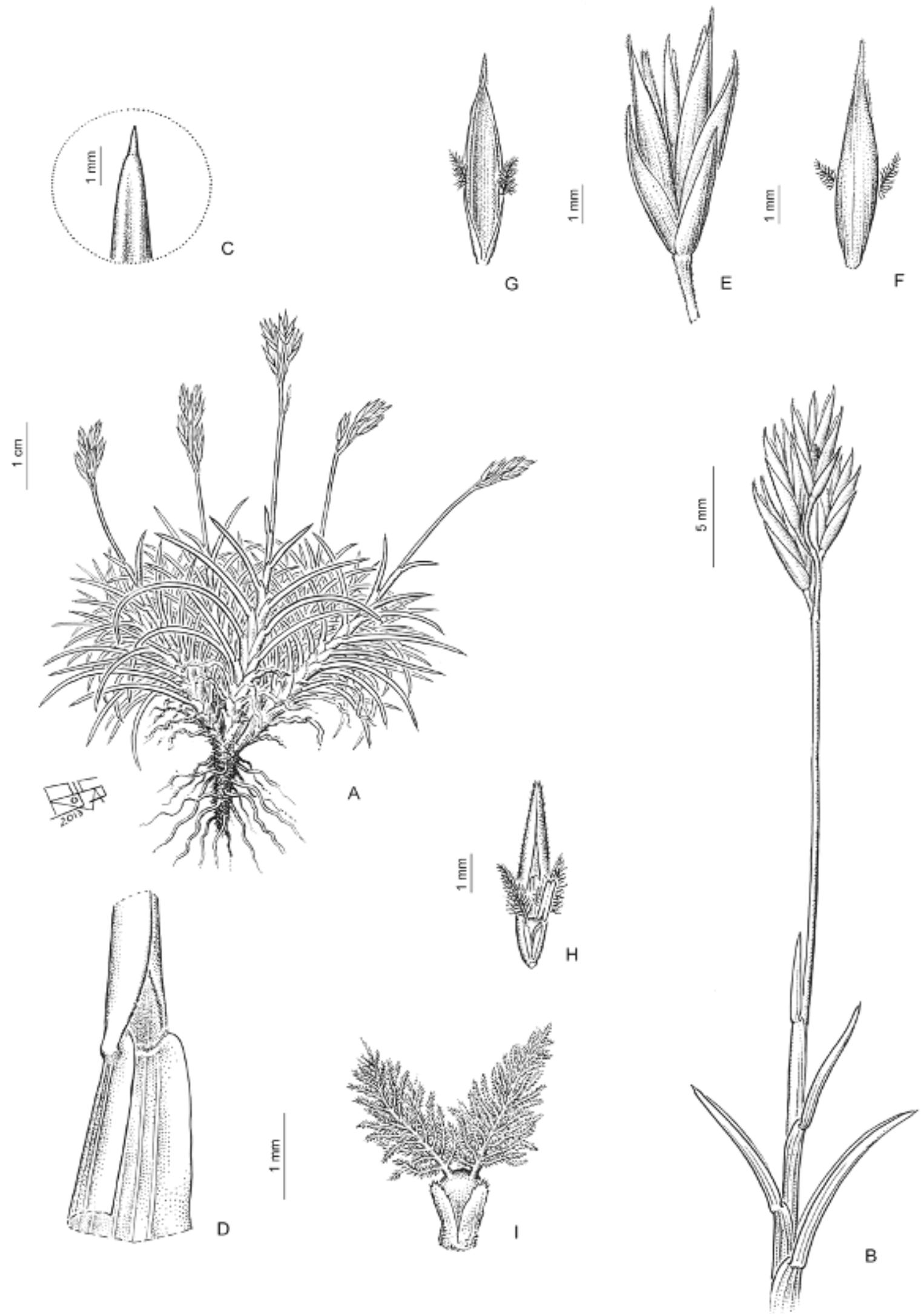

FIGURA 20. Festuca nardifolia. A. Hábito e inflorescencia. B. Caña florífera. C. Detalle del ápice de lámina. D. Zona ligular. E. Espiguilla. F. Antecio, vista dorsal. G. Antecio, vista ventral. H. Pálea, vista ventral con lodículas, ovario y anteras. I. Lodículas y ovario. Reproducido de Ospina et al. (2013b. Fig. 3 a-i. Pág. 169). 


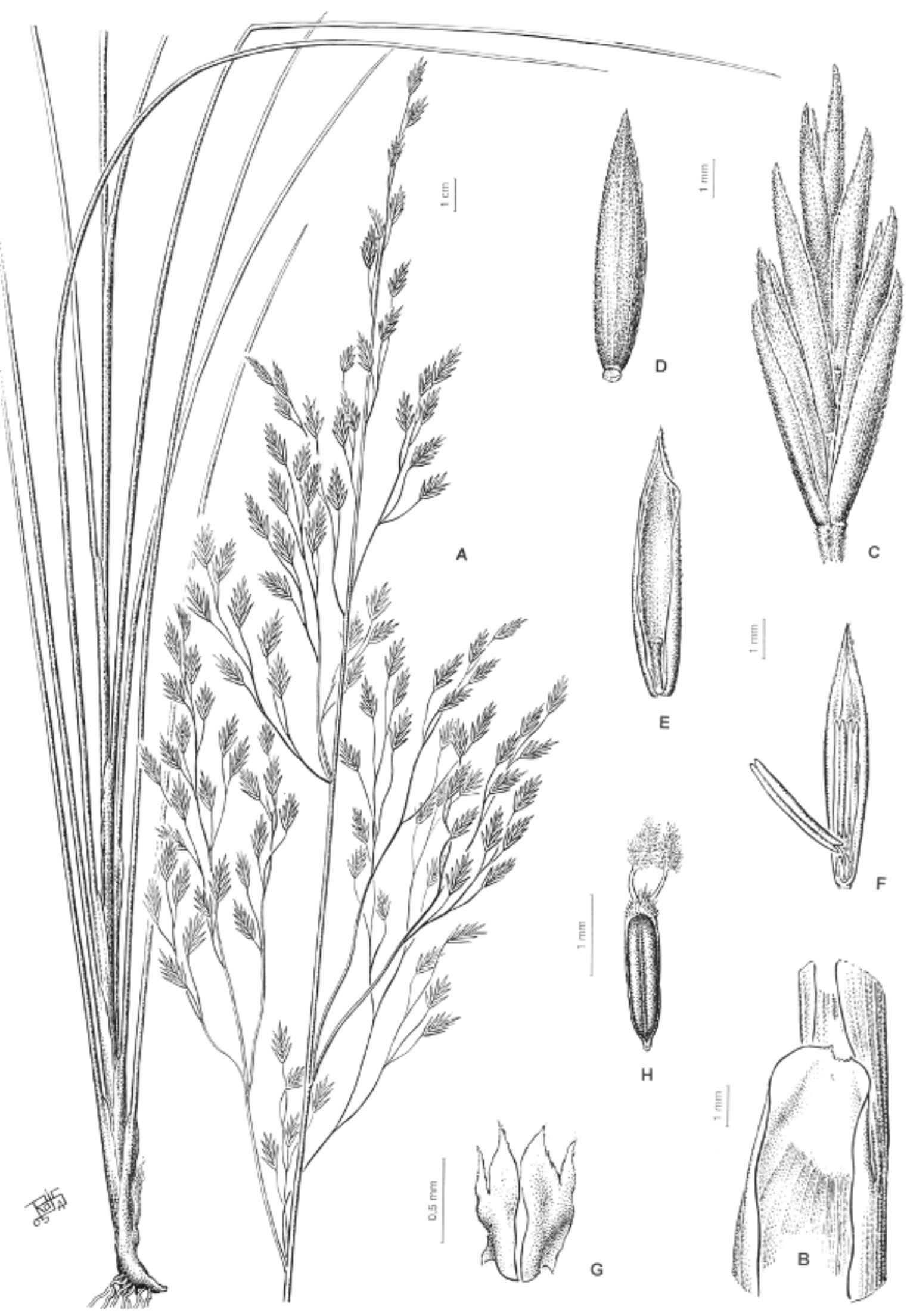

FIGURA 21. Festuca nemoralis. A. Hábito e inflorescencia. B. Zona ligular. C. Espiguilla. D. Antecio, vista dorsal. E. Antecio, vista ventral. F. Pálea, vista ventral con lodículas y anteras. G. Lodículas. H. Cariopsis, vista hilar. Reproducido de Catalán \& Müller (2012: 238). 

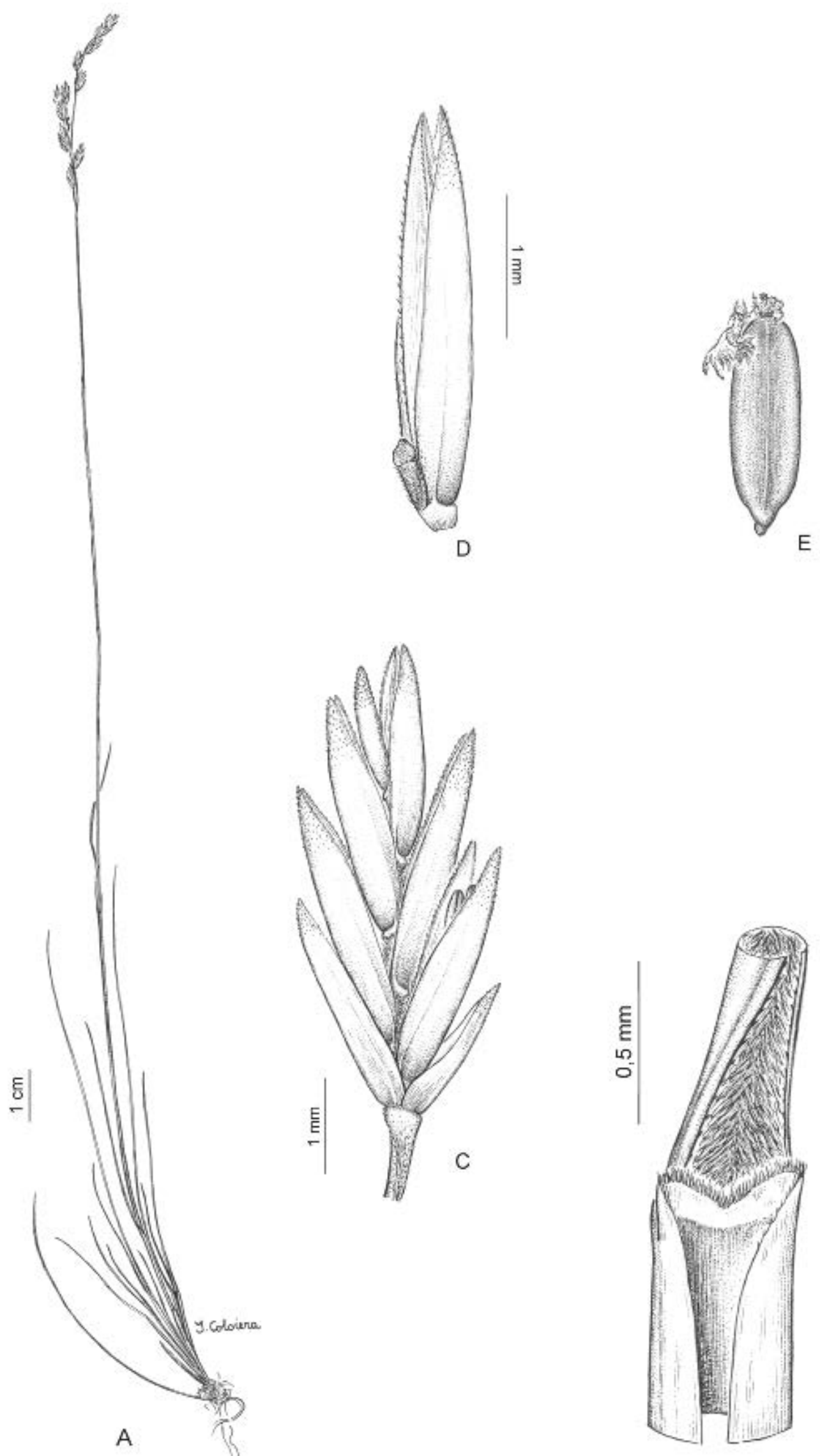

B

FIGURA 22. Festuca ovina var. tenuifolia. A. Hábito e inflorescencia. B. Zona ligular. C. Espiguilla. D. Antecio, vista lateral. E. Cariopsis, vista hilar. Reproducido de Catalán \& Müller (2012: 240). 


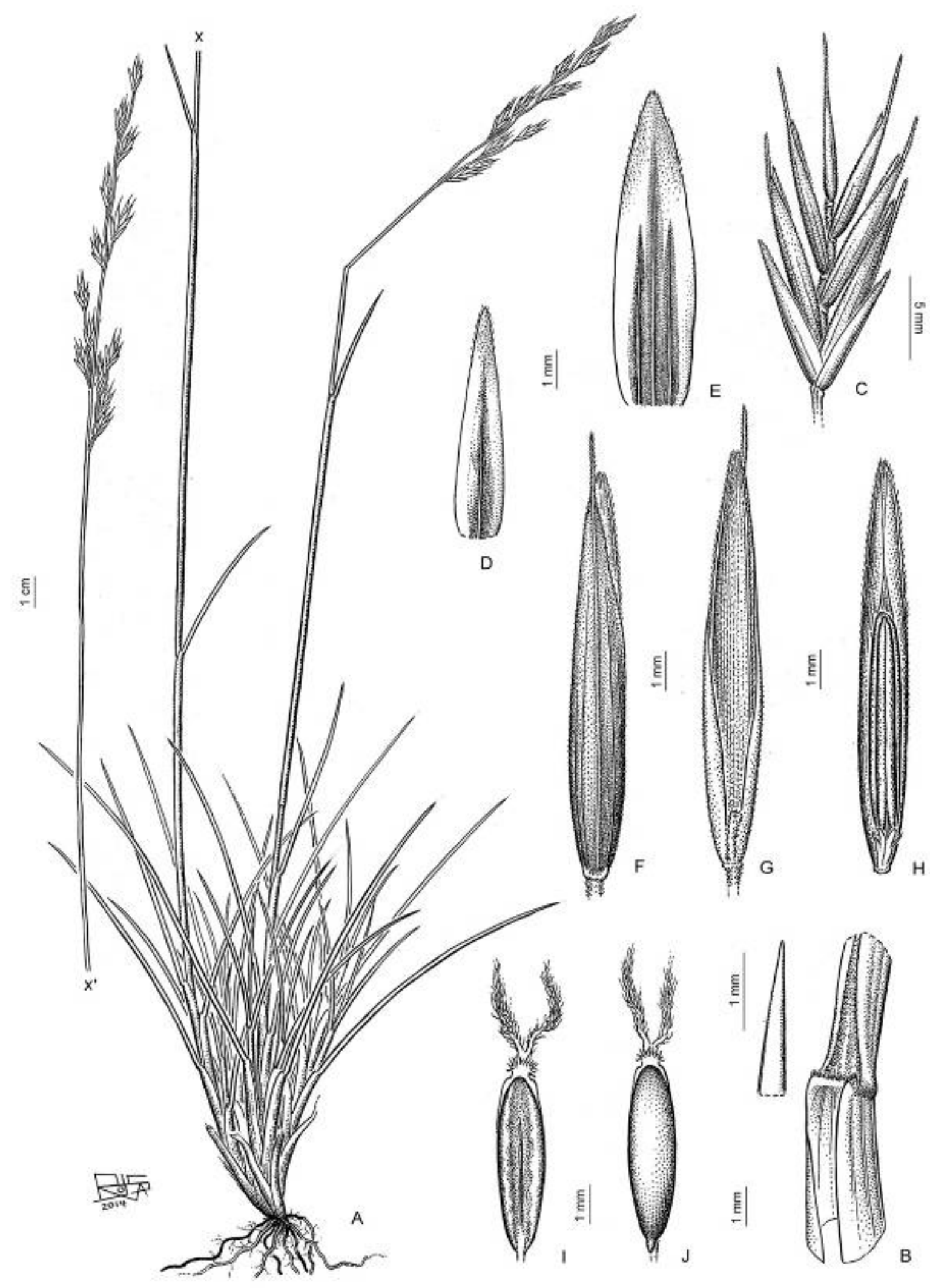

FIGURA 23. Festuca pallescens. A. Hábito e inflorescencia. B. Zona ligular y ápice de la lámina. C. Espiguilla. D. Gluma inferior, vista dorsal. E. Gluma superior, vista dorsal. F. Antecio, vista dorsal. G. Antecio, vista ventral. H. Pálea, vista ventral y anteras. I. Cariopsis, vista hilar. K. Cariopsis, vista escutelar. A-B, (Peterson et al. 17288, SI). C-J, (Magens 3704, CONC). 


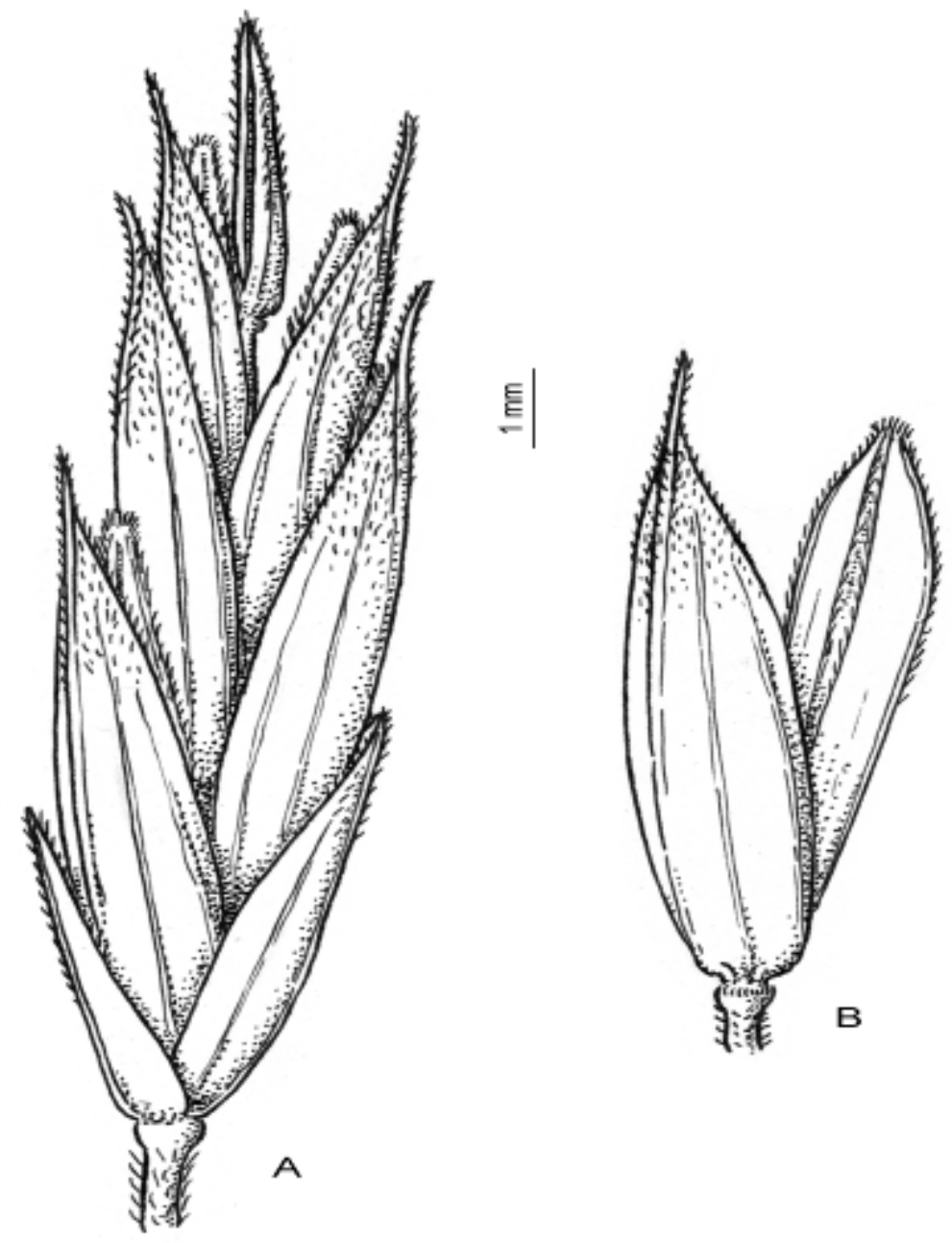

FIGURA 24. Festuca pampeana. A. Espiguilla. B. Antecio. Reproducido de Catalán \& Müller (2012: 24241). 

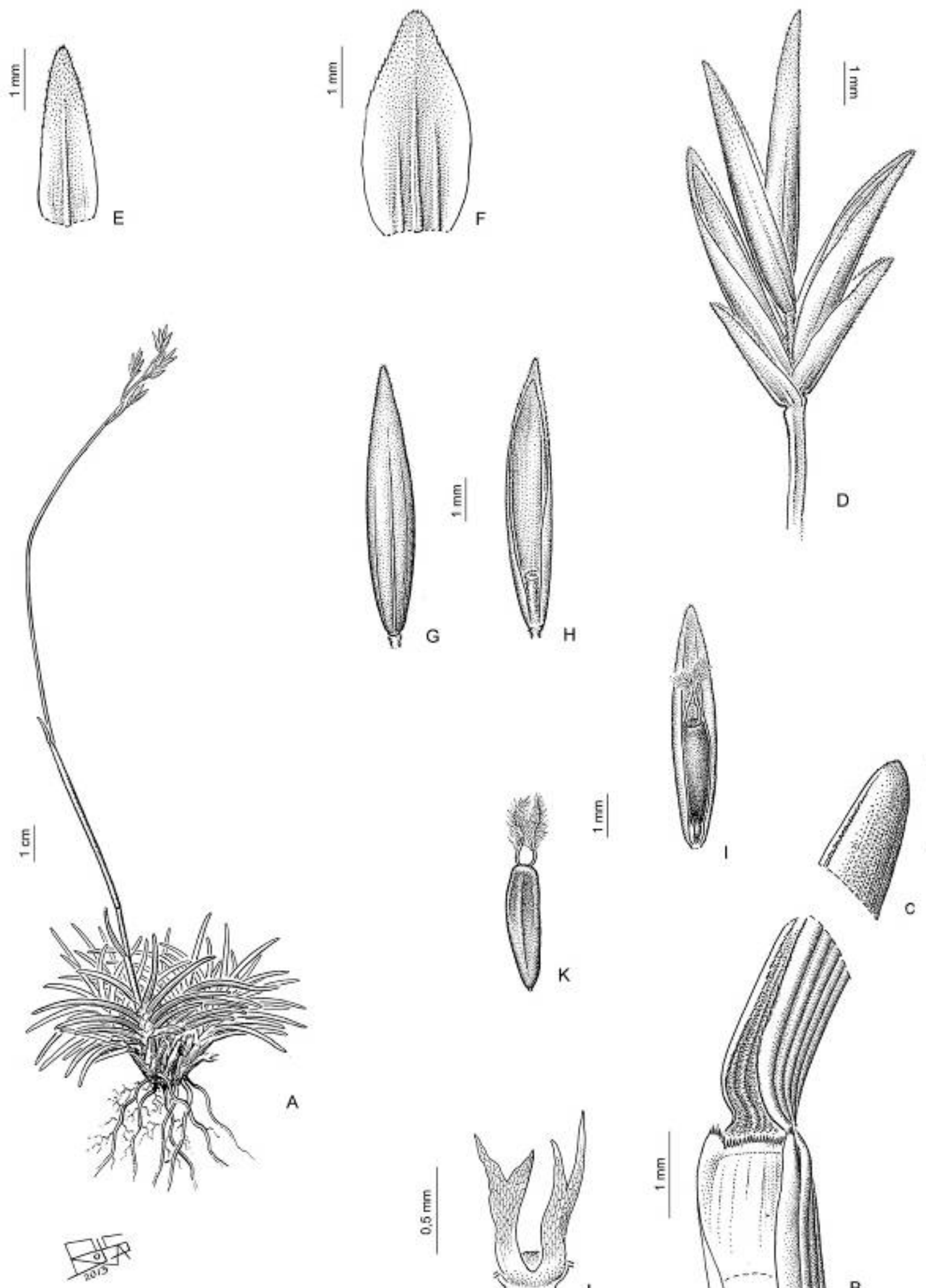

H
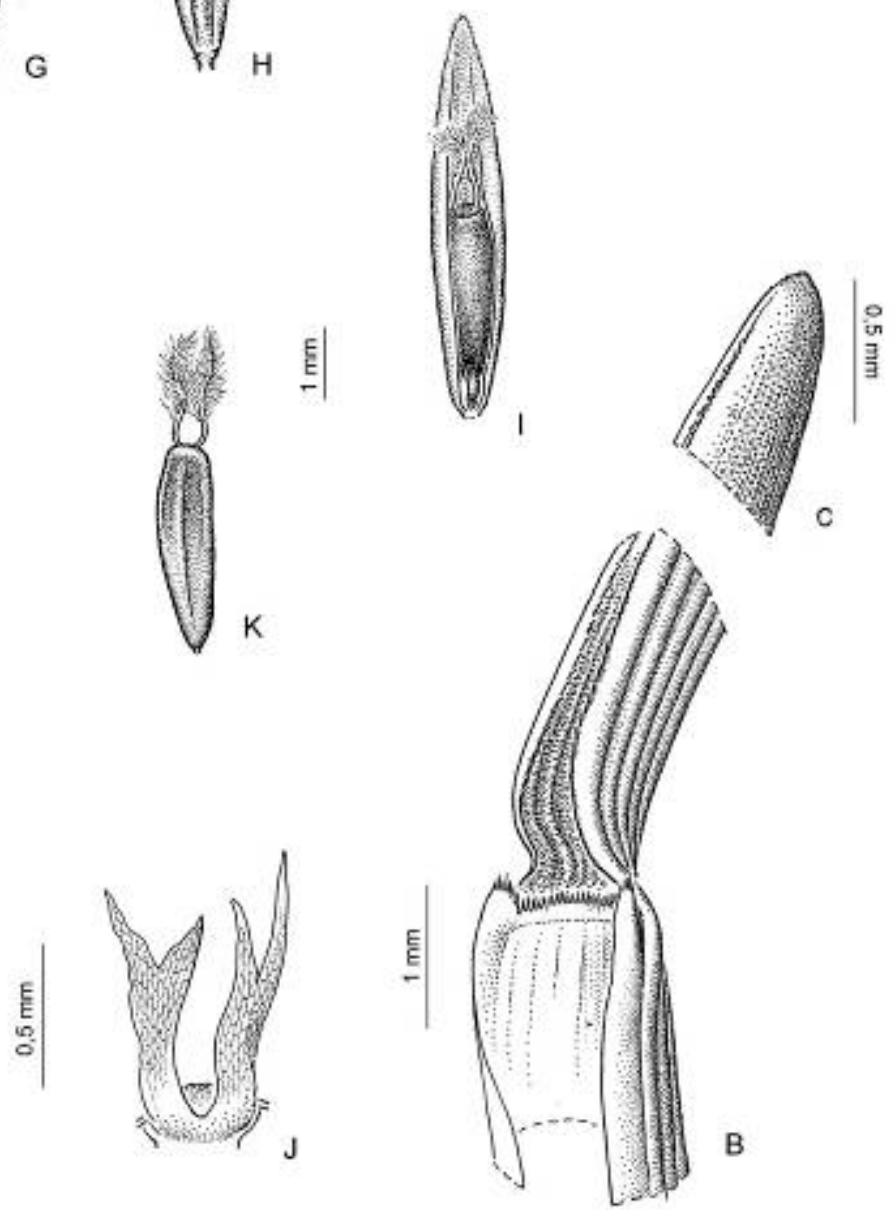

FIGURA 25. Festuca panda. A. Hábito e inflorescencia. B. Zona ligular. C. Ápice de la lámina. D. Espiguilla. E. Gluma inferior, vista dorsal. F. Gluma superior, vista dorsal. G. Antecio, vista dorsal. H. Antecio, vista ventral. I. Pálea, vista ventral y ovario. J. Lodículas. K. Ovario (Jiles 3382c, CONC 54953). 


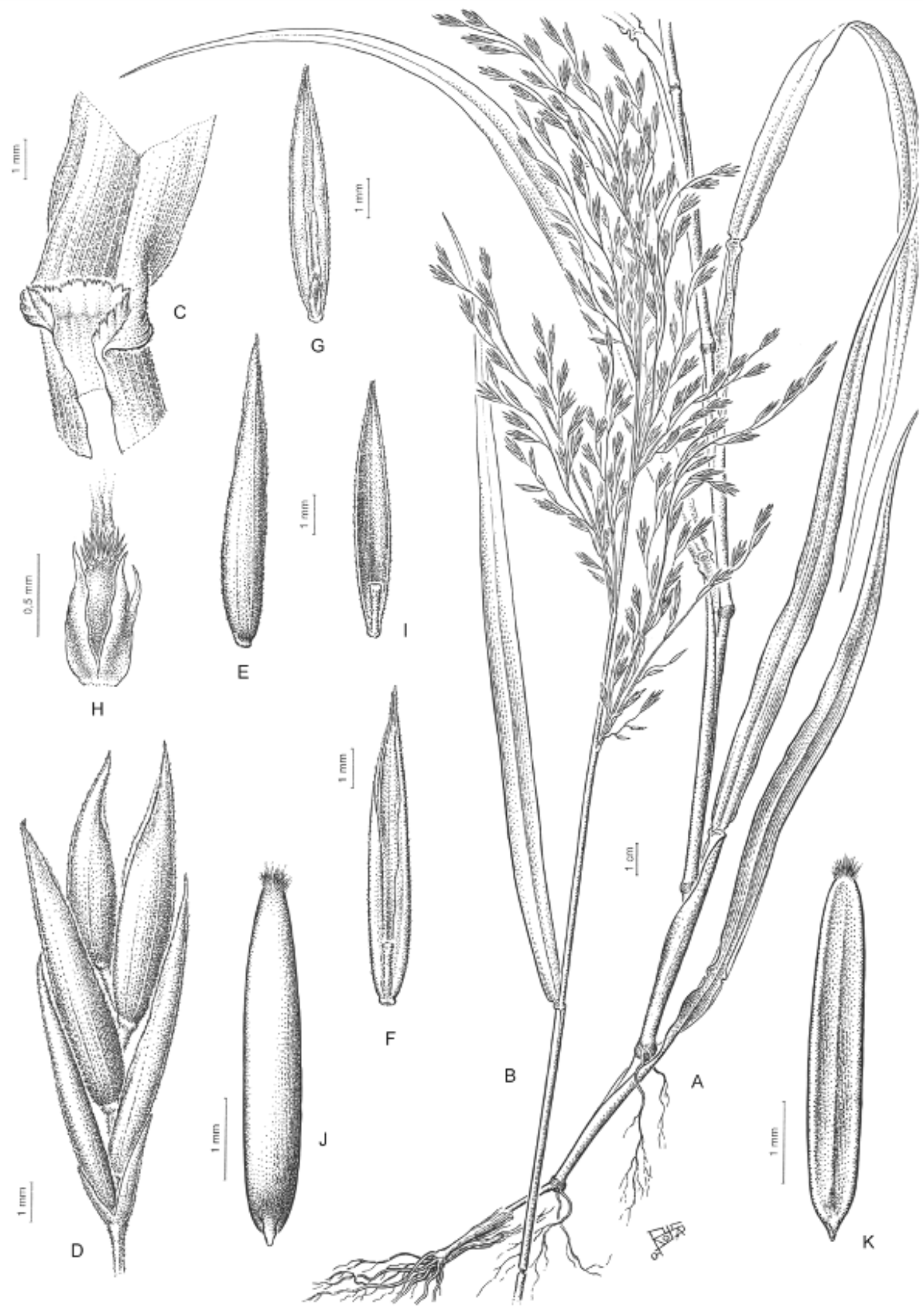

FIGURA 26. Festuca parodiana. A. Hábito. B. Inflorescencia. C. Zona ligular. D. Espiguilla. E. Antecio, vista dorsal. F. Antecio, vista ventral. G. Pálea, vista ventral con lodículas. H. Porción del gineceo y lodículas. I. Pálea, vista dorsal. J. Cariopsis, vista escutelar. K. Cariopsis, vista hilar. Reproducido de Catalán \& Müller (2012: 248). 


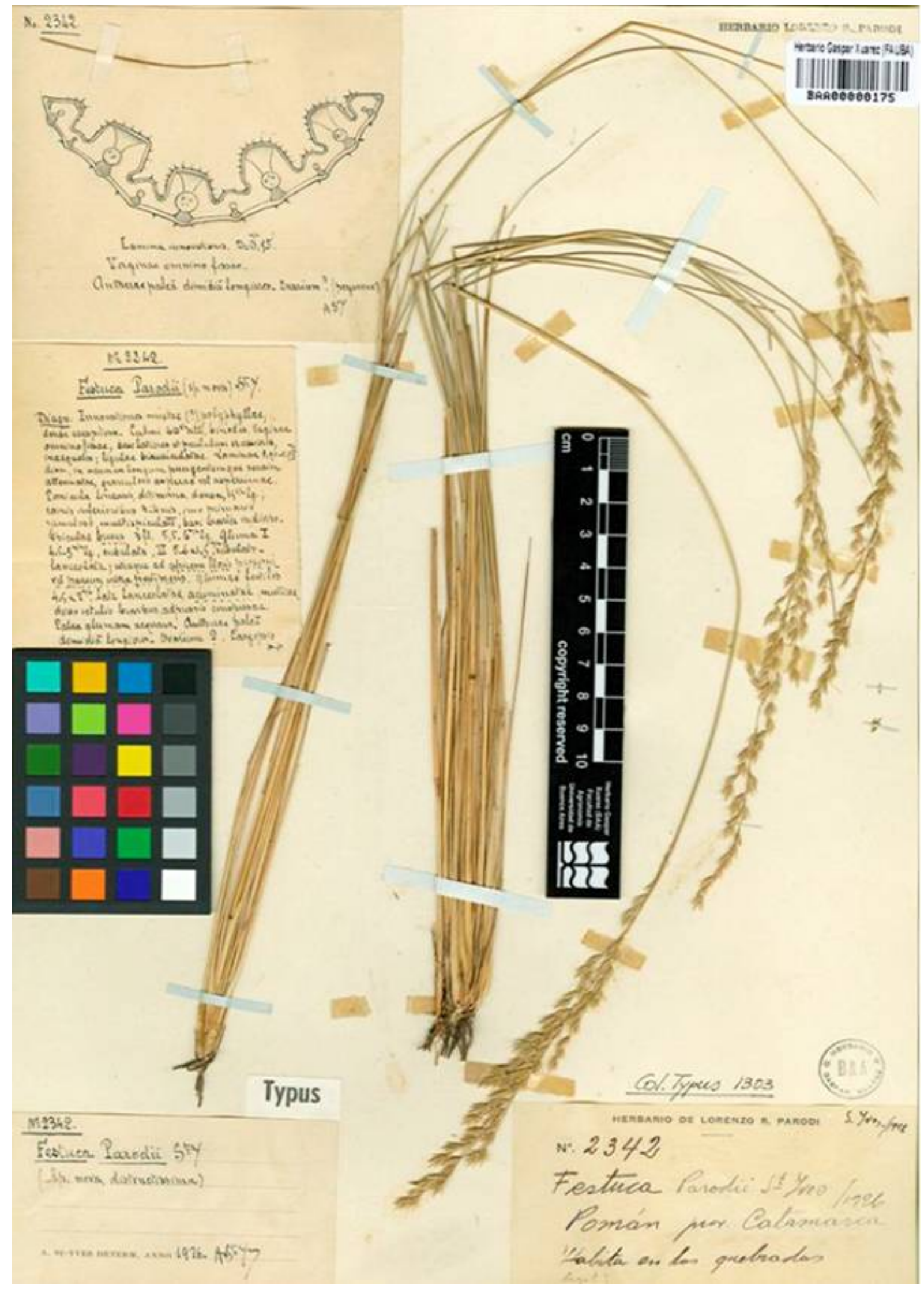

FIGURA 27. Festuca parodii. Imagen del holotipo: L. R. Parodi 2342 depositado en el Herbario Gaspar Xuárez
Universidad
de
Buenos
Aires
(BAA
00000175).
Reproducido de

http://plants.jstor.org/stable/10.5555/al.ap.specimen.baa00000175. 


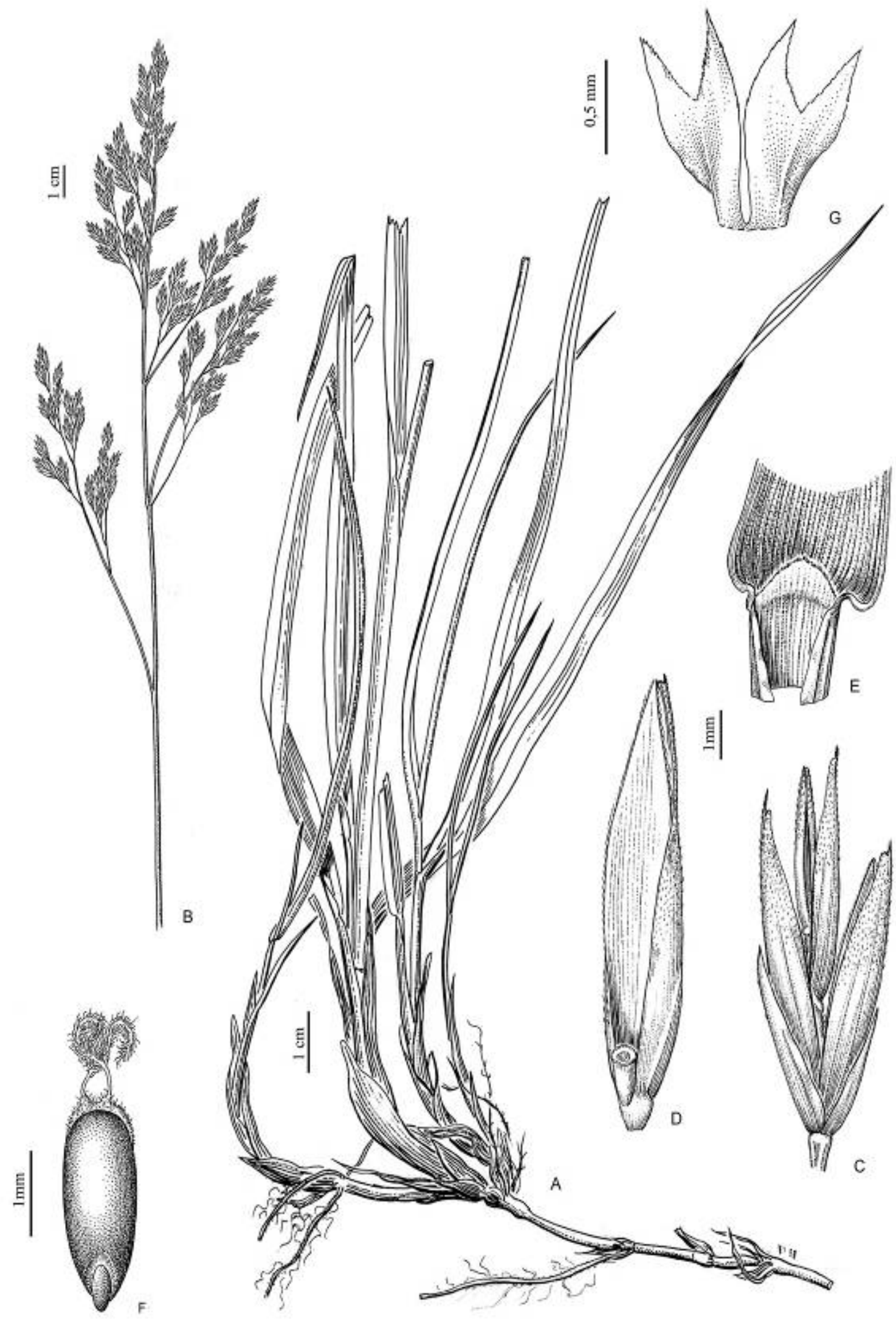

FIGURA 28. Festuca purpurascens. A. Hábito. B. Inflorescencia. C. Espiguilla. D. Antecio, vista ventral. E. Zona ligular. F. Cariopsis. G. Lodículas. A, C-E. Reproducido de Nicora (1978: 98, fig. 56), B, F-G (Peterson et al. 17401, SI). 

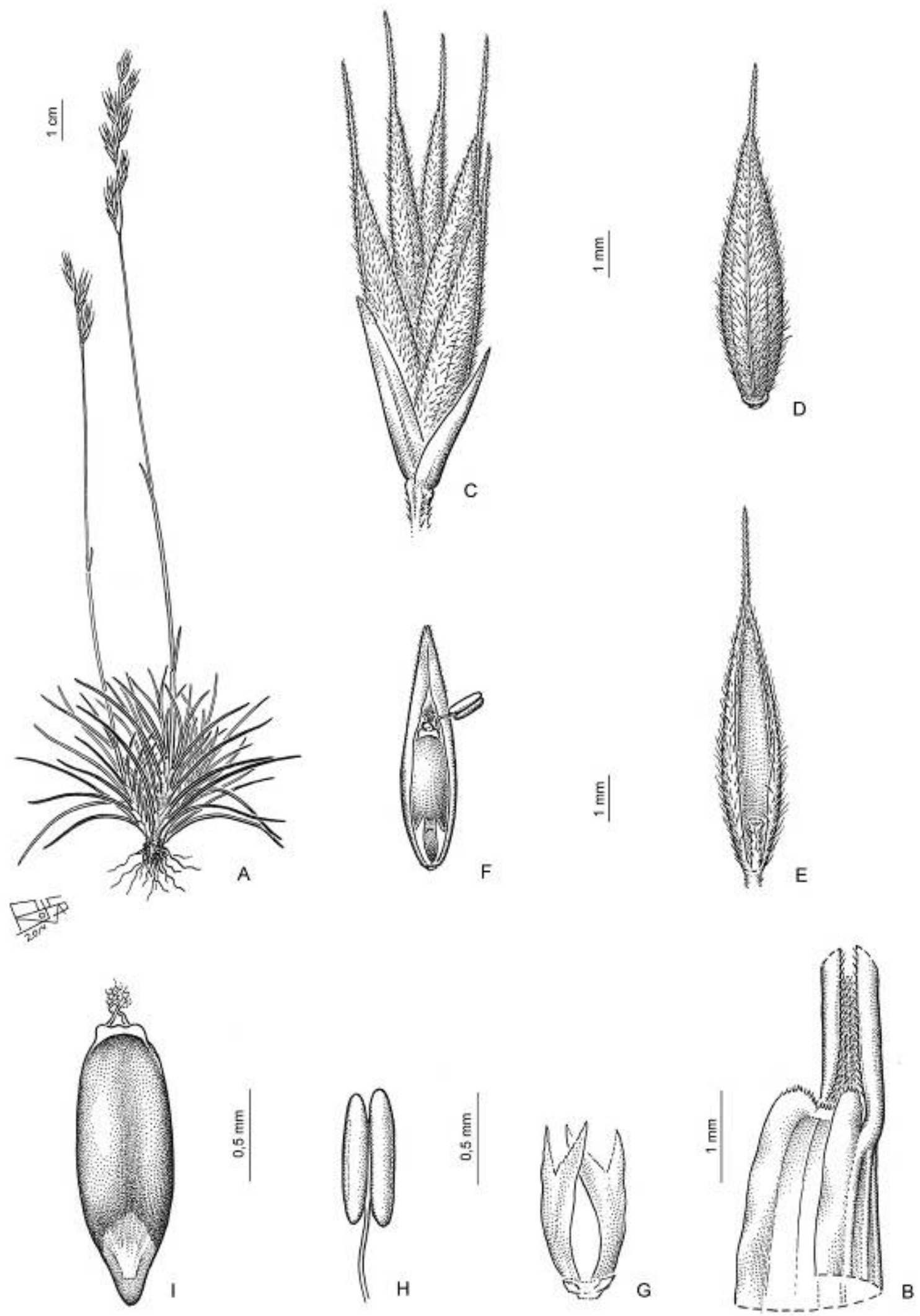

FIGURA 29. Festuca pyrogea. A. Hábito e inflorescencia. B. Zona ligular. C. Espiguilla. D. Antecio, vista dorsal. E. Antecio, vista ventral. F. Pálea, vista ventral con ovario y anteras. G. Lodículas. H. Antera. I. Cariopsis (Roig et al. s.n. T.B.P.A.-FIT $2711, \mathrm{SI})$. 


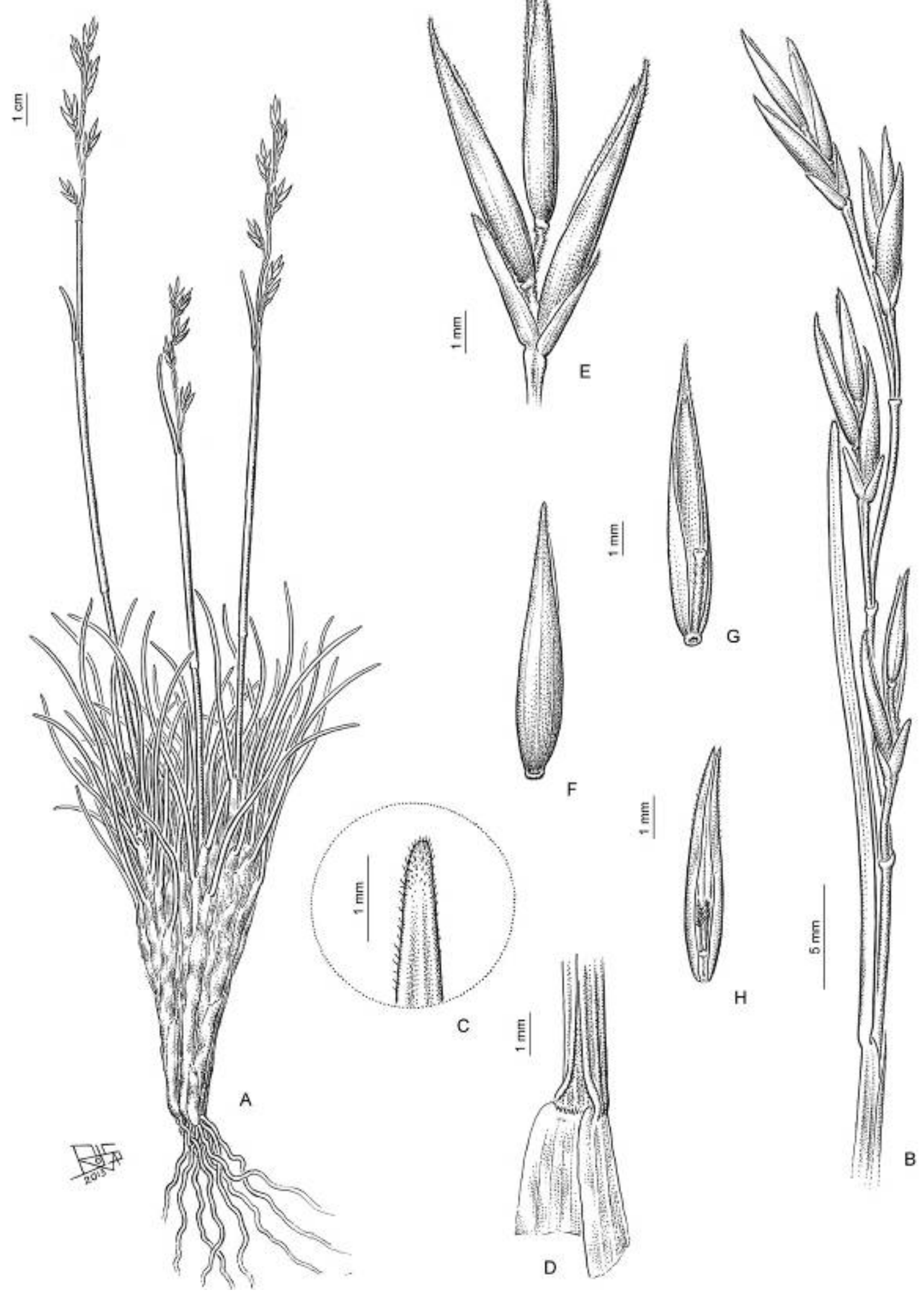

FIGURA 30. Festuca rigescens. A. Hábito e inflorescencia. B. Inflorescencia. C. Ápice de la lámina. D. Zona ligular. E. Espiguilla. F. Antecio, vista dorsal. G. Antecio, vista ventral. H. Pálea, vista ventral con ovario. Reproducido de Ospina et al. (2013b: 164, fig. 1). 

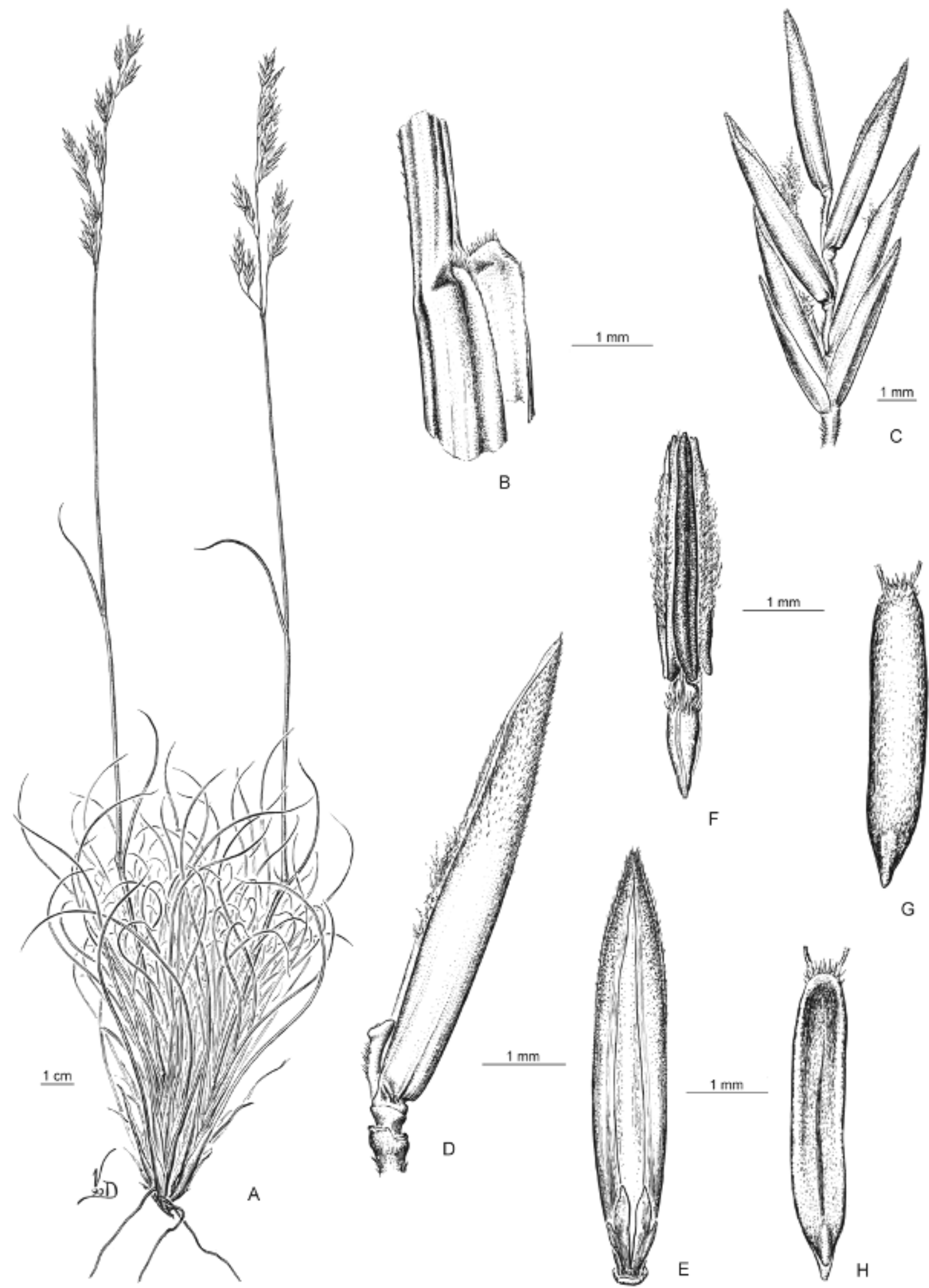

FIGURA 31. Festuca roigii. A. Hábito e inflorescencia. B. Zona ligular. C. Espiguilla. D. Antecio, vista lateral. E. Pálea, vista ventral con lodículas. F. Ápice ovario con anteras. G. Cariopsis, vista escutelar. H. Cariopsis, vista hilar. Reproducido de Catalán \& Müller (2012: 244). 

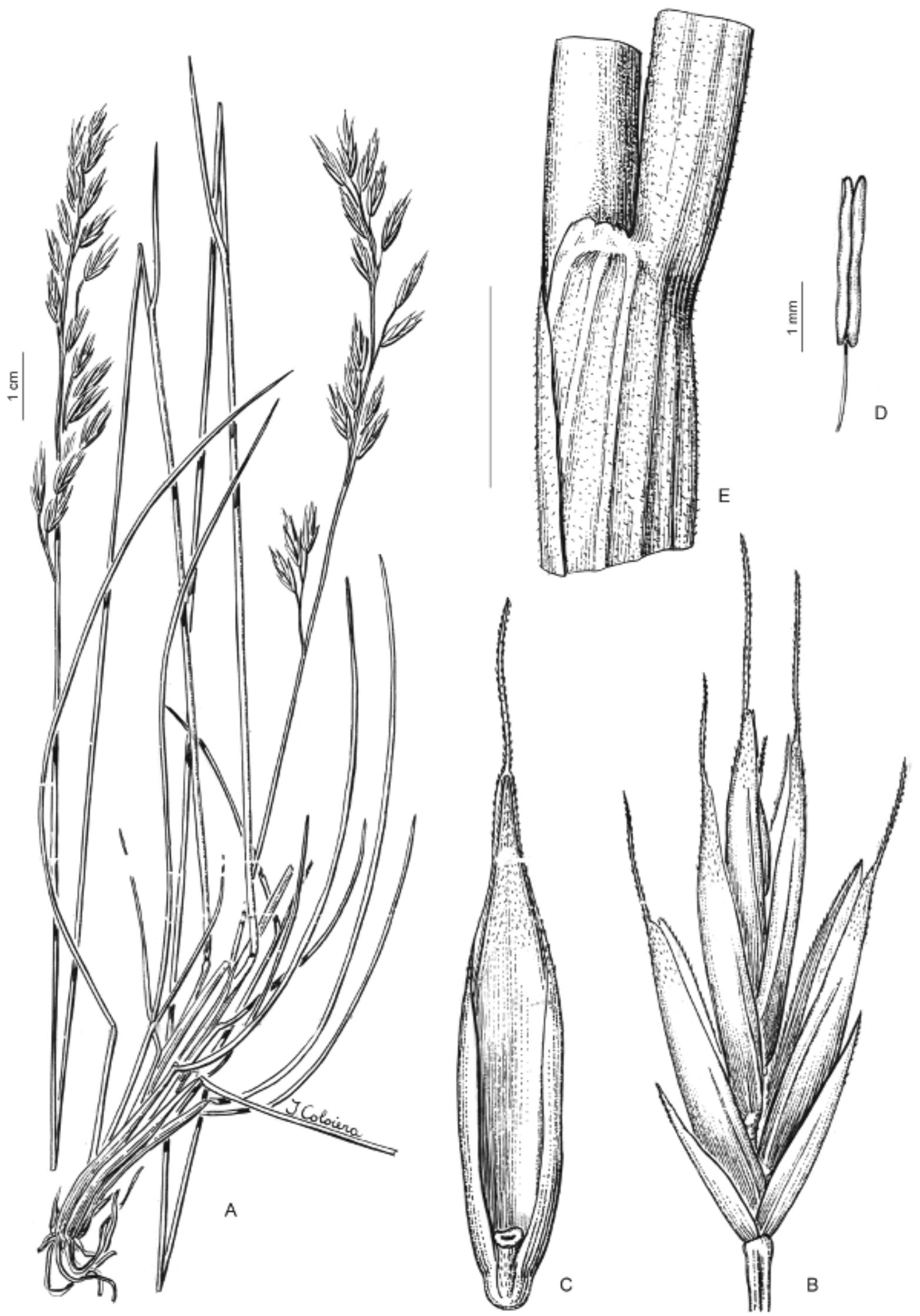

FIGURA 32. Festuca rubra. A. Hábito e inflorescencia. B. Espiguilla. C. Antecio, vista ventral. D. Antera. E. Zona ligular. Reproducido de Catalán \& Müller (2012: 245). 


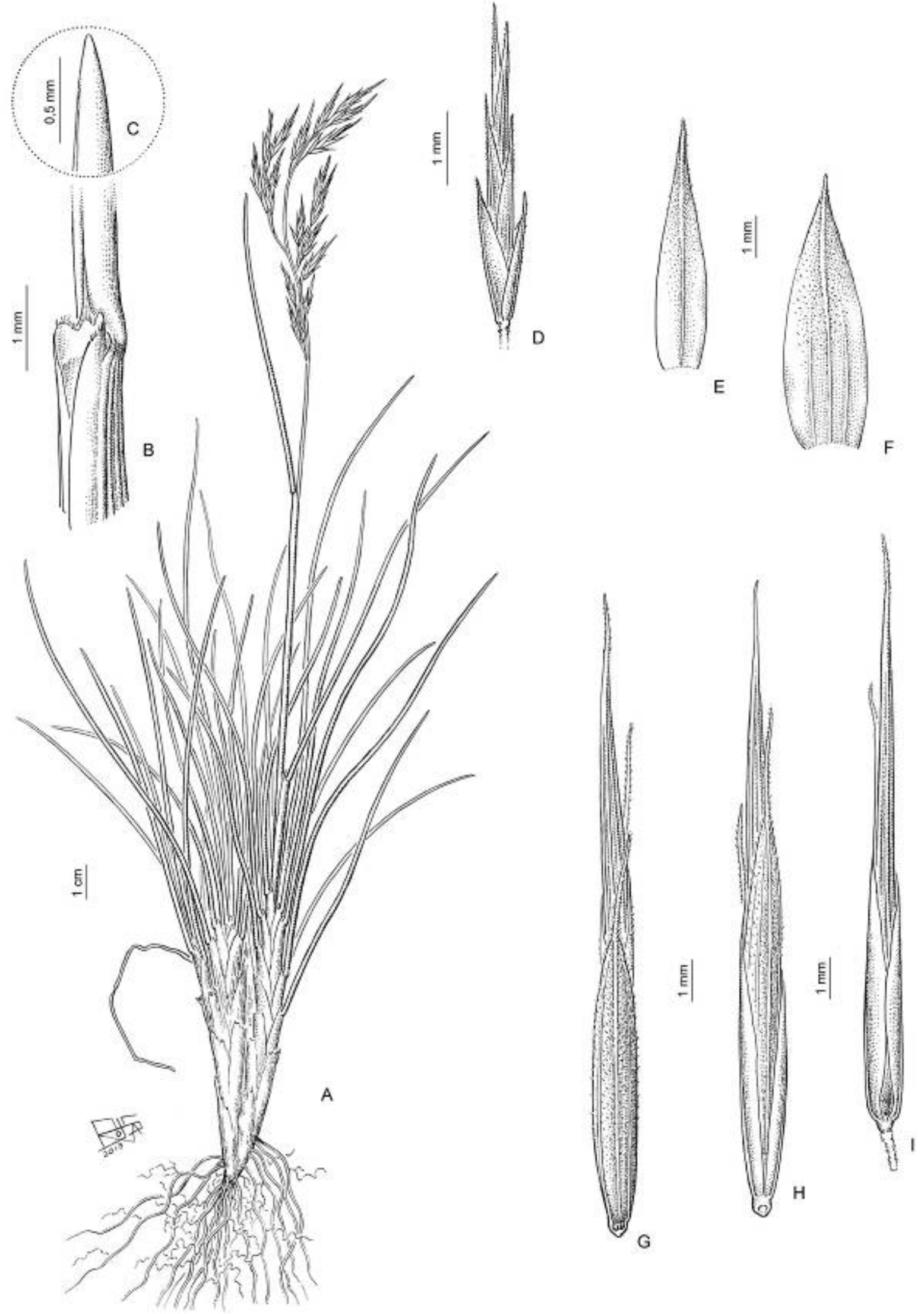

FIGURA 33. Festuca subantarctica. A. Hábito e inflorescencia. B. Zona ligular. C. Ápice de la lámina. D. Espiguilla. E. Gluma inferior, vista dorsal. F. Gluma superior, vista dorsal. G-I. Antecio proliferado (Boelcke et al. $866, \mathrm{SI})$. 


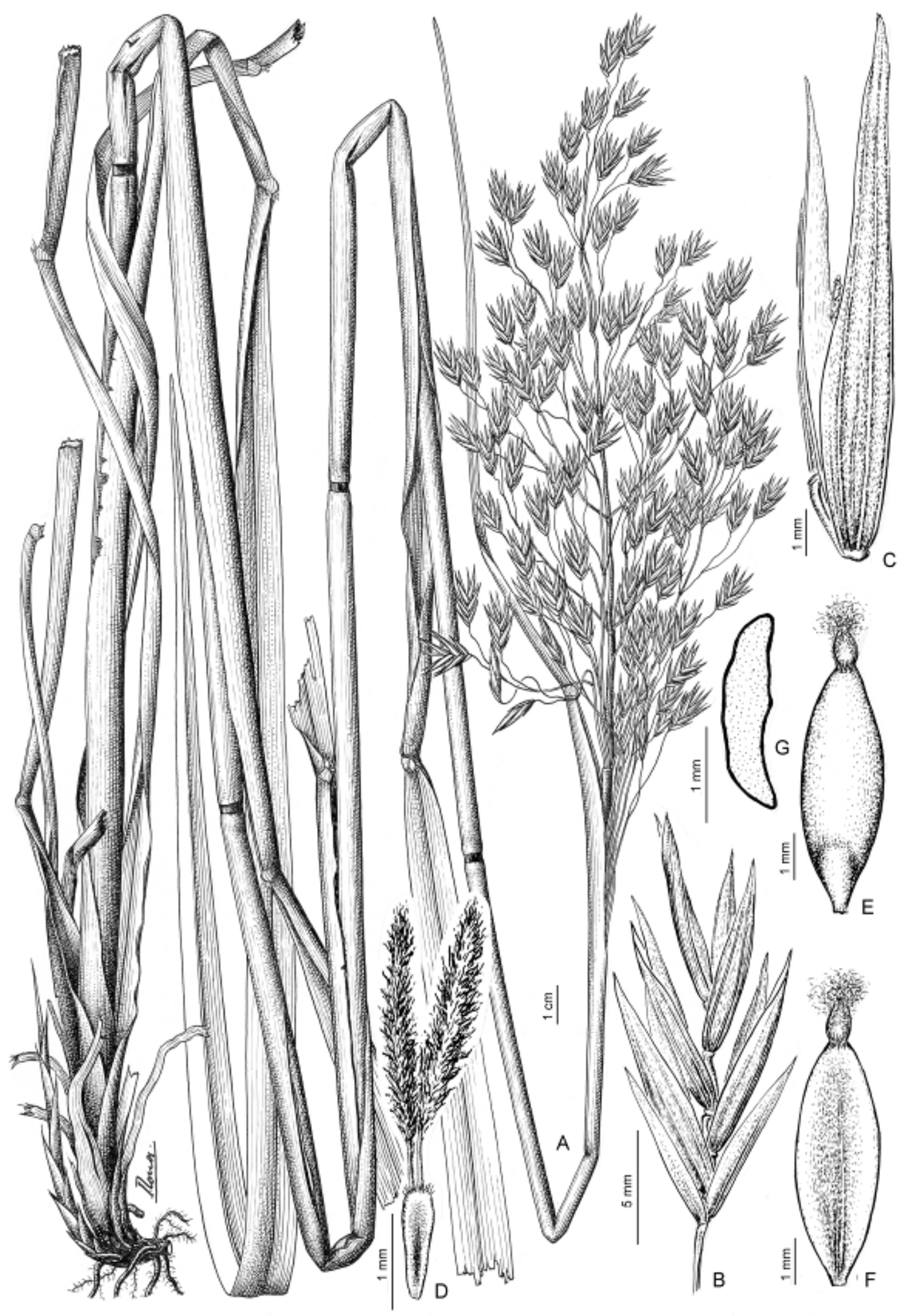

FIGURA 34. Festuca superba. A. Hábito e inflorescencia. B. Espiguilla. C. Antecio, vista lateral. D. Gineceo. E. Cariopsis, vista escutelar. F. Cariopsis, vista hilar. G. Cariopsis, en corte transversal. Reproducido de Catalán \& Müller (2012: 246). 


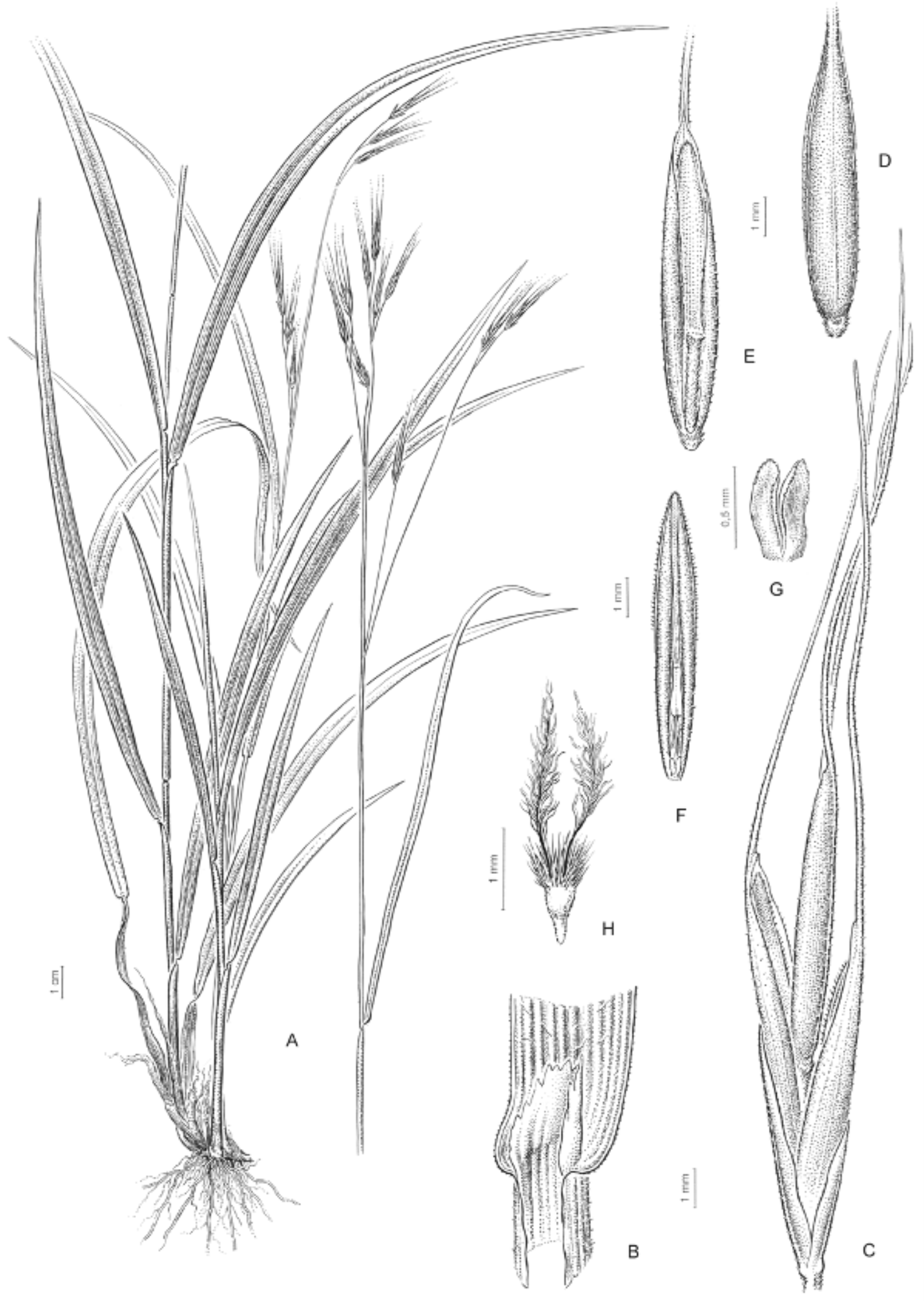

FIGURA 35. Festuca ulochaeta. A. Hábito e inflorescencia. B. Zona ligular. C. Espiguilla. D. Antecio, vista dorsal. E. Antecio, vista ventral. F. Pálea, vista ventral. G. Lodículas. H. Gineceo. Reproducido de Catalán \& Müller (2012: 248). 


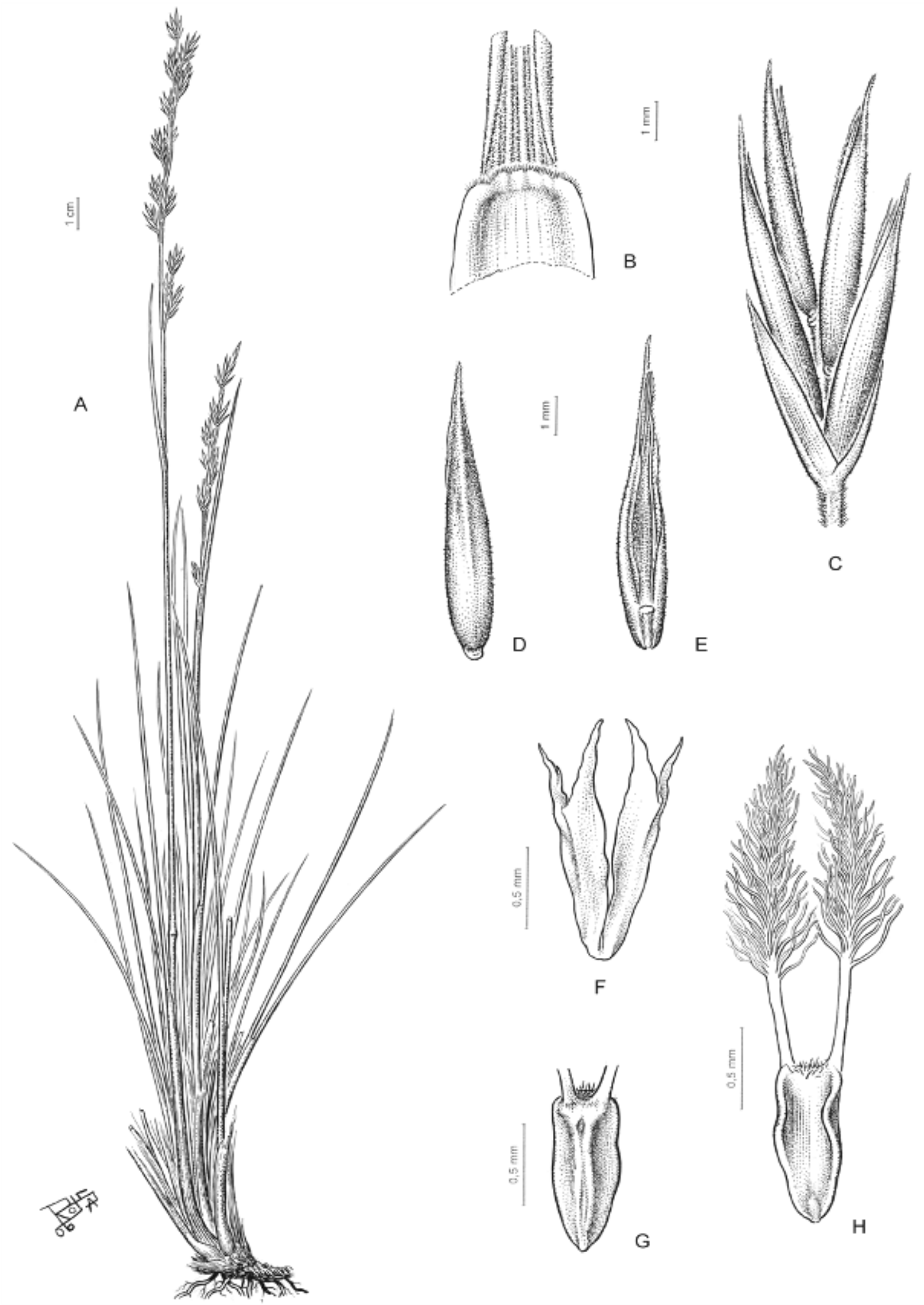

FIGURA 36. Festuca uninodis. A. Hábito e inflorescencia. B. Zona ligular. C. Espiguilla. D. Antecio, vista dorsal. E. Antecio, vista ventral. F. Lodículas. G. Cariopsis inmadura, vista escutelar y base de estilos. H. Cariopsis inmadura, vista hilar. Reproducido de Catalán \& Müller (2012: 248). 


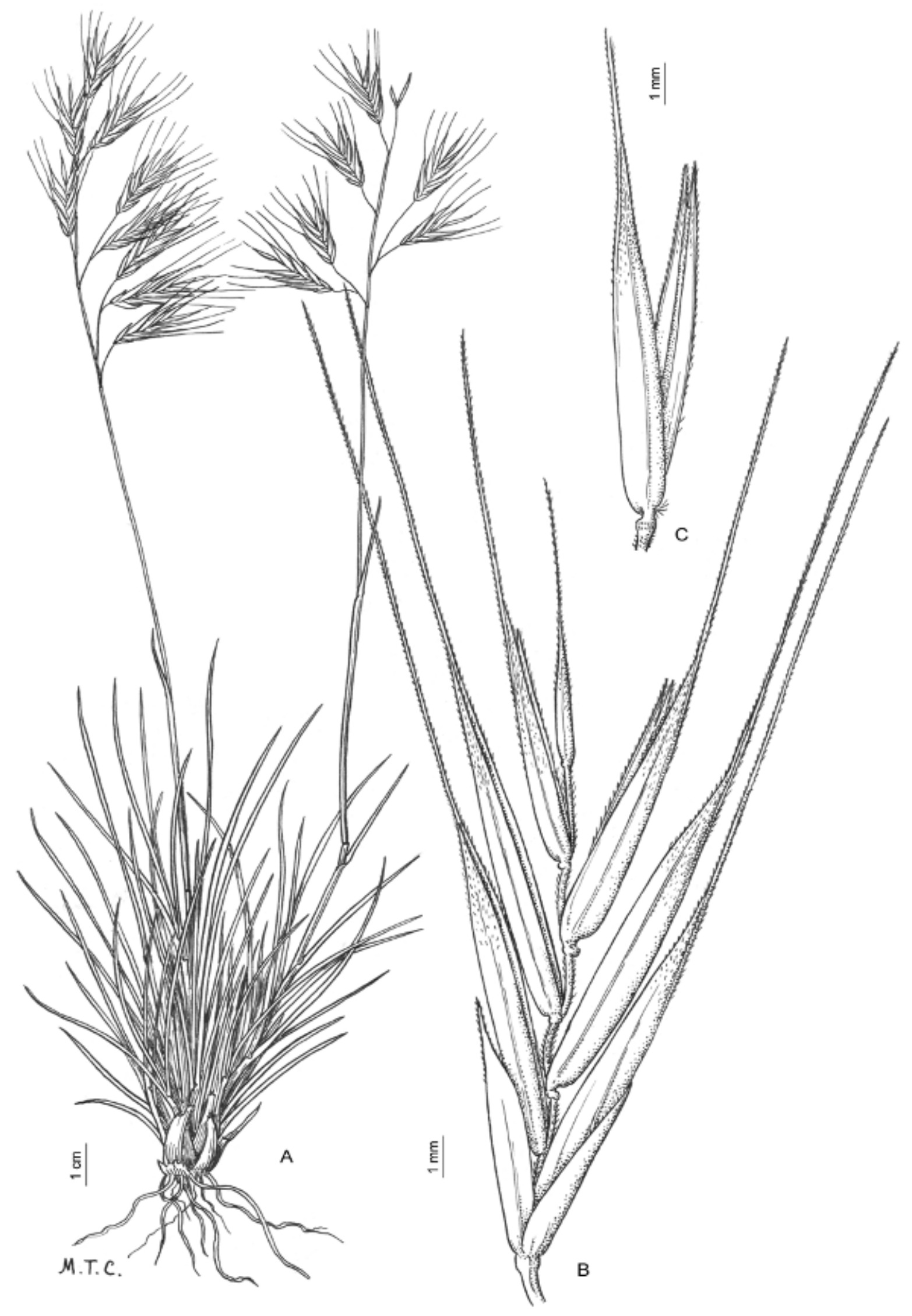

FIGURA 37. Festuca ventanicola. A. Hábito e inflorescencia. B. Espiguilla. C. Antecio, vista lateral. Reproducido de Catalán \& Müller (2012: 249). 


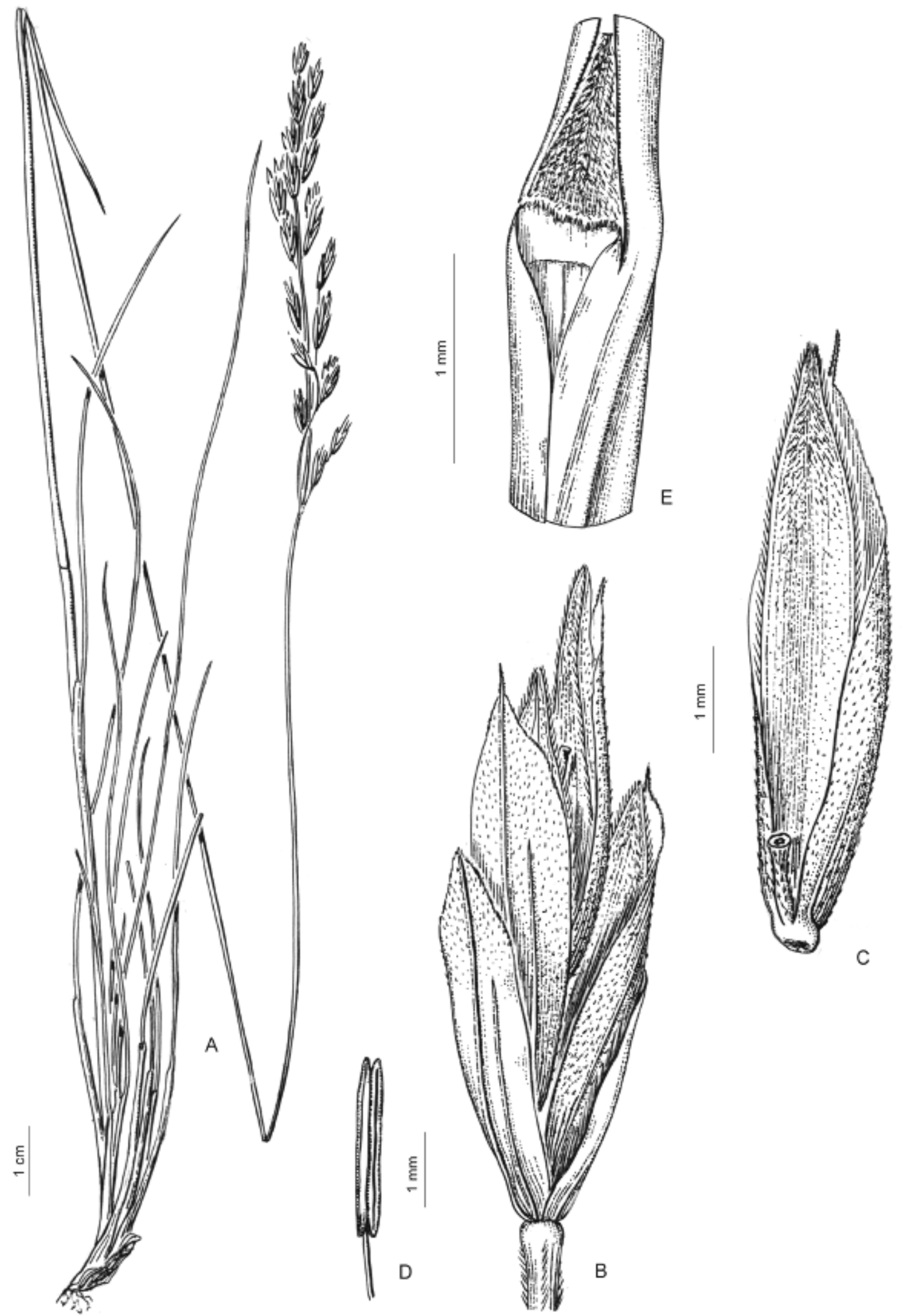

FIGURA 38. Festuca weberbaueri. A. Hábito e inflorescencia. B. Espiguilla. C. Antecio, vista ventral. D. Antera. E. Zona ligular. Reproducido de Catalán \& Müller (2012: 248). 

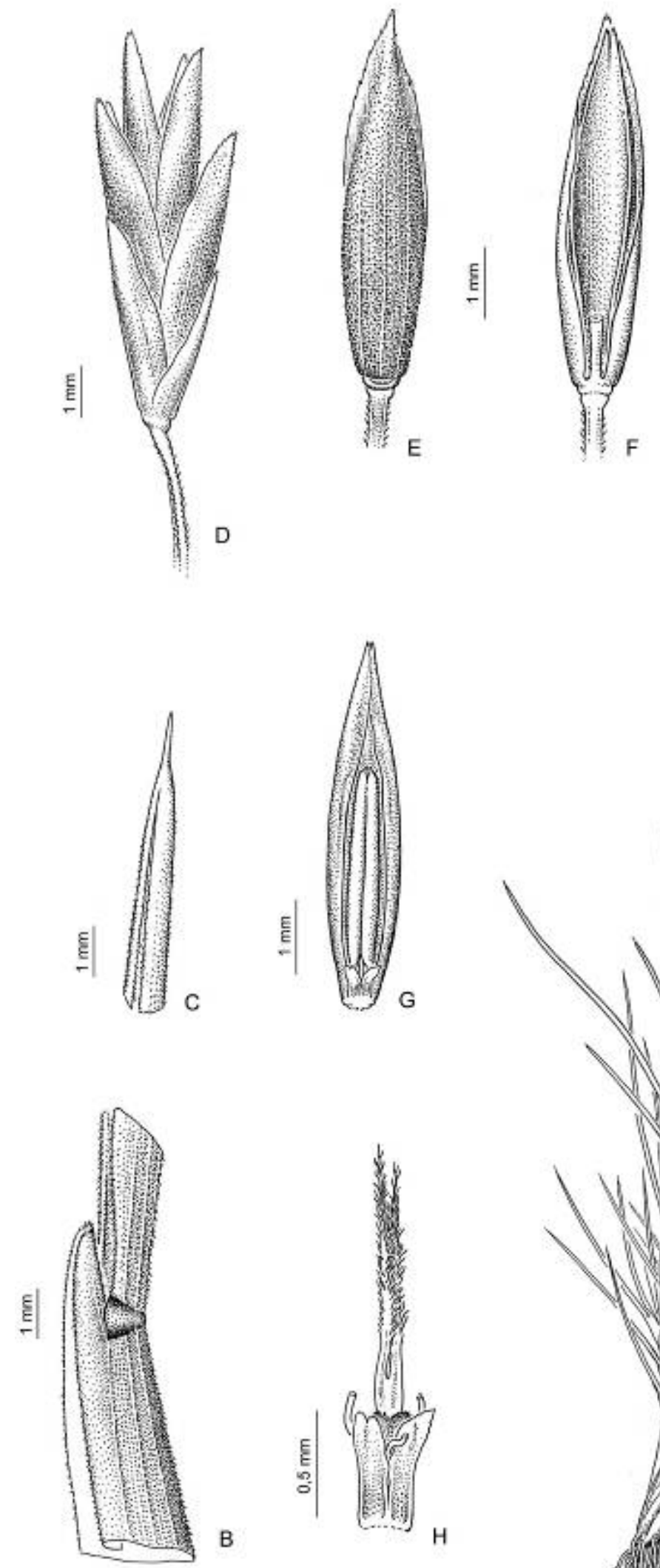

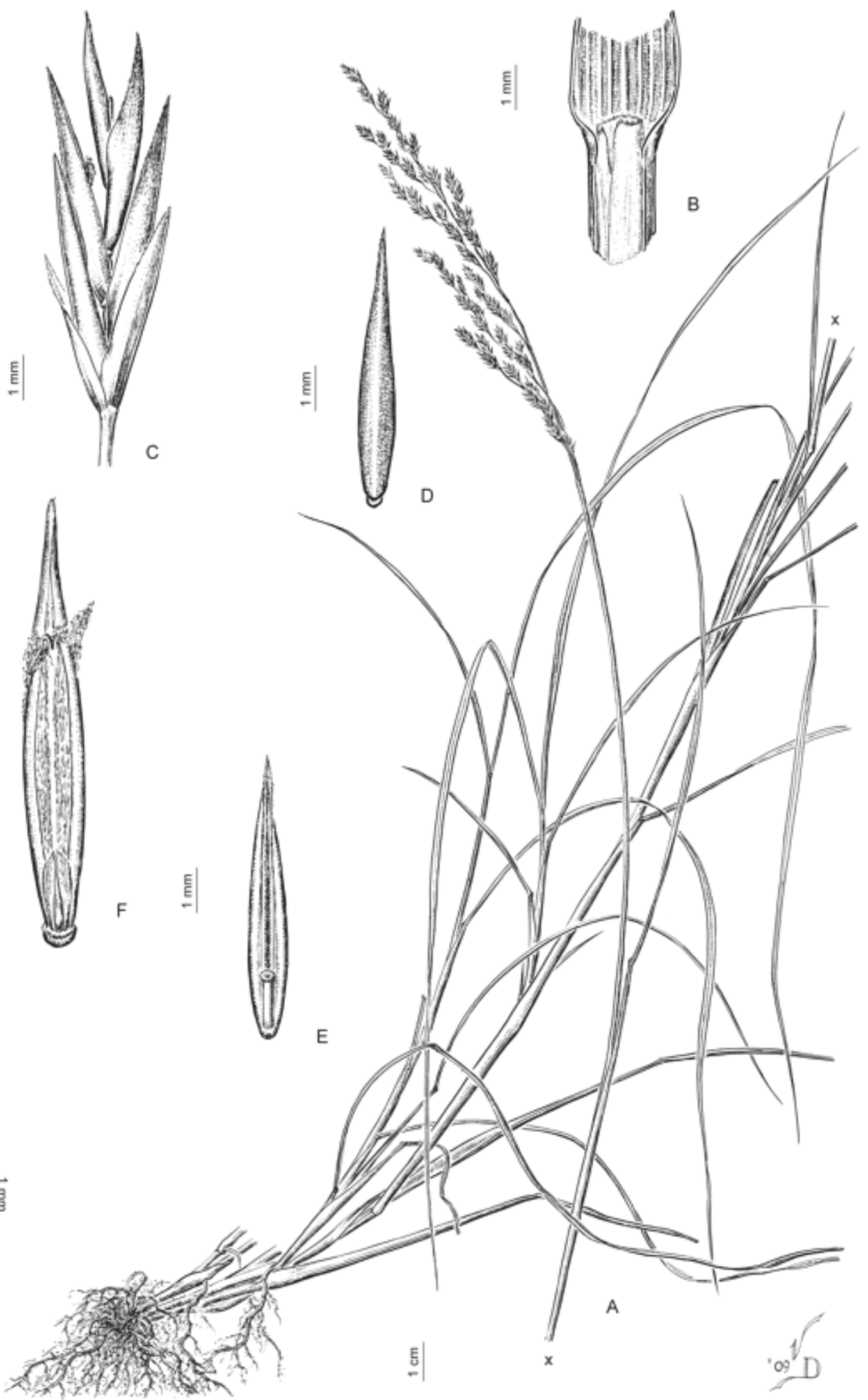

FIGURA 40. Festuca yalaensis. A. Hábito e inflorescencia. B. Zona ligular. C. Espiguilla. D. Antecio, vista dorsal. E. Antecio, vista ventral. F. Pálea, vista ventral. G. Cariopsis, vista escutelar. Modificado de Catalán \& Müller (2012: 250). 


\title{
CAPÍTULO IV
}

ANATOMÍA Y MICROMORFOLOGÍA FOLIAR DE LAS ESPECIES DE FESTUCA DEL CONO SUR

\begin{abstract}
ANTECEDENTES
La taxonomía de Festuca es altamente compleja debido al amplio rango de variabilidad intraespecífica; en muchos casos se dificulta establecer caracteres diagnósticos y existen distintos criterios para reconocer a un mismo taxón. Dado que los caracteres morfológicos no son siempre suficientes, las características de las hojas son relevantes a la hora de diferenciar especies. Sin embargo, ciertos caracteres foliares son difíciles de observar en los ejemplares de herbario, como por ejemplo el grado de pilosidad o enrollamiento de la lámina, o pueden ser dependientes de las condiciones ambientales, como el desarrollo del esclerénquima, o su escala de observación es muy pequeña, como ciertas estructuras epidérmicas.
\end{abstract}

La anatomía foliar de las especies del género Festuca ha sido utilizada durante más de un siglo como fuente alternativa de caracteres diagnósticos en estudios sistemáticos. Desde los trabajos pioneros se destacó la importancia de estos caracteres; la primera monografía de Festuca para Europa incluyó ilustraciones con las características anatómicas de 37 taxones (Hackel 1882).

Los caracteres anatómicos diagnósticos a nivel genérico fueron descriptos por Metcalfe (1960), quién incluyó observaciones sobre la epidermis abaxial, cortes transversales de las láminas y las cañas para varias especies de Festuca. Tzvelev (1976) proporcionó descripciones anatómicas para las especies de Rusia e hizo uso considerable de ellas como herramienta taxonómica para la sistemática del género. Markgraf-Dannenberg (1980) utilizó caracteres de la sección transversal de las láminas, como número de haces vasculares y distribución del tejido esclerenquimático, para la identificación de varias especies.

En relación a las especies del Nuevo Mundo, diversos autores realizaron estudios donde remarcaron la importancia de los caracteres anatómicos tanto para las especies de América del Norte (Alexeev 1982; Aiken \& Consaul 1995; Aiken et al. 1997) como para las especies de América del Sur. Específicamente, el primer tratamiento sobre las especies sudamericanas fue realizado por Saint-Yves (1927), quien incluyó en las descripciones datos sobre anatomía foliar. Las especies de Festuca de la zona de los Páramos en América del Sur fueron revisadas taxonómicamente por Stančík \& Peterson (2007) quienes consideraron caracteres anatómicos diagnósticos como el número de haces vasculares, la distribución del esclerénquima, la densidad 
relativa de la pubescencia y la longitud de los tricomas. Matthei (1982) presentó una clave para las especies chilenas de Festuca sobre la base de caracteres anatómicos en cortes transversales y epidermis abaxial en vista superficial, en la cual sólo tres especies, $F$. magensiana Potztal, $F$. magellanica Lam. y F. pyrogea Speg., no pueden diferenciarse. Asimismo, también se consideró la anatomía foliar para las especies de Argentina (Parodi 1953; Türpe 1969, Catalán \& Müller 2012) y de Bolivia (Renvoize 1998).

En la mayoría de los trabajos citados, los caracteres anatómicos foliares que se utilizaron para diferenciar especies son la posición y desarrollo del esclerénquima, la diferenciación de células buliformes, el número de haces vasculares, la diferenciación de surcos y costillas, y la presencia de anexos epidérmicos como macropelos y asperezas. La mayoría de estos caracteres se utilizan para diferenciar principalmente las especies de hoja fina que son más difíciles de identificar; sin embargo, cuando estos caracteres son analizados en numerosos especímenes puede que su significancia decline (Aiken et al. 1985; Aiken \& Counsal 1995). En algunos trabajos se ha demostrado que varios de estos caracteres pueden presentar cierta plasticidad en relación a las condiciones ambientales (Kjellqvist 1961; Dubé \& Morissete 1996). En particular, la disposición del esclerénquima asociada a los haces vasculares reviste interés ya que puede presentar diferentes patrones: formando casquetes individuales, o un anillo abaxial continuo o trabas que se extienden desde una epidermis hasta la otra. Dubcovsky \& Martínez (1988) concluyeron que la disposición del esclerénquima formando trabas es menos variable a nivel intraespecífico que el esclerénquima formando un anillo abaxial continuo; por ello consideran que los caracteres anatómicos solamente no son suficientes para sumariar la variación entre las especies de Festuca.

Los caracteres foliares epidérmicos en vista superficial también han sido considerados de importancia en Festuca, tanto observados bajo microscopía óptica o, más modernamente, con microscopía electrónica de barrido. Estructuras como estomas, macropelos, cuerpos silíceos, disposición de células largas y células cortas revisten cierto valor diagnóstico para el género (Aiken \& Lefkovitch 1984, Markgraf-Dannenberg 1980, Namaganda et al. 2009, Connor 1960, Badoux 1971, Aiken \& Darbyshire 1990, Aiken et al. 1994, Aiken \& Consaul 1995, Ortúñez \& de la Fuente 2010, Zarinkamar \& Jouyandeh 2011).

Otros patrones observados con microscopía electrónica de barrido, como disposición de ceras epicuticulares fueron menos explorados. Se ha observado en diferentes especies de Festuca que las ceras epicuticulares pueden presentarse formando capas más o menos densas y continuas de espesor variable, mientras que en otras las ceras pueden formar cristaloides granulosos, en hebras, en plaquetas, etc. (Ortuñez \& de la Fuente 2010, Ortuñez \& Cano-Ruiz 2013). 
La mayoría de los estudios filogenéticos sostienen que Festuca, según su circunscripción tradicional, representa un grupo no natural de especies y, además, se ensambla con especies de otros géneros como Lolium L., Vulpia C.C. Gmel., etc. (Catalán et al. 2004, Catalán 2006, Inda et al. 2008, Soreng et al. 2015). Dentro de este esquema evolutivo pueden distinguirse dos linajes diferentes: las especies de "hojas anchas" que serían linajes más basales, y las especies de "hoja fina" que representarían linajes más recientes.

Catalán (2006) presenta un esquema evolutivo donde combina caracteres morfológicos con tipos de láminas foliares para diferentes subgéneros y secciones de Festuca. Dentro de este esquema Catalán (2006) observa que el linaje "hoja ancha" incluye especies de láminas planas, con plegamientos convolutos a supervolutos, esclerénquima dispuesto en trabéculas, innovaciones extravaginales y presencia de catafilos. Por otro lado, el linaje "hoja fina" se caracteriza por incluir especies con láminas finas, plegamientos conduplicados, esclerénquima no dispuesto en trabéculas, innovaciones intravaginales y catafilos generalmente ausentes. De esta manera, la forma "hoja ancha" podría ser plesiomórfica, de la cual habrían evolucionado las formas "hoja fina" (Catalán 2006); sin embargo, la falta de resolución en las ramas basales de los árboles filogenéticos y la presencia de clados intermedios a los dos linajes mayores, hacen que esta hipótesis sea algo dudosa (Catalán et al. 2004).

A pesar del amplio uso en los trabajos taxonómicos y filogenéticos sobre Festuca de los términos "hoja fina" y "hoja ancha", hasta la fecha éstos no se han definido con precisión y, en la práctica, solamente se aplican según la característica más obvia que es el ancho de la lámina. Namaganda \& Lye (2008) detectaron que el término "hoja fina" incluye aquellas especies con láminas de forma acicular, setáceo, en forma de cilindro o filiformes. Por otro lado Clayton \& Renvoize (1986) señalan que las láminas foliares en las especies de "hoja ancha" incluyen plantas con hojas planas o dobladas, pero esto puede ser engañoso, principalmente cuando se trata de ejemplares de herbario.

Por ello, los términos "hoja ancha" y "hoja fina" podrían estar representando un síndrome o patrón que incluya más diversidad de caracteres, para lo cual es necesario evaluar la estructura foliar con estudios más detallados de anatomía y micromorfología, intentando establecer patrones foliares que contribuyan a la identificación de las especies, y que a su vez puedan ser evaluados de manera más precisa dentro de un contexto filogenético.

El objetivo general del presente capítulo es contribuir al conocimiento de la anatomía y micromorfología foliar de las especies de Festuca que se distribuyen en el Cono Sur, a través de un estudio detallado y comparativo. Se pretende analizar la relevancia de los caracteres anatómicos y micromorfológicos, y reconocer tipos foliares que puedan caracterizar a las 
especies de Festuca del Cono Sur para una mejor identificación. Asimismo, se revisan desde el aspecto anatómico y micromorfológico, los términos "hoja fina" y "hoja ancha" utilizados frecuentemente en estudios taxonómicos y filogenéticos. Por último, se comparan los patrones foliares con los rangos de distribución altitudinal de las especies de Festuca del Cono Sur.

\section{MATERIALES Y MÉTODOS}

\section{$\underline{\text { Revisión bibliográfica }}$}

Se realizó una revisión exhaustiva del material bibliográfico relacionado con la anatomía y micromorfología de la familia Poaceae (Prat 1932, 1948; Metcalfe 1960; Reeder \& Ellington 1960; De Lisle 1963; Parry \& Smithson 1964; Stace 1965; Jozwik 1969; Ellis 1976, 1979; Tomaszewski \& Zielinski 2014) y especialmente del género Festuca se revisaron estudios de anatomía comparada y tratamientos taxonómicos que utilizan dichos caracteres (GarcíaGonzález 1983; Dubcovsky \& Martínez 1988; Aiken \& Consaul 1995; Stančík 2003; Stančík \& Peterson 2007; Darbyshire \& Pavlick 2007; Ortuñez \& de la Fuente 2010; Ortuñez \& CanoRuiz 2013; Dani et al. 2014). Se estudiaron las descripciones anatómicas proporcionadas en los trabajos que corresponden a los taxones presentes en el Cono Sur.

\section{Material vegetal estudiado}

Para los estudios anatómicos y micromorfológicos se realizaron observaciones mediante el uso de microscopia óptica y microscopia electrónica de barrido, respectivamente, para todas las especies que crecen en el área de estudio, el Cono Sur de América.

Los materiales analizados proceden de ejemplares herborizados y depositados en los siguientes herbarios: BA, BAB, COL, CONC, CORD, CUZ, HUA, HSB, HUSA, LIL, LP, LPB, MOL, QCNE, QPLS, SGO, SI, USM y VEN, abreviados según Thiers et al. (2015). Además, se obtuvieron muestras frescas fijadas en FAA provenientes de diferentes viajes de colección realizados en Chile y Argentina. Los ejemplares de herbario de los cuales procede el material estudiado se encuentran señalados con un asterisco después del acrónimo del herbario, en el material estudiado que se muestra en el Apéndice I (Material de herbario estudiado). 
Para documentar los caracteres anatómicos y micromorfológicos, y con el objeto de que las observaciones fuesen comparables, se estandarizó la zona de observación. Se seleccionó una hoja desarrollada perteneciente a una innovación estéril, de la cual se obtuvieron fragmentos de del tercio medio de la lámina, de $1 \mathrm{~cm}$ de longitud para realizar los cortes transversales y dos fragmentos de $4 \times 4 \mathrm{~mm}$ para la observación de epidermis adaxial y abaxial con microscopía electrónica de barrido. Por otro lado, para detectar la posible variación intraespecífica que pudieran presentar los caracteres, se seleccionaron de 7-15 especímenes por cada especie, dependiendo de la disponibilidad de los ejemplares y del rango de distribución geográfica de cada especie.

Adicionalmente, se estudió la anatomía y micromorfología foliar de las epecies $F$. vaginalis (Benth.) Lægaard, F. chimborazensis E.B. Alexeev, F. asplundii E.B. Alexeev, F. caspaltensis Ball, F. cochabambana E.B. Alexeev, F. dolichophylla J. Presl y F. cuzcoensis Stančík \& P.M. Peterson, que si bien se distribuyen por América del Sur, crecen fuera del área de estudio de la presente tesis. Dichas especies se seleccionaron porque se relacionan filogenéticamente con las especies del Cono Sur, y fue necesario incluirlas con el objeto de comparar la anatomía foliar dentro de un contexto evolutivo. Los ejemplares de dichas especies se incluyen en el Apéndice.

Exploración y registro de los atributos anatómicos vistos al microscopio óptico (MO)

Los fragmentos provenientes de material de herbario fueron hidratados en agua destilada y detergente común [1:3] a $70{ }^{\circ} \mathrm{C}$ de temperatura, durante 24 horas. Posteriormente, el fragmento fue lavado con agua destilada y fijado en GALA (Glicerina, Alcohol y Ácido Acético) durante 12 horas.

Se realizaron cortes a mano alzada, siguiendo la metodología propuesta por Metcalfe (1960). Los cortes a mano alzada fueron sumergidos en hipoclorito de sodio al 60\%, durante el tiempo necesario hasta que el tejido tomó aspecto transparente (eliminando el contenido celular), luego, los cortes fueron lavados mediante sucesivos pasajes por agua destilada durante 20 minutos para eliminar los residuos de hipoclorito. A continuación se tiñeron mediante Safranina en solución acuosa (colorante de contraste) durante 3-4 minutos y se lavaron por última vez en agua, para ser montados en medio de montaje semipermanente gelatina-glicerinada (Ruzhin 1993).

En algunos casos, se realizaron cortes con micrótomo rotatorio, previa inclusión en parafina siguiendo los métodos sugeridos por Ruzhin (1993). Dada la presencia de cuerpos silíceos en la epidermis que dificultan la obtención de cortes enteros, los materiales fueron previamente desilicificados mediante la utilización de ácido fluorhídrico al 10\% durante 24 hs. Después se 
siguió una serie ascendente de alcoholes, xilol, finalizando con la inclusión del material en parafina. En este caso, los cortes se tiñeron con doble coloración Safranina-Fast green en solución alcohólica (Ruzhin 1993).

También se realizaron preparados epidérmicos según la técnica propuesta por Metcalfe (1960), la cual consiste básicamente en eliminar la superficie opuesta a la que se desea observar por raspado y clarificación con solución de hipoclorito de sodio. Mediante este proceso se obtuvieron preparados de epidermis adaxial y abaxial para cada espécimen, los que se tiñeron con Safranina en solución acuosa y también se montaron en gelatina-glicerinada.

La observación de los cortes anatómicos, preparados epidérmicos y el registro fotográfico de los mismos se realizó bajo un Nikon SMZ 800 microscópico y cámara fotográfica Nikon con software NIS elements. Las descripciones de los caracteres histofoliares de las especies estudiadas, siguen la terminología propuesta por Ellis $(1976,1979)$.

Exploración y registro de los atributos micromorfológicos vistos con microscopio electrónico de barrido (MEB)

Para explorar caracteres epidérmicos de la lámina con fino detalle, tales como ceras epicuticulares, células silíceas y ornamentación de las paredes celulares se utilizaron dos fragmentos de $4 \times 4 \mathrm{~mm}$ seleccionados del tercio medio de la lámina, que fueron recubiertos con oro-paladio al 40-60\% y se examinaron en un microscopio electrónico de barrido (MEB). La observación y el registro fotográfico se realizaron bajo un Phillips-XL Serie 30. La descripción de los caracteres micromorfológicos sigue la terminología propuesta por Ellis (1979) y Ortúñez \& de la Fuente (2010); y Ortúñez \& Cano-Ruiz (2013).

\section{Análisis numérico}

Se llevó a cabo un análisis estadístico multivariado con caracteres anatómicos y micromorfológicos para todas las especies que crecen en el Cono Sur de América, tratando de establecer semejanzas entre las especies que permitan definir diferentes patrones foliares. Esto se realizó mediante un análisis de conglomerados con el algoritmo UPGMA (unweighted pairgroup method using an arithmetic average), utilizando el coeficiente de distancia de Manhattan mediante el programa NTSYS $2.02 \mathrm{i}$ (Rohlf, 1998). 
A partir de las observaciones con MO y MEB se definieron 35 caracteres, con su correspondiente codificación, que se listan a continuación:

ANATÓMICOS - Forma del transcorte, (0) en U; (1) en V; (2) plano. Tipo de plegamiento, (0) conduplicado; (1) expandido, a veces algo convoluto o involuto. *Número total haces de haces vasculares. Diferenciación entre haces menores (secundarios y terciarios) y haces de primer orden, (0) ausentes; (1) presentes. Costillas adaxiales, (0) inconspicuas a poco profundas; (1) desarrolladas. Diferenciación de costilla central, (0) ausente; (1) presente. Superficie abaxial, (0) lisa; (1) irregular; (2) con costillas desarrolladas. Trabas esclerenquimáticas adaxiales, (0) ausente; (1) presente. Trabas esclerenquimáticas abaxiales, (0) ausente; (1) presente. Casquetes esclerenquimáticos adaxiales, (0) ausente; (1) presente. Casquetes esclerenquimáticos abaxiales, (0) ausente; (1) presente. Anillo abaxial esclerenquimático contínuo, (0) ausente; (1) presente. Células buliformes, (0) indiferenciadas; (1) diferenciadas. Forma de las células buliformes, (0) redondeadas; (1) en forma de abanico. Pared tangencial externa de células epidérmicas adaxiales, (0) planas; (1) convexas; (2) papilosas. *Pared tangencial externa de células epidérmicas abaxiales, (0) planas; (1) convexas; (2) papilosas.

MICROMORFOLÓGICOS-Diferenciación de las zonas costales e intercostales en epidermis abaxial, (0) homogéneo; (1) heterogéneo. *Macropelos en epidermis abaxial (0) ausente; (1) presente. Estomas en epidermis abaxial, (0) ausente; (1) presente. Asperezas en epidermis abaxial, (0) ausente; (1) presente. Tipo de cuerpo silíceo en epidermis abaxial, (0) no distinguible; (1) redondeado; (2) cuadrangular; (3) elíptico. Ceras epicuticulares en epidermis abaxial, (0) continuas; (1) en cristaloides. Pares sílico-suberosos en epidermis abaxial, (0) ausente; (1) presente. *Células largas en zona costal de epidermis abaxial, (0) cuadrada; (1) rectangular [2 a 5 veces ancho/largo]; (2) elongada [más de 5 veces ancho/largo]; (3) fusiforme. Paredes anticlinales de células largas en zona costal de epidermis abaxial, (0) lisa; (1) sinuosa; (2) ondulada en U; (3) muy ondulada en $\Omega$. *Diferenciación de las zonas costales e intercostales en epidermis adaxial, (0) homogéneo; (1) heterogéneo. Macropelos en epidermis adaxial (0) ausente; (1) presente. *Estomas en epidermis adaxial, (0) ausente; (1) presente. Asperezas en epidermis adaxial, (0) ausente; (1) presente. Tipo de cuerpo silíceo en epidermis adaxial, (0) no distinguible; (1) redondeado; (2) cuadrangular; (3) elíptico. Ceras epicuticulares en epidermis adaxial, (0) continuas; (1) en cristaloides. *Pares sílico-suberosos en epidermis adaxial, (0) ausente; (1) presente. Células largas en zona costal de epidermis adaxial, (0) cuadrada; (1) rectangular [2 a 5 veces ancho/largo]; (2) elongada [más de 5 veces ancho/largo]; (3) fusiforme. Paredes anticlinales de células largas en zona costal de epidermis adaxial, (0) lisa; (1) sinuosa; (2) ondulada en U; (3) muy ondulada en $\Omega$. 
Luego se seleccionaron sólo aquellos caracteres que resultaron constantes a nivel específico y permitieron atribuirle un único estado para cada especie, y también se descartaron los caracteres no informativos por ser invariables entre los taxones analizados. Dichos caracteres se indican con asterisco en los párrafos anteriores. De esta manera, se definen 28 caracteres (15 anatómicos y 13 micromorfológicos) y con ellos se construyó una matriz para 43 taxones (41 especies y dos variedades) de Festuca del Cono Sur.

\section{$\underline{\text { Relación entre la estructura foliar y la distribución altitudinal }}$}

Se analizó la estructura anatómica y micromorfológica de las láminas para las especies de Festuca del Cono Sur en función del rango altitudinal donde crecen los diferentes taxones. Para ello se comparó el tipo foliar de cada especie en función de los límites altitudinales mínimo y máximo. Dichos valores provienen de la información presentada en el Capítulo III. Tratamiento taxonómico de las especies de Festuca del Cono Sur.

\section{RESULTADOS}

\section{Caracterización general de la anatomía foliar en corte transversal}

Las especies de Festuca del Cono Sur mostraron diferencias significativas en los atributos anatómicos de sus láminas foliares, los cuales se describen a continuación:

- Forma del transcorte foliar

Se observan dos tipos principales de transcortes foliares: especies con láminas abiertas o expandidas y especies con láminas plegadas. Las láminas abiertas o expandidas son generalmente planas, aunque en algunos casos pueden enrollarse temporalmente de manera convoluta o involuta. Dentro de la especies de Festuca del Cono Sur presentan láminas abiertas o expandidas: F. arundinacea Schreb., F. fimbriata Nees, F. hieronymi Hack., F. nemoralis Türpe, F. parodiana (St.-Yves) Nicora, F. purpurascens Banks et Sol. ex Hook. f., F. superba Parodi ex Türpe y F. ulochaeta Nees ex Steud..

Por otro lado, las especies con transcortes plegados se pliegan de manera conduplicada (lámina plegada en dos a lo largo del nervio medio). Dentro de este grupo pueden diferenciarse cortes foliares en forma de "V" (en F. contracta Kirk., F. gracillima var. gracillima Hook. f., F. 
gracillima var. glacialis Rúgolo \& Nicora, F. lilloi Hack., F. magellanica Lam., F. pallescens (St.-Yves) Parodi, F. panda Swallen, F. pyrogea Speg., F. roigii Dubcovs. \& Rúgolo, F. rubra L. y $F$. werdermannii St.-Yves, o transcortes permanentemente plegados en forma de "U" (en $F$. acanthophylla var. acanthophylla É. Desv., F. acanthophylla var. scabriuscula J.C. Ospina, Aliscioni, S. Denham, F. argentina (Speg.) Parodi, F. argentinensis (St.-Yves) Türpe, F. castilloniana Türpe, F. chrysophylla Phil., F. cirrosa (Speg.) Parodi, F. dissitiflora Steud. ex Griseb., F. distichovaginata Pilg., F. fiebrigii Pilg., F. hypsophila Phil., F. kurtziana St.-Yves, F. lasiorrhachis Pilg., F. monticola Phil., F. nardifolia Griseb., F. ovina subsp. tenuifolia (Sibht.) Celak., F. pampeana Speg., F. parodii St.-Yves, F. rigescens (J. Presl) Kunth, F. subantarctica Parodi, F. uninodis Hack., F. ventanicola Speg., F. yalaensis Joch.Müll. \& Catalán y $F$. weberbaueri Pilg.). En la mayoría de los casos de láminas plegadas, conduplicadas, la forma del transcorte resulta constante a nivel específico, con pocas excepciones ( $F$. kurtziana, $F$. magellanica, $F$. pallescens, $F$. pyrogea, $F$. rigescens, $F$. yalaensis) donde se observa cierta variabilidad a nivel intraespecíficos, aunque siempre con un tipo predominante.

- Diferenciación entre surcos y costillas

Las superficies foliares adaxiales de todas las especies estudiadas presentan diferenciación entre zonas costales (costillas) y zonas intercostales (surcos); generalmente esta diferenciación es muy pronunciada o algo más atenuada (como en $F$. arundinacea, $F$. parodiana, $F$. superba y $F$. ulochaeta). En cuanto a la forma de las costillas, es un atributo algo variable, incluso dentro de un mismo individuo. En especies como $F$. arundinacea, $F$. fimbriata, $F$. nemoralis, $F$. parodiana, F. parodii, F. purpurascens, $F$. superba, F. ulochaeta y $F$. yalaensis, las costillas se presentan mayoritariamente de redondeadas a cuadrangulares. Mientras que, en $F$. acanthophylla var. acanthophylla, F. acanthophylla var. scabriuscula, F. chrysophylla, F. cirrosa, F. distichovaginata, F. lasiorrhachis, F. magellanica, F. monticola, F. pyrogea, F. rigescens, $F$. subantarctica, $F$. pampeana, $F$. ventanicola y $F$. werdermannii, generalmente son más triangulares aunque también pueden ser cuadrangulares.

La superficie abaxial puede presentar diferenciación entre surcos y costillas pero en menor grado que la superficie adaxial como por ejemplo en $F$. ulochaeta y $F$. purpurascens, o pueden ser completamente lisas, sin surcos ni costillas como por ejemplo en $F$. monticola, $F$. acanthophylla var. acanthophylla, etc. Otras especies como $F$. argentina, $F$. argentinensis, $F$. hypsophila, F. kurtziana, F. pallescens, F. rubra y otras, presentan una superficie abaxial irregularmente ondulada, pero no desarrollan costillas y surcos. 
Por otro lado, las especies de Festuca con láminas expandidas pueden presentar una costilla central desarrollada con parénquima incoloro, con uno a varios haces vasculares asociados, como se observa por ejemplo en $F$. superba y $F$. ulochaeta.

- Número y desarrollo de haces vasculares

Los haces vasculares de primer orden se caracterizan por presentar elementos de vaso desarrollados en el metaxilema; en la mayoría de las especies aquí estudiadas estos haces se distinguen claramente de los haces menores. Sin embargo, en algunas pocas especies como por ejemplo F. magellanica, F. pallescens, F. pyrogea y F. rubra, los haces de menor tamaño también pueden tener elementos de vaso algo diferenciados, por lo cual no es muy clara la distinción entre estos dos tipo de haces. En cuanto al número total de haces vasculares, se observa un amplio rango de variación, incluso a nivel intraespecífico, más notorio en las especies de Festuca con lámina expandida, donde el número de haces varía entre 20 y 45 . Por otro lado, las especies con láminas plegadas resultaron más constantes en este aspecto, presentando generalmente 3-15 haces vasculares (pero hasta 25 en F. lasiorrhachis).

\section{- Tejido esclerenquimático}

La presencia y el grado de desarrollo del esclerénquima fue uno de los caracteres más utilizados tradicionalmente para diferenciar especies de Festuca. En las especies del Cono Sur, este tejido se presenta de manera muy diversa y con diferentes grados de desarrollo. Por ejemplo, el esclerénquima relacionado a los haces vasculares puede presentarse en forma de casquetes solo abaxiales (p. ej. F. pampeana), o abaxiales y adaxiales (p. ej. F. roigii); también el esclerénquima puede formar trabas abaxiales (p. ej. F. lilloi) o abaxiales y adaxiales (p. ej. $F$. argentina) cuando desarrolla más profundamente hasta hacer contacto con la vaina del haz. En casos más extremos, el esclerénquima se desarrolla en forma de banda o anillo abaxial completo, es decir, se dispone en capas continuas de células contiguas a la epidermis abaxial (p. ej. F. acanthophylla). Aunque existe cierta variación en el desarrollo del esclerénquima, el patrón general dentro de una especie es usualmente constante, lo cual hace que este carácter tenga un cierto grado de utilidad en la identificación de las especies.

- Epidermis adaxial y abaxial en corte transversal

Los caracteres de las células epidérmicas que pueden observarse en corte transversal de la lámina son: la forma de la pared tangencial externa, la cual se presenta plana o arqueada, en algunos casos formando papilas (como en la epidermis adaxial de $F$. monticola). También se puede observar la presencia de células buliformes, las cuales se presentan muy desarrolladas en las especies con láminas abiertas, generalmente formando grupos en forma de "abanico"; o en 
las especies con hojas plegadas las células buliformes están escasamente diferenciadas de las restantes células epidérmicas.

\section{Caracterización de la micromorfología epidérmica foliar}

Sobre las observaciones realizadas en la epidermis adaxial y abaxial con MEB en las especies de Festuca del Cono Sur, se seleccionaron los caracteres micromorfológicos que resultaron variables entre las especies. A continuación se mencionan y describen brevemente cada uno de ellos.

- Distinción entre zonas costales e intercostales (superficie homogénea vs. heterogénea)

Las células epidérmicas dispuestas sobre los haces usualmente varían a las dispuestas entre haces vasculares (indistintamente si existen surcos y costillas diferenciados). En las especies de Festuca con láminas abiertas las superficies adaxial y abaxial son heterogéneas. En cuanto a las especies con láminas permanentemente plegadas, siempre la superficie adaxial es heterogénea, mientras que la superficie abaxial puede ser completamente homogénea (p. ej. F. monticola, $F$. subantarctica) o ligeramente heterogénea (p. ej. F. fiebrigii, F. hieronymi).

\section{- Asperezas}

Las asperezas se presentan en Festuca como estructuras epidérmicas agudas con su base hundida en la epidermis, en general son curvados y pueden estar silicificados, dando un aspecto escabroso a la lámina. Generalmente se distinguen aguijones, con base oval y mayor longitud, y ganchos con base redondeada y menor longitud; en la especies estudiadas de Festuca frecuentemente los aguijones son más comunes en la epidermis adaxial, mientras que los ganchos lo son epidermis abaxial, pero como esta distinción resultó imprecisa se optó por el término aspereza para incluir todas éstas estructuras.

\section{- Macropelos}

Los macropelos observados son estructuras unicelulares con diferente longitud y curvatura. En todos los casos se presentan con el ápice agudo y la base ligeramente dilatada, rodeada por células epidérmicas semejantes a las restantes. Pueden estar ausentes en ambas epidermis como en $F$. subantarctica, o estar presentes sólo en la epidermis adaxial, condición que es más común entre las especies estudiadas. 
- Cuerpos silíceos

Los cuerpos silíceos son depósitos discretos de sílice que en el caso de Festuca varían de redondeados a elípticos, en algunos casos ligeramente cuadrangulares. Lo más frecuente es que estén presentes sólo en la epidermis abaxial, mientras que en la epidermis adaxial fueron observados en pocas especies como por ejemplo $F$. arundinacea, F. ulochaeta, F. parodiana.

- Papilas

Las papilas son estructuras epidérmicas formadas por una expansión de la pared tangencial externa de la célula epidérmica y solamente fueron observadas en la epidermis adaxial de $F$. monticola.

\section{- Complejos estomáticos}

El complejo estomático incluye a las células oclusivas que son invariables en cuanto a su forma en las Poaceae, y a las células subsidiarias que también participan del movimiento estomático. En las especies estudiadas de Festuca, las células subsidiarias son del tipo en domo bajo o con los lados paralelos. La distribución de estomas más frecuente observada es en 1-4 filas, separados por una o más células epidérmicas, en las zonas intercostales de la superficie adaxial, y comúnmente la epidermis abaxial carece de estomas, con la excepción de $F$. arundinacea, $F$. ulochaeta y F. superba.

\section{- Células epidérmicas}

En cuanto a las células epidérmicas vista en superficie, pueden caracterizarse según su forma y como son sus paredes anticlinales. En general se observan células largas y angostas que según su longitud relativa se las clasifica aquí en elongadas cuando son de 5 veces a más el largo sobre el ancho, condición que caracteriza a la epidermis abaxial de las especies de Festuca. Las células epidérmicas adaxiales (descritas en las zonas costales) son algo más cortas, del tipo rectangular, 2 a 5 veces más larga que anchas, o en algunos pocos casos como $F$. fimbriata, $F$. parodiana, F. rubra, F. purpurascens, del tipo fusiforme, hexagonalmente elongadas. Las paredes anticlinales de las células abaxiales pueden ser desde lisas (menos frecuente) como en $F$. parodiana, F. fimbriata; hasta muy gruesas y con repliegues en forma de $\Omega$ como en $F$. magellanica, F. pyrogea, F. yalaensis; mientras que en la epidermis adaxial son frecuentemente sinuosas a onduladas. 
- Forma y densidad de ceras epicuticulares

La presencia de ceras epicuticulares fue detectada en ambas epidermis de Festuca; en algunos casos dispuesta de manera continua como es más frecuente en la epidermis abaxial o formando cristaloides de diferente aspecto más frecuentemente en la epidermis adaxial. Si bien en la mayoría de los casos los cristaloides tienen aspecto de pequeñas varillas, en algunos casos no puede describirse con precisión la forma de los mismos, dado que algunos ejemplares de herbario no se conservan en óptimas condiciones. Por ello, se optó por describir la presencia o ausencia de cristaloides en las ceras epicuticulares, y no atribuirle un tipo en particular.

\section{Análisis numérico}

El fenograma obtenido (índice de correlación cofenético $=0,81$ indicando un buen ajuste entre el fenograma y la matriz de distancia) muestra dos grandes conglomerados separados a distancia 1.18 que separan las especies del cluster A, comúnmente caracterizadas como de "hoja ancha", y las del cluster B en general llamadas de "hoja fina"; dentro de este último cluster se distinguen los grupos B1, B2 y B3 (Figura 1). Dado estos grupos de especies con afinidad anatómico y micromorfológica, se definen diferentes tipos foliares que se caracterizan según lo explicado a continuación.

Las especies del cluster A se caracterizan por presentar la forma del transcorte plano, expandido, con superficie abaxial irregular y superficie adaxial con surcos y costillas de moderadas a bien diferenciadas, en varios casos con costilla central bien desarrollada con parénquima incoloro asociada a varios haces vasculares (excepto en $F$. hieronymi y $F$. nemoralis), haces con trabas adaxiales y abaxiales de esclerénquima (o extensiones de parénquima engrosado), células buliformes bien diferenciadas en forma de abanico, sin macropelos en la epidermis adaxial, y estomas siempre presentes en la epidermis adaxial y en algunos casos, también en la epidermis abaxial como en $F$. arundinacea, $F$. superba y $F$. ulochaeta (Figura 2).

Las especies del subcluster B1 se distinguen por presentar transcortes en forma de "U", conduplicados, con costillas y surcos adaxiales muy marcados, sin costilla central diferenciada, un anillo esclerenquimático continuo abaxial desarrollado, células buliformes muy poco diferenciadas de las restantes epidérmicas, abundantes macropelos y asperezas principalmente en la superficie adaxial, aunque esto último es algo más variable entre las especies de este grupo. Dentro de este tipo foliar, se incluye $F$. monticola, única especie dentro de las Festucas del Cono Sur que presentó papilas en la superficie adaxial de las láminas (Figura 3). 
Las especies del subcluster B2 comparten con las del B1 la presencia de transcortes mayoritariamente en forma de "U" (a veces en "V"), conduplicados, con costillas y surcos adaxiales muy marcados, sin costilla central diferenciada, las células buliformes poco diferenciadas de las restantes epidérmicas. Pero se diferencian por carecer de anillo continuo de esclerénquima, en cambio este tejido se dispone formando trabas adaxiales y/o abaxiales asociadas a los haces vasculares. Presentan frecuentemente numerosas asperezas adaxiales y algunas veces también abaxiales (Figura 4).

Las especies del subcluster B3 son las más variables entre sí en cuanto a la forma del transcorte, siempre conduplicado, pero en forma de "U" o en "V", el anillo abaxial de esclerénquima puede ser continuo o no, pero en caso de ser continuo no se prolonga formado trabas en los haces vasculares como se observa en $F$. magellanica, F. pyrogea, F. ventanicola por ejemplo; también el esclerénquima puede presentarse formado casquetes abaxiales y en algunas especies también adaxiales como en F. kurtziana, F. roigii. Los demás caracteres epidérmicos como macropelos, asperezas, cuerpos silíceos, etc., resultaron variables entre las especies de este grupo (Figura 5).

$\underline{\text { Relación entre el tipo foliar y la distribución altitudinal de las especies }}$

Tabla 1. Listado de especies del Cono Sur, junto con el tipo foliar correspondiente y los límites altitudinales (m s.m.) inferior y superior de la distribución geográfica.

\begin{tabular}{lccc}
\hline \multicolumn{1}{c}{ ESPECIE } & $\begin{array}{c}\text { TIPO } \\
\text { FOLIAR }\end{array}$ & $\begin{array}{c}\text { Límite } \\
\text { altitudinal } \\
\text { menor }\end{array}$ & $\begin{array}{c}\text { Límite } \\
\text { altitudinal } \\
\text { mayor }\end{array}$ \\
\hline 1-a. Festuca acanthophylla var. acanthophylla & B1 & 1000 & 3000 \\
1-b. Festuca acanthophylla var. scabriuscula & B1 & 700 & 2200 \\
2. Festuca argentina & B2 & 50 & 1500 \\
3. Festuca argentinensis & B1 & 3200 & 4600 \\
4. Festuca arundinacea & A & 300 & 2370 \\
5. Festuca castilloniana & B2 & 2000 & 3600 \\
6. Festuca chrysophylla & B1 & 3200 & 4900 \\
7. Festuca cirrosa & B1 & 0 & 175 \\
8. Festuca contracta & B3 & 200 & 1000 \\
9. Festuca dissitiflora & B2 & 1000 & 4500 \\
10. Festuca distichovaginata & B1 & 3900 & 4100 \\
11. Festuca fiebrigii & B2 & 2200 & 3000 \\
12. Festuca fimbriata & A & 0 & 2000 \\
13-a. Festuca gracillima var. gracillima & B3 & 0 & 900 \\
13-b. Festuca gracillima var. glacialis & B3 & 0 & 1300 \\
14. Festuca hieronymi & A & 400 & 3000
\end{tabular}




\begin{tabular}{lccc} 
15. Festuca hypsophila & B1 & 3200 & 4800 \\
16. Festuca kurtziana & B3 & 1600 & 2800 \\
17. Festuca lasiorrhachis & B2 & 2800 & 3400 \\
18. Festuca lilloi & B2 & 2300 & 3900 \\
19. Festuca magellanica & B3 & 0 & 3500 \\
20. Festuca monticola & B1 & 500 & 1550 \\
21. Festuca nardifolia & B3 & 3900 & 5000 \\
22. Festuca nemoralis & $\mathrm{A}$ & 1000 & 3000 \\
23. Festuca ovina subsp. tenuifolia & $\mathrm{B} 3$ & 0 & 600 \\
24. Festuca pallescens & $\mathrm{B} 3$ & 0 & 900 \\
25. Festuca pampeana & $\mathrm{B} 3$ & 500 & 1000 \\
26. Festuca panda & $\mathrm{B} 3$ & 2900 & 3400 \\
27. Festuca parodiana & $\mathrm{A}$ & 2000 & 2900 \\
28. Festuca parodii & $\mathrm{B} 2$ & 2500 & 3500 \\
29. Festuca purpurascens & $\mathrm{A}$ & 0 & 500 \\
30. Festuca pyrogea & $\mathrm{B} 3$ & 100 & 1100 \\
31. Festuca rigescens & $\mathrm{B} 3$ & 2500 & 4800 \\
32. Festuca roigii & $\mathrm{B} 3$ & 1500 & 2800 \\
33. Festuca rubra & $\mathrm{B} 3$ & 0 & 1800 \\
34. Festuca subantarctica & $\mathrm{B} 1$ & 0 & 175 \\
35. Festuca superba & $\mathrm{A}$ & 2000 & 2500 \\
36. Festuca ulochaeta & $\mathrm{A}$ & 0 & 1000 \\
37. Festuca uninodis & $\mathrm{B} 2$ & 3600 & 4500 \\
38. Festuca ventanicola & $\mathrm{B} 3$ & 500 & 1000 \\
39. Festuca weberbaueri & $\mathrm{B} 2$ & 2800 & 4200 \\
40. Festuca werdermannii & $\mathrm{B} 3$ & 2800 & 4200 \\
41. Festuca yalaensis & $\mathrm{B} 2$ & 2000 & 2200 \\
\hline
\end{tabular}

En relación a la mínima altitud, puede observarse en la Figura 6 que los cuatro tipos foliares (A, B1, B2, B3) tienen especies que crecen a nivel del mar. Sin embargo, en relación al límite superior, el tipo A (en verde) sólo llega hasta los 3000 m s.m., mientras que los tipos B1 (en rojo), B2 (en azul) y B3 (en marrón) logran mayores altitudes, a casi los 5000 m s.m. en los tipos B1 y B3. Para el tipo B1, de las 9 especies que representan este tipo, 6 de ellas tienen un límite distribucional por arriba de los 2000 m s.m.; para el B2 casi la totalidad (excepto uno especie) llegan hasta por arriba de los 3000 m s.m.; esto indica que ambos tipos foliares están mejor representados en zonas de mayor altitud. En cambio, las especies del tipo B3, que es el más representativo entre las Festuca estudiadas, se reparten equitativamente, casi la mitad de sus especies llegan hasta zonas bajas (inferior a los $2000 \mathrm{~m} \mathrm{s.m}$.) y la otra mitad logran mayores altitudes hasta los $5000 \mathrm{~m}$ s.m. 


\section{DISCUSIÓN}

El cluster A incluye a $F$. arundinacea, $F$. fimbriata, $F$. hieronymi, F. nemoralis, $F$. parodiana, $F$. purpurascens, $F$. superba y $F$. ulochaeta. Estas especies desarrollan en ambientes que no superan los 3000 m s.m., y la mayoría crecen preferencialmente desde el nivel del mar o bajas altitudes, excepto $F$. parodiana y $F$. superba que presentan un rango más limitado creciendo a partir de los $2000 \mathrm{~m}$ s.m. Los caracteres foliares que presentan las especies de este grupo, se relacionan con los ambientes donde desarrollan, ya que al tener láminas planas y abiertas, reciben mayor exposición a la radiación solar, asimismo la falta de tejido esclerenquimático muy desarrollado las hace más susceptibles a los fuertes vientos que predominan en zonas más altas y áridas en las cuales no podrían desarrollar. Sin embargo, algunas de ellas logran habitar lugares de mayor altitud, como por ejemplo $F$. parodiana, que puede crecer en la provincia Altoandina (Catalán \& Müller 2012). En estos casos, la presencia de células buliformes bien desarrolladas, les permitiría enrollarse temporalmente reduciendo la superficie de exposición en las horas de mayor exposición como respuesta directa para mantener el balance hídrico de la planta (Cutler 1987; Rudall 2007). En caso que esto suceda, éstas especies se enrollan de manera convoluta (lámina enrollada sobre sí misma) o involuta (lámina con sus márgenes curvados hacia la cara superior de la misma), a diferencia de las restantes especies estudiadas que son conduplicadas. La mayoría de las especies del tipo A son componentes importantes en campos graminosos de la provincia biogeográfica de las Yungas o selvas Paranaense, como por ejemplo F. fimbriata, F. ulochaeta, etc.; y aunque pueden crecer en zonas inundables o márgenes de arroyos, ninguna de ellas desarrolla aerénquima en sus láminas foliares, típico tejido de plantas hidrófilas.

El subcluster B1 incluye $F$. acanthophylla var. acanthophylla, $F$. cirrosa, $F$. argentinensis, $F$. acanthophylla var. scabriuscula, $F$. distichovaginata, F. monticola, $F$. subantarctica, $F$. chrysophylla y $F$. hypsophila. Las especies que presentan este patrón foliar son elementos florísticos característicos de las estepas graminosas de las provincias Altoandina, del Desierto, Puneña, Subantartica y Patagónica (Cabrera \& Wilink 1973). Dichos ambientes se caracterizan por la elevada radiación solar, vientos con alta velocidad y suelos pobres en materia orgánica, además de la presencia de nieve y suelos congelados en algunos casos. Si bien algunas de estas especies pueden crecer en zonas bajas, como por ejemplo $F$. cirrosa y $F$. subantarctica, la mayoría prefiere áreas de mayor altitud como $F$. chrysophylla que logra casi los $5000 \mathrm{~m}$ s.m., creciendo en suelos arenosos o rocosos de las laderas de alta montaña.

Las características histofoliares de todas estas especies permiten clasificarlas como xerófitas (Stace, 1965; Ellis 1979). El desarrollo abundante de esclerénquima (estructura anatómica con fines mecánicos) en la superficie abaxial de las láminas, le otorga rigidez a las hojas, además de 
protección al escaso tejido fotosintético que queda limitado a la superficie adaxial más protegida. Asimismo, este tipo de hojas están permanentemente plegadas de manera conduplicada, dejando expuestas solamente la superficie abaxial. No se observó en ningún caso estomas en la epidermis abaxial, todos ellos siempre ubicados en los surcos de superficie adaxial, carácter que también da protección contra la gran amplitud térmica, elevada evapotranspiración por la alta radiación solar, y también evitar el congelamiento en algunos acaso (Evert 2006, Rudall et al. 2007).

El subcluster B2 se compone de $F$. argentina, $F$. dissitiflora, $F$. castilloniana, $F$. uninodis, $F$. yalaensis, F. fiebrigii, F. lilloi, F. parodii, F. lasiorrachis y F. weberbaueri. Las especies de este grupo pueden vivir desde el nivel del mar como $F$. argentina, pero la mayoría se distribuyen a partir de los $2000 \mathrm{~m}$ s.m. hasta casi los $4500 \mathrm{~m}$ s.m. como F. dissitiflora. Este patrón anatómico, semejante a lo que ocurre con el grupo B1, se distribuyen principalmente en lugares xerófilos, con gran amplitud térmica, alta radiación solar y con presencia de nieve, en al menos una estación del año, como son las provincias fitogeográficas de la Puna y Altoandina (Cabrera \& Wilink 1973). A pesar de ello, su patrón anatómico difiere por el hecho que el esclerénquima se dispone formando trabas que si bien dan cierta rigidez a las láminas, permite que el tejido fotosintético quede expuesto a la luz solar en ambas superficies, contrario al tipo B1 donde sólo queda expuesto en la superficie adaxial. Por otro lado, si las células buliformes de las especies del tipo B2 fuesen metabólicamente activas, podrían abrir o plegar parcialmente la lámina, según la intensidad de la radiación solar, hecho que no podría ocurrir en las tipo B1 por la presencia del anillo esclerenquimático. De esta manera, las especies del tipo B1 y B2 cohabitan en los mismos tipos de hábitats, como la provincia Altonadina por ejemplo, y están sometidas a similares situaciones de estrés, pero cada grupo presentaría diferentes estrategias en las estructuras foliares, con la misma finalidad de desarrollarse en ambientes algo extremos.

El subcluster B3 está compuesto por $F$. contracta, $F$. gracillima var. gracillima, $F$. gracillima var. glacialis, F. rubra, F. nardifolia, F. pampeana, F. ventanicola, F. ovina subsp. tenuifolia, $F$. pallescens, $F$ rigescens, F. panda, F. kurtziana, F. roigii, F. magellanica, F. pyrogea y $F$. werdermannii. A este grupo pertenece el mayor número de especies de Festuca del Cono Sur (15 sobre 41 especies), y se distribuyen equitativamente desde el nivel del mar hasta casi los 5000 m s.m., siendo $F$. nardifolia la especie que logra mayor altitud la cual crece formando cojines en las altas montañas de los Andes argentino.

En relación a la validez de los caracteres anatómicos y micromorfológicos en las especies de Festuca del Cono Sur, se observó que los de mayor significancia resultaron ser la forma del transcorte, tipo de plegamiento $\mathrm{y}$ grado de desarrollo $\mathrm{y}$ distribución del tejido esclerenquimático. Contrariamente a lo que sugieren otros autores (Stančík \& Peterson 2007), 
se observó que el número de haces vasculares varía a nivel intraespecífico, por lo que tendría un limitado valor.

En cuanto a las estructuras epidérmicas, generalmente se las considera que son constantes y con localización predecible (Ellis, 1979), y dado que su forma y distribución tienen un limitado grado de variación, usualmente se los considera informativos en taxonomía (Ortuñez \& de la Fuente, 2010). En este estudio, se observó que algunas de ellas como las asperazas y macropelos, por ejemplo, presentan cierta variación intarespecífica a nivel de la densidad según la zona de la lámina que se observa. Las zonas costales de la epidermis abaxial, usualmente presentan numerosos cuerpos silíceos, mientras que la epidermis adaxial presenta pocos o puede carecer de ellos. Los cuerpos silíceos pueden presentarse aislados o formando pares con células suberosas, y algunos estudios realizados en el género Festuca probaron que el tamaño y frecuencia de los cuerpos silíceos esta en gran parte determinado genéticamente, independiente de las condiciones ambientales (Dani 2014).

En cuanto a las ceras epicuticulares, algunos autores las consideran de gran utilidad en el género, para diferenciar especies ya que pueden presentarse de formando cristaloides con distintas formas como plaquetas, hilos, varillas (Ortuñez \& de la Fuente 2010; Ortuñez \& CanoRuiz 2013). En las especies aquí estudiadas no fue posible en todos los casos determinar la forma de los cristaloides, en parte por el grado de conservación del material estudiado. Por ello se optó por diferenciar especies con cristaloides (más allá de cual sea la forma) de especies con ceras epicuticulares dispuestas en una lámina continua (es decir no forman cristaloides). Se observó que el tipo foliar A presenta ceras epicuticulares en forma de cristaloides en ambas superficies, el tipo B1 sólo en la epidermis abaxial, y los tipos B2 y B3 preferentemente sólo en la epidermis adaxial. Las ceras epicuticulares tienen un rol ecológico muy importante en la interacción entre las plantas y el medio ambiente (Barthlott et al. 1998), principalmente en el equilibrio hídrico de las plantas (Eglinton \& Hamilton 1967). Las diferencias halladas en relación a la presencia de cristaloides en alguna o ambas epidermis de la lámina, según los tipos foliares de las especies de Festuca, podría estar relacionado en parte con la superficie foliar que está en mayor contacto con el medio externo.

Se evidencia que la caracterización de los atributos anatómicos y micromorfológicos foliares en conjunto pueden utilizarse para el reconocimiento de ciertas especies de Festuca aquí estudiadas. En los estudios filogenéticos (Torrecilla \& Catalán 2002; Catalán et al. 2004; Catalán 2006; Inda et al. 2008) siempre se hace referencia a dos linajes diferentes: las especies de Festuca con las hojas anchas (que serían linajes más basales) y las especies con hojas finas (que representarían linajes más modernos). Según los patrones aquí observados, las primeras corresponderían a tipo $\mathrm{A}$, mientras que las segundas a los tipos $\mathrm{B}$, aunque dentro de éste último 
pueden reconocerse tres subtipos diferentes (B1, B2 y B3). Desde la exomorfología, las más difíciles de caracterizar son las especies de "hoja fina" que muchas veces se las describe como presentando láminas aciculares, setáceas, filiformes, junciformes, etc. Así, el criterio morfológico para definir este tipo de lámina resulta impreciso y puede o no corresponderse con diferentes estructuras internas de la lámina. Es más, algunas láminas angostas que carecen de anillo esclerenquimático continuo, como las del tipo B2 y algunas especies del B3, tendrían la posibilidad de plegarse y expandirse en cierto grado, si las células buliformes fuesen activas, pudiendo ser "más anchas" o "menos finas" según en que estado se las observe. Tal podría ser el caso de $F$. argentina, que según sus relaciones filogenéticas, se la considera de "hoja ancha" (Inda et al. 2008), mientras que aquí se las define por su estructura foliar dentro de los grupos comúnmente denominados "hoja fina". De acuerdo a lo expuesto, parecería más apropiado observar cual es la estructura histológica de la lámina, más que clasificarlas como "hoja ancha" u "hoja fina", ya que estos dos modelos incluyen mayor diversidad de caracteres. 


\section{FIGURAS}

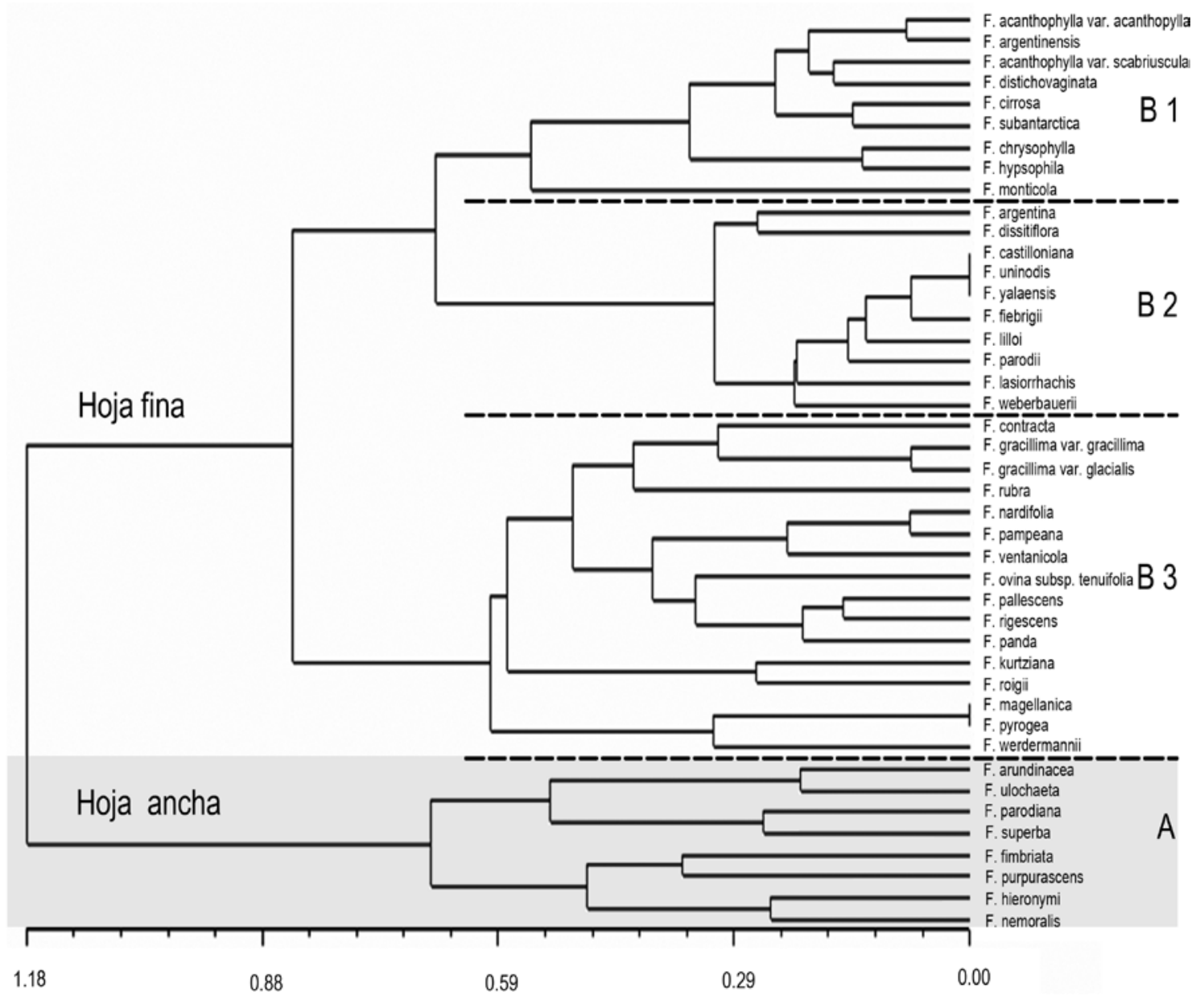

Figura 1. Fenograma obtenido a partir del análisis de conglomerados con el algoritmo UPGMA. 


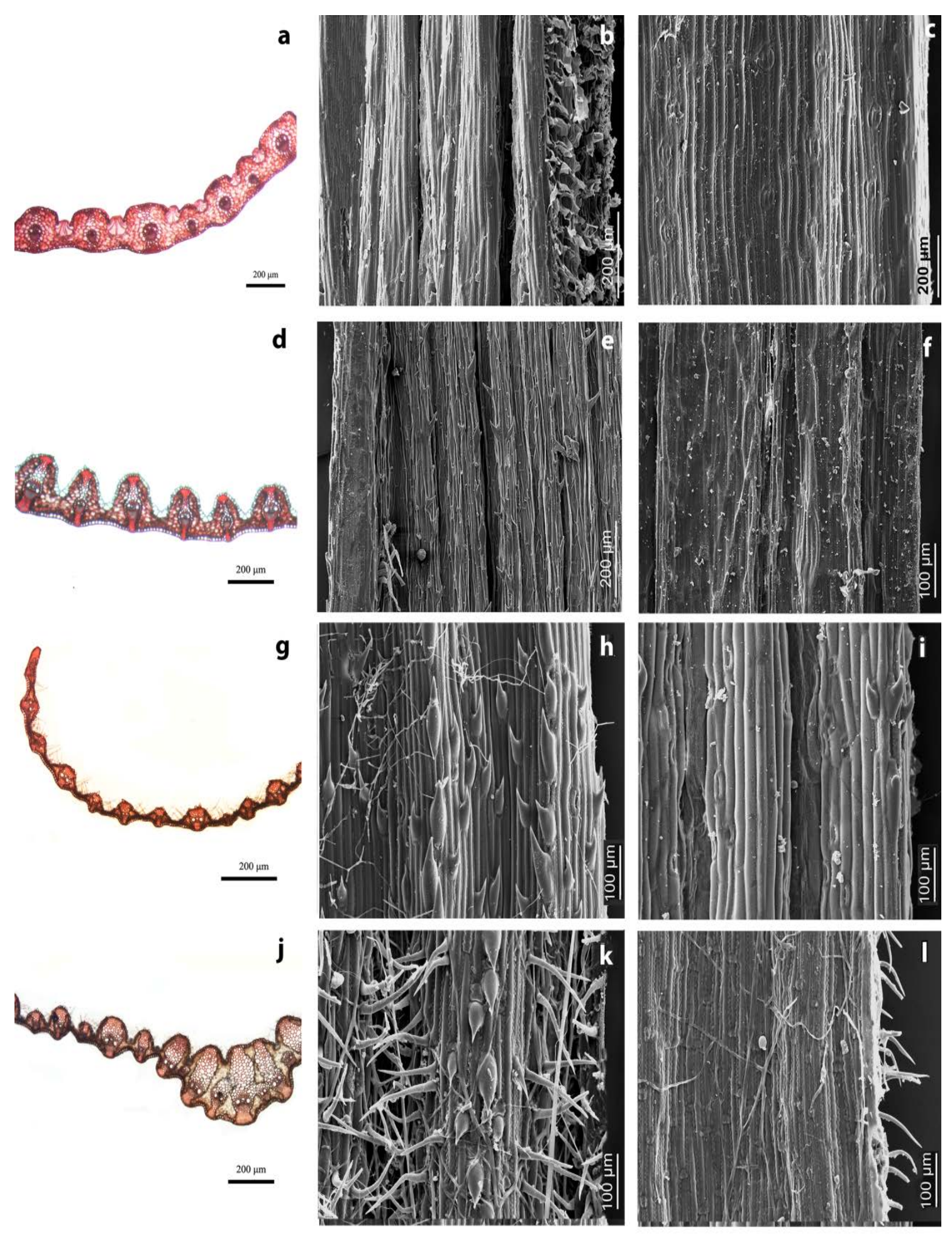

Figura 2. a-c, Festuca arundinacea (a, Denham \& Múlgura 275, SI; c-d, Morrone 6266, SI). df, Festuca purpurascens (d, Peterson et al. 17401, SI; e-f, Morrone 6110, SI). g-i, Festuca superba (Cabrera 18879, SI). j-1, Festuca ulochaeta (Múlgura et al. 3208, SI). a, d, g, j. Corte transversal de lámina foliar vista en microscopio óptico. b, e, h, k. Epidermis adaxial de lámina foliar vista en microscopio electrónico de barrido. c, f, i, 1. Epidermis abaxial de lámina foliar vista en microscopio electrónico de barrido. 


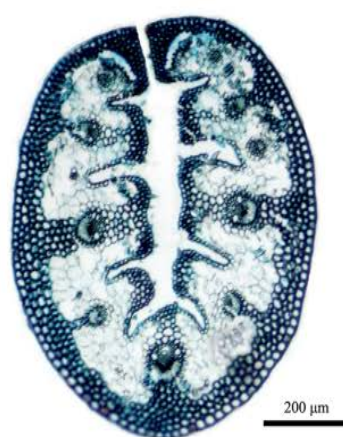

a
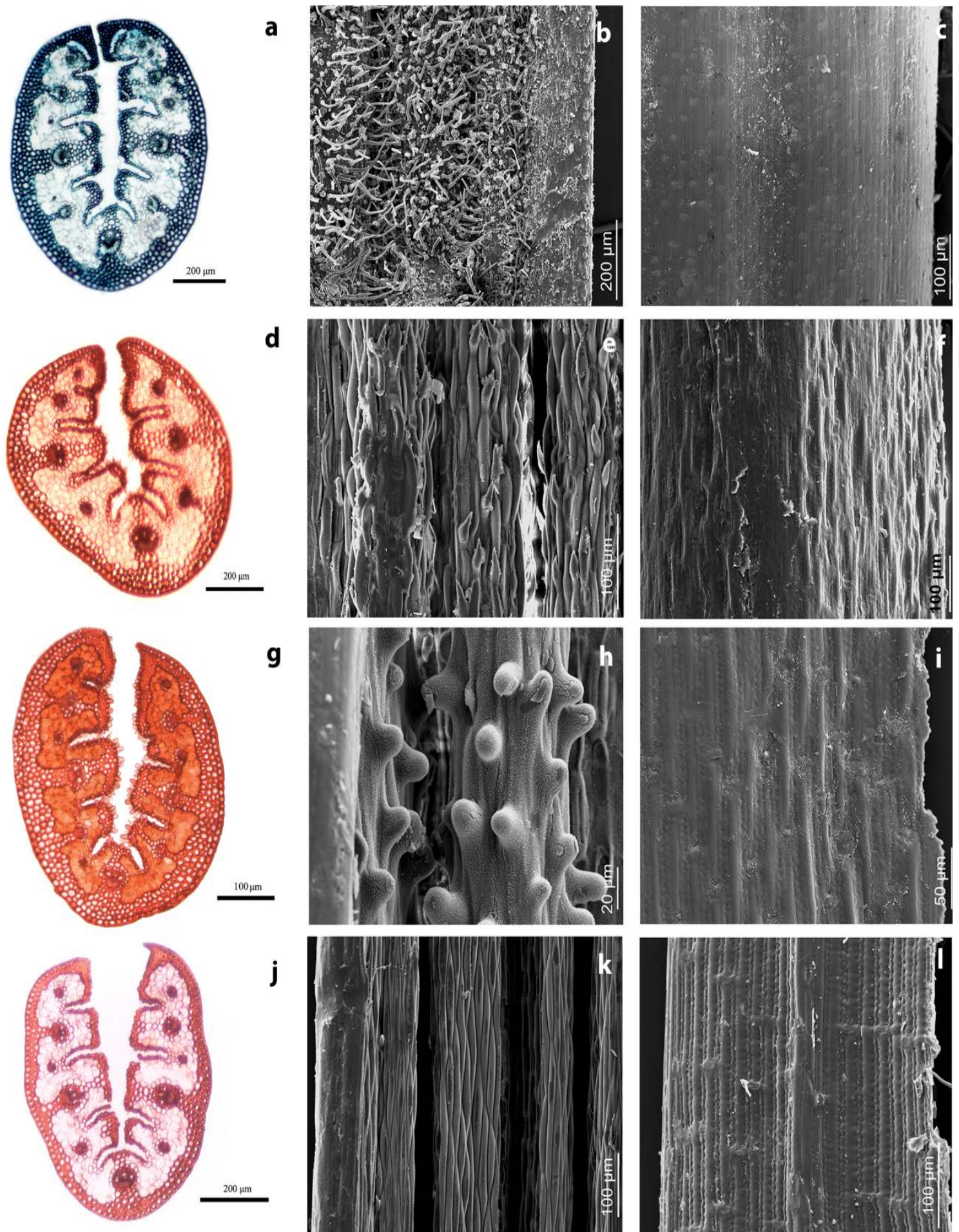

Figura 3. a-c, Festuca acanthophylla var. acanthophylla (a, Duvcobsky \& Martinez 234, BAB; c-d, Ducovsky \& Martínez 250, BAB). d-f, Festuca cirrosa (d, Biganzoli 505, SI; e-f, Pisano 6600, SI). g-i, Festuca monticola (g, Werdermann 1268, SI; h-i, Diem 769, CONC). j-1, Festuca subantarctica (j, Pisano s.n. T.B.P.A. 2838, SI; k-1, Pisano 4431, CONC). a, d, g, j. Corte transversal de lámina foliar vista en microscopio óptico. b, e, h, k. Epidermis adaxial de lámina foliar vista en microscopio electrónico de barrido. c, f, i, 1. Epidermis abaxial de lámina foliar vista en microscopio electrónico de barrido. 

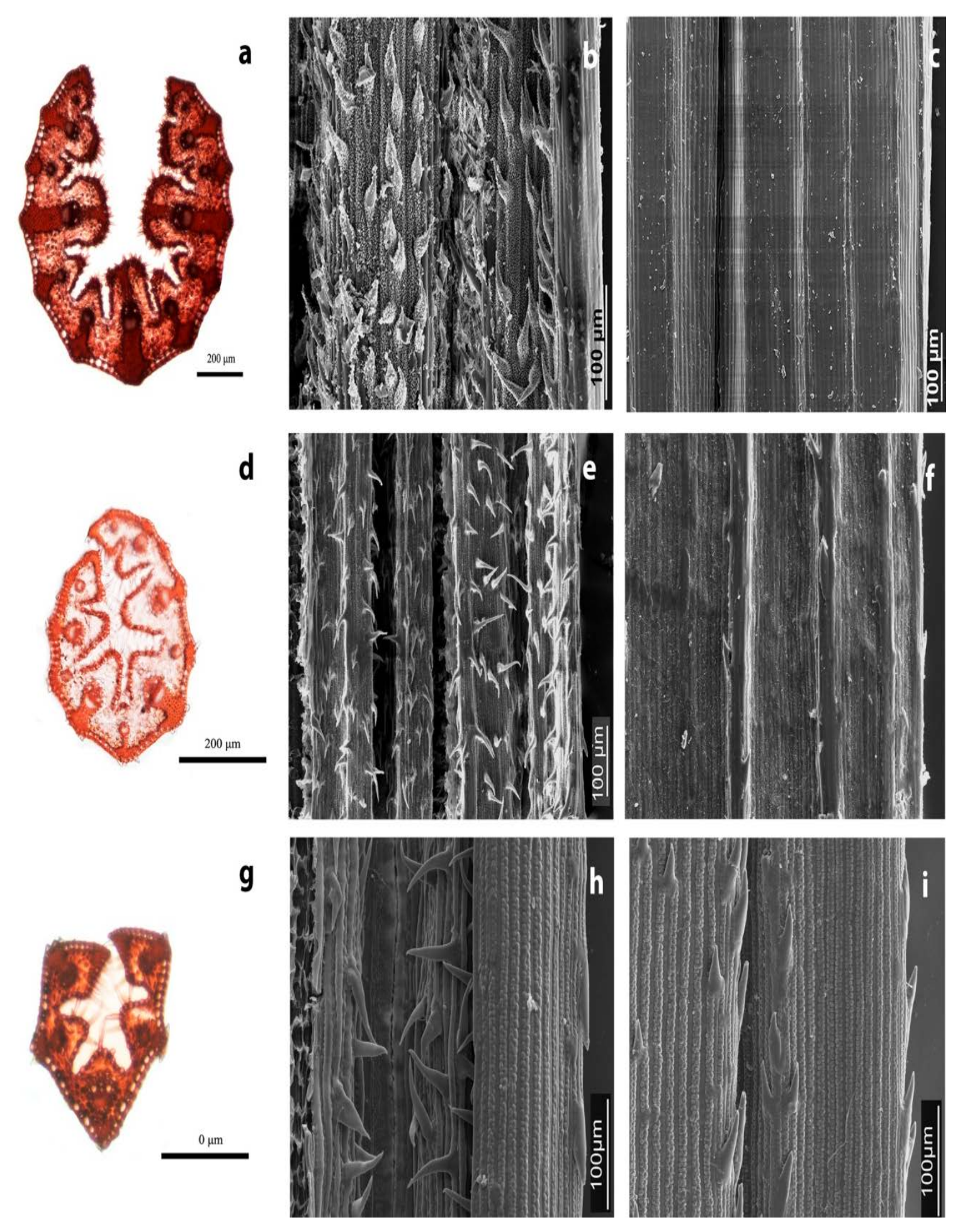

Figura 4. a-c, Festuca argentina (a, Boelcke et al. 15435, SI; b-c, Biganzoli 2274, SI). d-f, Festuca dissitiflora (d-f, Zuloaga et al. 13081, SI). g-i, Festuca lilloi (g, Burkart 5298, SI; h-i, Rodríguez 1326, SI). a, d, g. Corte transversal de lámina foliar vista en microscopio óptico. b, e, h. Epidermis adaxial de lámina foliar vista en microscopio electrónico de barrido. c, f, i. Epidermis abaxial de lámina foliar vista en microscopio electrónico de barrido. 


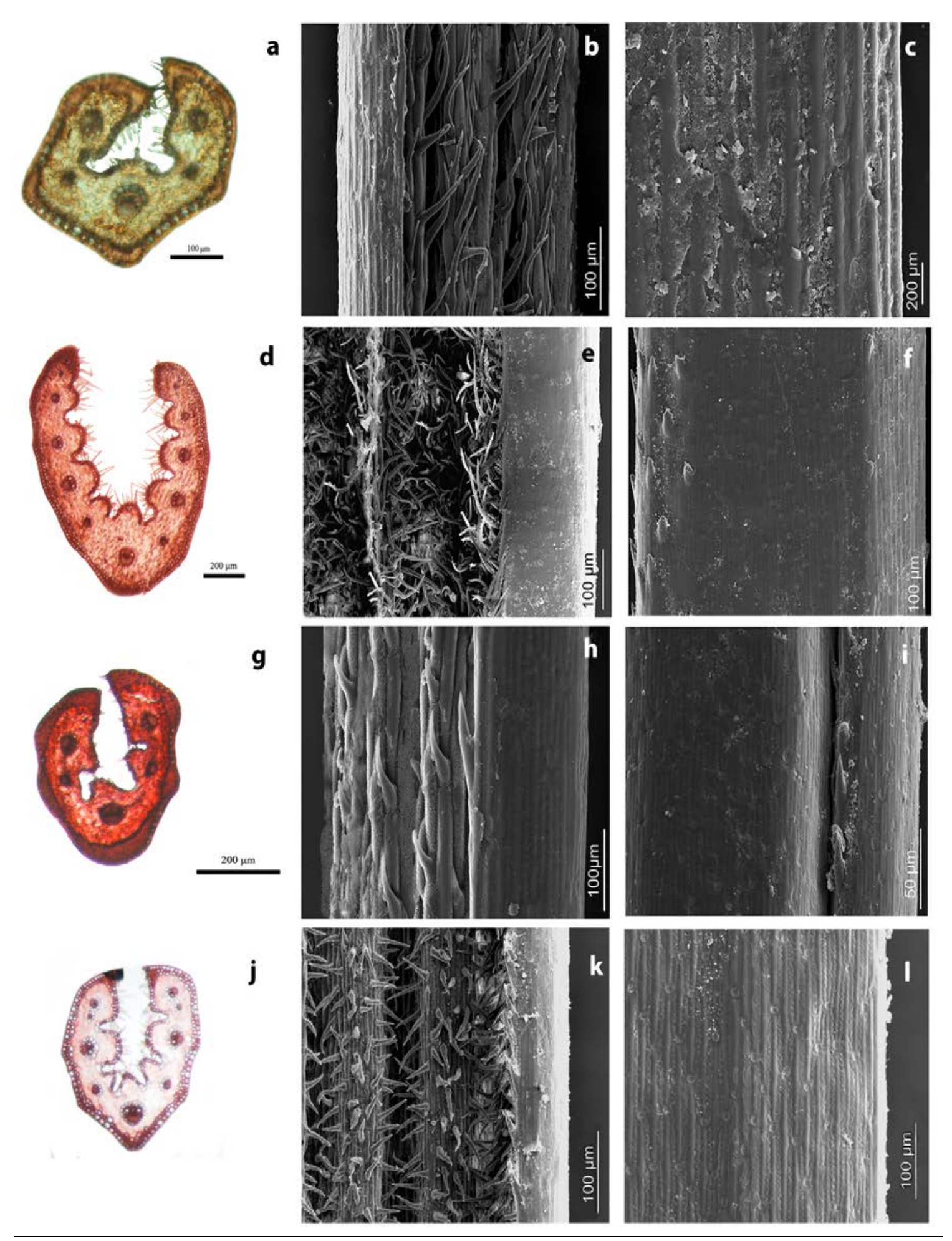

Figura 5. a-c, Festuca gracillima var. glacialis (d, sin colector T.B.P.A. 2535, SI; e-f, Zuloaga 14090, SI). d-f, Festuca kurtziana (a, Araya s.n., CONC 7257; b-c, Sede 378a, SI). g-i, Festuca magellanica (Peterson et al. 17271, SI). j-1, Festuca pallescens (d, Peterson et al. 17231, SI; hi, Peterson et al. 17137, SI).a, d, g, j. Corte transversal de lámina foliar vista en microscopio óptico. b, e, h, k. Epidermis adaxial de lámina foliar vista en microscopio electrónico de barrido. c, f, i, l. Epidermis abaxial de lámina foliar vista en microscopio electrónico de barrido. 


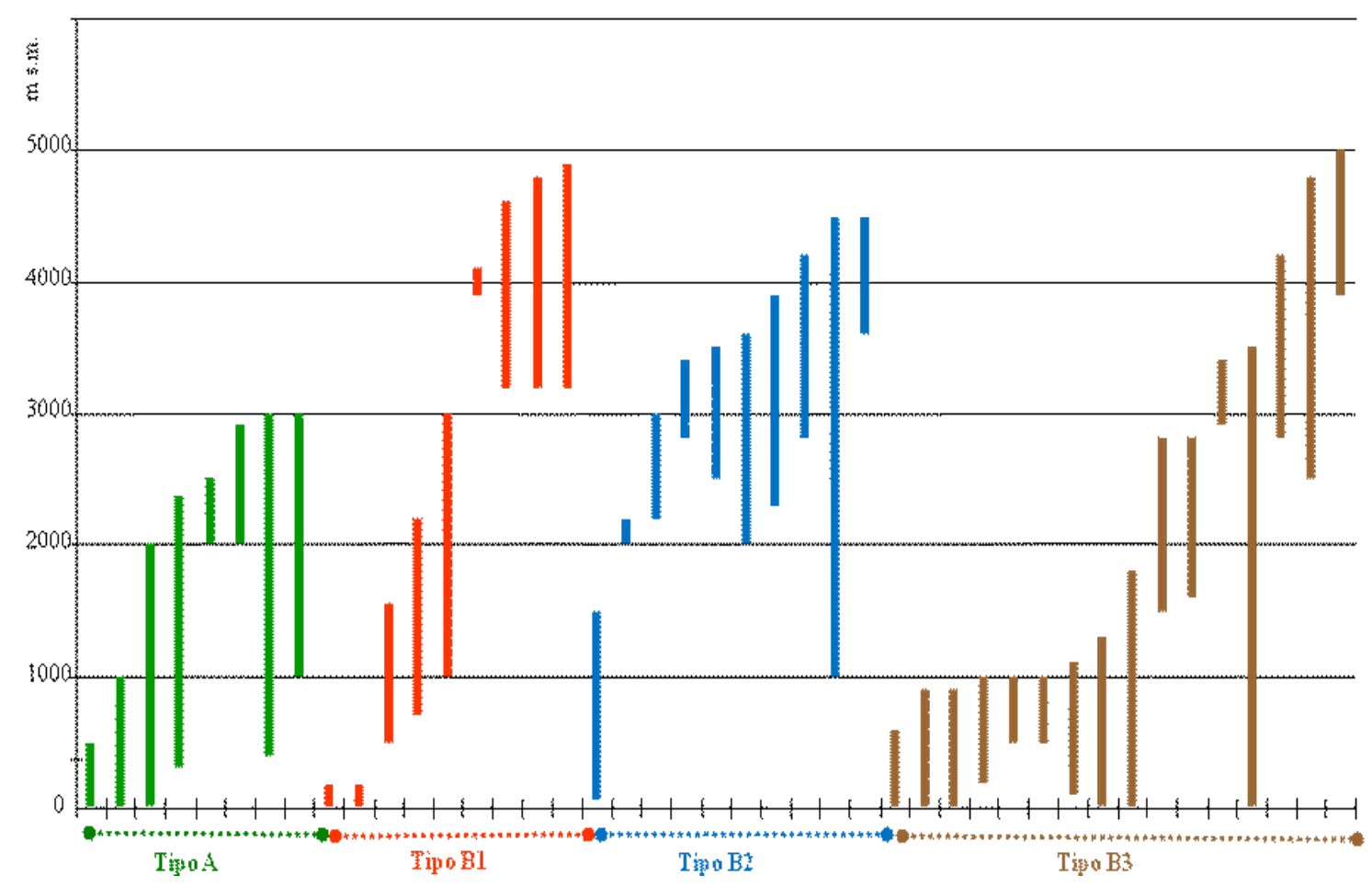

Figura 6. Relación entre las especies de Festuca del Cono Sur según su tipo foliar y el rango altitudinal de distribución geográfica. 


\title{
CAPÍTULO V
}

\section{APROXIMACIÓN A LAS RELACIONES FILOGENÉTICAS DE LAS ESPECIES SUDAMERICANAS DE FESTUCA}

\begin{abstract}
ANTECEDENTES
Los primeros estudios filogenéticos con datos moleculares de la subfamilia Pooideae se realizaron a partir de secuencias del marcador plastidial ndhF (Soreng et al. 1990; Catalán et al. 1997). Posteriormente, se han llevado a cabo análisis filogenéticos de esta subfamilia sobre la base de las secuencias de los genes atpB-matK y ndhF junto con caracteres morfológicos y anatómicos (Soreng et al. 2007) que permitieron establecer nuevas clasificaciones dentro de la subfamilia y esclarecer las relaciones filogenéticas de la subtribu Loliinae que contiene a los representantes del género Festuca L. y géneros derivados de éste.
\end{abstract}

Varios estudios con datos moleculares se enfocaron en el análisis de las interrelaciones del género Festuca y géneros afines, especialmente Vulpia C.C. Gmel. y Lolium L. Algunos de estos trabajos ofrecen información acerca de la variación en la estructura del ADN entre los representantes de estos géneros, usando marcadores como RFLP y RAPD (Darbyshire \& Warwick 1992, Xu \& Sleper 1994; Stammers et al. 1995; entre otros).

Luego se realizaron una serie de trabajos filogenéticos con representantes de Festuca s.1. usando secuencias nucleotídicas del marcador nuclear ITS (Charmet et al. 1997, Gaut et al. 2000, Torrecilla \& Catalán 2002) que mostraron al género Festuca como parafilético con Lolium y Vulpia incluidos en él.

Torrecilla \& Catalán (2002) distinguen los linajes hoja ancha (con bajo soporte) y hoja fina (con buen soporte) en la subtribu Loliinae. También, sobre la base del marcador nuclear ITS, evidencian la relación filogenética de Lolium con el grupo de festucas de hoja ancha, particularmente con el subgénero Schedonorus de Festuca. Por su parte, Vulpia aparece relacionado con el linaje hoja fina. Estas relaciones intergenéricas ya habían sido planteadas a partir de ensayos de cruzamientos interespecíficos artificiales (Barker \& Stace 1982) y de análisis de cromosomas (Malik \& Thomas 1966).

Posteriormente, Torrecilla et al. (2003) incrementaron el muestreo taxonómico (con especies europeas principalmente) y analizaron secuencias nucleotídicas del marcador plastidial trnL-F junto a ITS en un análisis filogenético de mayor alcance. Como resultado, varios géneros 
pequeños, de especies anuales y originarias del área del Mediterráneo se incorporaron al linaje hojas finas de Loliinae: Psilurus Trin., Ctenopsis De Not., Narduroides Rouy, Wangenheimia Moench, Cutandia Willk. y Micropyrum (Gaudin) Link.

Catalán et al. (2004), incluyeron más taxones de la subtribu y con ambos marcadores, ITS y trnL-F, muestran a Loliinae como monofilético incluyendo también a Castellia Tineo en el linaje hoja fina y a Micropyropsis Romero Zarco \& Cabezudo en el linaje hoja ancha. Aquí, con un número más alto de taxones y como se podía prever en algunos de los trabajos previos, se concluye que Lolium sería monofilético, pero incluido en un clado mayor con especies del subgénero Schedonorus de Festuca; también se observa que Vulpia sería polifilético, con sus especies en diferentes subclados en el linaje hoja fina.

Catalán et al. (2007) analizan los datos moleculares previos y, aunque no aumentan el muestreo taxonómico, incorporan datos morfológicos en una filogenia combinada. Recuperan a Loliinae como monofilético, con los dos clados principales, hoja fina (que ya no presenta alto soporte) y hoja ancha, pero además con taxones de posición intermedia o ambigua: Castellia, los subgéneros de Festuca Subulatae y Leucopoa, y la sección Amphigenes. Estos grupos intermedios dan cuenta de una posible tendencia evolutiva desde el grupo más ancestral con representantes de hojas anchas hacia el grupo más reciente con representantes de hojas finas. Además, Catalán et al. (2007) plantearon que en ambos linajes principales de Loliinae (hoja ancha y hoja fina) se observa que los subgrupos basales están formados por diploides o poliploides de bajo número, mientras que los grupos más recientes parecen haber evolucionado más rápidamente y con un aumento de su ploidía, como por ejemplo los subgéneros Schedonorus (del linaje hoja ancha) y Aulaxyper (del linaje hoja fina). Este patrón de evolución se explicaría por eventos de hibridación y duplicación cromosómica. En este trabajo se propone una clasificación interna para la subtribu, reconociendo algunos géneros y secciones, pero que necesitaría ser modificada a la luz de nuevos datos.

Finalmente, en esta serie de trabajos de filogenia en la subtribu Loliinae, Inda et al. (2008) amplían el muestreo taxonómico incorporando especies de Festuca de América, Nueva Zelanda y Asia del Este, áreas que hasta el momento estaban poco representadas. Por otra parte, utilizan tres marcadores ITS, trnL-F (en anteriores trabajos) y trnT-L por primera vez. Además, incorporan representantes de los géneros Dielsiochloa Pilg. y Hellerochloa Fourn. En este análisis filogenético, Inda et al. (2008) obtuvieron nuevamente los linajes hoja ancha y hoja fina, pero se observó aumento en el número de grupos o taxones con una ubicación intermedia entre ambos linajes o con resolución ambigua. Además, encuentran taxones o linajes menores de hoja ancha que se emplazan dentro del grupo de hojas finas, como algunos del subgénero Subulatae, Leucopoa o Drymanthele. La incorporación de especies del hemisferio sur en este trabajo es 
fundamental, ya que aparecen clados (American I, American II, Asian-American, Neozeylandic I-American) que plantean una historia evolutiva de la subtribu Loliinae muy diferente a la estimada hasta entonces. Las especies americanas no solo conforman linajes propios sino que se integran en otros clados.

Inda et al. (2008) aportan fundamentalmente un enfoque de biogeografía histórica para Loliinae, estimando tiempos de divergencia para los grandes grupos de esta subtibu. Los autores estiman que Loliinae se originó en el Mioceno (13 Ma), en la región pan Mediterránea-SO de Asia, y luego probablemente se expandió hacia centro y este de Asia, desde donde colonizaron el Nuevo Mundo, coincidiendo con cambios en el clima (aumentos de aridez y frío) que aumentarían el área propicia para las pooidias tolerantes a estas nuevas condiciones (Kellogg 2001). Explicaron también que el linaje hoja ancha y el grupo Asian-American habrían radiado hace $12 \mathrm{Ma}$, mientras que el linaje hoja fina hace 10.5 Ma. Los sucesivos linajes posiblemente se originaron en el Mioceno tardío (10-5 Ma), afectados por la aparición de conexiones geográficas entre Asia y América (Tiffney 1985) y entre Europa y África (Hsü et al 1977). Los clados más recientes habrían evolucionado en el Pleistoceno (2-1 Ma) con las oscilaciones glaciares-interglaciares, forzando a las poblaciones a colonizar bajas latitudes. En este escenario surgirían los clados americanos, con una ruta migratoria predominante de Norte a Sur. También habrían ocurrido dispersiones transcontinentales a larga distancia entre Sudamérica y Nueva Zelanda. Inda et al. (2008) consideran que esta reconstrucción biogeográfica es congruente con los niveles de ploidía presentes actualmente en las especies analizadas de Loliinae: en Europa y Asia las especies nativas son diploides, en Norteamérica predominan los tetraploides y los hexa u octoploides son más frecuentes en Sudamérica.

Posteriormente, Catalán et al. (en preparación) ampliaron el muestreo taxonómico con especies africanas y definen un clado Afro-American clade o clado Afro-Americano, pero estos datos no han sido publicados.

El estudio de Inda et al. (2008) representa el mayor esfuerzo de muestreo taxonómico para un análisis filogenético en la subtribu Loliinae hasta el momento, con 130 taxones del género Festuca. Sin embargo, con respecto a especies americanas de Festuca, solo se han considerado 23 especies de Norteamérica (para un total de 45 citadas por Darbyshire et al. 2003), 2 de Mésoamérica (20 especies citadas por Davidse 1994) y 18 especies de Sudamérica, de las 220 citadas por Stančík (2003). La mayor parte de los representantes de otros géneros de Loliinae no son americanos.

La amplitud del muestreo taxonómico es un punto fundamental para obtener resultados significativos en los análisis evolutivos de cualquier grupo de organismos (Hillis \& Weins 
2000). En la serie de estudios filogenéticos en la subtribu Loliinae que se ha detallado más arriba, se observa un aumento progresivo del número de taxones analizados. Desde Torrecilla \& Catalán (2002), donde había muy pocos representantes de especies del Nuevo Mundo, hasta el trabajo de Inda et al. (2008) en el que se amplió el muestreo de especies americanas, neozelandesas y asiáticas, se observan cambios significativos en la topología de los árboles hallados y en los valores de soporte de los principales clados. Todavía, las relaciones filogenéticas de las especies americanas de Festuca han sido poco exploradas debido al bajo número de taxones muestreados y la incorporación de nuevos taxones podría cambiar la interpretación de la historia evolutiva de las Loliinae.

El objetivo de este capítulo es ampliar el muestreo de especies sudamericanas de Festuca para la filogenia molecular de la subtribu Loliinae y analizar las relaciones filogenéticas de éstas con el resto de las especies y los linajes que integran.

\section{MATERIALES Y MÉTODOS}

Selección de taxones y material de estudio

Se obtuvieron de Genbank las secuencias de los marcadores trnT-L, trnL-F e ITS publicadas por Inda et al. (2008) y trabajos allí citados.

Se bajaron 54 secuencias de los 19 taxones definidos como grupos externos por Inda et al. (2008), los cuales incluyen representantes de las subtribus Parapholiinae / Cynosurinae (8) y Dactylidinae (2), más estrechamente relacionadas a Loliinae, y representantes de las subtribus más distantes Poinae/Puccinellinae (2) y las tribus Aveneae (4), Seslerieae (1), Triticeae (1) y Brachypodieae (1). De ésta última, se usó a Brachypodium distachyon como raíz.

Se bajaron 491 secuencias de los 163 taxones de la subtribu Loliinae utilizados por Inda et al. (2008), de los cuales 130 corresponden a taxones de Festuca (de siete subgéneros y 22 secciones), 14 taxones de Vulpia (de las cinco secciones reconocidas en este género), cuatro taxones de Lolium, y taxones de otros géneros de Loliinae (Castellia, Ctenopsis, Dielsiochloa, Hellerochloa, Mycropyropsis, Micropyrum, Psilurus y Wangenheimia). Los datos de los especímenes de los cuales se obtuvieron las secuencias nucleotídicas bajadas de Genebank pueden obtenerse en Inda et al. (2008: 934-940, Tabla 1). Las secuencias registradas en Inda et al. (2008) para Festuca breviglumis Swallen y para Vulpia octoflora (Walter) Rydb. no pudieron obtenerse de la base de datos de Genebank. 
Se incorporaron 67 nuevas secuencias de 23 taxones americanos obtenidas para este trabajo en América del Sur (Festuca arundinacea Schreb. y Vulpia myuros (L.) C.C. Gmel. son nativas de Europa y África, pero se incorporaron vouchers americanos, ya que crecen como introducidas). Algunos de estos taxones están representados por más de un espécimen. La mayor parte de estos taxones (16) no habían sido muestreados en las filogenias previas y se indican con * en la Tabla 1. Estos materiales se coleccionaron en trabajos de campo realizados durante la tesis doctoral y el material de referencia se conserva en el herbario SI (Thiers 2015). En algunos casos, se obtuvieron secuencias a partir de material de herbario (LP, COL, Z), con el permiso correspondiente.

Tabla 1. Lista de especímenes de especies sudamericanas incorporadas en este trabajo a la filogenia de Loliinae de Inda et al. (2008). Se indica con x los marcadores obtenidos para cada espécimen (secuencias no publicadas).

\begin{tabular}{|c|c|c|c|c|c|}
\hline Taxones & Colector y Nro. & Procedencia & $\operatorname{trnT}-\mathrm{L}$ & $\operatorname{trnL}-F$ & ITS \\
\hline \multirow[t]{3}{*}{ estuca acanthophylla var. acanthophylla * } & Sede $341 \mathrm{a}$ & Argentina (Neuquén) & $\mathrm{x}$ & $\mathrm{x}$ & $\mathrm{x}$ \\
\hline & Ospina et al. 2010 & Chile (Chillán) & $\mathrm{x}$ & $\mathrm{x}$ & $\mathrm{x}$ \\
\hline & Zuloaga et al. 12563 & Argentina (Neuquén) & $\mathrm{x}$ & $\mathrm{x}$ & $\mathrm{x}$ \\
\hline \multirow[t]{2}{*}{ Festuca acanthophylla var. scabriuscula * } & Ospina et al. 2008 & Chile (Chillán) & $\mathrm{x}$ & $\mathrm{x}$ & $\mathrm{x}$ \\
\hline & Sede $307 a$ & Argentina (Neuquén) & $\mathrm{x}$ & $\mathrm{x}$ & $\mathrm{x}$ \\
\hline Festuca argentina & Zuloaga et al. 14151 & Argentina (Chubut) & $\mathrm{x}$ & $\mathrm{x}$ & $\mathrm{x}$ \\
\hline Festuca arundinacea & Morrone 6266 & $\begin{array}{c}\text { Argentina (Buenos } \\
\text { Aires) }\end{array}$ & $\mathrm{x}$ & $\mathrm{x}$ & $\mathrm{x}$ \\
\hline \multirow[t]{2}{*}{ Festuca asplundii $*$} & Sylvester 1700 & Perú (Cuzco) & $\mathrm{x}$ & $\mathrm{x}$ & $\mathrm{x}$ \\
\hline & Sylvester 1401 & Perú (Cuzco) & $\mathrm{x}$ & $\mathrm{x}$ & $\mathrm{x}$ \\
\hline Festuca casapaltensis * & Sylvester 1156 & Perú (Cuzco) & $\mathrm{x}$ & $\mathrm{x}$ & $\mathrm{x}$ \\
\hline Festuca chrysophylla & Zuloaga et al. 13139 & Argentina (Salta) & $\mathrm{x}$ & $\mathrm{x}$ & $\mathrm{x}$ \\
\hline Festuca cochabambana & $\begin{array}{l}\text { Wood \& Goyder } \\
\quad 17085\end{array}$ & Bolivia (Cochabamba) & $\mathrm{x}$ & $\mathrm{x}$ & $\mathrm{x}$ \\
\hline Festuca cocuyana* & Wood 5260 & Colombia (Boyacá) & & & $\mathrm{x}$ \\
\hline Festuca dissitiflora * & Zuloaga et al. 13081 & Argentina (Salta) & $\mathrm{x}$ & $\mathrm{x}$ & $\mathrm{x}$ \\
\hline \multirow[t]{2}{*}{ Festuca dolichophylla* } & Peterson et al. 12631 & Bolivia (La Paz) & $\mathrm{x}$ & & $\mathrm{x}$ \\
\hline & Sylvester 1986 & Perú (Cuzco) & & $\mathrm{x}$ & $\mathrm{x}$ \\
\hline Festuca gracillima var. gracillima $*$ & Zuloaga et al. 14090 & Argentina (Santa Cruz) & $\mathrm{x}$ & $\mathrm{x}$ & $\mathrm{x}$ \\
\hline Festuca hieronymi $*$ & Sede 483 & Argentina (San Juan) & $\mathrm{x}$ & $\mathrm{x}$ & \\
\hline Festuca kurtziana * & Sede $378 \mathrm{a}$ & Argentina (Mendoza) & $\mathrm{x}$ & $\mathrm{x}$ & $\mathrm{x}$ \\
\hline Festuca nemoralis * & Zuloaga et al. 12977 & Argentina (Salta) & $\mathrm{x}$ & $\mathrm{x}$ & \\
\hline Festuca parodiana & Sede 490 & Argentina (San Juan) & $\mathrm{x}$ & $\mathrm{x}$ & \\
\hline Festuca pallescens * & Urtubey 834 & Argentina (Chubut) & $\mathrm{x}$ & $\mathrm{x}$ & \\
\hline Festuca procera $*$ & Sylvester 1903 & Perú (Cuzco) & $\mathrm{x}$ & $\mathrm{x}$ & $\mathrm{x}$ \\
\hline Festuca purpurascens & Morrone et al. 6110 & Argentina (Neuquén) & & $\mathrm{x}$ & $\mathrm{x}$ \\
\hline Festuca roigii $*$ & Sede 427 & Argentina (Mendoza) & $\mathrm{x}$ & $\mathrm{x}$ & $\mathrm{x}$ \\
\hline Festuca soukipii * & Sylvester 1955 & Perú (Cuzco) & $\mathrm{x}$ & $\mathrm{x}$ & $\mathrm{x}$ \\
\hline Festuca subulifolia * & Ospina 2100 & Ecuador (Quito) & & $\mathrm{x}$ & $\mathrm{x}$ \\
\hline Vulpia myuros & Ospina 2007 & Chile (Chillán) & $\mathrm{x}$ & $\mathrm{x}$ & $\mathrm{x}$ \\
\hline
\end{tabular}


Los datos de ploidía o número cromosómico de cada especie que se discute en Resultados y Discusión se obtuvieron de Tropicos (www.tropicos.org) o se indica la cita correspondiente aquí o en el tratamiento taxonómico.

Extracción de ADN, amplificación y secuenciación de marcadores

Para la extracción de ADN a partir de hojas frescas secadas y conservadas en sílica-gel, se utilizó el protocolo CTAB modificado de Doyle \& Doyle (1987). Para la extracción de ADN a partir de material de herbario se siguió el Protocolo de DNeasy plant mini kit (Qiagen, Hilden, Alemania).

Las secuencias nucleotídicas correspondientes a las regiones no codificantes del cloroplasto, trnT-L y trnL-F, y a la región ITS del ADN nuclear (ITS1 + 5.8S + ITS2), se amplificaron mediante la reacción en cadena de la polimerasa (PCR). Se utilizaron los siguientes primers para amplificación y posterior secuenciación:

\begin{tabular}{cccc}
\hline Marcador & Primer & Secuencia $\left(\mathbf{5}^{\prime}-\mathbf{3}^{\prime}\right.$ ) & Fuente \\
\hline ITS & ITSL (f) & TCG TAA CAA GGT TTC CGT AGG TG & Hsiao et al. (1995) \\
& ITS 4 (r) & TCC TCC GCT TAT TGA TAT GC & Hsiao et al. (1995) \\
trnT-L & a (f) & CAT TAC AAA TGC GAT GCT CT & Taberlet et al. (1991) \\
& b (r) & TCT ACC GAT TTC GCC ATA TC & Taberlet et al. (1991) \\
trnL-F & c (f) & CGA AAT CGG TAG ACG CTA CG & Taberlet et al. (1991) \\
& d (r) & GGG GAT AGA GGG ACT TGA AC & Taberlet et al. (1991) \\
& e (f) & GGT TCA AGT CCC TCT ATC CC & Taberlet et al. (1991) \\
& f(r) & ATT TGA ACT GGT GAC ACG AG & Taberlet et al. (1991) \\
\hline
\end{tabular}

Las reacciones de PCR fueron realizadas en volúmenes finales de 25 ul, conteniendo 2-2,5 ul de suspensión del DNA templado, 1,3 ul (10mM) de cada primer, 2,5 ul de solución buffer (200 $\mathrm{mM}$ Tris pH 8.4, $500 \mathrm{mM} \mathrm{KCl}), 2,5 \mathrm{ul}(62.5 \mathrm{mM})$ de $\mathrm{MgCl} 2,0,25 \mathrm{ul}(2,5 \mathrm{mM})$ de cada dNTP (desoxi-nucleótidos trifosfato), 0,3 ul de 5 unit/ul de la enzima Taq Polimerasa recombinante provista por Invitrogen (Brazil), y el resto del volumen de agua ultra pura. En algunos casos se usó 0,1 ul $(100 \%)$ de dimetilsulfoxido (DMSO) para incrementar el rendimiento, la especificidad y la consistencia de las reacciones de PCR. Las condiciones para la amplificación fueron: un primer período de desnaturalización a $94^{\circ} \mathrm{C}$ por 5 minutos, seguido por 35 ciclos de desnaturalización a $94^{\circ} \mathrm{C}$ por 30 segundos, annealing a $53-58^{\circ} \mathrm{C}$ por 1 minuto, $72^{\circ} \mathrm{C}$ por 1 minuto; con un ciclo de extensión final de $72{ }^{\circ} \mathrm{C}$ por 6 minutos. Los productos de PCR 
obtenidos fueron corridos en un gel de agarosa $1 \%$ teñido con SYBR Safe DNA gel stain (Invitrogen) para corroborar la presencia de una única banda. Para la purificación del producto de PRC y secuenciación se solicitó el servicio de Macrogen Inc., Corea (www.macrogen.com). Se secuenciaron ambas cadenas del ADN.

Para la lectura de los cromatogramas y el ensamblado y edición de las secuencias se utilizó el programa Chromas Pro v1.49 (Technelysium Pty, Ltd). En todos los cromatogramas fue corroborada la presencia de un único pico correspondiente a cada base nucleotídica y las secuencias que presentaron múltiples picos fueron descartadas. En la Tabla 1 se indican los marcadores amplificados y secuenciados correctamente para cada espécimen.

\section{Alineamiento de las secuencias y análisis filogenéticos}

Las secuencias de ADN bajadas de Genbank y las obtenidas en este trabajo se alinearon mediante el programa ClustalW (Thompson \& al. 1994) seguido de ajustes manuales usando BioEdit 7.0.9.0 (Hall 1999) disponible en http://www.mbio.ncsu.edu/BioEdit/bioedit.html.

Se construyeron tres matrices: 1) con las secuencias nucleotídicas de los marcadores de cloroplasto (trnL-F y trnT-L) y los gaps codificados como caracteres binarios; 2) con las secuencias nucleotídicas del marcador de núcleo (ITS); 3) con datos combinados de las matrices 1 y 2. Para los taxones en los que no se logró amplificar o secuenciar alguno de los tres marcadores, se codificó en la matriz como dato faltante.

Las matrices se analizaron con métodos de máxima parsimonia (MP, Farris 1983) e inferencia Bayesiana (IB, Yang \& Rannala 1997; Huelsenbeck et al. 2002). En todos los análisis los gaps fueron tratados como datos faltantes. Se identificaron los gaps no ambiguos e informativos en los marcadores del cloroplasto y se codificaron como caracteres binarios usando el "simple indel coding" de Simmons \& Ochoterena (2000), utilizando el programa FastGap v1.1 (Borchsenius 2009). Para ITS los gaps resultaron ambiguos y se excluyeron del análisis.

En los análisis de MP, las búsquedas de árboles fueron llevas a cabo con el programa TNT v1.1. (Goloboff et al. 2008), bajo pesos iguales de los caracteres y utilizando búsquedas heurísticas con 1000 réplicas de adición de secuencias al azar (RAS, "random sequence addition"), intercambio de ramas por TBR ("tree-bisection-and-reconnection") y guardando 10 árboles por réplica; los árboles óptimos obtenidos fueron entonces sujetos a una nueva ronda de intercambio de ramas por TBR hasta encontrar las topologías más parsimoniosas. Se trabajó con memoria para guardar hasta 8000 árboles. También se realizaron búsquedas de árboles de Wagner con 
Sectorial Search y Tree fusing implementados en TNT y luego swapeados con TBR y no se hallaron árboles de menor longitud. El valor de soporte de los diferentes nodos fue estimado utilizando el índice de Bootstraps (BS, Felsenstein 1985) utilizando 2000 réplicas de 10 RAS, guardando 4 árboles por réplica, y usando la probabilidad de remoción por defecto $(\mathrm{p}=0,36)$.

En los análisis de IB, las búsquedas de árboles fueron llevas a cabo con el programa MrBayes v3.2.1 (Ronquist et al. 2012). El modelo de sustitución nucleotídica (GTR + G + I, 4 gamma) citado por Inda et al. (2008) fue utilizado para éste análisis, sin embargo, la selección de este modelo para los datos plastidiales y nucleares fue testeada utilizando el criterio de Información Akaike (AIC) (Posada \& Buckley 2004) utilizando el programa JModeltest v3.7 (Posada \& Crandall 1998), coincidiendo en los modelos. La búsqueda de árboles se realizó con dos análisis simultáneos, iniciando a partir de diferentes árboles al azar con cuatro cadenas de Markov Monte Carlo ( 3 calientes, 1 fría) ejecutados por 2 millones de generaciones y muestreados cada 1000 generaciones con el fin de asegurar la independencia de los muestreos sucesivos. La convergencia y el tamaño de muestra efectivo (ESS, efective sample size) fueron examinados usando el programa Tracer v. 1.4 (Rambaut \& Drummond 2007). Las primeras 250 muestras $(12,5 \%$ del total de las muestras) fueron descartadas como parte del proceso de "burn-in". Las muestras remanentes de cada análisis fueron combinadas y utilizadas para calcular un árbol consenso de la mayoría (\% 50), informándose la probabilidad posterior (PP) asociada a cada nodo.

\section{RESULTADOS Y DISCUSIÓN}

Descripción de los marcadores moleculares y de las matrices

Las características de los marcadores utilizados para construir las matrices analizadas en este estudio filogenético, se resume en la siguiente tabla:

\begin{tabular}{cccccc}
\hline Marcador & $\begin{array}{c}\text { Nro. de } \\
\text { secuencias } \\
\text { obtenidas }\end{array}$ & $\begin{array}{c}\text { Largo de } \\
\text { secuencias } \\
\text { alineadas }\end{array}$ & $\begin{array}{c}\text { Datos } \\
\text { faltantes } \\
(\%)\end{array}$ & $\begin{array}{c}\text { Caracteres } \\
\text { informativos }\end{array}$ & $\begin{array}{c}\text { Nro. de gaps } \\
\text { informativos }\end{array}$ \\
\hline trnT-L & 191 & $1156 \mathrm{pb}$ & 41,7 & 221 & 45 \\
trnL-F & 199 & $1305 \mathrm{pb}$ & 41,7 & 232 & 30 \\
ITS & 194 & $638 \mathrm{pb}$ & 14,9 & 300 & - \\
\hline
\end{tabular}

*Se calculó incluyendo los gaps y las porciones que no pudieron secuenciarse. 
La matriz de cloroplasto (trnT-L + trnL-F) proporcionó 528 caracteres informativos (de 2461 obtenidos): 453 son datos moleculares y 75 corresponden a los gaps codificados como caracteres binarios. Mientras que la matriz nuclear (ITS) proporcionó 300 caracteres informativos (de los 638 obtenidos).

El marcador ITS presentó mayor número de caracteres informativos en relación a cada uno de los marcadores plastidiales, en coincidencia con los estudios de Torecilla \& Catalán (2002), Catalán et al. (2004) e Inda et al. (2008). Los marcados plastidiales individualmente mostraron menor número de caracteres informativos, pero permitieron codificar gaps no ambiguos e informativos. Además, el marcador trnT-L proporcionó 5\% menos de sitios informativos que el trnL-F, pero permitió codificar mayor número de gaps.

Por último, la tercera matriz utilizada en los análisis filogenéticos de esta tesis (trnT-L + trnL-F + gaps + ITS) proporcionó un total de 828 caracteres informativos (de 3099 caracteres).

\section{Descripción y discusión de los árboles obtenidos}

Las topologías obtenidas a partir de los análisis de máxima parsimonia y a partir del análisis de inferencia bayesiana son similares cuando se comparan las mismas particiones o matrices combinadas.

Los árboles obtenidos con la matriz de secuencias del cloroplasto y los obtenidos con la matriz de ITS muestran topologías congruentes para la mayor parte de los nodos, aunque los pocos puntos de conflicto podrían deberse principalmente a que cada partición resuelve mejor una parte diferente de la topología (se entiende como conflicto cuando hay grupos incongruentes entre marcadores y estos grupos presentan alto soporte en alguno de ellos, Catalán et al. 2004). Los marcadores plastidiales representan una región más conservada con respecto al marcador ITS, que es más variable. Así, en el análisis con ITS la resolución es baja en los nodos más internos o basales de los árboles y aporta más resolución en los linajes más recientes, mientras que los marcadores plastidiales resuelven mejor las ramas más basales. Finalmente, la topología de los árboles de la matriz combinada muestra una mayor resolución que los de las matrices por separado.

La mayor parte de los conflictos entre particiones ocurre en el grupo externo y, en el grupo interno Lonliinae, para algunos taxones que se ubican en la base de otros linajes mayores (como Castellia, F. pulchella Schrad., F. subulata Tzvelev y otros). Catalán et al. (2004) e Inda et al. (2008) analizan ampliamente los conflictos entre las dos particiones por medio del test ILD 
(Farris et al. 1994), usando matrices sin los taxones conflictivos y comparando los valores de ILD de éstas con las matrices completas, obteniendo valores significativos para ambos casos. Concluyen entonces que las incongruencias pueden deberse tanto a eventos de hibridación como a deriva génica y que no es posible descartar ninguna de las dos causas. Se menciona la presencia de parálogos en secuencias de ITS en especies de Lolium y del subgénero Schedonorus de Festuca (Gaut et al. 2000), aunque Torrecilla \& Catalán (2002) lo descartan para varias muestras secuenciadas en Festuca. Por otra parte, es ampliamente aceptada la evolución concertada en ITS en la familia Poaceae (Hsiao et al. 1995, Kellog et al. 1998). Catalán et al. (2004) mencionan que las diferencias entre particiones deben tener más que ver con el muestreo finito o deriva génica y no con hibridación ya que los conflictos aparecen en la base de grupos poco soportados. Sin embargo, estos autores basan sus discusiones de la subtribu Loliinae en los análisis de las matrices combinadas ya que obtienen árboles más resueltos y los nodos conflictivos presentan, además, bajo soporte.

En esta tesis se sigue el mismo criterio de usar la matriz combinada ya que la topología encontrada permite cumplir con el objetivo de analizar las relaciones filogenéticas de la especies Sudamericanas incorporadas en el contexto de la subtribu Loliinae sensu Inda et al. (2008) y se señalan las diferencias más importantes entre los diferentes análisis.

El árbol consenso de todos los árboles muestreados en el análisis bayesiano a partir de la matriz combinada se ilustra en las Figuras 1 y 2 (al final de este capítulo). En el análisis de máxima parsimonia con la matriz combinada se obtuvieron 8000 árboles de menor longitud (máximo espacio en la memoria), con 2152 pasos. El consenso estricto de los árboles obtenidos con el análisis de máxima parsimonia se resume en la Figura 3.

La incorporación de las 67 secuencias de las 23 especies Sudamericanas no modifica la estructura general de la filogenia de la subtribu Loliinae, aunque en este análisis algunos grupos se ubican de manera diferente con respecto a Inda et al. (2008).

A continuación se describen los grupos o clados (se usan de manera indistinta) recuperados en este trabajo, en los análisis de IB y de MP, se indican los valores de Probabilidad Posterior (PP) y los valores de Bootstrap (BS). Se señalan las diferencias, si existen, con respecto a la hipótesis de Inda et al. (2008) para los clados más importantes:

- Subtribu Loliinae (1 PP, 83 BS). Se corrobora la monofilia de la subtribu Loliinae. Se mantiene la división de los dos linajes de la subtribu: hoja ancha y hoja fina, pero con diferente ubicación del clado Asian-American. 
- Linaje hoja ancha (1 PP, 68 BS). Este grupo incluye los mismos subclados definidos en Inda et al. (2008): Lojaconoa, Drymanthele s.s. + Scariosae + Pseudoscariosa, Leucopoa, Subulbosae, 'Maghrebian' Schedonorus y 'European' Schedonorus (con las especies de Lolium incluidas en este último). En este trabajo se incorporó una secuencia de F. arundinacea de Argentina (introducida en América), y ésta se ubica como hermana del voucher de $F$. arundinacea var. arundinacea europeo (España) muestreado por Inda et al. (2008), y que se ubicó en el subclado 'European' Schedonorus (Figura 1 a).

- Linaje Asian-American (1 PP, 70 BS). En el análisis de IB aquí presentado, este linaje se ubica como hermano del linaje hojas finas (con bajo soporte), pero en el análisis de MP (Figura 3), el Asian-American es hermano a las especies de hoja ancha, en una rama de bajo soporte (BS 68). Inda et al. (2008) obtienen el grupo hoja ancha + AsianAmerican aunque sin soporte. En los análisis con ITS (MP e IB) las especies de este grupo se emplazan con F. pulchela Schrad., F. altaica Trin. y F. subulata, especies de ubicación ambigua en el clado hojas finas. En este linaje se ubica la especie $F$. argentina (Speg.) Parodi (Chubut, Argentina) incluida en esta tesis y que se ubica junto al voucher del mismo taxón (proveniente de Santa Cruz, Argentina) incluido previamente por Inda et al. (2008) (Figura 1 b). La secuencia de Festuca breviglumis (Inda et al. 2008) no pudo obtenerse.

- Linaje hoja fina (0,62 PP, $57 \mathrm{BS})$. Este grupo es recuperado en los análisis de IB y MP, pero su soporte es bajo y no se resuelven los nodos basales. En la topología de Inda et al. (2008) existen las mismas politomías o nodos sin soporte aunque se resuelven algunos grupos menores nombrados como "especies intermedias" u "hojas finas basales". En el análisis de MP (Figura 3) el clado Neozeylandic I-American se ubica de manera más basal que el resto de las especies de hoja fina (igual que $F$. pulchela).

En las Figuras 1 y 2 se observa que en la base del grupo hojas finas se ubican las variedades de la especie $F$. pulchela (Amphigenes s.s., en Inda et al. 2008) y luego una politomía con los siguientes taxones o grupos monofiléticos:

\section{Castellia tuberculosa}

\section{Festuca burnatii}

3. Festuca altaica + F. subulata $(0,99 \mathrm{PP})$ 
Estos tres no presentan una posición determinada en ningún clado (politomía). En Inda et al. (2008) estos taxones se ubican en la base del clado hojas finas, en los subclados "especies intermedias" y hojas finas basales. Una resolución similar se obtiene en el árbol de máxima parsimonia, aunque $F$. altaica Trin. y $F$. subulata se reúne con especies de la sección Eskia (Figura 3).

\section{Festuca clementei + Micropyrum tenellum + M. patens (0,56 PP).}

En el análisis de MP no se recupera este grupo y en Inda et al. (2008) estas especies se ubican dentro del clado hojas finas propiamente dicho.

5. Eskia (F. elegans + F. eskia + F. gautieri, $70 \mathrm{PP})$

Este grupo presenta parte de las especies de la sección Eskia. En el análisis con máxima parsimonia parte de las especies de la sección Eskia se relacionan con F. altaica y $F$. subulata y parte con la sección Dimorpha.

\section{American Vulpia (1 PP, $97 \mathrm{BS})$.}

Este grupo en la filogenia de Inda et al. (2008) se ubica dentro del clado hojas finas propiamente dicho. Aquí se ubicaron las especies $F$. nemoralis Türpe y $F$. roigii Dubcovs. \& Rúgolo, sumadas en este análisis, junto a Vulpia microstachys (Nutt.) Munro (Figura 1 c). No fue posible obtener la secuencia de la especie $V$. octoflora (incluida en este grupo en Inda et al. 2008). En los análisis con ITS estas especies se emplazan con representantes del grupo Neozeylandic I-American.

\section{Neozeylandic I-American (1 PP, 99 BS)}

Aquí se ubica $F$. gracillima var. gracillima Hook. f., incorporada en este trabajo (Figura 1 d). Este grupo tiene una posición más basal en el árbol de MP, como se mencionó anteriormente; es referido como grupo hojas finas basales por Inda et al. (2008).

\section{Eskia-Dimorpha (0,95 PP).}

Este grupo reúne especies de las secciones Eskia y Dimorpha. En Inda et al. (2008) se ubica entre el grupo hojas finas basales.

\section{American I (0,99 PP).}

En Inda et al. (2008) este clado, con muy pocos representantes (seis especies americanas), presentó alto soporte y aparece como grupo hermano de las restantes especies del grupo hoja 
fina. Aquí se recupera el clado, también con alto soporte, en el análisis de IB, pero sin valor de bootstrap en el análisis de MP. Sin embargo, en coincidencia con Inda et al. (2008), los análisis con ITS solamente, muestran un clado con las especies del American I y del American II mezcladas en una extensa politomía. En este trabajo se amplía el grupo American I con la incorporación de diez secuencias de seis especies sudamericanas (Figura 1 e). El grupo American I queda dividido en dos subgrupos monofiléticos: especies con distribución en los Andes del norte de Sudamérica (Festuca chimborazensis E.B. Alexeev, F. glumosa Hack. ex E.B. Alexeev, F. cocuyana Stančík, F. vaginalis (Benth.) Lægaard y F. edlundiae S.G. Aiken, L.L. Consaul \& Lefk.) y especies con distribución más austral (F. acanthophylla var. acanthophylla É. Desv., F acanthophylla var. scabriuscula J.C. Ospina, Aliscioni \& S. Denham, F. subantarctica Parodi, F. pallescens (St.Yves) Parodi, F. purpurascens Banks \& Sol. ex Hook. f., F. parodiana (St.-Yves) Nicora y F. kurtziana St.-Yves).

10. Hoja fina propiamente dicho (restantes especies hoja fina, $0,5 \mathrm{PP}$ ).

Este clado con muy bajo soporte también está presente en la filogenia de Inda et al. (2008), con algunas variantes ya mencionadas. En este clado se recuperan los subclados: Psilurus/Vulpia (1 PP), Loretia/Ctenopsis + Exaratae (0,69 PP), Wangenheimia + Festuca (grupo Festuca ovina, 100 PP), American II (79 PP), Vulpia (2x) (98 PP) y Aulaxyper (grupo F. rubra, 0,68 PP). En ambas filogenias (Inda et al. 2008 y este análisis) los clados American II y Aulaxyper + Vulpia (2x) aparecen más estrechamente relacionados entre sí que con los restantes. En la base del grupo American II + Aulaxyper + Vulpia (2x) se ubicaron F. parvigluma Steud. y F. rifana Litard. \& Maire. En el análisis de MP no se recupera este grupo hoja fina propiamente dicho, pero si los subclados mencionados y el grupo monofilético American II + Aulaxyper + Vulpia (2x) (ver Figura 3). Ya se mencionó que con la matriz de ITS se recupera un grupo con especies de American I y American II. En el grupo American II se ubicaron nueve taxones muestreados en este trabajo ( $F$. asplundii E.B. Alexeev, F. casapaltensis Ball, F. cochabambana E.B. Alexeev, F. dissitiflora Steud. ex Griseb., F. dolichophylla J. Presl, F. hieronymi Hack., F. procera Kunth, F. soukupii Stančík y F. chrysophylla Phil.). En el subgrupo Vulpia (2x) se ubicó F. subulifolia Benth.

$\underline{\text { Análisis de las relaciones filogenéticas de las especies americanas de Festuca }}$

De los 23 taxones americanos incorporados a la filogenia de la subtribu Loliinae en este trabajo, 16 no habían sido previamente considerados en las filogenias publicadas de las Loliinae. Esta nueva información permite estimar que las especies sudamericanas de Festuca se originaron a 
partir de diferentes linajes y permite también ampliar el conocimiento de los grupos AsianAmerican, American Vulpia, Neozeylandic I/American, American I, American II y Vulpia (2x).

Siete taxones ya estaban incluidos en el trabajo de Inda et al. (2008) o trabajos previos allí citados: F. argentina, F. arundinacea, F. chrysophylla (como F. orthophylla Pilg.), F. cochabambana, F. purpurascens y Vulpia myuros, y se confirma su posición en los mismos clados. Excepto $F$. parodiana, que en este estudio presenta una ubicación diferente. No fue posible analizar el ejemplar de referencia del voucher de $F$. parodiana usado por Inda et al. (2008) y no se descarta una determinación errónea.

A continuación se comentan las relaciones filogenéticas de las especies incorporadas en este trabajo. Para los comentarios sobre la clasificación infragenérica de los taxones se usó la más difundida para Festuca s.1., que es la de Clayton \& Renvoize (1986), seguida por la mayoría de los autores y usada por Müller \& Catalán (2006) e Inda et al. (2008).

\section{- Linaje hoja ancha, 'European' Schedonorus: Festuca arundinacea (Figura 1a)}

Se confirma la posición de $F$. arundinacea en el linaje ‘European' Schedonorus. Esta especie es originaria de Europa, mientras que el ejemplar aquí incorporado proviene de una población introducida en Argentina y se ubica como taxón hermano del voucher europeo de la misma especie. El grupo Schedonorus es reconocido como un subgénero de Festuca (Clayton \& Renvoize 1986, Müller \& Catalán 2006, Inda et al. 2008) o ha sido tratado como género Schedonorus (Darbyshire 2007) o incluso F. arundinacea ha sido considerada como especie de Lolium (Darbyshire 1993). Las especies del clado 'European' Schedonorus están más relacionadas con el origen de Lolium que con el grupo africano de Schedonorus ('Maghrebian' Schedonorus) o que con las restantes especies del clado hoja ancha.

Festuca arundinacea es un hexaploide $(2 \mathrm{n}=42)$ y en el grupo Schedonorus europeo hay también representantes diploides o tetraploides.

El análisis realizado sobre los caracteres de anatomía y micromorfología foliar permitió asignar a $F$. arundinacea dentro del tipo A, correspondiente al patrón comúnmente llamado "hoja ancha". Dentro de este clado también fueron estudiadas la anatomía y/o micromorfología de $F$. gigantea (L.) Vill. (Zarinkamar \& Jouyandeh 2011; Dani et al. 2014), F. pratensis Huds. (Ortuñez \& de la Fuente 2010; Dani et al. 2014), F. apennina De Not. (Dani et al. 2014) y F. fenas Lag. (Ortuñez \& de la Fuente 2010), las cuales presentan un patrón semejante al observado en los ejemplares de F. arundinacea aquí estudiados. Asimismo, Aiken et al. (1977) realizaron un análisis fenético con datos anatómicos incluyendo a $F$. arundinacea, $F$ pratensis y F. gigantea, y muestran que las tres especies se reúnen en el mismo cluster. 


\section{- Linaje Asian-American: Festuca argentina (Figura 1b)}

Se confirma la posición de $F$. argentina en el clado Asian-American. El ejemplar de la provincia argentina de Santa Cruz de la filogenia de Loliinae de Inda et al. (2008) y el ejemplar aquí muestreado de Chubut se ubican juntos. Este clado presenta una ubicación ambigua, como se mencionó antes, más cercano al linaje hojas anchas (MP, Figura 3) o más cercano al linaje hojas finas (IB, Figura 1 y 2). La ubicación ambigua de este clado estaría relacionada con el bajo soporte del linaje hoja fina en el análisis de IB (68 PP).

Festuca argentina y $F$. dichoclada Pilg. son consideradas incertae sedis, mientras que las restantes dos especies, F. amplissima Rupr. y F. modesta Nees ex Steud., del Asian American, pertenecen al subgénero Drymanthele. Sin embargo, las restantes especies del subgénero Drymanthele se ubican en el linaje de hoja ancha. Festuca breviglumis (secuencia no analizada) pertenece al subgénero Subulatae. Estos subgéneros necesitan ser revisados en función de las relaciones filogenéticas de sus especies.

El Asian American incluye una especie diploide de Asia, F. modesta, y las restantes son especies americanas, que crecen en México-Venezuela ( $F$. amplissima), en Ecuador y Perú $(F$. dichoclada Pilg.) y en Argentina ( $F$. argentina). Las especies americanas son tetraploides. En este clado se observa el patrón de distribución histórica de especies diploides nativas de Asia y luego especies poliploides americanas; en este caso, especies tetraploides desde Mesoamérica a Sudamérica.

En este estudio, Festuca argentina es ubicada, por su patrón anatómico y micromorfológico foliar, en el grupo B2, que corresponde a un subtipo dentro de los comúnmente denominados "hoja fina", aunque en el clado Asian-American se relaciona con especies clasificadas en el subgénero de hoja ancha Drymanthele. La especie hermana, F. amplissima, fue estudiada por Stančík \& Peterson (2007), quienes muestran que sus láminas foliares son más anchas y abiertas aunque mencionan que también pueden ser algo involutas. Sin embargo, comparten con $F$. argentina la presencia de haces vasculares con trabas abaxiales y adaxiales de esclérenquima bien estructuradas. En este caso se observa que la caracterización en "hoja fina" u "hoja ancha" presenta matices y no puede establecerse desde una observación externa de la lámina. Por ejemplo, la ausencia de anillo esclerenquimático continuo posibilitaría cierto grado de plegamiento o expansión de la lámina, cambiando su aspecto según las condiciones ambientales. Esto podría ser el caso de $F$. argentina y $F$. amplissima, especies que podrían interpretarse como "hoja fina" u "hoja ancha" según su estado.

Por otro lado, Dubcovsky \& Martínez (1988) realizan un estudio fenético con caracteres anatómicos y morfológicos de las especies de Festuca de la Patagonia, donde ilustran el 
transcorte foliar de $F$. argentina, el cual coincide totalmente con el aquí se observó. Además, estos autores delimitan grupos de especies, pero concluyen que $F$. argentina, dada la combinación particular de características anatómicas que presenta, no puede incluirse en ninguno de ellos.

\section{- Linaje American Vulpia: Festuca roigii y F. nemoralis (Figura 1c)}

En la filogenia de Loliinae, las especies de Vulpia aparecen todas en el clado de hojas finas, pero segregadas en distintos subgrupos: el grupo Loretia+Ctenopsis con representantes diploides del Viejo Mundo; el grupo de especies polipliodes en el clado Psilurus/Vulpia; el clado American Vulpia; y el clado Vulpia (2x). En este trabajo se suman al clado American Vulpia dos especies poliploides sudamericanas de Festuca (F. nemoralis y F. roigii) que no habían sido muestreadas en trabajos previos.

Inda et al. (2008) muestran al grupo bien soportado American Vulpia formado por $V$. octoflora $+V$. microstachys. La secuencia de la primer especie no pudo ser incluida en el análisis aquí presentado y el grupo American Vulpia (1 PP, $95 \mathrm{BS}$ ) quedó conformado por $V$. microstachys + (F. nemoralis $+F$. roigii). Estas especies de Festuca no tienen afinidad morfológica con Vulpia, ni entre ellas. Festuca nemoralis es una especie octoploide $(2 \mathrm{n}=56)$, robusta, rizomatosa, con lígulas largas y laminas planas hasta de $5 \mathrm{~mm}$ de ancho, crece en Argentina, Paraguay y Uruguay; $F$. roigii es un tetraploide $(2 \mathrm{n}=28)$ que presenta plantas cespitosas, medianas, lígulas muy cortas y láminas convolutas, circinadas, de hasta $1 \mathrm{~mm}$ de ancho, es endémica de Mendoza. Las dos especies de Vulpia de este clado son anuales, de porte mediano, con lígulas cortas y láminas convolutas o planas, de hasta $1 \mathrm{~mm}$ de ancho, crecen en Estados Unidos de Norte América; $V$. octoflora es diploide $(2 \mathrm{n}=14)$ y $V$. microstachys hexaploide $(2 \mathrm{n}=42)$. Tampoco se observa afinidad desde el punto de vista anatómico. Festuca roigii se corresponde con el tipo anatómico y micromorfológico foliar B3 (subtipo de los comúnmente denominados "hoja fina") y su especie hermana, F. nemoralis, contrariamente, se corresponde con el tipo A (comúnmente denominados "hoja ancha").

Sin embargo, este clado presenta una señal biogeográfica observada en otras partes de la filogenia: el patrón de colonización desde América del Norte hacia Sudamérica, con la especie diploide en América del Norte y niveles de ploidía más altos en América del Sur.

En la topología hallada con el marcador nuclear ITS, F. roigii y $V$. microstachys aparecen en el mismo clado ( $\sin$ secuencias de ITS para $F$. nemoralis y $V$. octoflora). Eventos de reticulación podrían estar enmascarando las relaciones filogenéticas de estas especies, considerando que se conoce que $F$. roigii es alopoliploide (Dubcovsky \& Rúgolo 1990). 


\section{- Linaje Neozeylandic I-American: Festuca gracillima (Figura 1d)}

Esta especie no había sido previamente muestreada en ningún análisis filogenético. Festuca gracillima crece en el extremo austral de Sudamérica, en la Región XII de Chile y, en Argentina, en Santa Cruz y Tierra del Fuego. Es una especie hexaploide con 2n $=42$.

El clado Neozeylandic I-American, en el que se ubica $F$. gracillima, contiene las especies neozelandesas incertae sedis F. madida Connor, F. matthewsii (Hack.) Cheeseman, F. actae Connor, $F$. novae-zelandiae y $F$. deflexa Connor, todas ellas hexaploides. Con ubicación basal con respecto a las anteriores se emplaza $F$. califórnica Vasey $(4 \mathrm{x}, 8 \mathrm{x})$, de América del Norte, clasificada en el subgénero Leucopoa, sección Breviaristae.

Las demás especies neozelandesas de Festuca son octoploides y se ubican en el grupo Aulaxyper de hoja fina, mientras que las restantes especies de Leucopoa pertenecen al linaje hoja ancha o se ubican en la base del clado hoja fina. Este subgénero debe ser revisado.

El grupo Neozeylandic I-American está bien soportado pero la distribución geográfica de sus especies es compleja. Inda et al. (2008) mencionan que este clado podría tener su origen en un ancestro diploide del subgénero Leucopoa que colonizó América del Norte desde Eurasia y que la posterior colonización a Nueva Zelanda ocurrió desde Sudamérica a partir de taxones poliploides. Si bien hay evidencias de distribuciones desde América del Norte a Sudamérica y luego dispersión transoceánica a Nueva Zelanda (Soreng 1990, Takhtajan 1986), este clado no presentaba ningún representante sudamericano que conectase a la especie norteamericana $F$. californica con las especies neozelandesas. En este trabajo se documenta la posición de la especie sudamericana $F$. gracillima en el clado Neozeylandic I-American, confirmando este patrón de distribución. Este hallazgo apoya la hipótesis de que los poliploides de Nueva Zelanda se originaron a partir de polipliodes sudamericanos y no de diplodes asiáticos, como había sido mencionado anteriormente para especies de Poa con la misma distribución (Soreng 1990). Lloyd et al. (2007) analizan las especies neozelandesas de Festuca y obtienen este mismo grupo de especies en un clado, con la incorporación de $F$. contracta Kirk, especie hexaploide, originaria de Nueva Zelanda y que crece también en Tierra del Fuego e islas subantárticas y Australia.

En concordancia con lo anterior, en este clado la anatomía es homogénea entre las especies neozelandesas y sudamericanas, mientras que difiere de la especie del hemisferio norte. Festuca gracillima presenta el patrón anatómico y micromorfológico foliar B3 (las dos variedades). Por otra parte, F. contracta, ubicada en este grupo de acuerdo a Lloyd et al. (2007), presenta iguales caracteres anatómicos y micromorfológicos foliares que $F$. gracillima y también fue asignada en el tipo B3. La anatomía foliar de Festuca novae-zelandiae (Abernethy et al. 1998) es 
coincidente con la de F. gracillima. Asimismo, Connor (1998) muestra especímenes de herbario de $F$. actae y $F$. matthewsii con esquemas de transcortes foliares, con igual anatomía. La anatomía foliar de F. californica fue estudiada por Aiken \& Consaul (1995); se observa que difiere de las restantes especies del clado por la presencia de un anillo abaxial continuo de esclerénquima, carácter que la ubicaría dentro del tipo B1.

\section{- Linaje American I (Figura 1e)}

En la filogenia de Inda et al. (2008) este clado estaba solo representado por seis especies americanas. En este trabajo se amplia a doce los taxones que integran este clado con alto soporte (0,99 P), con la incorporación de F. acanthophylla var. acanthophylla, F. acanthophylla var. scabriuscula, F. cocuyana, F. pallescens, F. parodiana y F. kurtziana. En coincidencia con Inda et al. (2008), los análisis con ITS solamente, muestran un clado con las especies del American I y del American II mezcladas en una extensa politomía.

Los resultados obtenidos en este trabajo permiten evidenciar una fuerte estructura en el clado American I, ya que éste se subdivide en un grupo de especies tetraploides andinas, que crecen en el norte de la cordillera de los Andes (Colombia y Ecuador), y en un segundo subclado de especies hexaploides, que crecen más al sur, en Argentina, Bolivia y Chile. Inda et al. (2008) llamaron a estos subclados: andino y patagónico; sin embargo, el incremento de especies sudamericanas ahora representadas permite caracterizar mejor a estos dos subgrupos. En el llamado grupo "patagónico" se incorporaron especies con distribución patagónica y andina, pero con un límite septentrional en la Región II de Chile y en el sur de Bolivia $\left(20^{\circ} \mathrm{S}\right.$ aproximadamente). Se menciona ahora como subclado andino patagónico austral.

En el primer subgrupo (0,99 PP), el Andino, se ubica $F$. cocuyana, incorporada por primera vez a una filogenia, junto a las especies incertae sedis: F. vaginalis, F. chimborazensis, F. glumosa y junto a $F$. edlundiae del subgénero Festuca sección Festuca (típicamente de hoja fina). Todas las especies de este subclado son $2 \mathrm{n}=28$, aunque no hay datos para $F$. cocuyana. Estas especies crecen en Colombia y Ecuador, pero $F$. edlundiae es originaria de regiones árticas en Rusia, Alaska y Canadá, evocando nuevamente el patrón de distribución histórica de Eurasia hacia América.

Las especies de este subclado, además, presentan rasgos anatómicos foliares muy similares, conformando un grupo homogéneo en este aspecto. Festuca cocuyana (Stančík 2003, Ortuñez \& Cano-Ruiz 2013), F. edlundiae (Dallwitz 1980), F. glumosa (Stančík 2003), F. vaginalis y $F$ chimborazensis (observación personal sobre los ejemplares Laegaard 51386 y Peterson 8995 respectivamente) presentan transcortes conduplicados, generalmente en forma de "V", con pocos haces vasculares (5-11) y el tejido esclerenquimático se dispone interrumpido formando 
casquetes abaxiales, en algunos casos también adaxiales, y presentan macropelos en la superficie adaxial. Tomando en cuenta estas características, estas especies pertenecerían al tipo B3 establecido en el análisis de cluster.

El segundo subgrupo (0,88 PP), el andino patagónico austral, contiene a las especies $F$. acanthophylla, F. subantarctica, F. pallescens, F. purpurascens, F. parodiana y $F$. kurtziana. Todas las especies presentan un número cromosómico $2 \mathrm{n}=42$, pero no se registran datos para $F$. parodiana. Aquí se observa nuevamente que las especies de mayor ploidía en América (especies andino patagónicas australes) presentan como grupo hermano a especies de menor ploidía, que habitan más al norte en el continente (especies andinas $+F$. edlundiae).

La mayor parte de las especies del clado andino patagónico austral son incertae sedis, pero $F$. parodiana pertenece al subgénero Subulatae sección Subulatae, mientras que $F$. purpurascens se clasifica en el subgénero Drymanthele sección Banksia. Estos subgéneros presentan típicamente especies de hoja ancha. La anatomía de las especies de este subclado fue estudiada en detalle en este trabajo (Capítulo de anatomía) y se observó que difieren anatómicamente ya que les corresponde diferentes tipos anatómicos y micromorfológicos foliares. Así, $F$. parodiana y $F$. purpurascens (que integran un subgrupo monofilético) presentan el tipo A (comúnmente llamado "hoja ancha"); F. pallescens y F. kurtziana presenta el tipo B3 (un subtipo de los comúnmente llamados "hoja fina"); y las restantes especies (F. acanthophylla var. acanthophylla, F. acanthopylla var. scabriuscula, F. subantarctica) presentan el subtipo B1 (del tipo "hoja fina").

El ejemplar Sede 341 de F. acanthophylla var. acanthophylla se mantiene separado de los restantes vouchers de la misma especie (y variedades) en todos los análisis de particiones y matriz combinada. Probablemente, represente una variante molecular sin caracteres morfológicos detectables.

\section{- Linaje Psilurus + Vulpia: Vulpia myuros (Figura 1f)}

Vulpia myuros se ubica en al clado Psilurus + Vulpia (Figura 1 f) y el voucher aquí secuenciado confirma la posición obtenida por Inda et al. (2008). Este grupo presenta especies nativas de Europa y Norte de África y las especies de Vulpia crecen también en América. Psilurus incurvus (Gouan) Schinz \& Thell. es un tetraploide mientras que las especies de Vulpia son diploides hasta hexaploides. Vulpia myuros se considera adventicia naturalizada en Sudamérica (Stace 2012). 


\section{- Linaje American II (Figura 1g)}

El grupo American II estaba representado por 18 especies (Inda et al. 2008) y siete nuevos taxones muestreados en este trabajo se emplazaron en él. Además, se confirmó la ubicación de $F$. chrysophylla y $F$. cochabambana. La especie $F$. parodiana se ubica en este linaje en el trabajo de Inda et al. (2008); sin embargo, el voucher de la misma especie incorporado en este trabajo se ubica en el clado American I. Se confirmó la determinación del ejemplar de referencia aquí usado, pero no se tuvo acceso al material de referencia de Inda et al. (2008), por lo tanto se trata a esta especie como en el grupo American I.

Este grupo presenta especies americanas, principalmente sudamericanas (solo F arizonica Vasey y F. calligera (Piper) Rydb. crecen en América del Norte), y la mayor parte de ellas son hexaploides, aunque se registraron tetraploides en F. procera, F. flacca Hack. ex E.B. Alexeev, F. calligera, F. soukupii y F. andicola Kunth.

En este clado, emplazado entre las festucas de hoja fina propiamente dicho, se ubican representantes de grupos diversos, como especies de Hellerochloa Rauschert y Dielsiochloa Pilg., además de las especies clasificadas en el subgénero Subulatae de hoja ancha (sección Subulatae: F. flacca, F. cuzcoensis, F. cochabambana y F. ulochaeta Nees ex Steud.) y $F$. elviae B. Briceño, una especie incertae sedis de hoja ancha. Las restantes especies pertenecen al subgénero Festuca de hoja fina (sección Festuca: F. asplundii y F. calligera; sección Aulaxyper: F. andicola) o a especies incertae sedis de hoja fina.

Este grupo es morfológicamente diverso y no se observan caracteres que permitan separar a estas especies de las especies del grupo American I. Sin embargo, en este grupo no hay especies patagónicas, el conjunto de las especies tiene como límite más austral las provincias de Córdoba y La Rioja, aproximadamente el paralelo $32^{\circ} \mathrm{S}$, y desde allí por la cordillera de Los Andes de Chile, Bolivia, Perú, Ecuador, Colombia y Venezuela, también hay especies que crecen en Centro América, México y Estados Unidos. A diferencia de las especies andinas del clado American I, que son tetraploides, entre las especies andinas del American II predominan las hexaploides.

Con respecto al origen de este linaje, Inda et al. (2008) plantean el escenario de un ancestro europeo del grupo hermano Aulaxyper. Estiman que la evolución de estos dos grupos (Vulpia $(2 \mathrm{x})+F$. subulifolia) pudo haber sido muy rápida debido a caracteres vegetativos, como por ejemplo el hábito rizomatoso, sumado al vigor de las especies polipliodes, tan característico del grupo Aulaxyper. Esto explicaría también el bajo soporte de las ramas basales a estos grupos y la falta de resolución interna en el American II. Cabe analizar también, que en los análisis con ITS las especies de American I y American II aparecen juntas. Es posible que eventos de 
hibridación y duplicación cromosómica, como así también tasas de evolución rápidas o deriva génica sean muy frecuentes en estas especies americanas, y estos eventos estarían interfiriendo en la obtención de una hipótesis filogenética confiable.

En el grupo American II se observa que las relaciones entre las especies no están bien resueltas, hay una importante politomía en su base y se observan solo algunos grupos, de pocas especies, resueltos. Los distintos vouchers de la misma especie no siempre aparecen juntos.

En cuanto a la anatomía foliar, en clado American II es sumamente diverso, ya que en él se reúnen especies con todos los tipos foliares definidos en este trabajo (A, B1, B2 y B3). Para $F$. flacca, especie hermana a todo el clado, no hay observaciones hasta la fecha sobre su anatomía foliar, pero si para las restantes especies, donde se observa cierta congruencia anatómica entre las especies que conforman los pocos subclados de la filogenia.

La anatomía foliar de $F$. arizonica y $F$. calligera, especies hermanas en la filogenia, fue estudiada por Aiken \& Consaul (1995) y, sobre la base de los esquemas que dichos autores muestran, ambas especies podrían estar incluidas dentro del tipo B3.

El transcorte foliar de F. asplundii fue descrito por Stančík \& Peterson (2007) y correspondería al subtipo B1 por la presencia de anillo abaxial esclerenquimático continuo, pero se destaca por poseer abundantes asperezas en la epidermis abaxial (observación personal sobre el ejemplar Sylvester 1401); la especie hermana, F. casapaltensis sería semejante pero carece de asperazas abundantes (observación personal sobre el ejemplar Sylvester 1156).

Festuca ulochaeta corresponde con el tipo A, coincidentemente con su especie hermana en la filogenia, F. cochabambana que presenta un transcorte expandido con numerosos haces vasculares y con plegamiento del tipo involuto (observación personal sobre el ejemplar Wood \& Goyder 10217). Iguales características se observaron en F. hieronymi, especie cuya anatomía se estudió y también se le asignó el tipo foliar A.

Festuca dissitflora y F. yalaensis Joch. Müll. \& Catalán, ambas pertenecen al subtipo B2; $F$. chrysophylla al subtipo B1 y $F$. nardifolia Griseb. al B3; F. dolichophylla pertenece al mismo subclado que las anteriores y su anatomía podría ser semejante al subtipo B3 con numerosas asperezas abaxiales (observación personal sobre el ejemplar Peterson et al. 12631).

Las láminas de $F$. soukupii y $F$. andicola fueron esquematizadas por Stančík (2003), y $F$. elviae por Stančík y Peterson (2007); F. soukupii y F. elviae, corresponderían al subtipo B2. En relación a $F$. andicola, Stančík (2003) esquematiza 3 ejemplares con algunas diferencias 
anatómicas (serían B2 y B3), por lo que esta especie resulta variable a nivel de la anatomía foliar.

Tovar (1972) muestra un transcorte de Festuca longivaginata Tovar, el cual es abierto, semejante al tipo foliar A, y se relaciona filogenéticamente con F. rigescens (J. Prels) Kunth cuya anatomía no coincide por ser del subtipo B3.

Dentro del clado American II también se incluyen $F$. procera, $F$. tolucensis Kunth, las que podrían pertenecer al subtipo B1 por presentar anillo continuo abaxial de esclerénquima según los esquemas de Stančík (2003); también F. cundinamarcae E.B. Alexeev y F. cuzcoensis Stančík \& P.M. Peterson anatómicamente muy semejantes con haces trabados por tejido esclerenquimático (Stančík 2003; observación personal sobre el ejemplar Treviño 195).

\section{- Linaje Vulpia (2x): Festuca subulifolia (Figura 1h)}

Festuca subulifolia es una especie tetraploide $(2 \mathrm{n}=28)$ que crece en Colombia, Perú, Ecuador y Bolivia. Morfológicamente se asemeja a $F$. dolichophylla con quien comparte el área de distribución y que se ubica en el clado American II. Festuca subulifolia no había sido incorporada anteriormente a ningún análisis filogenético y en este estudio se ubica junto a dos especies europeas del género Vulpia: Vulpia bromoides (L.) Gray, especie diploide $(2 \mathrm{n}=14)$, nativa de Europa, África del Norte y Asia Menor, introducida en América donde crece desde Canadá a Argentina; y a Vulpia muralis (Kunth) Nees, diploide $(2 \mathrm{n}=14$, aunque también hay registros $n=14, n=21$, Bailey \& Stace 1984; Spies et al. 1997, 1999), nativa de Europa, e introducida en Sudamérica (Venezuela a Chile). Sin embargo, esta relación de F. subulifolia con las especies del clado Vulpia (2x) no se observa en todos los análisis; se obtiene con la matriz combinada (IB) y con la matriz de ITS (IB y MP). Cuando se analizó la matriz combinada con máxima parsimonia o la matriz de cloroplasto (IB y MP), $V$. bromoides $+V$. muralis se ubican entre las especies de grupo Aulaxyper, mientras que $F$. subulifolia queda en una politomía junto a las especies del grupo American II (Figura 3). Este conflicto entre las matrices de secuencias del cloroplasto y del núcleo podría deberse a un origen híbrido de F. subulifolia. Por otra parte, Torrecilla et al. (2004) mostraron que los linajes de especies anuales, como son las especies de Vulpia, tienen tasas de sustitución nucleotídicas muy altas y que las secuencias de ITS podrían tener muchos caracteres homoplásicos. Es necesario continuar con los estudios en las especies de Vulpia en América.

La anatomía foliar de F. subulifolia fue esquematizada y descripta por Stančík (2003) y coincidiría con el tipo B1. 


\section{FIGURAS}

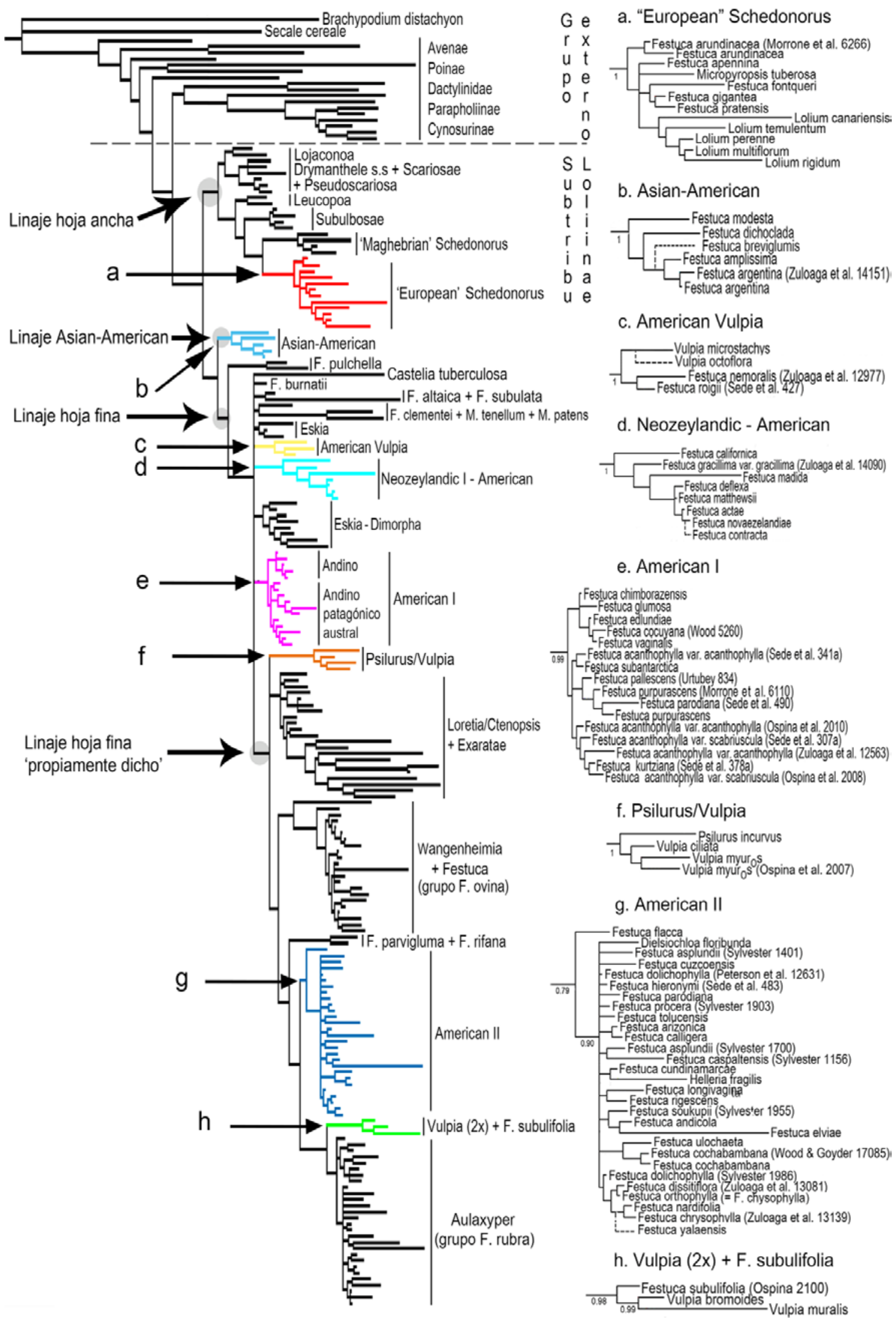

Figura 1. Esquema del árbol de inferencia bayesiana (consenso de mayoría) de la subtribu Loliinae obtenido a partir de la matriz combinada (trnT-L + trnL-F + gaps + ITS) de la Figura 2. A la derecha, detalle de los grupos con especies sudamericanas y los respectivos valores de probabilidad posterior. 


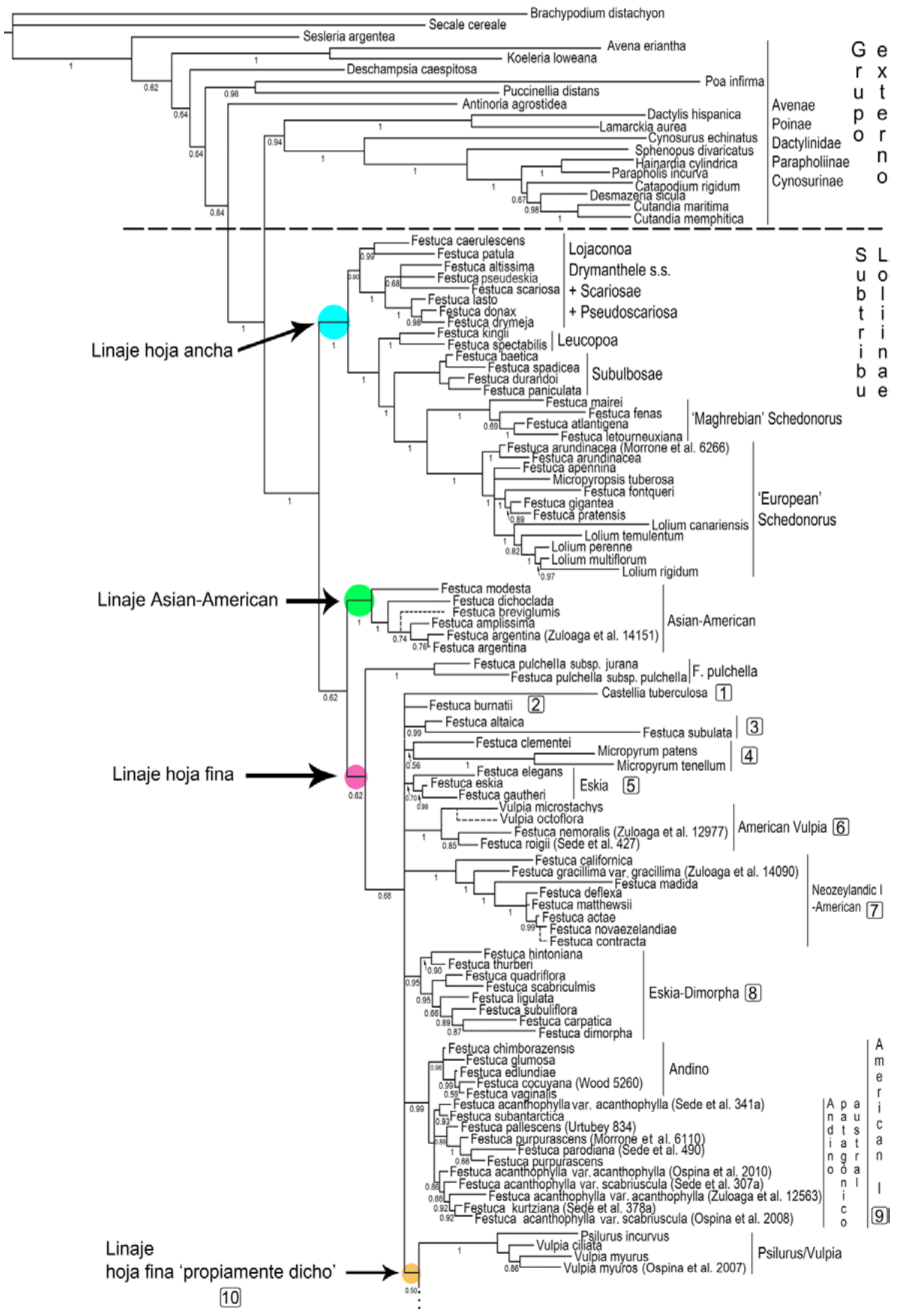

Figura 2. Árbol de inferencia bayesiana (consenso de mayoría, 50\%) de la subtribu Loliinae obtenido a partir de la matriz combinada (trnT-L + trnL-F + gaps + ITS), con valores de probabilidad posterior. Las ramas del árbol dibujadas con líneas punteadas corresponden a especies para las cuales no se obtuvieron secuencias nucleotídicas. Los números en recuadros corresponden al orden en que se describen los grupos de la politomía en el texto. 
Continuación

Linaje hoja fina 'propiamente dicho'

10

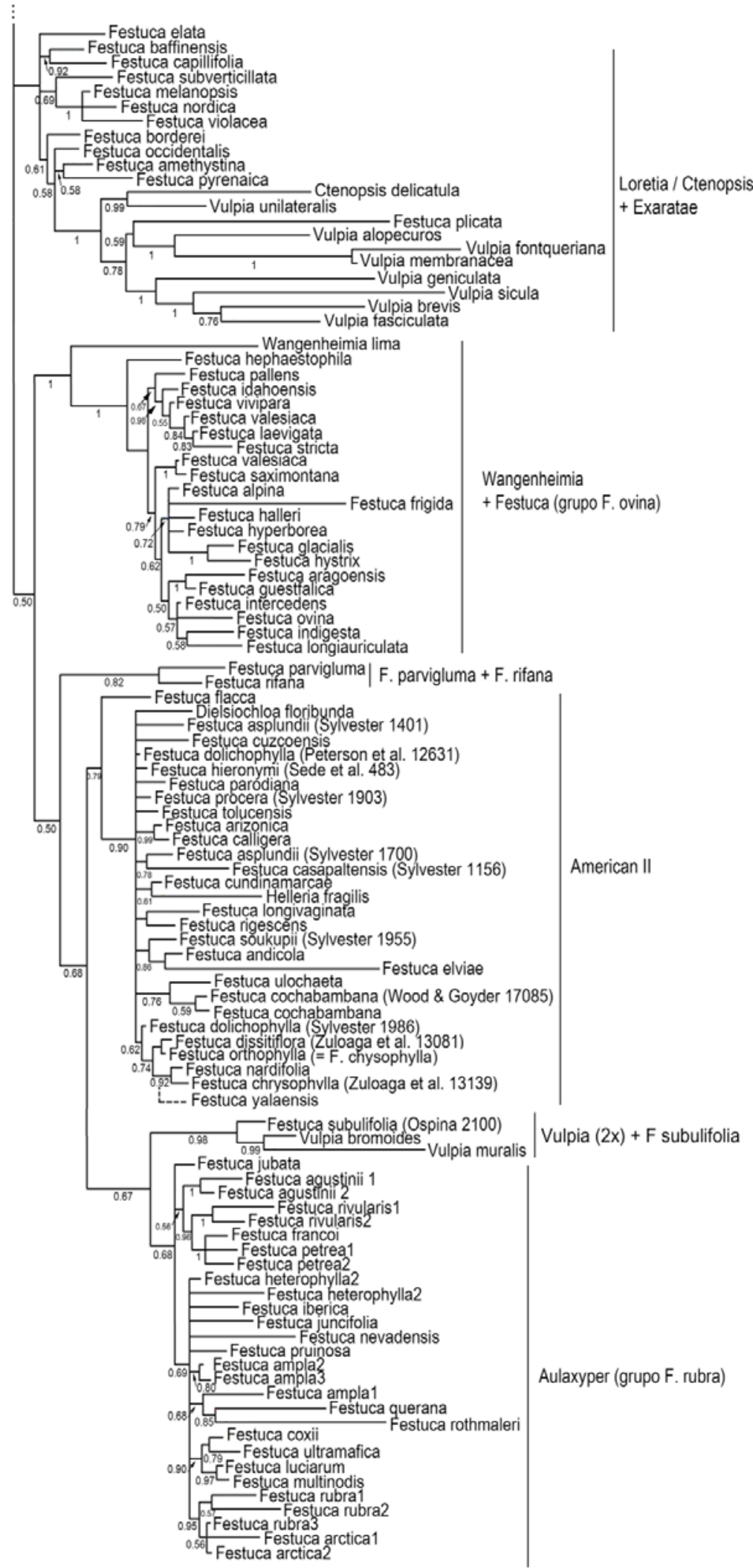

Figura 2. Continuación del Árbol de inferencia bayesiana. 


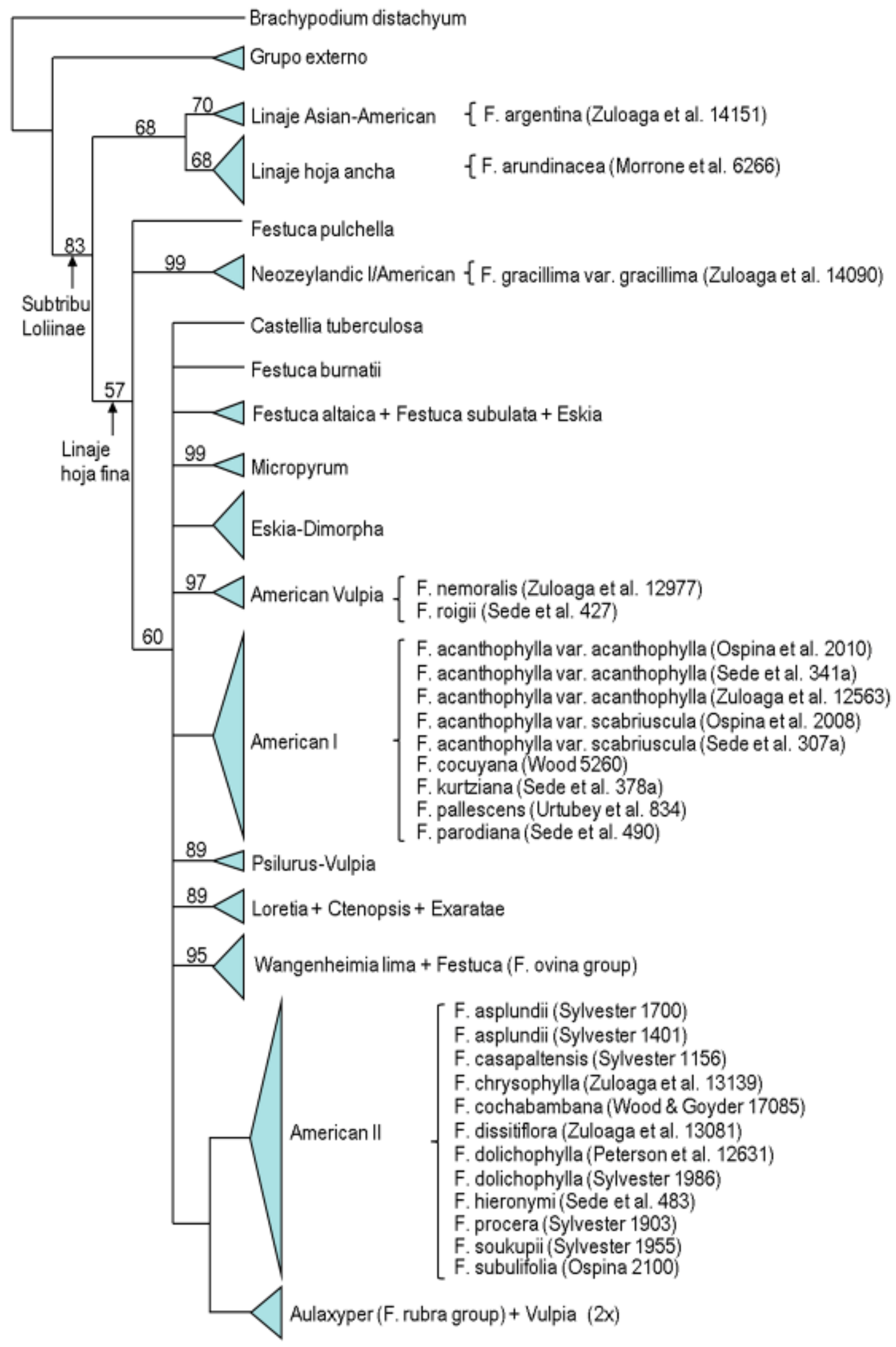

Figura 3. Resumen del árbol de consenso estricto de 8000 árboles más parsimoniosos de la subtribu Loliinae obtenido a partir de la matriz combinada (trnT-L + trnL-F + gaps + ITS) con el método de Máxima Parsimonia (MP), se muestran los valores de Bootstrap. A la derecha se listan las especies incorporadas en este análisis según su ubicación en el cladograma. 


\section{CAPÍtulo VI}

\section{CONTRASTE DE HIPÓTESIS Y CONCLUSIONES}

\section{CONTRASTE DE HIPÓTESIS}

Las hipótesis planteadas en el capítulo I de introducción se resuelven de la siguiente manera:

1. Las especies de Festuca que crecen en el Cono Sur son menos que las descriptas en las floras de países o catálogos.

Hipótesis aceptada. El número de especies de Festuca aceptadas para el Cono Sur es de 41, reduciéndose en consecuencia la cifra de 56 según el catálogo de plantas vasculares del Cono Sur Zuloaga et al. (2008). Aquí se estudiaron los taxones considerando un área geográfica mayor (el Cono Sur de Sudamérica) si se compara con la mayoría de los estudios taxonómicos previos que consideraban países. Como resultado, se encontraron variaciones continuas en la morfología de ciertas especies de amplia distribución que se resolvieron en sinonimias, reduciendo el número de especies aceptadas.

\section{Los caracteres anatómicos y micromorfológicos foliares muestran patrones diagnósticos que permiten reconocer las especies de Festuca del Cono Sur.}

Hipótesis parcialmente aceptada. Algunos caracteres anatómicos y micromorfológicos foliares de las especies de Festuca del Cono Sur resultan significativos si se consideran de forma conjunta, tal como la forma del transcorte foliar, tipo de plegamiento y distribución del tejido esclerenquimático. Otros caracteres como el número de haces vasculares y ciertas estructuras epidérmicas pueden presentar variación intraespecífica, por lo cual su significancia es menor.

\section{Los patrones anatómicos y micromorfológicos foliares de las especies de Festuca del Cono Sur se asocian con diferentes niveles altitudinales de distribución geográfica.}

Hipótesis aceptada. En las especies de Festuca que crecen a baja altitud, desde el nivel del mar hasta los $3000 \mathrm{~m}$, se observaron los cuatro tipos foliares; sin embargo, sólo las especies de Festuca del Cono Sur que presentaron los tipos B1, B2 y B3 logran desarrollarse en los niveles más altos de la distribución altitudinal, superando los $3000 \mathrm{~m}$. 


\section{Los términos "hoja fina" y "hoja ancha" utilizados frecuentemente en estudios taxonómicos y filogenéticos de Festuca, son lo suficientemente descriptivos para las especies del Cono Sur}

Hipótesis rechazada. Todas las especies tratadas en la literatura como "hoja ancha" se correspondieron con el tipo foliar A; en este caso se asocia el aspecto externo de la hoja con una estructura anatómica particular. En el grupo de especies generalmente denominado "hoja fina" se hallaron tres patrones anatómicos y micromorfológicos diferentes, por lo cual no hay una correspondencia estricta.

\section{Las especies sudamericanas de Festuca pertenecen a más de un linaje que colonizó este continente.}

Hipótesis aceptada. Las especies sudamericanas de Festuca integran los clados: AsianAmerican, American Vulpia, Neozeylandic I-American, American I, American II y Vulpia (2x).

\section{CONCLUSIONES}

\section{Conclusiones taxonómicas sobre las especies de Festuca en el Cono Sur}

- En el Catálogo de Plantas Vasculares del Cono Sur (Zuloaga et al. 2008) se citan 56 especies y seis variedades para el género Festuca. En este trabajo, y sobre la base de caracteres morfológicos vegetativos y reproductivos, se reconocieron 41 especies y 2 variedades de Festuca que crecen en el Cono Sur.

- El número de especies de Festuca que crecen en cada país del Cono Sur es la siguiente: Argentina, 40; Chile, 20; Uruguay, 2; Paraguay, 2; sur de Brasil, 2.

- Cuatro especies son endémicas de Argentina: Festuca nardifolia, Festuca pampeana, Festuca ventanicola y Festuca yalaensis. Solo una especie, Festuca panda, es endémica de Chile. No hay endemismos en Paraguay y sur de Brasil.

- Se propone la variedad Festuca acanthophylla var. scabriuscula, basada en la especie Festuca scabriuscula.

- Se excluyeron 5 especies de la flora del Cono Sur (Festuca dolichophylla, Festuca buchtienii, Festuca juncifolia, Festuca magensiana y Festuca tectoria); y se establecieron 18 nuevos sinónimos. 
- Se cita por primera vez a Festuca werdermannii para la Argentina. Se confirma la presencia de Festuca rigescens en Argentina y se amplía su distribución en Chile. Se recircunscribe el concepto morfológico de Festuca nardifolia, se excluye de Chile y se restringe su distribución a la Argentina, constituyendo un endemismo para este país.

- Se designaron 23 lectotipos de primer paso y 16 de segundo paso, se corrigieron a lectotipo términos que denotan tipos para 36 lectotipificaciones inferenciales.

- Los caracteres morfológicos de mayor utilidad para delimitar las especies de Festuca del Cono Sur fueron: hábito (cespitosas, rizomatozas), presencia o ausencia de aurículas, ramificación de la inflorescencia (panículas o panículas reducidas a racimos por reducción de las ramas secundarias), número de antecios por espiguilla, longitud de las glumas con respecto al antecio adyacente, presencia y longitud de la arista de las lemas, e indumento de las quillas de las páleas (glabro, piloso, escabroso), ápice del ovario (glabro o piloso).

- Actualmente, la mayor parte de las especies de Sudamérica, y especialmente las del Cono Sur, permanecen sin clasificar a nivel infragenérico. Esta clasificación deberá realizarse con posterioridad ya que los estudios filogenéticos que se están llevando a cabo en la subtribu muestran que la mayoría de los subgéneros y secciones actualmente aceptados no serían grupos monofiléticos y necesitarían ser revisados. También se observó, en la serie de trabajos filogenéticos descriptos en el capítulo de filogenia, como en los datos aportados en esta tesis, que la incorporación de más taxones modifica sustancialmente la topología de los árboles sobre los cuales se podría plantear una clasificación natural.

- Los complejos de especies de difícil delimitación pueden ser analizados por medio de técnicas multivariadas. No se detectaron caracteres morfológicos o anatómicos que permitan separar los ejemplares estudiados que corresponden a la morfología del complejo Festuca chrysophylla. Festuca orthophylla es un nuevo sinónimo de Festuca chrysophylla, establecido en este trabajo.

\section{Conclusiones sobre anatomía y micromorfología de las especies de Festuca del Cono Sur}

- Los caracteres anatómicos y micromorfológicos foliares de las especies del género Festuca del Cono Sur tienen relevancia a la hora de delimitar ciertas especies. Se observó que los de mayor significancia son la forma del transcorte, tipo de plegamiento 
y distribución del tejido esclerenquimático. Contrariamente, el número de haces vasculares y algunas estructuras epidérmicas como asperezas y macropelos varían a nivel intraespecífico. De esta forma, se evidencia que la caracterización sobre ciertos atributos anatómicos y micromorfológicos tomados en conjunto, pueden utilizarse para el reconocimiento de ciertas especies de Festuca del Cono Sur.

- El tipo anatómico y micromorfológico denominado A es homogéneo y todas las especies que lo integran has sido consideradas como de "hoja ancha". Los tipos llamados B1, B2 y B3 están presentes en especies que tienen láminas en forma de " $U$ " o de "V" y la mayoría de ellas se corresponden con el patrón "hoja fina". Sin embargo, dentro del grupo B2 algunas especies, por ejemplo Festuca argentina, fueron consideradas como de hoja ancha. Se evidenció que caracterizar a las especies desde la anatomía y micromorfología foliar aportaría información más precisa.

- Existe relación entre los rangos de distribución altitudinal que presentan las especies y el tipo anatómico y micromorfológico foliar. En especies que crecen a nivel del mar están representados todos los tipos foliares; sin embargo, sólo las especies que presentan los tipos foliares aquí denominados B1, B2 y B3 logran desarrollarse en altitudes cercanas a los $5000 \mathrm{~m}$ s.m.

Conclusiones sobre las relaciones filogenéticas de las especies sudamericanas de Festuca

- La subtribu Loliinae es monofilética y presenta dos grandes linajes: uno de especies de hoja ancha y otro de hojas finas. El incremento del muestreo taxonómico en la filogenia de Loliinae afecta principalmente a los linajes basales del grupo de hoja fina o a la ubicación de linajes intermedios. En este trabajo se incorporaron 67 secuencias nuevas y se obtiene una ubicación ambigua para el clado intermedio Asian-American y se pierde resolución en la base del clado de hojas finas, con respecto a trabajos previos (Inda et al. 2008 y anteriores).

- Las especies sudamericanas de Festuca pertenecen, en su mayoría, al linaje hojas finas, excepto Festuca argentina que se ubica en el linaje Asian-American. No hay representantes de especies nativas sudamericanas en el linaje hojas anchas.

- A su vez, dentro del linaje hojas finas, las especies sudamericanas de Festuca evolucionaron en diferentes sublinajes que colonizaron este continente: American Vulpia, Neozeylandic I-American, American I, American II y Vulpia (2x). 
- Los grupos en que se emplazan las especies sudamericanas de Festuca no muestran afinidad morfológica y o anatómica evidente entre sus especies. Sin embargo, se observa señal biogeográfica en estos clados.

- La mayor parte de las especies sudamericanas pertenecen a los linajes American I y American II. Estos linajes contienen exclusivamente especies polipliodes nativas de América.

- El clado American I presenta especies andinas del norte de Sudamérica que son tetraploides y especies andino patagónicas de distribución más austral, que son hexaploides. Las especies andinas del linaje American II son hexaploides. Es decir, que las especies que crecen en el norte de la cordillera de los Andes pertenecen a dos linajes diferentes que, además, se diferencian por su ploidía.

- Distintos linajes con especies sudamericanas coinciden con el patrón de distribución histórica que plantea que especies diploides europeas (de la zona del Mediterráneo) colonizaron América del Norte desde Asia y luego ocurrieron migraciones Norte-Sur, con aumento de la ploidía en las especies sudamericanas. Esto se observó en los linajes: Asian-American, American Vulpia, Neozeylandic I-American, American I y, posiblemente, American II.

- Más especies americanas de Festuca compartirían ancestros comunes con especies del género Vulpia. Tres de las especies de Festuca analizadas por primera vez en este trabajo se ubican en linajes que incluían solo especies de Vulpia: American Vulpia y Vulpia $(2 \mathrm{x})$.

- Algunas relaciones filogenéticas estarían oscurecidas por eventos de hibridación, poliploidía y heterogeneidad en las tasas de sustitución nucleotídica. Esto se evidencia en incongruencias entre las topologías obtenidas con diferentes marcadores. Otro factor que afectaría la reconstrucción de las relaciones filogenéticas en el grupo es el tamaño y representatividad geográfica del muestreo taxonómico, como ya se mencionó antes.

- Algunos de los subgéneros y secciones de Festuca no serían grupos naturales porque sus especies pertenecen a linajes diferentes. Especialmente, necesitan ser revisados los subgéneros de hoja ancha (Drymanthele y Subulatae) ya que algunas de sus especies se emplazan en los linajes de hoja fina. Cuatro especies del Subgénero Subulatae se ubican en el clado American II y una especie de Subulatae y otra de Drymanthele se ubican en el American I. Además las especies del subgénero Drymanthele se ubican tanto en el linaje de hoja ancha como en el linaje Asian American. La mayor parte de las especies 
sudamericanas de Festuca no han sido clasificadas infragenéricamente, pero su inclusión en la filogenia de Lolinnae modifica el esquema taxonómico actual.

- Algunos caracteres anatómicos presentes en especies de hoja ancha podrían haber evolucionado secundariamente en un linaje de hoja fina. Así se explicaría la presencia de Festuca purpurascens y Festuca parodiana en el grupo American I y Festuca flacca, Festuca cuzcoensis, Festuca cochabambana, Festuca ulochaeta y Festuca elviae en el grupo American II. 


\section{APÉNDICE I. MATERIAL DE HERBARIO ESTUDIADO}

Los ejemplares indicados con * son material de referencia del Capítulo IV de Anatomía.

\section{Festuca acanthophylla É. Desv.}

\section{a. var. acanthophylla}

ARGENTINA. Mendoza: Departamento Luján de Cuyo, Tres Esquinas, 2200 m, 1 enero 1921, sin colector, Flora mendocina 117 (SI); Malargüe, Valle Hermoso, borde de Laguna Grande, 28 enero 1963, Boelcke, O. et al. 10278 (SI). Ruta 222 en dirección a Valle Hermoso, 2477 m, 9 enero 2012, Sede, S. M. \& S. Denham 400 (SI). Las Leñas, 2100-2200 m, 1 febrero 1988, Lagiglia, H. 7567 (SI); Andes, S with backs below pass on Hwy 222 at N entrance to Valle Hermoso, 11 air WNW of Las Leñas, 2490 m, 3507'47"S, 70¹1'19"W, 6 marzo 2006, Peterson, P. M. et al. 19215 (SI). Neuquén: Departamento Collón Curá, Piedra del Águila, 205 m, 36² $42^{\prime} \mathrm{S}, 70^{\circ} 30^{\prime} \mathrm{W}, 30$ enero 1964, Boelcke, O. et al. 11393, 11395, 13678 (SI); Huiliches, arroyo Atreucó, 2010-2051 m, 36²45'S, 70³3' W, 3 febrero 1964, Boelcke, O. et al. 11476 (SI); Ruta 60, km 34, entrada del Parque Nacional Lanín, 960 m, 18 enero 2015, Denham, S. 429 (SI); Minas, Lagunas de Epulafquen, 1300 m, 36 50'S, 71' $\mathrm{W}, 16$ enero 1964, Boelcke, O. et al. 10893, 10937 (SI); Lagunas de Epulafquen, $1430 \mathrm{~m}, 36^{\circ} 50^{\prime} \mathrm{S}, 71^{\circ} 5^{\prime} \mathrm{W}$, 17 enero 1964, Boelcke, O. et al. 10943, 10983 (SI); Confluencia Ríos Pichi Neuquén y Neuquén, cajón Las Yeguas, 363' S, 7048'W, 23 enero 1970, Boelcke, O. et al. 13738, 13813 (SI); Cajón de

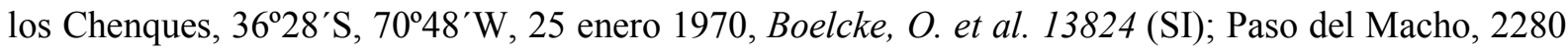
m, 36 26'S, 7046’W, 26 enero 1970, Boelcke, O. et al. 13959 (SI); Lagunas de Varvaco, 36 $17^{\circ} \mathrm{S}$, $70^{\circ} 37^{\prime} \mathrm{W}, 31$ enero 1970, Boelcke, O. et al. 14129 (SI); Arroyo Enfermera, 36²3'S, 70³7' W, 28 enero 1970, Boelcke, O. et al. 14014 (SI); Laguna Varvarco Tapia, cerro costa O de la laguna, $1986 \mathrm{~m}$, 14 febrero 2009, Biganzoli, F. 2190 (SI); Lagunas de Epulafquen, 1438 m, 36²49'2,9"S, 71²4'45"W, 16 enero 2003, Cocucci, A. et al. 2338* (SI ex CORD); Laguna Epulafquen, 3 febrero 1999, Seijo, G. 1701 (SI); La Primavera, 1750 m, 22 noviembre 1992, González, E. 903 (SI); Ruta Provincial 45, camino a Lagunas de Varvaco, 1280 m, 36 49'S, 40"S, 7042'12"W, 21 enero 2005, Prina, A. et al. 2809 (SI); Ruta 54, camino a las Lagunas de Varvarco, naciente del río Neuquén, 1834 m, 6 enero 2012, Sede, S. M. \& S. Denham 341 (SI); Ruta provincial 43, de Varvarco a Aguas Calientes, $50 \mathrm{~m}$ antes de la entrada a Bolillos, 1607 m, 5 enero 2012, Sede, S. M. \& S. Denham 331 (SI); Lagunas de Epulauquen, primer arroyo a la derecha del camino hacia Las Chaquiras, 1678 m, 7 enero 2012, Sede, S. M. \& S. Denham 361 (SI); Ñorquín, sin localidad, 25 febrero 2004, Prina, A. et al. 16030 (SI); 1 km. antes de Copahue, 14 enero 2004, Troiani, H. \& P. Steibel 15829 (SI) ; Copahue, 2000 m, enero 1986, Dubcovsky, J. \& A. Martinez 234* (BAB). 
CHILE. IV Región: Provincia Coquimbo, Carretera Panamericana, entre Pichidangui y Los Vilos, 40

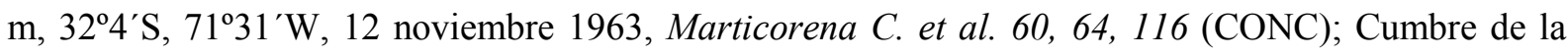
cuesta Los Hornos a $45 \mathrm{~km}$ al norte de Illapel, $1800 \mathrm{~m}, 20$ octubre 1941, Muñoz, C. \& G. Johnson 2332 (SGO). V Región: Provincia Quillota, cerro La Campana, Trayecto Placa Darwin a Mina, 3 diciembre 1981, Villagrán, C. \& I. Meza 3164 (SGO). Región Metropolitana: Provincia Cordillera, Río Yeso, 17 km de Romeral, 28 julio 1944, Biese, W. 763 (LIL); Cerro Anquehue, 1600 m, enero 1986, Dubcovsky, J. \& A. Martínez. 247, 249, 250*, 251 (BAB); Sin localidad, 100-1500 m, 18 diciembre 1934, Espinoza, L.M. s.n. Herb. Parodi (BAA); Provincia Los Andes, Los Maitenes, 1800 m, 8 diciembre 1962, Zöllner, O. 156, 162 (BAA, CONC); Provincia Valparaíso, Angostura, septiembre 1980, Etienne, M. s.n. CONC 54544 (CONC); In the dunes of Cochoa near Viña del Mar, 29 octubre 1982, Zöllner, O. 11354 (SI); Punta Imán, 2000 m, 11 enero 1932, Garaventa 2262 (BAA); Petroca, carretera Panamericana $5 \mathrm{~km}$ al norte de Longotoma, $70 \mathrm{~m}, 32^{\circ} 22^{\prime} \mathrm{S}, 71^{\circ} 25^{\prime} \mathrm{W}, 8$ enero 1967 , Ricardi, M. et al. 1828 (CONC). VI Región: Provincia Colchagua, on borders river Tinguiririca, no date, Zöllner, O. 11408 (SI). VII Región: Provincia Talca, Laguna del Maule, 2190 m, 360'S, 70³0'W, 20 enero 1961, Schlegel 3495 (CONC); On the borders of Laguna Maule, 2400 m, 22 enero 1983, Zöllner, O. 11599 (SI). VIII Región: Provincia Biobío, laguna del Laja, 1350 m, 21 enero 1969, Burkart, A. 27441 (SI); A orillas de la Laguna de Teno, 2500 m, 10 marzo 1967, Marticorena, C. \& O. Matthei 885 (CONC); Camino a las fumarolas de las termas de chillan, $2000 \mathrm{~m}, 36^{\circ} 55^{\prime} \mathrm{S}, 71^{\circ} 27^{\prime} \mathrm{W}, 1$ diciembre 2012, Ospina, J. C. et al. 2007, 2008, 2012, 2013 (SI, CONC); Antuco, 2000 m, 15 enero 1986, Pedersen, T. M. 14232 (SI). Provincia Ñuble, Termas de Chillán, 1720 m, 36º54'S, 71³1 'W, 4 diciembre 1995, Godoy 327 (CONC); Cordillera de Chillán, Shangri-Lá, 1500 m, 3652 'S, 71³0’W, 5 agosto 1992, Rodríguez, R. \& A. Marticorena 2957 (CONC); Río Maule, 2000 m, 23 enero 1991, Ruthsatz, B. 7098 (SI). IX Región: Provincia Malleco, Parque Nacional Nahuelbuta, 1460, 16 febrero 1957, Ricardi, M. 5394 (CONC).

b. var. scabriuscula (Phil.) Ospina, Aliscioni \& S. Denham comb. nov.

ARGENTINA. Neuquén: Departamento Catán Lil, near Catan Lil, 1200 m, 13 diciembre 1955, Böcher, T. W. et al 1638 (SI); Lácar, San Martín de los Andes, 11 diciembre 1952, Cabrera, A. L. 11184,11218 * (SI, LP); Parque Nacional Lanín, 24 febrero1968, Eskuche, U. \& Klein 258 (SI). Ruta nacional 234, km 59, alrededores del cerro Chapelco Chico, $847 \mathrm{~m}, 40^{\circ} 7^{\prime} 40^{\prime \prime} \mathrm{S}, 71^{\circ} 13^{\prime} 29^{\prime \prime} \mathrm{W}, 15$ julio 2008, Morrone, O. et al. 6153, 6156 (SI); Los Lagos, villa La Angostura, 18 febrero 1985, Rúgolo, Z. 1081 (SI); Minas, extremo norte de las Lagunas deVarvaco, campos arroyo Benítez, 36²17'S, 70³9'W, 1 febrero 1970, Boelcke, O. et al. 14329 (SI); Lagunas Epulafquen, 1300 m, 3650'S, 71²'W, 18 enero 1964, Boelcke, O. et al. 11019 (SI); Pozo de geometría número1, 1, 2200 m, 360'56"S, 70³3'14"W, 22 enero 2005, Prina, A. et al. 2847 (SI); Norquín, desembocadura lago

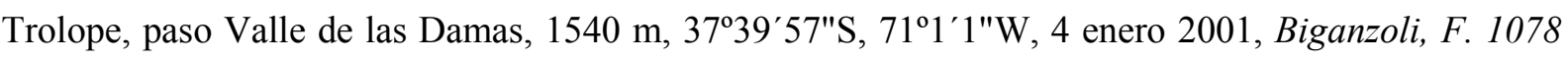
(SI). Copahue, 25 febrero 2004, Troiani, H. \& P. Steibel 16027, 16042 (SI); Picunches, Pino Hachado, $100 \mathrm{~m}$ antes del hito, $5 \mathrm{~km}$ pasando el puesto fronterizo, $1600 \mathrm{~m}, 16$ enero 2015, Denham, S. 409 (SI); 
Ruta 23, 1 km al S de Pino Hachado, márgen del arroyo Haichol, 1500 m, 16 enero 2015, Denham, $S$. 417 (SI); Intersección de la RN 22 con la RP 23, en frente a puesto de Gendarmería, 1510 m, 4 enero 2012, Sede, S. M. \& S. Denham 306, 307 (SI); Zapala, no locality, enero 1986, Dubcovsky, J. \& A. Martínez 222 (BAB). Río Negro: Departamento Bariloche, Pampa Linda, 16 enero 1952, Boelcke, O. et al. 5679 (SI); Bariloche, Parque Nacional Nahuel Huapi, $47 \mathrm{~km}$ W of Hwy 258 road towards Cerro Tronador, $852 \mathrm{~m}, 41^{\circ} 14^{\prime} 20,6^{\prime \prime} \mathrm{S}, 7^{\circ} 45^{\prime} 32,6^{\prime \prime} \mathrm{W}, 29$ enero 2003, Peterson, P. M. et al. 17354 *(SI).

CHILE. IX Región: Provincia Cautín, Volcán Llaima, 1000 m, 9 diciembre 1944, Gunckel, H. 15105, 15109, 15110 (CONC, BAA, LP); Cunco, 370 m, 20 febrero 1920, Hollermayer, A. 140 (BAA); Volcán Llaima, 29 enero 1942, Montero, O. 4247 (BAA, SI ex CONC), Provincia Malleco, loma de Lancú, cerca del estero El Alambrado, 920 m, 38 $14^{\prime} \mathrm{S}, 71^{\circ} 27^{\prime} \mathrm{W}, 9$ enero 1977, Marticorena et al. $1353 *(\mathrm{CONC})$.

\section{Festuca argentina (Speg.) Parodi}

ARGENTINA. Chubut: Departamento Biedma, Puerto Madryn, 50 m, 29 noviembre 1979, Beescow et al. 984 (BAB); Escalante, Pampa del Castillo, 6 diciembre 1971, Boelcke, O. et al. 15435 * (BAB, SI); Futaleufú, Río Corcovado, no date, N. Illin N. 204 (SI); Laguiñeo, camino Tecka a Corcovado a 65 km de Tecka, 25 febrero 1986, Dubcovsky, J. 693 (BAB); Sierra de San Bernardo, 650 m, 9 enero 1986, Dubcovsky, J. \& A. Martínez 113 (BAB); Estancia los Matinales, 300 m, 24 diciembre 1938, Goodspeed et al. 23813 (SI); Paso de Indios, ruta 24 a $50 \mathrm{~km} \mathrm{S,} \mathrm{Paso} \mathrm{de} \mathrm{Indios,} \mathrm{desvío} \mathrm{a} 23$ km, SO,

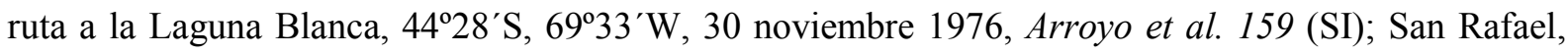
Sierra del Nevado, pampa entre arroyo Agua del Gaucho y el zanjón del lado al S-SE de los Cerros Morado, 1600 m, 35 40’ S, 68²2'W, 8 diciembre 1973, Boelcke, O. et al. 15735 (SI); Sarmiento, ruta

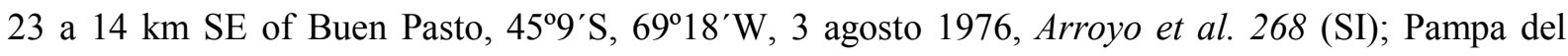
Castillo, 1 diciembre 1932, Castellanos, A. 7619 (SI); desconocido, no localidad, 1915, Carette, E. 15 (SI); desconocido, no localidad, 6 febrero 1914, Arroyo, T. 509 (SI). Mendoza: Departamento Luján de Cuyo, Potrerillos, 2180 m, 30 diciembre 1996, Méndez, E. 5059 (SI); Pampa del Castillo, 4 abril 1987, Soriano, A. s.n. SI-28004, SI-28005 (SI); Pampa del Castillo, saliendo 11 km hacia Sarmiento, 6 diciembre 1981, Villamil, C. B. \& E. Cáceres 2284 (SI). Neuquén: Departamento Aluminé, 63 km de Zapala por ruta 13 hacia Aluminé, 1700 m, 19 febrero 1989, Dubcovsky, J. 637 * (BAB); desconocido, sin localidad, 22 febrero 1989, Dubcovsky, J. 676 (SI); desconocido, ruta 237, cerca estancia La Lonja, 28 noviembre 1963, Vallerini, J. 376 (SI). Río Negro: Departamento Nueve de Julio, Cerro Corona, 27 noviembre 2001, Troiani, H. \& P. Steibel 15076, 15083 (SI); Pilcaniyeu, $20 \mathrm{~km}$ al S de Paso Flores, 10 diciembre 1981, Cabrera, A. L. et al. 33017 (SI); Ruta Nacional 40 km 2145, camino de Paso Flores a Bariloche, 726 m, 40³4'29"S, 7051'15"W, 7 diciembre 2008, Morrone, O. et al. 6167 (SI); Veinticinco de Mayo, establecimiento Don José, $37 \mathrm{~km}$ al sudoeste de Maquinchao en dirección

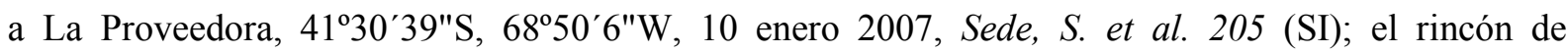
Cañadón Cortaderas-Primer escalón de la Meseta de Somuncurá, 27 noviembre 2001, Troiani, H. \& P. 
Steibel 15030 (SI); Valcheta, Cerro Puntudo, 27 noviembre 2002, Troiani, H. \& P. Steibel 15488 * (SI). Santa Cruz: Departamento Deseado, lomadas bajando al mar al Sur de Caleta Olivia, $206 \mathrm{~m}$, 464ㄴ $48^{\prime \prime S}, 67^{\circ} 23^{\prime} 1^{\prime \prime W}, 6$ noviembre 2005, Cocucci, A. et al. 3758 (SI). Puerto Deseado, 3 enero 1914, Inter Patagonicum 160 (SI); Güer Aike, sin localidad, 12 febrero 1985, Hunziker, J. H. 6855 (BAB). $27 \mathrm{~km} \mathrm{~W}$ of Calafate on road towards Perito Moreno Glacier, $210 \mathrm{~m}, 50^{\circ} 19^{\prime} 23,6^{\prime \prime} \mathrm{S}$, 72³7'37,9"W, 20 enero 2003, Peterson, P. M. et al. 17158 (SI); Lago Buenos Aires, ruta 41 de Los Antiguos a Paso Roballos, 15 km s, 564 m, 4639'40"S, 71³6’31"W, 30 noviembre 2009, Biganzoli, F. et al. 2274 * (SI). Lago San Martín, Estancia La Federica, 390 m, 48 $58^{\prime} \mathrm{S}, 72^{\circ} 11^{\prime} \mathrm{W}, 23$ enero 1967, Boelcke, O. et al. 12700 (SI). Jaramillo, 300 m, 25 noviembre 1929, Donat s.n. (SI); Lago Argentino, Ruta Provincial número 11, Cerro Comisión, 8 diciembre 2008, Guerrido, C. 806 (SI); El Calafate, médanos en la costa del Lago Argentino, 2 noviembre 2001, Guerrido, C. 382 (SI).

\section{Festuca argentinensis (St.-Yves) Türpe}

ARGEnTINA. Catamarca Departamento Tinogasta, Aguas Calientes, 4030 m, 31 enero 1983, Almonacid R. V. 27 (LIL); Andes, E of paso de San Francisco ca. 18 rd km on hwy 60 to Fiambala, 4010 m, $26^{\circ} 55^{\prime} 20^{\prime} \mathrm{S}, 68^{\circ} 8^{\prime} 41$ "W, 16 marzo 2006, Peterson P. M. et al. 19367 (SI). Jujuy: Departamento Susques, Alto Chorrillos, subida, 4100 m, 16 febrero 1980, Cabrera L. A. et al. 31749 (SI); Santa Victoria, W slope Sierra de Santa Victoria, Bain 6 rd km SW of Abra Lizoite, 38 air km ESE la Quiacaon Hwy 5, 4172 m, 22 ${ }^{\circ} 14^{\prime} 46$ "S, 65 ${ }^{\circ} 15^{\prime} 28$ "W, 28 marzo 2006, Peterson P. M. et al. 19578 (SI); Yavi, Quebrada de Salitre, 3500 m, 23 febrero 1940, Meyer 14968 (LIL). Salta: Departamento Los Andes, Paso de Acay, Río d.l. Pastos: vega 101, 4600 m, 2 marzo 1997, Erschb Ru. 9777, 9778 (SI); Tocomar, Seitental: vega 155, 4360 m, 3 marzo 1997, Erschb Ru. 9898 (SI); pie del Abra del Acay, Ruta 40, 4080 m, 20 febrero 1987, Nicora et al. E. G. 8931 (SI). San Juan: Departamento Iglesia, vertiente occidental de la Cordillera de Ansilta, Los lepes, 12 enero 1953, Castellanos A. s.n. LIL 443957 (LIL); Quebrada del Agua Negra, 3000 m, 9 diciembre 1979, Cabrera L. A. et al. 31104 (SI); Quebrada del Agua Negra, El Arenal, 3800 m, 12 diciembre 1979, Cabrera L. A. et al. 31187 (SI); cordillera de Colanguil, quebrada De la Vicuñita, 3400, 3400 m, 26 enero 1995, Kiesling R. 5460 (SI); Reserva de San Guillermo, vega antes de cruzar el Río Macho Muerto (Lado e), 15 febrero 18982, Ulibarri E. et al. 5880 (2 pliegos), 5460 (SI); Quebrada Agua Negra, Arroyo Las pircas, vega 11, Randzone, 3900 m, 21 enero 1995, Ruthsatz 8702 (SI); Pachón, alta cordillera de San Juan, 3600 m, 26 febrero 1975, Luti-Barrera 1429 (2 pliegos) (SI); alta cordillera., 3200 m, febrero 1980, Maqueda G. L. s.n. SI 065936 (SI); Jáchal, margen el arroyo Lavadero, 14 diciembre 2000, sin colector 8984 (SI). Tucumán: Departamento Tafí, Cumbres Calchaquíes cerro Bayo, alrededores del

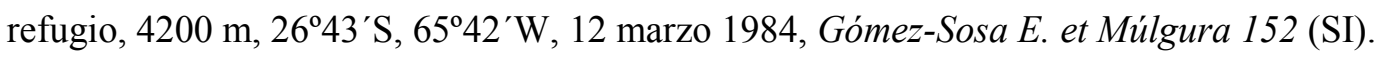

\section{Festuca arundinacea Schreb.}

ARGENTINA. Buenos Aires: Partido of Coronel Dorrego, Oriente, Río Quequén Salado, $700 \mathrm{~m}$ río bajo de la usina, 33 m, 38 44'19"S, 60³4'9"W, 4 noviembre 2008, Biganzoli, F. et al. 1998 (SI); 
Partido Coronel Rosales, Junto al camino, 50 m, 31 octubre 1985, Villamil, C. B. 3449 (SI). Partido of Guaminí, Ruta Provincial 205 y Ruta Provincial 85, 95 m, 22 diciembre 1998, Seijo, G. 1339 (SI); Partido Magdalena, Ruta 36 y desvío a Bavio, 3 diciembre 2009, Morrone, O. 6266* (SI); Partido of Punta Indio, Ruta 11, 6-7 km al N del cruce con ruta 36, 3 febrero 2009, Denham, S. \& M. E. Múlgura 275 * (SI). Entre Ríos: Departamento Uruguay, Concepción del Uruguay: Campichuelo a colonia Elía, 14 julio 1963, Burkar, t A. 24719 (SI). Neuquén: Departamento Picunches, Arroyo Primero Pinos, 24 febrero 2004, Troiani, H. \& P. Steibel 15957 (SI). Santa Cruz: Departamento Güer Aike, 8

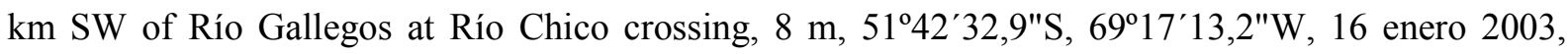
Peterson, P. M. et al. 17066 (SI); Río Gallegos, sobre ruta 5 a orilla del río, 17 diciembre 1985, Villamil, C. B. 3786 (SI).

CHILE. II Región: Provincia El Loa, Talabare, en chacra, 3500 m, 10 abril 1998, Villagrán, C. 9476 (CONC). VI Región: Provincia Cardenal Caro, cerca de Pichilemu en potreros, septiembre 1956, colector desconocido s.n. (SGO072165).VII Región: Provincia Talca, Pencahue a orillas del camino, octubre 1972, Ramirez, C. s. $n$. * (SGO685566).

\section{Festuca castilloniana Türpe}

Se conoce solamente de material tipo: ARGENTINA. Tucumán: Departamento Tafi, "Cumbres Calchaquíes, Portezuelo", 3600 m s.m., marzo 1913, L. Castillón 2884 (holotipo LIL 44250!; isotipo BAA 00002021!).

\section{Festuca chrysophylla Phil.}

ARGENTINA. Catamarca: Departamento Antofagasta de la Sierra, ruta 53, falda de Ciénaga, 19 febrero 1980, Cabrera, A. L. et al. 31849 * (SI); Belén, dejando la Ruta Provincial número 43, entre Villa Vil y Antofagasta de la Sierra, Laguna Blanca, Sectores de campo entre viviendas, $3290 \mathrm{~m}$, 26 $56^{\prime} \mathrm{S}, 3^{\circ} 7^{\prime} \mathrm{W}, 20$ abril 2006, Biurrun, F. et al. 8319 (SI); Camino a Antofagasta, Pasto Ventura, 26 febrero 1981, Cabrera, A. L. et al. 32548 (SI); Reserva Laguna Blanca, 4200 m, 16 marzo 1989, Reca, A. R. et al. 1, 40, 41 52, 143, 169, 196 (SI); Tinogasta, paso de San Francisco, La Coipa, 3600 m, 26 febrero 1995, Ruthsatz, B. 9253 * (SI). Jujuy: Departamento Cochinoca, Abra Pampa, estación

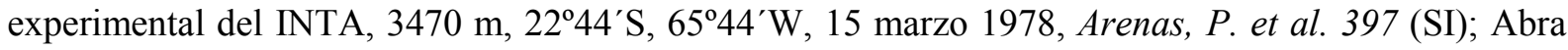
Pampa, Cerro Huancar, 3500 m, 17 febrero 1963, Cabrera, A. L. et al. 15273 (SI); Peñas, ojo de agua,

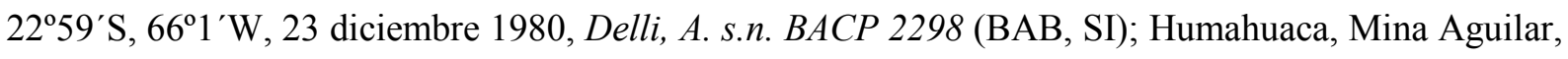
4600 m, 15 enero 1948, Cabrera, A. L. et al. 18975 (SI); Camino a Palca de Aparzo, a 28 km de Humahuaca, 4200 m, 26 febrero 1983, Hunzinker, J. et al. 10422 (SI); Sierra del Aguila, 4000 m, 29 marzo 1929, Venturi, S. 8734 (SI); Entre Palca de Aparzo y Santa Ana, 3870 m, 239'34"S, 655'30"W, 11 febrero 2007, Zuloaga, F. O. et al. 9180 (SI); Rinconada, Laguna de Pozuelos, 3690 m, 22²4'S, 6557'W, 11 febrero 1995, Deginani, N. et al. 611 (SI); Pan de Azúcar, 3 marzo 1966, de la Sota, E. 4220 (SI). $67 \mathrm{~km}$ al S de Mina Pirquitas, Laguna de Vilama, 4530 m, 22³7' S, 66º54'W, 14 
febrero 1998, Morrone, O. 2555 (SI); Sierra de Quichagua, Hwy 74, 3.7 rd km W Río Rachayte, 3940

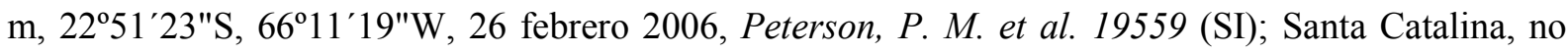
locality, $22^{\circ} 1^{\prime} \mathrm{S}, 65^{\circ} 57^{\prime} \mathrm{W}, 12$ febrero 1980, Arenas, P. et al. 1790 (SI); Región de la puna, no date, Fritz Claren 11615 (SI); Susques, Alto Chorrillos, 4600 m, 27 febrero 1972, Cabrera, A. L. et al. 22520 (LP). N of Susques 33 air km, NE Paso de Jama, 4132 m, 26 marzo 2006, Peterson, P. M. et al. 19547 (SI); Paso de Jama, limite con Chile, 4250 m, 2313'36"S, 67³'44"W, 23 febrero 2009, Zuloaga, F. O. et al. 11143 (SI); Tumbaya, subida al Abra de Lipán, 3800 m, 15 febrero 1980, Cabrera, A. L. et al. 31676 (SI); Abra de Lipán, 4000 m, 24 marzo 1979, Cabrera, A. L. et al. 30528 * (SI); Camino de Purmamarca al Abra de Lipan, Abra Blanca, 3900 m, 17 febrero 1985, Kiesling, R. 5307 (SI); Alto del Morado, entre Purmamarca y Tres Morros, 4175 m, 2342'17"S, 6540'12"W, 18 febrero 2008, Zuloaga, F. O. et al. 10200 (SI). La Rioja: Departamento Chilecito, Sierra de Famatina, 4000 m, 3 febrero 1995, Ruthsatz, B. 9138 (SI); Famatina, entre los Corrales y Cueva Pérez, 3500 m, 13 enero 1976, Cabrera, A. L. et al. 27178, 27204 (SI). Salta: Departamento Los Andes, ruta 51, 8 km

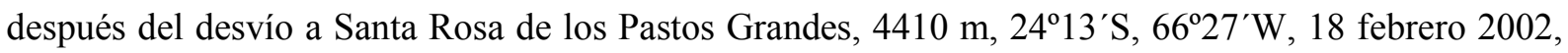
Cialdella A. M. et al. 419, 431 (SI), Desvío de la ruta 51 hacia viaducto La Polvorilla, $3950 \mathrm{~m}$,

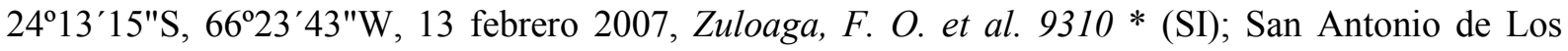
Cobres, alta quebrada de Polcosillas, 4200 m, 11 febrero 1945, Cabrera, A. L. et al. 8637 (LP); Alto Chorrillos, 4560 m, 27 enero 1949, Cabrera, A. L. et al. 122 (BAB). Hwy 51 W of San Antonio de los

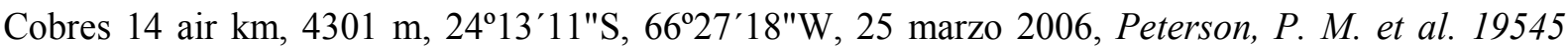
(SI); Santa Victoria, Ruta Provincial 145 de El Condor a Nazareno, Abra del Condor, $4500 \mathrm{~m}$,

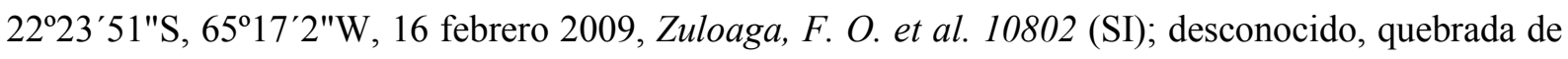
Pozite, 3500 m, 2 febrero 1943, Meyer, T. 4899 (SI); desconocido, Laguna Cerca seca, Cerro el Cajón, no date, Rodríguez 1351 (SI). Tucumán: Departamento Tafí del Valle, Cumbres Calchaquíes, Huaca Huasi, Laguna Nostra, 4300 m, 2640’S, 654' W, 14 Mach 1984, Gómez-Sosa, E. et al. 182 * (BAB); desconocido, El Pelado, 4000 m, 15 marzo 1912, Rodríguez $425 *$ (SI).

CHILE. I Región: Provincia Tarapacá 82 Km NE of Huara on HWY A-55 towards Colchane, 3890 m, 19³9'12,2"S, 698'48,6"W, 25 marzo 2001, Peterson, P. M. et al. 15630 (SI), 92 km Neof Huara on

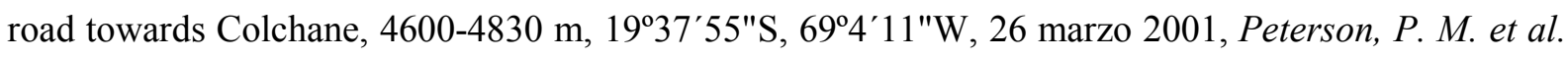
15633 (SI), $94 \mathrm{~km} \mathrm{NE}$ of Huaraon road towards Colchane, 4078 m, 19³7'44"S, 69²'24"W, 26 marzo 2001, Peterson, P. M. et al. 15637 (SI), $22 \mathrm{~km}$ E of Zapahuira at Portezuelo Cahpiquiña, $4460 \mathrm{~m}$, 18¹9'30"S, 69030'13"W, 2 abril 2001, Peterson, P. M. et al. 15731, 15732 (SI), $133 \mathrm{~km}$ E of Arica at Termas Jurasi above Putre, 4045-4150 m, 18 $12^{\prime} 24 " \mathrm{~S}, 69^{\circ} 30^{\prime} 53^{\prime \prime} \mathrm{W}, 3$ abril 2001, Peterson, P. M. et al. 15745 *, 15748 (CONC, SI), Termas Chirigualla, SW of Chungará, $4480 \mathrm{~m}, 18^{\circ} 20^{\prime 36}$ "S, 69¹0'30"W, 5 abril 2001, Peterson, P. M. et al. $15767 *$ (SI); $66 \mathrm{~km} \mathrm{NW}$ of Colchane on road towards Chiclayo at Porto Capitán, just E of Cerro Capitán, 4464 m, 18 $55^{\prime} 57^{\prime \prime} \mathrm{S}, 68^{\circ} 56^{\prime} 27^{\prime \prime} \mathrm{W}, 28$ marzo 2001, Peterson, P. M. et al. 15674 * (SI); Cordillera Cerro Columtsca, Apacheta, 4600 m, marzo 1926, Werdermann, E. 1072 * (SI). II Región: Provincia Antofagasta Km 31,5 East from San Pedro de Atacama on paved HWY Towards Argentine border at Paso de Jama, 3895 m, 22²5'7"S, 
533'40"W, 22 marzo 2001, Peterson, P. M. et al. $15508^{*}$ (SI), Km 33.5 East from San Pedro de Atacama on longer or equal HWY towards Argentine border at Paso de Jama, adjacent to pipeline pumping station, $4120 \mathrm{~m}, 2^{\circ} 55^{\prime} 31^{\prime \prime} \mathrm{S}, 67^{\circ} 52^{\prime} 20^{\prime \prime} \mathrm{W}, 16$ marzo 2001, Peterson, P. M. et al. $15510^{*}$ (SI); $155 \mathrm{~km}$ on road from San Pedro de Atacama to Paso Jama on Argentine border, $4400 \mathrm{~m}$, 2313'35"S, 67³'59"W, 17 marzo 2001, Peterson, P. M. et al. 19535 (SI); Cuesta de Cajita on road

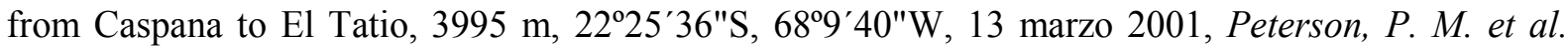
15568 * (CONC), $6 \mathrm{~km}$ of El Tio"Hotel" km 80 on road noth from San Pedro de Atacama to El Tatio, 4396 m, 22²4'56"S, 68²'15"W, 19 marzo 2001, Peterson, P. M. et al. 15570 * (SI), $25 \mathrm{kn}$ NW of Estación carcote on steep rocky slopes with Festuca, 4860 m, 21 ${ }^{\circ} 17^{\prime} 18^{\prime \prime} \mathrm{S}, 68^{\circ} 30^{\prime} 41^{\prime \prime} \mathrm{W}, 22$ marzo 2001, Peterson, P. M. et al. 15602 (SI), El Loa, cordón ceja alta lado SE, 4500-4600 m, 2321' S, 67¹9’W, 8 abril 1997, Arroyo et al. 97302 (CONC). XV Región: Provincia Arica, Las Cuevas, 4400 m, 5 mayo 1977, Escobar A. H. $118 x$ (SI). $26 \mathrm{~km}$ E of Zapahuira on topo of cerro Chapiquiña, 4810 m, 18²0'S, 7"S, 69³0'W3,6"W, 1 abril 2001, Peterson, P. M. et al. 15713, 15723 (SI); $110 \mathrm{~km} \mathrm{NE}$ of Huara on road towards Colchane, 4120 m, 19³3'S, 2"S, 68 56'57"W, 27 marzo 2001, Peterson, $P$. M. et al. 15660, $15662 *(\mathrm{SI}) .3 \mathrm{~km} \mathrm{~N}$ of Parinacota and road towards Visviri, 18 $10^{\circ} \mathrm{S}, 56 " \mathrm{~S}$, 69 $9^{\circ} 5^{\prime} 51$ "W, 4 abril 2001, Peterson, P. M. et al. 15755 (SI); Provincia Parinacota, camino de Putre a Chucuyo $4100 \mathrm{~m}, 18^{\circ} 41^{\prime} \mathrm{S}, 6^{\circ} 31^{\prime} \mathrm{W}, 12$ febrero 1964, Marticorena et al. 191 (CONC); Laguna Chungara, 4750 m, 31 marzo 1992, Ruthsatz B. 8537 (SI), Cerca de Pacollo, 4000 m, 18¹0'S, 69³ $30^{\prime} \mathrm{W}, 8$ marzo 1984, Arroyo et al. 84-655 (SI), Laguna de Parinacota, $4500 \mathrm{~m}, 18^{\circ} 13^{\prime} \mathrm{S}, 69^{\circ} 14^{\prime} \mathrm{W}$, 22 enero 1969, Zöllner, O. 3345 (SI), Cord. Volcan Tacora, Chislluma, 4500 m, abril 1926, Werdermann, E. $1161 *(\mathrm{SI})$.

\section{Festuca cirrosa (Speg.) Parodi}

ARGEnTINA. Tierra del Fuego e Islas del Atlántico Sur: Departamento Ushuaia, Isla de los Estados, Bahia Franklin Punta Tibaldo Hacia Punta Santiago, 54 $52^{\prime} \mathrm{S}, 64^{\circ} 41^{\prime} \mathrm{W}, 11$ diciembre 2009, Biganzoli, F. 702, $709^{*}$ (SI); Isla de los Estados, Puerto Vancouver, 54 47 ' $\mathrm{S}, 64^{\circ} 3^{\prime} \mathrm{W}, 26$ noviembre 1998, Biganzoli, F. 505 * (SI). Isla de los Estados, Puerto Vancouver, orillas del mar, 54\%47'S, $64^{\circ} 5^{\prime} \mathrm{W}, 28$ noviembre 1967, Nicora, E. et al. 7241 (SI).

CHILE. XII Región: Provincia Magallanes, sin localidad, sin fecha, Bonarelli 108 (SI). Caleta Lientur Isla Wollaston, 55 $44^{\prime} \mathrm{S}, 67^{\circ} 19^{\prime} \mathrm{W}, 22$ febrero 1980, Dollenz, O. 811 * (CONC), Plantae Magellanicae, no date, Herb. Darwinion 619, 623, 625, 672, 674 (SI). Isla Grevy, Cabo de Hornos, Punta Dillon, Paso Norte, 18 enero 1982, Pisano, E. et al. 5431 (SI). Isla Bayly, Costa Canal Washinton, 55³8'S, 6753 W, 21 febrero 1980, Pisano, E. et al. 5096 (SI). Isla, Hornos, Cabo de Hornos, Islote al S.E. Turbal ciperoideo, 16 noviembre 1981, Pisano, E. et al. 5246, 5259 (SI). Isla Grevy, Cabo de hornos, Rada Norte, Ba Gretton, 15 enero 1982, Pisano, E. et al. 5356 (SI). Isla Wollaston, Caleta Lientur, $55^{\circ} 44^{\prime} \mathrm{S}, 67^{\circ} 19^{\prime} \mathrm{W}, 15$ febrero 1980, Pisano, E. et al. $4976^{*}$ (SI). Caleta Lientur, Isla Wollaston, 55 $44^{\prime} \mathrm{S}, 6^{\circ} 19^{\prime} \mathrm{W}, 16$ febrero 1980, Pisano, E. 4995 (CONC, SI). Provincia Ultima Esperanza, Fiordo 
Encuentros, $1 \mathrm{~m}, 51^{\circ} 46^{\prime} 5,4^{\prime \prime} \mathrm{S}, 73^{\circ} 35^{\prime} 7,9^{\prime \prime} \mathrm{W}$, no date, Aravena, J. C. et al. $1433^{*}$ (CONC). Isla Piazzi, caleta Ocación, Abra Leackey's Retreat, 80 m, $1^{\circ} 44^{\prime} \mathrm{S}, 74^{\circ} 1^{\prime} \mathrm{W}, 18$ enero 1976, Dollenz, O. et al. s. n., T.B.P.A. 1063 (SI). Cabo Colorado, Paso Charteris, canal Grappler, 49³2'S, 4"S, 74¹1'6"W, 19 diciembre 1988, Pisano, E. 6463 (CONC). Bahia del Indio, lote San Isidro, Río Yumbel, 5347'S,

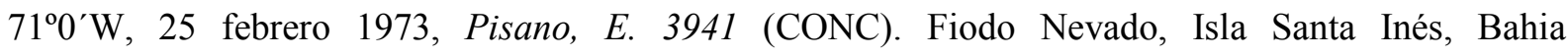
Havergal, 53³1'S, 7246’W, 20 febrero 1990, Pisano, E. et al. 6600* (CONC). Península Roca, Seno Resi, costa, 51 $51^{\prime}$ S, $73^{\circ} 2^{\prime} \mathrm{W}, 21$ enero 1978, Pisano, E. et al. s. n., T.B.P.A. 2766 (SI).

\section{Festuca contracta Kirk}

ARGENTINA. Santa Cruz: Departamento Güer Aike, estancia Rospentek, meseta La Torre, 700 m, 51³2'S, 72²'W, 25 enero 1978, Roig, F. et al. s.n. T.B.P.A.-FIT 2924, 2926, $3004^{*}$, 3050 (SI); Lago Argentino, no locality, 1958, Peter James 4034 (SI). Tierra del Fuego e Islas del Atlántico Sur: Departamento Ushuaia, Isla de los Estados, Bahia Franklin Punta Tibaldo Hacia Punta Santiago, $54^{\circ} 52^{\prime} \mathrm{S}, 64^{\circ} 41^{\prime} \mathrm{W}, 29$ noviembre 1999, Biganzoli, F. $663^{*}(\mathrm{SI})$.

CHILE. XII Región: Provincia Antártica Chilena, Puerto Williams, isla Navarino, Cerro Bandera,

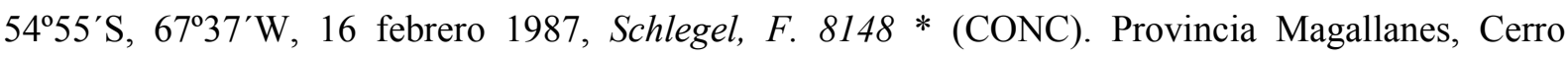
Mirador, 550-650 m, 53ำ $10^{\prime} \mathrm{S}, 71^{\circ} 1^{\prime} \mathrm{W}, 29$ diciembre 1971, Pisano, E. 3363 (CONC). Cerro Mirador, $53^{\circ} 10^{\prime} \mathrm{S}, 71^{\circ} 1^{\prime} \mathrm{W}, 7$ febrero 1974, Dollenz, A. 154 (CONC). Provincia Ultima Esperanza, Monte

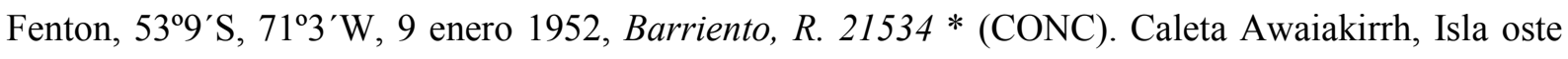
Montaña al S del itsmo, 300 m, 26 enero 1982, Pisano, E. et al. 5533 (CONC, SI); Cerros de canchas de sky, 539'S, 7055'W, 3 febrero 1962, Ricardi \& Matthei 318 (CONC); Península Roca, Seno Resi, $750 \mathrm{~m}, 51^{\circ} 51^{\prime} \mathrm{S}, 73^{\circ} 2^{\prime} \mathrm{W}, 27$ enero 1978, colector desconocido s.n. T.B.P.A 2907 (SI).

\section{Festuca dissitiflora Steud. ex Griseb.}

ARGENTINA. Jujuy: Departamento Tilcara, camino de Campo de Laguna hacia Alfarcito, $4055 \mathrm{~m}$, $23^{\circ} 35^{\prime} 8^{\prime \prime} \mathrm{S}, 65^{\circ} 18^{\prime} 30^{\prime \prime} \mathrm{W}, 13$ febrero 2010, Zuloaga et al. 11763 (SI); camino de Yuto Pampa a Coral de Ventura, 3520 m, 23 $34^{\prime} 19$ "S, 65 o $14^{\prime} 44$ "W, 12 febrero 2010, Zuloaga et al. 19629 (SI); between Hwy 9 and Río Grande at iturbe on Hwy 13 to Iruya, ca $0,5 \mathrm{~km} \mathrm{w}$ of Iturbe, $3417 \mathrm{~m}, 22^{\circ} 58^{\text {' }}$ 53 "S, $65^{\circ} 21$ ' 21 "W, 30 marzo 2006, Peterson P. M. et al. 11731 (SI); deYavi, Ruta Nacional 40, de La Quiaca a Santa Catalina, 3640 m, 28 $8^{\prime} 11^{\prime \prime S}, 65^{\circ} 44^{\prime} 19^{\prime \prime W}, 19$ febrero 2011, Zuloaga et al. 13081 (SI). Mendoza: Departamento Las Heras, Parque Provincial Aconcagua, 3786 m, 69 $89^{\prime} \mathrm{S}, 86^{\circ} 90^{\prime} \mathrm{W}$, 26 enero 2011, Barros A. 38, 39, 40 (SI). Salta: Departamento Santa Victoria, ruta 7, km 30, cerca de Pueblo Viejo, 6 febrero 2003, Sanso M. \& Xifreda C. 211 (SI); camino de Abra Fundición a Nazareno, $4010 \mathrm{~m}, 22^{\circ} 29^{\prime} 1 " \mathrm{~S}, 6^{\circ} 6^{\prime} 30^{\prime \prime} \mathrm{W}, 21$ febrero 2011, Zuloaga et al. 13182 (SI).

\section{Festuca distichovaginata Pilg.}


ARGENTINA. Salta: Departamento Santa Victoria, La laguna, cerro del Cajón, orilla riachos, 3900 m, diciembre 1913, Rodríguez F. M. 1324 (2 pliegos) (LIL). Tucumán: Departamento Tafí, Cumbres Calchaquíes, 30 enero 1933, Parodi L. R. 10849 (LP); Cerro Negrito, 4100 m, 26 febrero 1949, Spane B. 6117 (SI); El Pelao, 4000 m, 17 marzo 1912, Rodríguez F. M. 440 (2 pliegos) (LIL).

\section{Festuca fiebrigii Pilg.}

ARGENTINA. Catamarca Departamento Andalgalá, abundante en pantanos, 1915, Jörgensen P. 1655 (SI); summit of cuesta El Portezuelo, 5 febrero 1943, Bartlett H. H. 19606 (SI); Belén, weg Antofagasta de la Siera, Laguna Blanca/Corral Blanco, 3400-3600 m, 16 febrero 1995, Ruthsatz 9354 (SI); Paclin, ruta provincial 9, empalme rutas provinciales 9 y 1, cuesta del ringuil, $1300 \mathrm{~m}, 24^{\circ} 49^{\prime} \mathrm{S}$, 65 52 'W, 12 diciembre 2008, Ponce M. M. 108 (SI). Córdoba: Departamento Río Cuarto, Entre Punilla (San Luis), sierras bajas, matorral de Eupatorium buniifolium, 942 m, 33¹0'17"S, 65²'14"W, 29 noviembre 2008, Biganzoli F. et al. 2116 (SI). Jujuy: Departamento Tumbaya, Chilcayo, finca de

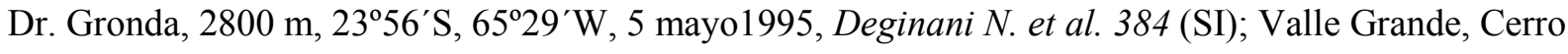

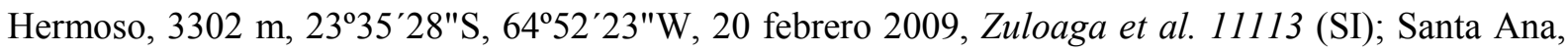
29 febrero 1940, Burtkart A. y Néliada S. Troncoso 11667 (SI); cerros desde 3000 m, 29 febrero 1940, Burtkart A. y Nélida S. Troncoso 11600, 11644 (SI); entre León y Nevado de Chañi: Pie de la Cuesta, 2600 m, 6 marzo 1963, Fabris H. A. 3962 (LP). Salta Departamento Rosario de Lerma, ruta 51,

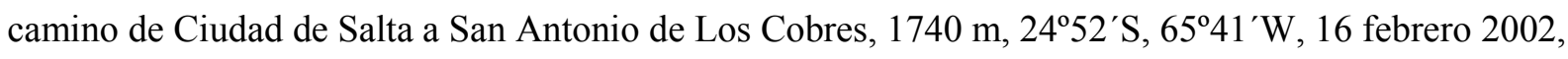
Cialdella A. et al. 371 (SI); Chicoana, Ruta Provincial 33, entre San Fernando de Escoipe y Escoipe, $25^{\circ} 10^{\prime} 42^{\prime \prime S}, 65^{\circ} 48^{\prime} 58^{\prime \prime W}, 15$ febrero 2007, Zuloaga et al. 9412 * (SI). San Juan: Departamento Valle Fértil, Sierra. De Elizondo, cerros y alrededores, 1700 m, 17 diciembre 1987, Múlgura M. 816, 874 (SI). San Luis: Departamento Coronel Pringles, La Carolina, 8 noviembre 1940, Burkart A. 10790 *

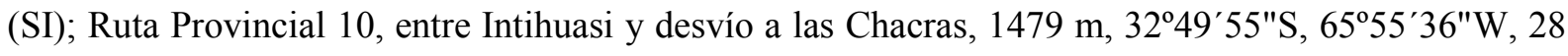
noviembre 2008, Biganzoli, F. 1821 (SI); Pedernera, al Morro Ca del Guanaco, 19 diciembre 1995, Scappini R. E. et al. 2053 (SI). Tucumán Departamento Tafí, Ruta 307, camino de Tafí del Valle a Amaicha el Valle, El Infiernillo, 2970 m, $26^{\circ} 45^{\prime} \mathrm{S}, 65^{\circ} 45^{\prime} \mathrm{W}, 10$ febrero 2002, Cialdella A. et al. 154 (SI); Infiernillo, 2850 m, 30 diciembre 1971, Krapoickas A. y C. L. Cristobal 20491 (SI).

\section{Festuca fimbriata Nees}

ARGENTINA. Corrientes: Departamento Santo Tomé, Garruchos, 22 octubre 1954, Burkart A. 19654 (2 láminas) (SI); Ruta 37, 5 km E de Gdor. Virasoro, 14 noviembre 1974, Schinini A. y Carnevali R. C. 10523 (SI); Arroyo Chimiray y Ruta 40, 8 octubre 1976, Quarín C. 3409 (SI). Misiones: Departamento Apóstoles, escuela Agrotécnica, 1 mayo 1977, Cabrera A. L. 28766 (SI); cerca de Azara, 15 noviembre 1978, Hunzinker J. 9958 (SI); Ruta Provincial 40 y Arroyo Chimiray, 110 m, 16 octubre 2000, Zuloaga F. O. y Morrone O. 15631 (SI). 
BRASIL. Río de Janeiro: Región de Itatiaya, Prateleiras, 1 marzo 1937, Brade 577 (SI). Río Grande do Sul: sin región, apartados da Rocinha, 18 enero 1950, Barreto 45452, 45466 (LIL); Campo Erê, Bog, $6 \mathrm{~km}$ west of Campo Erê, $26^{\circ} 22$ 'S, $53^{\circ} 6^{\prime} \mathrm{W}, 7$ diciembre 1964, Smith L. B.\& Klein R. M. 13674 (SI). Minas Gerais: Región de Brasilia, Minas Gerais, Smith L. B. \& Klein R. M. s.n. (LIL). Santa Catharina: Región de Santa Catarina, $27 \mathrm{~km}$ south of Lajes, Slough, Marinhos road, 20 diciembre 1971, Rambo B. 15936 (SI); Sin estado, sin región, sin localidad, diciembre 1957, Widgrem 7155 (BAA).

\section{Festuca gracillima Hook. $f$.}

a. var. gracillima

ARGENTINA. Santa Cruz: Departamento Güer Aike, $116 \mathrm{~km} \mathrm{SE}$ of Turbio along Hwy 40 towards Río Gallegos, 197 m, 515'ㄱ, 58"S, 7046'29"W, 5 febrero 1978, Ambrosetti, J. A. et al. s.n.T.B.P.A.-

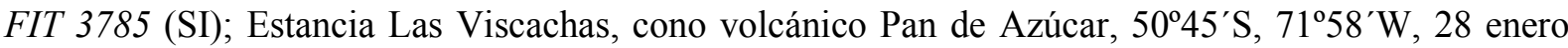
1977, Arroyo et al. s.n. T.B.P.A. 2409, 2552 (SI); Estancia las Viscachas, cerro Las Viscachas, laderas inferíores, 5046 ${ }^{\prime} \mathrm{S}, 7^{\circ}{ }^{\prime}{ }^{\prime} \mathrm{W}, 8$ febrero 1978, Boelcke, O. et al. s.n.T.B.P.A. 2963 (SI); Estancia Sofía, $3 \mathrm{~km} \mathrm{~W}$ del casco, $350 \mathrm{~m}, 5^{\circ} 44^{\prime} \mathrm{S}, 7^{\circ} 20^{\prime} \mathrm{W}, 9$ enero 1933, Castellanos, A. 7575 (SI); Cordillera Chica, 800 m, 51 ${ }^{\circ} 27^{\prime} \mathrm{S}, 72^{\circ} 6^{\prime} \mathrm{W}, 14$ enero 1976, Méndez, E. 1060 (SI); Ruta Nacional 40, Estancia La Carlota, 25 noviembre 2012, Zuloaga, F. et al. 14090* (SI). Tierra del Fuego e Islas del Atlántico Sur: Departamento Río Grande, estancia Los Flamencos $46 \mathrm{~km} \mathrm{~W}$ of Río Grande, $53^{\circ} 42^{\prime} \mathrm{S}, 68^{\circ} 9^{\prime} \mathrm{W}$, 28 diciembre 1970, Goodall, P. 2815 (SI); Estancia José Menendez on flat Estancia Punta María hills south side roads, 6 enero 1971, Goodall, P. 3086 * (SI); Estancia Cullen, Alfa Camp near Cabo Espiritu Santo, northernmost tip of Argentine, Tierra del Fuego, 17 noviembre 1971, Moore, D. M. et al. 2493 (SI); Ushuaia, Lago Fagnano, 1 marzo 1917, Bonarelli s.n. (SI); Lago Camí, 1 abril 1927, Guiñazú, J. R. 229 (SI); Plantae Magellanicae, 4 enero 1971, Moore, D. M. \& R. N. Goodall 300 * (SI).

CHILE. XII Región: Provincia Tierra del Fuego, $75 \mathrm{~km} \mathrm{Sw}$ of road to Caleta Josefina cerca $10 \mathrm{~km} \mathrm{~N}$

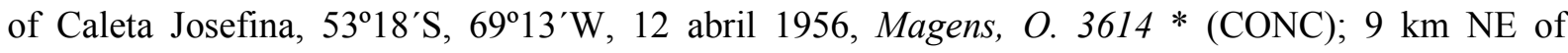
Porvenir, 53 $15^{\prime} \mathrm{S}, 7^{\circ} 17^{\prime} \mathrm{W}, 14$ diciembre 1971, Moore, D. M. et al. 125 (SI); Provincia Última Esperanza, Estancia Cerro Castillo, 51 ${ }^{\circ} 16^{\prime} \mathrm{S}, 7^{\circ} 27^{\prime} \mathrm{W}, 16$ enero 1977, Latour, M. C. et al. s.n. T.B.P.A. 1671 (BAB); Parque Nacional Torres del Paine, 17 enero 2003, Peterson, P. M. et al. 17100 (SI); Salto grande del Paine, 51 ${ }^{\circ} 4^{\prime} \mathrm{S}, 73^{\circ} 0^{\prime} \mathrm{W}, 24$ diciembre 1969, Pisano, E. 2368 (CONC); Última Esperanza, Sierra Cazador, Cerro el Castillo, 900 m, 51 ${ }^{\circ} 10^{\prime} \mathrm{S}, 72^{\circ} 28^{\prime} \mathrm{W}, 9$ febrero1962, Ricadrdi, M. \& O. Matthei 483 (CONC); Cerro Castillo, $150 \mathrm{~m}, 51^{\circ} 17^{\prime} \mathrm{S}, 72^{\circ} 20^{\prime} \mathrm{W}, 16$ febrero 1988, Rúgulo $1157^{*}$ (SI); Provincia de Magallanes, Manantiales, 8 m, 52 32'S, 69 20’W, 27 noviembre 1956, Magens, O. \& Matthei 3447 (CONC).

b. var. glacialis Rúgolo \& Nicora 
ARGENTINA. Santa Cruz: Departamento Güer Aike, Estancia Las Viscachas, Cerro Puerto La Piedra, faldeos SE, 1325 m, 50 $43^{\prime} \mathrm{S}, 72^{\circ} 8^{\prime} \mathrm{W}, 26$ enero 1977, Arroyo et al. s.n. T.B.P.A. 2535* (CONC, SI); Estancia Stag River, meseta La Torre, cerro Punta Gruesa, 910 m, 51 ${ }^{\circ} 32^{\prime} \mathrm{S}, 72^{\circ} 5^{\prime} \mathrm{W}, 24$ enero 1978, Roig, F. et al. s.n. T.B.P.A. 3063 (SI); Estancia Stag River, meseta La Torre, cerro Punta Guresa, 5132'S, 725'W, 25 enero 1978, Roig, F. et al. T.B.P.A. 2946, 2978 (SI).

CHILE. XII Región: Provincia Magallanes y Antárctica Chilena, Parque Nacional Torres del Paine, Cerro Agudo, 650 m, 5049’S, 733' W, 15 enero 1987, Arroyo, M. .T. K. \& F. Squeo 870059 (CONC); Última esperanza, Estancia Cerro Castillo, $51^{\circ} 20^{\prime} \mathrm{S}, 72^{\circ} 37^{\prime} \mathrm{W}, 18$ enero 1977, Lantour, N.C. et al. s.n. T.B.P.A. 1755 (SI); Ultima Esperanza, Las Cumbres, Baguales, $550 \mathrm{~m}, 51^{\circ} 40^{\prime} \mathrm{S}, 72^{\circ} 30^{\prime} \mathrm{W}, 6$ febrero 1962, Ricardi, $M$ \& O. Matthei 391 (SI).

\section{Festuca hieronymi Hack.}

ARGENTINA. Córdoba: Departamento Colón, Sierra Chica (flada E): cerca de Río Ceballos, en el camino a El Cuadro., Hunziker A.T. 10123 (SI); Santa Rosa de Calamuchita, estancia El Catre, 1700 m, diciembre 1988, Reichart A. R. 1770 (SI); Cerros de Copina, 13 enero 1940, Burkart A. 10118 (SI); Pampa de Achala, 13 enero 1940, Burkart A. 10170 (SI); Pampa de Achala, 15 enero 1940, Burkart A. 7257 * (SI); La Resurrección, cerros a 700 m de alto, no abajo, 700 m, 28 diciembre 1935, Burkart A. 20790 (2 láminas) (SI); sierras entre los gigantes y Taringa, 5 diciembre 1958, Burkart A. 7228 (2 láminas) (SI); Pampa de Achala, 29 diciembre 1935, Burkart A. 1042, 1043 (SI); Ascochinga, 21 diciembre 1938, Giardelli M. L. 596 (SI); La Cascada, Sierra Chica, camino de Ascochinga a La Cumbre, 13 noviembre 1936, Giardelli M. L. 9476 (SI); Ascochinga, 30 enero 1938, Nicora E. 1131 (2 láminas) (SI); sin localidad, 13 noviembre 1936, Nicora E. 791 (SI); viaje a la Pampa de Achala, Millán A. R. s.n. (SI). Salta: sin departamento, Cuesta del Obispo. La Herradura, 3100 m, 24 enero 1995, Hunzinker J. 13190 (SI).

\section{Festuca hypsophila Phil.}

ARGENTINA. Catamarca: Departamento Antofagasta de la Sierra, Antofagasta de la Sierra, $3800 \mathrm{~m}$, $26^{\circ} 5^{\prime} \mathrm{S}, 6^{\circ} 25^{\prime} \mathrm{W}, 10$ diciembre 1998, Rodríguez, M. F. 7 (SI); Tinogasta, Vega al este de Chaschuil, 2900 m, 14 enero 1993, Haene, E. 1197 (SI); Andes, E of paso de San Francisco cerca 18 km on Hwy 60 to Fiambala, 4010 m, 26055'20"S, 68º' 41"W, 16 Marzo 2006, Peterson, P. M. et al. 19368 (SI). Jujuy: Departamento Humahuaca, Mina Aguilar, cerro Aguilar, arriba de la mina cerca de la toma de agua, 4670-4730 m, 4 marzo 1983, Hunziker J. H. 10604*(SI); Mina Aguilar, 4500 m, 17 abril 1965, Fernández, L. 1031 (SI); Rinconada, Mina Pirquita, 4300 m, 1 febrero 1964, Schwabe, A. 811 (LIL); Tumbaya, refugio Casa Moncha, por la quebrada del río, $4281 \mathrm{~m}, 24^{\circ} 1^{\prime} 6 " \mathrm{~S}, 65^{\circ} 46^{\prime} 54^{\prime \prime} \mathrm{W}, 21$ enero 2012, Zanotti, C. A. \& M. A. Suescún 309 (SI); Valle Grande, Caspalá, 1 marzo 1940, Burkart, A. et al. 11901 (SI); Yavi, Quebrada de Toquero, 3600 m, 21 febrero 1963, Cabrera, A. L. et al. 15367 (LP). La Rioja: Departamento Vinchina, Refugio El Peñón, vega 32, 3550-3600 m, 30 enero 1995, 
Ruthsatz 9094 (SI); El Peñón, Precordillera, 3600 m, 2 febrero 1947, Hunziker, J. H. 2134 (SI); Vinchina, entre Jagué y el paso Pircas Negras, por el camino a Chile, 3575 m, 7 febrero 1999, Biurrun, F. et al. 5512*, 5516, 5529 (SI). San Juan: Departamento Iglesia, reserva de San Guillermo, vega de Santa Rosa, 18 enero 1983, E. Nicora et al. 8583 (SI).

CHILE. II Región: Provincia Antofagasta, 7 km NW of Estación de Cebollar on HWY 21 towards Ollagüee along Salar de Ascotán, 3765 m, 2129'59"S, 68²3’ 41"W, 21 febrero 2001, Peterson, P. M. et al. 15588 (SI); Provincia El Loa, $78 \mathrm{~km} \mathrm{~N}$ of Calama on HYW 21 towards Ollagüe, $3300 \mathrm{~m}$, 21 $1^{\circ} 56^{\prime} 33,1^{\prime \prime S}, 68^{\circ} 31^{\prime} 46,7^{\prime \prime W}, 23$ marzo 2001, Peterson, P. M. et al. 15610 (CONC); 28 km NW of

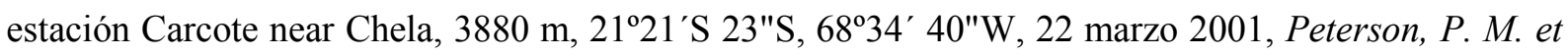
al. 15596 (SI); Provincia Iquique, Cerro Columtusca, 4500 m, marzo 1926, Werdermann, E. 1075 * (SI). III Región: Provincia Copiapó, ojo de Maricunga, quebrada de Paipote, 2720 m, 1 febrero 1944, Muñoz, C. 3969 (SGO).

\section{Festuca kurtziana St.-Yves}

ARGENTINA. Mendoza: Ruta 222, en dirección a las Leñas, $3 \mathrm{~km}$ antes de Las Leñas, $2130 \mathrm{~m}, 9$ enero 2012, Sede, S. M. \& S. Denham 378a* (SI); Ruta 222 en dirección a Valle Hermoso, entre Los Molles y el mirador, 2985 m, 9 enero 2012, Sede, S. M. \& S. Denham 398 (SI); Malargüe, Valle Hermoso, 28 enero 1963, Boelcke, O. et al. 10280 (SI); Paso Pehuenche, puesto gendarmería, 21 enero 1963, Boelcke, O. et al. 10402 * (SI, BAA); Cerros al norte de Calmucó, 1920 m, 16 febrero 1942, Burkart, A. et al. 13908,13911 * (BAA); Andes, Río Salado headwaters, Valle de Las Leñas, cerca 36 km NW of Las Lenas on Hwy 222, NW of Malargüe 65 km, 2740 m, 35 5 5'42"S, 708'11"W, 5 marzo 2006, Peterson, P. M. et al. 19193, 19192 (SI); Arroyo León, Valle Noble, 1630 m, 35³8'44"S, 70¹1'23"W, 9 diciembre 2003, Prina, A. et al. 2197 (SI); Ruta Provincial 224, orilla del Río Pichi, 2160 m, 355' $25^{\prime \prime S}, 70^{\circ} 16^{\prime} 46^{\prime \prime} \mathrm{W}, 16$ febrero 2003, Prina, A. et al. 1980 (SI); Ruta 222, en dirección a Las Leñas, $3 \mathrm{~km}$ antes de Las Leñas, ladera este de cerros bajos, $2130 \mathrm{~m}, 35^{\circ} 11^{\prime} 44$ "S, 70 $1^{\prime} 48^{\prime \prime} \mathrm{W}, 9$ enero 2012, Sede, S. et al. 378 (SI); Ruta 222 en dirección a Valle Hermoso, entre Los Molles y el mirador, arroyo y mallín en loma pedregosa, $2985 \mathrm{~m}, 35^{\circ} 6^{\prime} 33^{\prime \prime} \mathrm{S}, 7^{\circ} 8^{\prime} 33^{\prime \prime} \mathrm{W}, 9$ enero 2012, Sede, S. et al. 398 (SI); San Rafael, Valle Atuel, 2400 m, no date, Bocher, T. W. et al. 1512 (BAA); Calmucó, 2400 m, 14 febrero 1942, Covas 87 (BAA); Vegas oeste hotel El Sosneado, 2200 m, 19 enero 1973, Lagiaglia, H. A. 1523 (LP); San Carlos, camino Laguna del Diamante, 2 febrero 1950, Boelcke, O. et al. 4066 (BAA); Camino a Laguna Diamante, 6 km W refugio militar Gral. Alvarado, 17 enero 1963, Boelcke, O. et al. 9979 (SI, BAA); Laguna del Diamante, no date, Dubcovsky 619 (BAB); Reserva Provincial Laguna del Diamante, 2675 m, 8 diciembre 2009, Prina, A. et al. 3484, 3579 (SI); Arroyo Paramillo, camino a Laguna del Diamante, Cordillera de los Andes, 2500 m, enero 1950, Soriano, A. 4067 (BAA); Tunuyán, sin localidad, 3225 m, 21 marzo 1935, Ruiz Leal 3140 (BAA); desconocido, sin localidad, 2600 m, no date, Gerth 125 (SI). Neuquén: Departamento Aluminé, Ruta 23, a 46 km aprox. de Pilolil, hacia Junín de los Andes, 1075 m, 18 enero 2015, Denham, S. 426 (SI); Minas, 
extremo norte laguna Varvaco, campos Cajón del Varvaco, 6º $17^{\prime} \mathrm{S}, 70^{\circ} 37^{\prime} \mathrm{W}, 31$ enero 1970, Boelcke, O. et al. 14126 (SI); Chos Malal, Cajón del Cruce, 2500 m, 36²43'S, 70²3’ W, 27 enero 1964, Boelcke, O. et al. 11268 (SI); Ruta 37, base del cerro Waile, entre la ruta y refugio, $2190 \mathrm{~m}, 31$ enero 2015, Denham, S. 368 (SI).

CHILE. Región Metropolitana: Provincia Santiago, embalse El Yeso, 2700 m, 19 marzo 1986, Araya, F. s.n. (CONC); Embalse El Yeso, 2700 m, 19 marzo 1986, Araya, F. s.n. CONC 72573 * (CONC); Embalse El Yeso, 2500 m, enero 1986, Dubcovsky, J. \& A. Martínez 252 (BAB); End of Yeso Valley, 2450 m, 334ㅇ's, 705'W, 16 febrero 1967, H. et B. Mooney 535 (CONC); Río Yeso, above Embalse del Yeso, around Termas del Plomo, 2645 m, 13 enero 2002, Soreng, R. 7158

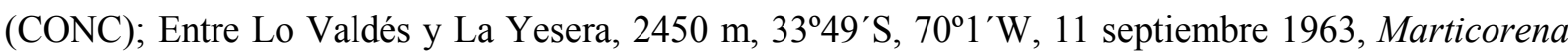
\& Matthei 871 (CONC). VII Región: Provincia Talca, comuna San Clemente, Paso Pehuenches, 2200-2400 m, enero 2005, Luebert, F. et al. 2304 (CONC); Entre Paso Pehuenches y Laguna del Maule, 36은 $\mathrm{S}, 70^{\circ} 25^{\prime} \mathrm{W}, 13$ febrero 1963, Marticorena \& Matthei 983 (CONC); Provincia Curicó, Camino de Curicó a Paso Vergara, 2350 m, 35²4'S, 70³7’ W, 11 marzo 1967, Marticorena \& Matthei 981, 1058 (CONC); Curicó, Río Tene, 31 diciembre 1970, Zöllner, O. 4996 (CONC); Provincia Linares, Cajón Troncoso, 1870 m, 36²0’S, 7045’W, 27 enero 1961, Schlegel, F. 3696 (CONC).

\section{Festuca lasiorrhachis Pilg.}

ARGENTINA. Jujuy: Departamento Tilcara, camino de Abra del potrero a Molulo, $2810 \mathrm{~m}$, 233ㄴ'57"S, 6507'2"W, 10 febrero 2010, Zuloaga et al. 11663 (SI); Cachi, cuesta del Obispo, $200 \mathrm{mts}$ pasando piedra del Molino, $3360 \mathrm{~m}, 27^{\circ} 10^{\prime} 54$ "S, 65 $51^{\prime} 23$ "W, 16 febrero 2011, Zuloaga et al. 12955 (SI). Salta: Departamento Chicoana, Ruta Provincial 33, de Piedra del Molino a Salta, Valle Encantado, 3130 m, 2510'53"S, 6551'4"W, 3 febrero 2005, Zuloaga et al. 8459 (SI).

CHILE. II Región Provincia de Antofagasta, vicinity of Aguada de miguel Díaz, $24{ }^{\circ} 35$ 'S 1-4 diciembre 1925, Johnston I. M. $5403 *$ (BAA).

\section{Festuca lilloi Hack.}

ARGENTINA. Salta: Departamento desconocido, La Laguna, cerro del cajón, 3900 m, Rodríguez D. 1326 (SI). Tucumán: Departamento Chicligasta, estación Santa Rosa, puerto la Cascada, 3800 m, 16 marzo 1924, Venturi S. 5317 (SI); estación Santa Rosa, puerto la Cascada, 3400 m, 13 marzo 1924, Venturi S. 5298 *, 9580 (LIL); Tafí, Sierras Calchaquíes, peñas Azules, 3400 m, 29 enero 1933, Burkart A. 5 (SI); Sierras Calchaquíes, peñas Azules, 3400 m, 30 enero 1933, Burkart A. 3508 (2 pliegos) (SI); La Queñoa (Cumbre San José), 2800 m, 1 marzo 1933, Díaz 44 03-2009 (LIL); D. Valle, 2300 m, Hueck 417 (SI); Infiernillo, 3100 m, 24 mayo 1959, Türpe A. 3209 (LIL); Dpartamento de Trancas, camino a Lara, 3247 m, 27 marzo 2009, Slanis A. c. et al. 11138 (SI); ruta de hualinchay a 
Tolombón, a $25 \mathrm{~km}$ de Hualinchay, campos e altura, 3160 m, 15 febrero 2008, Zuloaga F. O. et al. 3149 (SI); desconocido, cumbre e Malamala, 6 abril 1904, Lillo M. 10063 (LIL).

\section{Festuca magellanica Lam.}

ARGENTINA. Chubut: Departamento Tehuelches, $\mathrm{km} 8 \mathrm{~W}$ of Río Pico on road towards Lago Vintter, 815 m, 44 $8^{\prime} 33,1^{\prime \prime S}, 7^{\circ} 26^{\prime} 41,7^{\prime \prime} \mathrm{W}, 26$ enero 2003, Peterson, P. M. et al. 17294 (SI). Neuquén: Departamento Lácar, Cordón del Chapelco, Cerro Las Tetas, desde el centro de esquí, 1850 m, 19 enero 2015, Denham, S. 438 (SI). Santa Cruz: Departamento Güer Aike, valle superior del río Turbio, Cordillera Chica, coerro Punta alta, $1100 \mathrm{~m}, 51^{\circ} 26^{\prime} \mathrm{S}, 72^{\circ} 6^{\prime} \mathrm{W}, 5$ febrero 1978 , Ambrosetti \& Méndez s.n. T.B.P.A.-FIT 3763 (SI); Estancia La Verdadera Argentina, 50 51'S, 72¹4' W, 24 enero 1977, Arroyo, S. et al. s.n. T.B.P.A. 2341, 2063 (SI); Estancia Las Viscachas, de Riques, 5045'S, $72^{\circ} 12^{\prime} \mathrm{W}, 31$ enero 1977, Arroyo, S. et al. s.n. T.B.P.A. 2694 (SI); Road to Punto Arenas (Magallanes), $32 \mathrm{~km}$ southest of town of Río Gallegos, wet sandy loam and mud of shore of small lake, $30 \mathrm{~m}, 4$ enero 1939, Goddspeed, T. H. 24088, 24247 (SI); 116 km SE of El Turbio along Hwy 40 towards Río Gallegos, 197 m, 51 $54^{\prime} 58,8^{\prime \prime S}, 70^{\circ} 46^{\prime} 29,6 " \mathrm{~W}, 17$ enero 2003, Peterson, P. M. et al. 17098 (SI); Estancia La Sofía, $83 \mathrm{~km}$ SE of El Turbio on Hwy 40 towards Río Gallegos, 142 m, 51²59'5,4"S, 71'1248'W, 18 enero 2003, Peterson, P. M. et al. 17107 (SI); Estancia La Carlota, sección San Elías, 51 $23^{\prime} \mathrm{S}, 71^{\circ} 24^{\prime} \mathrm{W} 18$ enero 1978, Roig et al., T.B.P.A.-FIT. 2734 (SI); Lago Buenos Aires, 77 km SW of Los Antiguos or road towards Paso Roballos, 1478 m, 47 $1^{\prime} 29^{\prime \prime S}, 71^{\circ} 48^{\prime} 25,1^{\prime \prime W}, 24$ enero 2003, Peterson, P. M. et al. $17271^{*}$ (SI). Tierra del Fuego e Islas del Atlántico Sur: Departamento Río Grande, Estancia Los Flamencos, 46 km W of Río Grande, 534' $\mathrm{S}, 68^{\circ} 9^{\prime} \mathrm{W}, 4$ enero 1971, Moore, D. M. \& R. N. Goodall $302 *(\mathrm{SI})$.

CHILE. XII Región: Provincia Antártica Chilena, Isla Navarino, al E de Puerto Williams, 18 febrero 1987, F. Schlegel 8192 (CONC); Provincia Tierra del Fuego, Lago Blanco, Cerro Cuchillo, 665 m, 12 marzo 1968, Moore, D. M. 22256 (SI); Caleta Josefina, 28 enero 1962, Ricardi, M. \& O. Matthei 168 (CONC); Provincia Ultima Esperanza, Estancia Cerro Castillo, km 30, Rincon Negro 5. 400 m., $51^{\circ} 0^{\prime} \mathrm{S}, 72^{\circ} 16^{\prime} \mathrm{W}, 16$ diciembre 1975, Boelcke, O. et al. s.n. T.B.P.A. 628 (SI); Provincia Ultima Esperanza, Estancia Cerro Castillo, Boelcke, O. et al. s.n. T.B.P.A. 420 p.p. (SI), 496 (SI), 818 (SI), 611 (CONC, SI), 643 (SI); Parque Nacional Torres del Paine, Cerro Daudet, 730 m, 18 enero 1987, Arroyo, M. T. K. \& F. Squeo 870112 (CONC), 870152 (CONC); Sierra de los Baguales, Estancia LA cumbre, 900 m, 29 enero 1987, A. Landero 791 (CONC).

\section{Festuca monticola Phil.}

ARGENTINA. Neuquén: Departamento Picunches, cerca del Refugio del Cerro Colorado, 1550 m, 7 febrero 1944, Diem 765*, 769* (CONC, SI); Huiliches, ladera S Volcán Lanín, 1300-1600 m, 17 febrero 1974, Correa, M. et al. 5803, 5976 (CONC). 
CHILE. VIII Región: Provincia Biobío, Parque Nacional Laguna del Laja, sendero desde los Zorros

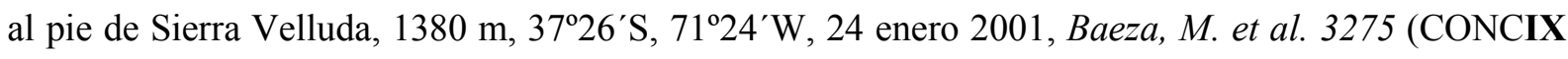
Región: Provincia Temuco, Volcán Llaima, 1500 m, 1 febrero 1927, Werdermann, E. $1268 *$ (SI). X Región: Provincia Chiloe, Osorno, cráter colorado, 1260 m, 13 febrero 1991, Ruthsatz, B. 7810 * (SI). XII Región: Provincia Ultima Esperanza, seno Ultima Esperanza en Lote Sanchez costa del Río

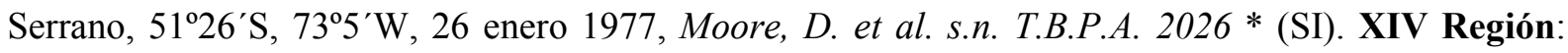
Provincia Valdivia, Cordillera Pelada, Cerro Mirador, 1040 m, 40¹0’S, 73²9’ W, 1 febrero 1965, Marticorena, C. \& O. Matthei 1191, 1201, 5270/74 (CONC).

\section{Festuca nardifolia Griseb.}

ARGENTINA. Jujuy Departamento Caspalá, cumbres en la falda occidental, 4600 m, 3 febrero 1940, Burkart A. et. al. 11847 (SI 11847); Mina Aguilar, 4650 m, 13 enero 1948, Cabrera A. L. 9210 * (BAB); Mina Aguilar, toma del agua, 4900 m, 15 febrero 1959, Fabris H. A. \& J. Marchioni. 1839 * (BAA); Mina Aguilar (arriba), 4700 m, 9 febrero 1960, Meyer T. et. al. 21216 (LIL 93942); Doctor Manuel Belgrano, sendero de Ovejaría al Refujio Militar, 3931 m, 20 enero 2012, Zanotti C. A. \& M. A. Suescún 252 (SI 160513). Salta: Departamento San Antonio de Los Cobres, Cuesta del Acay, 1 febrero 1944, Cabrera A. L. 8342 (BAA); Deprtamento de Santa Victoria, Abra de Lizoite: vega 112, 4410 m, 7 marzo 1997, Erschb Ru. 9831 * (SI 152090). San Juan: Departamento Iglesia, Reserva San Guillermo, Vega Co. Imán, 3900 m, 23 febrero 1981, Cajal J. L. et. al. 117 (SI 123146). Tucumán: Departamento Tafí del Valle, cumbres Calchaquíes, 4500 m, 1 enero 1908, Castillón L. 7961 (LIL 44088); Sierras Calchaquíes, quebrada del Matadero, 4200 m, 1 enero 1963, de la Sota 2731 (BAA); Laguna Nostra, 2 enero 1978, Halley 902 (LIL 559380); cumbres Calchaquíes, 4600 m, 12 febrero 1907, Lillo M. 19545 (SI 096562); cumbre Nevado San José (Camino a las algunas), 4400 m, 1 abril 1933, Olea I. 9451 (LIL 732); región montañosa entre San Javier, cumbres Calchaquíes y Amaicha (Valle Calchaqui), 4400 m, 30 enero 1933, Parodi L. R. 10820 (BAA); Calchaquíes, Cerro Isabel, 4500 m, 17 febrero 1952, Sparre 9632 (LIL 474278).

\section{Festuca nemoralis Türpe}

ARGENTINA. Jujuy Departamento Capital, Yala, cerros, 19 febrero 1940, Burkart A. y N. Troncoso 11313 (SI); Cerros del Yala, 19 febrero 1940, Burkart A. y N. Troncoso 11302 (SI); Laguna de Yala, 12 febrero1980, Cabrera A. L. et al. 31547 (SI); Yala, laguna Rodeo, 2200 m, 21 marzo1986, Guaglianone E. R. et al. 919 (SI); Laguna de Yala, 2050 m, 22 febrero1983, Hunzinker J. H. et al. 2007 (SI); Parque Nacional Calilegua, alto Calilegua., 2550 m, 21 enero 1981, Iudica y Fullana 10325 (2 láminas) (SI); Parque Nacional Aguas Blancas, 2815 m, 25 febrero1986, Ludica y Fullana 391 (SI); Lagunas de Yala, 2500 m, 16 febrero1987, Nicora E. et al. 217 (SI); Laguna de Yala, 16 enero 1988, Zuloaga F. y N. B. Deginani 8719 (SI); Valle Grande, Altos de calilegua, 2600 m, 17 febrero 1995, Deginani N. et al. 3542 (SI). 
23. Festuca ovina L. subsp. tenuifolia (Sibth.) Čelak.

ARENTINA. Santa Cruz: Departamento Güer Aiken, Estancia Stag River, meseta Latorre, Cerro Punta Gruesa, 28 noviembre, Méndez 1000 (SI).

\section{Festuca pallescens (St.-Yves) Parodi}

ARGENTINA. Chubut: Departamento Cushamen, Leleque, 13 enero 1947, Soriano, A. 2345 (SI); Futaleufú, Cerro Cuche, 28 enero 1947, Soriano, A. 2502 (SI); Lago El Guacho, 4 febrero 1989, Nicora, E. G. 9509 (SI); Río Senguer, Valle Huemules, 22 enero 1948, Soriano, A. 3182, 3183 (SI); Tehuelches, entre Río Pico y Lago Vintter, 16 enero 1948, Soriano, A. 3063 (SI); 8 km W of Río Pico on road towards Lago Vintter, 815 m, 26 enero 2003, Peterson, P. M. et al. 17288 (SI); Lago Los Niños, 20 enero 1992, Nicora, E. G. 9609 (SI); Lago Vintter en la confluencia con carrión Cufi, 28 enero 1992, Nicora, E. G. 9672 (SI). Neuquén: Departamento Lácar, Cordón del Chapelco, Estancia Miralejos, sendero a la laguna La Kika, 1350 m, 20 enero 2015, Denham, S. 449 (SI). Río Negro: Departamento Bariloche, estancia San Ramón, 14 diciembre 1962, Vallerini, J. 275 (SI); Parque

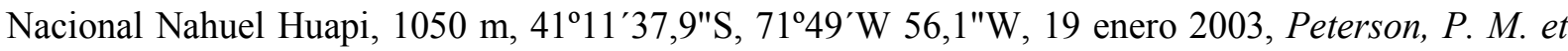
al. 17347 (SI); Pilcaniyeu, Pasando el Río Pichi Leufú, 23 noviembre 1967, Correa, M. et al. 1463 (SI); 6 km de Pilcaniyeu camino a Bariloche, 28 enero 1944, Nicora, E. G. 3637 *, 3695 (SI); Valcheta, meseta de Somuncurá, Cerro Corona a Laguna Paraguay, 1450 m, 10 enero 2002, Troiani, H. \& P. Steibel. 15189 * (SI). Santa Cruz: Departamento Deseado, colonia General Las Heras, 17 enero 1914, colector desconocido s.n. (SI 096586); $10 \mathrm{~km}$ west of Puerto Deseado, $20 \mathrm{~m}, 29$ septiembre 1938, Goodspeed et al. 23860 (SI); $46 \mathrm{~km} \mathrm{~N}$ of 28 de Noviembre on Hwy 40, $251 \mathrm{~m}$, 51 ${ }^{\circ} 13^{\prime} 6,7^{\prime \prime} \mathrm{S}, 72^{\circ} 13^{\prime} 5,8^{\prime \prime} \mathrm{W}, 18$ enero 2003, Peterson, P. M. et al. 17137* (SI); Lago Buenos Aires, 83

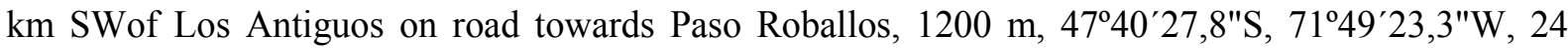
enero 2003, Peterson, P. M. et al. 17250 (SI); Río Chico, 27 km W of Hwy 40 on Hwy 35 towards Estancia Tucu Tucu, 646 m, 48 15'6,3"S, 720'15,5"W, 22 enero 2003, Peterson, P. M. et al. 17200 (SI); km $27 \mathrm{~S}$ of Bajo Caracoles on HWY 40, 688 m, 47 38'20,7"S, 7048'7,4"W, 23 enero 2003, Peterson, P. M. et al. 17231 * (SI); Güer Aike, Estancia La Verdadera Argentina cerro La Virgen, ladera inferíor S, 500 m, 50 50'S, 72 $41^{\prime} \mathrm{W}, 17$ enero 1977, Arroyo et al. s.n.T.B.P.A. $2121^{*}$ (SI); desconocido, platae patagonie, 20 noviembre 1929, Donat s.n. (SI 15279).

CHILE. XI Región: Provincia Capitan Prat, lago Esmeralda, 510 m, 47 $17^{\circ} \mathrm{S}, 72^{\circ} 36^{\prime} \mathrm{W}, 15$ enero

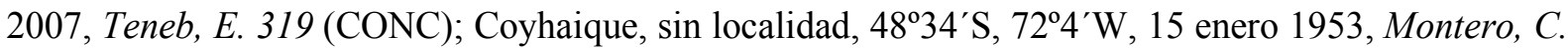
5482, 5505 (CONC); Cañadón Grande, junto al camino, 15 m, 52 ${ }^{\circ} 14$ 43"S, $69^{\circ} 14$ 17"W, 29 noviembre

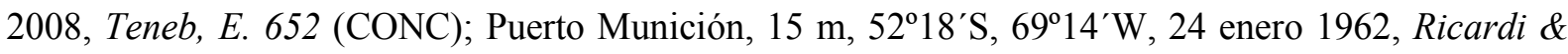
Matthei 61, 430 (CONC); Comuna San Gregorio, Parque Nacional Pali Aike, $130 \mathrm{~m}, 52^{\circ} 6^{\prime} \mathrm{S}$, 694 'W, 3 enero 2004, Domínguez 128, 198 (CONC); Ultima Esperanza, cerro El Castillo, 150 m, 51 $1^{\circ} 17^{\prime} \mathrm{S}, 72^{\circ} 20^{\prime} \mathrm{W}, 1$ abril 1956, Magens, O. \& O. Matthei 3627 (CONC); Estancia Laguna Blanca, 150 m, 52 $2^{\circ} 13^{\prime} \mathrm{S}, 72^{\circ} 10^{\prime} \mathrm{W}, 5$ enero 1959, Magens, O. 3708, 3704 (CONC); Estancia Guido, 700 m, 
5054'S, 72²8’W, 1 enero 1952, Pfister \& Ricardi s.n. (CONC 12128); XII Región: Río Verde, a 150 km del estrecho, diciembre 1926, Guiñazú 59 (SI).

\section{Festuca pampeana Speg.}

ARGENTINA. Buenos Aires: Partido Coronel Suarez, Sierra de Cura Malal, Quebradas al sw, 4 noviembre 1939, Cabrera A. L. 28141(a) (SI); Sierra de Cura Malal, 28 noviembre 1963, Fabris H. A. \& H. Schwabe 5321 (LP); cerro de Cura Malal, 16 diciembre 1899, Spegazzini C. 1878 (SI); en la ladera NE, 17 noviembre 1982, Villamil C. B. 4724 (SI); cerro de Cura Malal, Spegazzini C. s.n. No. 140 Herb. Fac. Agro. Chacaritas (SI). Partido Torquist, cerro de la Ventana, 7 noviembre 1970, Burkart A. et. al. SI 26033 (b) (SI); Sierra de la Ventana, 10 noviembre 1907, Hicken C. M. 2100 (SI); Cerro de la Ventana, 9 noviembre 1938, Cabrera A. L. 2498 (SI, LP); Sierra de la Ventana, 7 octubre 1971, Cabrera A. L. 2556 (SI); Sierra de la Ventana, cerro Chaco, 13 noviembre 1943, Cabrera A. L. 28141(b) (SI); Sierra de la Ventana, 11 noviembre 1907, Hicken C. M. 5514 (SI); Sierra de la Ventana, al pie del cerro Ventana, 9 noviembre 1982, Villamil C. B. 4852 (SI); ea. cerro del Potrero 35, 18 noviembre 1981, Villamil C. \& E. G. Nicora 2540 (SI); Ruta provincial 76, 16 diciembre 1985, Molina A. M. 8095 (LP).

\section{Festuca panda Swallen}

CHILE. IV Región: Provincia Limarí, Quebrada Larga, 3400 m, 3044’S, 70²3`W, 17 febrero 1958, Jiles C. 3382c* (CONC).

\section{Festuca parodiana (St.-Yves ex Parodi) Nicora}

ARGENTINA. Jujuy Departamento Capital, La Almona, 25 enero 1976, Cabrera A. L. et al. 27593 (SI); Dr. M. Belgrano, Lagunas de Yala, 2400 m, 22 febrero 1997, Zuloaga F. O. et al. 6147 (SI); Tiraxi, 25 marzo 1993, Deginani N. \& A. M. Cialdella 199 (SI). San Juan: Departamento Barreal, Barreal, 14 febrero 1979, Ambrosetti et al. 662 (SI).

\section{Festuca parodii St.-Yves.}

Se conoce solamente de matrial tipo: ARGENTINA. Catamarca: Sin departamento, "Poman", diciembre 1909, L. R. Parodi 2342 (lectotipo BAA 00000175!; isolectotipo LIL 505358!).

29. Festuca purpurascens Banks \& Solaner. ex Hook. f.

ARGENTINA. Chubut: Departamento Futaleufú, Región del río Corcovado, $641 \mathrm{~m}, 43^{\circ} 32^{\prime} \mathrm{S}$, 71³6'W, no date, Illín, N. 40 (SI); Parque Nacional Los Alerces, Lago Menéndez, El Café, 10 febrero 1949, Soriano, A. 3449 (BAA). Neuquén: Departamento Huiliches, Parque Nacional Lanín, Lago 
Tromen, 1049 m, 39³4'11,6"S, 71² 26'26,7"W, 2 febrero 2003, Peterson, P. M. et al. 17382, 17401 * (SI); Los Lagos, Parque Nacional Los Arrayanes, Peninsula Quetrihué, lado norte, sendero Los Chañares, cerca del Villa La Angostura, 1180 m, 4047'3"S, 71³9'49"W, 5 diciembre 2008, Morrone, O. et al. 6110 * (SI). Río Negro: Departamento Bariloche, Parque Nahuel Huapi, valle del Río Alerce, Boelcke, O. \& M. N. Correa 5605, 5620 (SI). Santa Cruz: Departamento Lago Argentino, 66 km W of Calafate and $8 \mathrm{~km}$ E of Perito Moreno Glacier, $257 \mathrm{~m}, 55^{\circ} 28^{\prime} 42,5 " \mathrm{~S}, 72^{\circ} 58^{\prime} 47^{\prime \prime} \mathrm{W}, 19$ enero 2003, Peterson, P. M. et al. 17147 (SI). Tierra del Fuego e Islas del Atlántico Sur: Departamento Ushuaia, Harberton Park, 15 febrero 1966, Goodall, R. N. 327 (LP).

CHILE. IX Región: Provincia Cautín, Arauco, 5 agosto 1951, Barros, E. 10170 (BAA); Cautín, Chiloé, febrero 1991, Dubcovsky 803 (BAB); Temuco, Cerro Ñielol, 5 agosto 1934, Montero, O. 2028 (BAA). X Región: Provincia Osorno, Puerto Octavy, centinela, 21 enero 1943, Ponce, A. 63 * (SGO); Puerto Varas Gallardo-Ensenada, camino al Río Blanco, 31 enero 1943, Ponce, A. 80 (SGO). XI Región: Provincia Aisén, entre el glacial y la morrena más extendida de los últimos siglos, al este del hotel, 4 m, 14 enero 1959, Muñoz, C. 6152 (SGO); Laguna de San Rafael en los lavados del glacial, 12 enero 1959, Muñoz, C. 6065, 6071 (SGO); Istmo de Foqui, 1 febrero 1921, colector desconocido s. $n$. (SI 15242, SI 10995); Laguna San Rafael, Puntilla del Cisne, 14 enero 1978, Villaseñor, R. 819 (SGO); Provincia General Carrera, Rada de Quesahuén, 50 m, 46 $22^{\circ}{ }^{\prime} \mathrm{S}, 73^{\circ} 44^{\prime} \mathrm{W}, 4$ febrero 1959, Schlegel, F. 2058 (CONC); XII Región: Provincia Magallanes Laguna Blanca, febrero 1927, Guiñazú 174 (BAA), Isla Grevy, Archipielago Cabo de Hornos, punta Dillon, paso norte, 18 enero 1982,

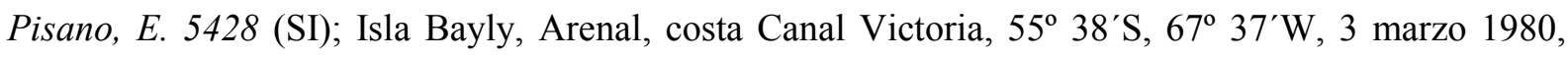
Pisano, E. 5164 (SI); Caleta Awaiakirrh, Isla Hoste, 27 enero 1982, Pisano, E. 5548 (SI); Río Pingo, 17 febrero 1988, Rúgulo, Z. 46 (SI); Provincia Última Esperanza, comuna de Puerto Natales, Estero Falcon, 0 m, 4944'57,49"S, 73 54'32,77"W, 19 enero 2010, Domínguez, E. 1191 a (CONC); Parque Nacional Torres del Paine, Lago Pehoe, 15 noviembre 1988, Rúgolo, Z. 1145, 1159, 1173 (SI); Seno

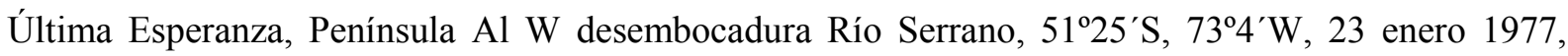
T.B.P.A. 1906 (SI); Seno Última Esperanza, Puerto Bella Vista, N shore bay NE of old camp, 51 $28^{\prime} \mathrm{S}$,

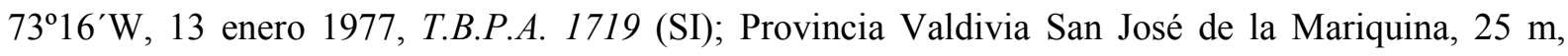
39² $31^{\prime} \mathrm{S}, 72^{\circ} 58^{\prime} \mathrm{W}, 8$ julio 1930, Aravena 308 (CON); Valdivia, enero 1901, Buchtien, O. 2922 (BAA); Cordillera Pelada, 800 m, 3 enero 1932, Gunckel 3032 (BAA); Valdivia, 16 diciembre 1933, Gunckel 7352 (BAA); Corral, 27 June 1930, Gunckel 1823 (BAA, CONC); Corral, 27 June 1931, Gunckel 7188 (BAA); Gualli Huapi, 560 m, 24 julio 1947, Gunckel 17032 (CONC).

\section{Festuca pyrogea Speg.}

ARGENTINA. Chubut: Departamento Tehuelches, La Blache, Teka, 9 diciembre 1946, Nicora, E. G. 9282 (SI); Lago Los Niños, orillas, 7 km se lago Vintter, 30 enero 1988, Nicora, E. G. 9558 (SI); Lago Los Niños, suelos arenosos en claros del bosque, 20 enero 1992, Nicora, E. G. 9614 (SI); Languiñeo, Lago el Guacho, orillas, suelos húmedos, 4 febrero 1989, Soriano, A. 3090 (SI); Futaleufú, región del 
Río Corcovado, no date, Illín, N. 186 (SI); Paso de Indios, valle de Laguna Blanca, $71^{\circ} 15^{\prime} \mathrm{S}, 45^{\circ} 52^{\prime} \mathrm{W}$, 12 diciembre 1901, Koslowsky 153 (SI); Lago Vintter, alrededores de la cabaña, suelo arenoso, 29 enero 1997, Soriano, A. 3078 (SI); km 8 of Río Pico on road towards Lago Vintter, 815 m, 448'33"S, $71^{\circ} 2641^{\prime \prime W}, 26$ enero 2003, Peterson, P. M. et al. 17292 (SI). Neuquén: Departamento Minas, Sierra de Cochicó, 36²1'S, 70³4'W, 29 enero 1970, Boelcke, O. et al. 14086 (SI); Picunches, Paseo Pino Hachado, 1885-1935 m, 38³9'45,7"S, 7053 47,3"W, 4 febrero 2003, Peterson, P. M. et al. 17459 (SI). Río Negro: Departamento Valcheta, Cerro Corona, 6 enero 2003, Troiani, H. \& P. Steibel 15574, 15602 (SI). Santa Cruz: Departamento Güer Aike, Estancia Stag River, meseta Latorre, Cerro Punta Gruesa, 970 m, 51 32 'S, 755' W, 24 enero 1978, Méndez, E. 1054 (SI); Loma Rospentek, 320 m,

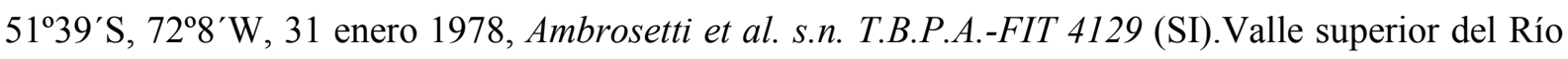
Turbio, faldeo Cordillera Chica, $700 \mathrm{~m}, 51^{\circ} 27^{\prime} \mathrm{S}, 72^{\circ} 6^{\prime} \mathrm{W}, 5$ febrero 1978, Ambrosetti et al. s.n. T.BP.A.-FIT 3639 (SI); $116 \mathrm{~km}$ SE of Turbio along hwy 40 towards Río Gallegos, 197 m, 51 54'58"S, $70^{\circ} 46$ 29"W, 17 enero 2003, Peterson, P. M. et al. 17099 (SI); Estancia La Carlota, sección San Elías 51 $23^{\prime} \mathrm{S}, 71^{\circ} 24^{\prime} \mathrm{W}, 18$ enero 1978, Roig, F. et al. s.n. T.B.P.A.-FIT 2711 (SI); Estancia Stag River, Meseta La Torre, Cerro Punta Gruesa, 51 $32^{\prime} \mathrm{S}, 7^{\circ}{ }^{\prime} \mathrm{W}, 25$ enero 1978, Roig, F. et al. s.n. T.B.P.A.FIT 2900, 2996, 2951, 2996, 3062 (SI); Estancia Stag River, meseta Latorre, co. Punta Gruesa, 1050 m, 51 ${ }^{\circ} 32^{\prime} \mathrm{S}, 7^{\circ} 5^{\prime} \mathrm{W}, 24$ enero 1978, Roig, F. et al. s.n. T.B.P.A.-FIT 3012, 3010 (SI); Estancia La

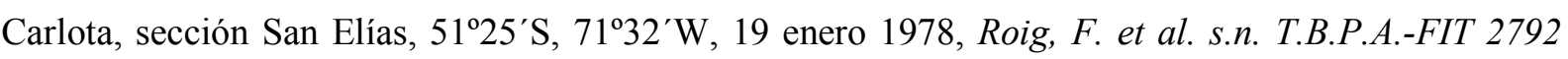
(SI); Lago Argentino, Lago San Martín, Estancia La Federica, 390 m, 48 $58^{\prime} \mathrm{S}, 72^{\circ} 11^{\prime} \mathrm{W}, 23$ enero 1967, Roig, F. et al. s.n .T.B.P.A.-FIT 2986 (SI); Lago Buenos Aires, $35 \mathrm{~km}$ al N de Perito Moreno, 46 $17^{\circ} \mathrm{S}, 7^{\circ} 44^{\prime} \mathrm{W}, 30$ enero 1967, Boelcke, O. et al. 12957 (SI); Río Chico, $41 \mathrm{~km}$ al W de Bajo

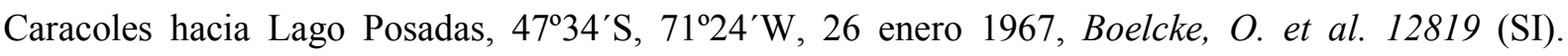

Tierra del Fuego e Islas del Atlántico Sur: Departamento Río Grande, Estancia Cullen, 2 km SE of settlement, 20 m, 52 $54^{\prime} \mathrm{S}, 68^{\circ} 25^{\prime} \mathrm{W}, 13$ enero 1968, Moore, D. M. 1451 (SI).

CHILE. XII Región: Provincia Ultima Esperanza, Puerto Toro, Ventisquero Balmaceda, Morrena Frontal, 51 $25^{\prime} \mathrm{S}, 7^{\circ} 8^{\prime} \mathrm{W}, 20$ enero 1977, Moore, D. M. s.n. T.B.P.A. 1849 (SI); Sierra de Los

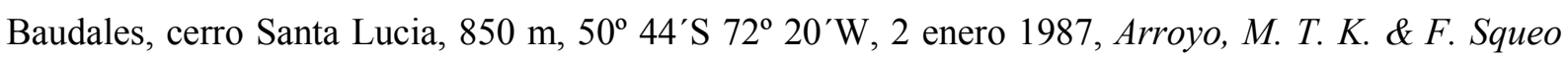

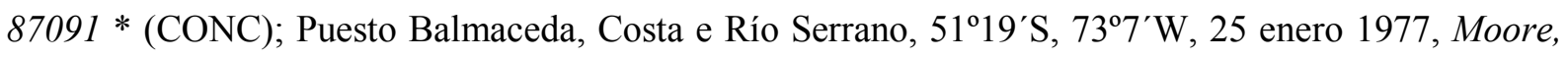
D. M. s.n. T.B.P.A. $1952^{*}$ (SI); Sección Lazo, Cerro Toro, 51¹0' $\mathrm{S}, 72^{\circ} 45^{\prime} \mathrm{W}, 11$ diciembre 1973, Pisano, E. $4127 *$ (CONC).

\section{Festuca rigescens (J. Presl) Kunth}

ARGENTINA. Catamarca: Deptartamento Antofagasta de la Sierra, Los Nacimientos, en las vegas, 19-II-1974, Botta et al. 690* (SI); Tinogasta, Pampa de Pedro, 4010 m s.m., 27-II-1950, Hunziker et al. 4119 (BAA). La Rioja. Deptartamento Vinchina, Sarmiento, Pucha-Pucha, 3600 m s.m., 28-I1949, Krapovickas et al. 5673 (SI). San Juan. Deptartamento Iglesia, Parque Nacional San Guillermo, Agua del Godo, orillas del río San Guillermo, 19-II-1981, Nicora et al. 8196 (SI); Parque Nacional 
San Guillermo, vega de Los Leones, 18-I-1983, Nicora et al. 8593*(SI); 14-I-2000, Haene et al. 2111 (SI). Sin provincia consignada. Sin datos, Parodi 10085, (BAA). Sin datos, Trier 9824 (SI).

CHILE. II Región: Provincia Antofagasta, vega en el salar de Aguas Calientes, 3680 m, 2458'S, 68³ 'W, febrero 1997, Arancio, G. \& F. Squeo 10473 (CONC); Provincia El Loa, Aguada Linzor, faldeos pedregosos, $4300 \mathrm{~m}, 2^{\circ} 13^{\prime} \mathrm{S}, 68^{\circ} 3^{\prime} \mathrm{W}, 15$ enero 1981, Villagrán, C. 2982-B, 3014-B* (CONC). IV Región: Provincia Elqui, Coquimbo, Baños del Toro, 3300 m, 19 febrero 1936, Cabrera, A. L. 3556 * (LP). XV Región: Provincia Arica, Las Cuevas, 4400 m, 22 febrero 1978, Escobar, A. H. $X-235^{*}$ (CONC, SI); Termas Chirigualla, SW of Chungará, 4800 m, 18²0’35,4"S, 69¹0’30,2"W, 5 abril 2001, Peterson, P. M. et al. 15763 * (CONC, SI); Provincia Parinacota, Cerro Guane-Guane, $4500 \mathrm{~m}, 18^{\circ} 10^{\prime} \mathrm{S}, 69^{\circ} 15^{\prime} \mathrm{W}, 20$ abril 1980, Kalin, M. et al. $2661 * 2703 *$ (CONC); Camino de Portezuelo de Champiquiña a Putre km 18, $4250 \mathrm{~m}, 18^{\circ} 15^{\prime} \mathrm{S}, 69^{\circ} 35^{\prime} \mathrm{W}, 11$ febrero 1964, Marticorena et al. 114, 134*, $194 *(\mathrm{CONC}) ; 22 \mathrm{~km}$ E of Zapahuira at Portezuelo Cahpiquiña, $4460 \mathrm{~m}$, 18¹9'30"S, 69³0'13"W, 2 abril 2001, Peterson, P. M. et al. 15733 (CONC, SI); 106 km NE of Huara on road towards Colchane, 4340 m, 19³4'53,2"S, 68 58'1"W, 26 marzo 2001, Peterson, P. M. et al. 15649 (CONC); Cord. Volcan Tacora, Ancara, $4300 \mathrm{~m}, 17^{\circ} 44^{\prime} \mathrm{S}, 6^{\circ} 43^{\prime} \mathrm{W}$, abril 1926, Werdermann, E. 1127 (CONC, SI).

32. Festuca roigii Dubcovsky \& Rúgolo

ARGENTINA. Mendoza. Departamento Luján de Cuyo, Potrerillos, en médanos, 1920 m, 12 noviembre 1987, Méndez E. 5466 (SI); Potrerillos, frente a El Salto, en ladera Sw en la comunidad, protegida, 2450 m, 16 diciembre 1987, Méndez E. 5495 (SI); Puerto Mariños Potrerillos, al w frecuente en ladeas de umbríos, 1700 m, 28 octubre 1983, Méndez E. 3672 (SI).

\section{Festuca rubra L.}

ARGENTINA. Mendoza: Departamento Malargüe, Complejo Las Leñas, 2260 m, 9 enero 2012, Sede, S. M. \& S. Denham 380 (SI). Neuquén: Departamento Los Lagos, Fortín Chacabuco, 5 diciembre 1963, Vallerini, J. 401 (SI).

CHILE. IV Región: Provincia Elqui, canchas de sky, 3300 m, 29 51' S, 70³ 3’W, 24 febrero 1988, Squeo, F. 88171 (CONC). V Región: Provincia Los Andes, entre laguna Las Truchas y laguna Turqueza, 3200 m, 5 enero 1991, Arroyo, M. T. K. et al. 157 (CONC). XII Región: Provincia Magallanes, Punta Arenas, 53 0’S, 7054'W, 26 enero 1955, Magens 3096* (CONC); Magallanes, enero 1917, Bonarelli, A. 110 (SI); Provincia Última Esperanza, Salto Grande del Paine, 24 diciembre 1969, Pisano, E. 2365 (CONC).

\section{Festuca Subantártica Parodi}


ARGEnTINA. Tierra del Fuego e Islas del Atlántico Sur: Departamento Ushuaia, Caleta Awaiakirrh, $52^{\circ} 9^{\prime} \mathrm{S}, 73^{\circ} 21^{\prime} \mathrm{W}, 28$ enero 1982, Pisano, E. 5444, $5561^{*}(\mathrm{SI})$.

CHILE. XII Región: Provincia Magallanes, Seno Unión, N side, Ancón sin salida, 95 m, 514ㄴ'S, 74¹'W, 10 enero 1976, Boelcke, O. et al. s.n. T.B.P.A. 866 (SI); Isla Piazzi, caleta Ocasión, Abra Leackey's Retreat, 1 m, 51 ${ }^{\circ} 44^{\prime} \mathrm{S}, 7^{\circ} 1^{\prime} \mathrm{W}, 14$ enero 1976, Dollenz, O. et al. s.n. T.B.P.A. 1048 (SI);

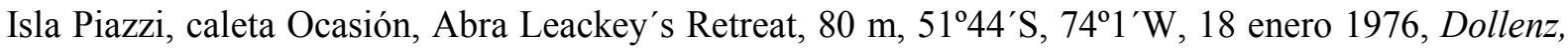
O. et al. s.n. T.B.P.A. 1060, 1076 (SI); Isla Rennel Norte, Canal Smyth, $51^{\circ} 44^{\prime} \mathrm{S}, 74^{\circ} 1^{\prime} \mathrm{W}, 24$ enero 1976, Dollenz, O. et al. s.n. T.B.P.A. 1168 * (SI); Isla Piazzi, caleta Ocasión, Abra Leackey's Retreat, $150 \mathrm{~m}, 51^{\circ} 31^{\prime} \mathrm{S}, 7^{\circ} 16^{\prime} \mathrm{W}, 16$ enero 1976, Dollenz, O. et al. s.n. T.B.P.A. 1027 (SI); Seno Ultima Esperanza, Puerto Bella Vista S Shore, $100 \mathrm{~m}, 55^{\circ} 38^{\prime} \mathrm{S}, 67^{\circ} 35^{\prime} \mathrm{W} 11$ enero 1977, Moore, D. et al. s.n. T.B.P.A. 1596 (SI); Fiordo Contralmirante Martínez Brazo S-E, 54³3'S, 70³6'W, 20 marzo 1997, Henríquez, H. et al. 97 * (CONC); Fiordo Nevado, Isla Santa Ines, Bahía Havergal, 5331'S, 7246,6’W, 29 febrero 1990, Henríquez, H. et al. 10, 28 (CONC); Bahía Campaña, Isla Clarence, 54'5'S, 71²'W, 27 febrero 1975, Pisano, E. 4431*(CONC); Costa Canal Washington, 11 enero 1980, Pisano, E. 5102 (SI); Isla Grevy, Archipiélago Cabo de Hornos Rada Norte, Bahía Gretton, 17 enero 1982, Pisano, E. 5387, 5421 (SI); Fiorodo Silva Palma, Angostura Titus, costa opuesta al aserradero, 8

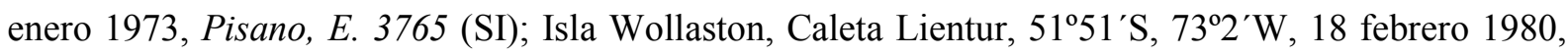
Pisano, E. 5026 (SI); Puerto Bella Vista, Parque Nacional Monte Balmaceda, 51 ${ }^{\circ} 27^{\prime} \mathrm{S}, 73^{\circ} 15^{\prime} \mathrm{W}, 17$ enero 1996, Pisano, E. et al. 8581 (CONC); Península Roca, seno Resi, 175 m, 22 febrero 1978, Pisano, E. s.n. T.B.P.A. 2838 * (SI).

\section{Festuca superba Parodi ex Türpe}

ARGENTINA. Jujuy: Departamento Capital, Termas del Reyes, 7 enero 1968, Cabrera A. L. 18879 * (SI); quebrada de Yala, 19 enero 1976, Cabrera A. L. et al. 27380 (SI); al pie de la cuesta de Yala., 29 marzo 1992, Cabrera A. L. et al. 34886 (SI); Lagunas de Yala, 16 noviembre 1987, Nicora E. 8740 (SI); Laguna de Yala, subida a las Lagunas, 16 enero 1988, Zuloaga F. O. y Deginani N. B. 3545 (SI); subida a lagunas de Yala, 30 enero 1975, Zuloaga F. O. y Deginani N. B. 383 (2 láminas) (SI).

\section{Festuca ulochaeta Nees ex Steud.}

ARGENTINA. Misiones: Departamento Candelaria, Matires, 9 octubre 1947, Bertoni 3398 (LIL); Bernardo de Irigoyen, 22 febrero 1971, Burkart A. 28250 (SI); Gral. Manuel Belgrano, Salto

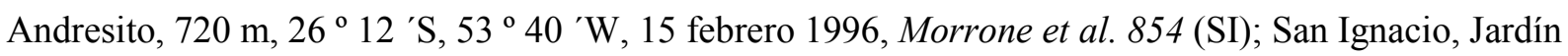
de América, Salto el Tabay, 10 octubre 200, Zuloaga F. O. \& O. Morrone 787 (SI); San Pedro, Arroyo Biguá, cerca del pueblo, aguas abajo del tajamar, $510 \mathrm{~m}, 26^{\circ} 37^{\prime} \mathrm{S}, 54^{\circ} 5$ 'W, 13 marzo 2002, Múlgura M. E. et al. 3208 *(SI); Cainguás, Salto Colondrina (sobre Arroyo Guiray), 390 m, $27^{\circ} 5$ 'S, $54^{\circ} 29$ 'W, 8 noviembre 2000, Múlgura M. E. et al. 2443 (SI). Jujuy: Departamento Dr. Manuel

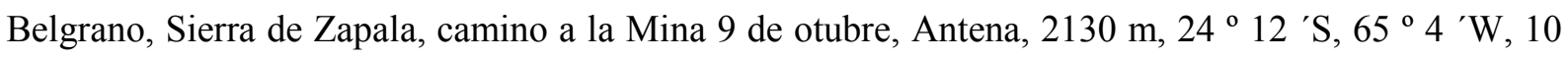


noviembre 2002, Zuloaga F. O. et al. 7620 (SI); Santa Barbara, sierra del Centinela, por el camino maerero que parte de El fuerte, 1600 m, 3 junio 1973, Türpe A. M. 2746 (LIL). Salta: Departamento Santa Victoria, camino entre Toldos y Lipeo, 1650 m, 11 noviembre 1974, Türpe A. M. 2930, 2932 (LIL). Tucumán: Departamento Tafí, Cumbre de Tafí, 8 febrero 1962, Meyen T. et al. 2113 (LIL).

BRASIL. Paraná: Región de Tres Barras, locis graminosis, 27 enero 1916, Dusén P. 17561 (SI). Río Grade do Sul: Región de Sao Leopold, sine data, 1000 m, sine data, Dutra J. 331 (SI). Santa Catarina: Región de San Juaquín, morro de Igreja, 1800 m, 21 enero 1960, Mattos J. 7453-a [8467-a] (SI); Región de Campo Ere, sine data, 29 febrero 1964, Eskuche U. 1641-41 (LIL); sin región, en bosque de Araucaria angustifolia, 1300 m, 25 enero 1971, Castellanos A. 24729 (SI); sin estado, sin región, L. Ar. De paula, Vila Olivia, 24 febrero 1946, Rambo B. 31319 (LIL).

\section{Festuca uninodis Hack.}

ARGENTINA. Catamarca: Departamento Belén, "El Potrero", Laguna Blanca, 3500 m, 25 marzo 1934, Peirano 305 (LIL). Jujuy: Departamento Humahuaca, $10 \mathrm{~km}$ de cianzo camino a Santa Ana, Abra de Zenta, ruta provincial 73, $4500 \mathrm{~m}, 23^{\circ} 10^{\prime} \mathrm{S}, 65^{\circ} 2$ 'W, 12 febrero 1998, Morrone O. et al. 2502 (SI); entre palca de Aparzo y St. Ana, Abra de Zenta., 4400 m, $23^{\circ} 10^{\prime} 13$ "S, $65^{\circ} 2^{\prime} 60$ "W, 11 febrero 2007, Zuloaga F.O. et al. 9192 (SI). Salta: Departamento Santa Victoria, Ruta provincial 7, km 12., 4290 m, 13 febrero 1995, Deginani N. et al.796 (SI); Abra de Lizoite., 4590 m, 22 ${ }^{\circ} 13^{\prime} 8^{\prime \prime} \mathrm{S}$, 65²13', 33"W, 8 marzo 2002, Negritto, M. A. 409a (SI); desconocido, La Laguna, 25 enero 1914, Rodríguez F. M. 1330 (BAB, LIL, SI). Tucumán: Departamento Tafí, Cerro Negrito-Cumbres Calchaquies., 4500 m, 17 febrero 1990, Ayarde H. 346 (LIL); Cumbres Calchaquís, próximo a las lagunas., 4300 m, 27 julio 1913, Castillón L. 3209 (LIL); C. Calchaquíes, callejones., 4200 m, 1 marzo 1971, Castillón L. 2858 (LIL); Cumbres Calchaquís, 4200 m, 4 febrero 1907, Lillo, M. 5615 (LIL); Cumbres Calchaquíes, lagunas, 4600 m, 3 febrero 1903, sin colector 3067 LIL 44223 (LIL).

\section{Festuca ventanicola Speg.}

ARGENTINA. Buenos Aires: Departamento Tornquist, Partido Tornquist, Sierra de la Ventana, cerro de la ventana, 9 noviembre 1988, Cabrera A. L. 4738 (SI); Sierra de la Ventana, 11 noviembre 1907, Hicken C. M. s.n. SI 18464 (SI); Sierra de la Ventana, cerro de la ventana, 4 noviembre 1941, Cabrera A. L. 7327 (SI); Partido Saavedra, Sierra Cura Malal, 12 diciembre 1899, Spegazzini C. 1880 (SI); Sierra de la Ventana, cerro de la ventana, 18 noviembre 1887, Lucas Peralta S. R. 147 (SI).

\section{Festuca weberbaueri Pilg.}

ARGENTINA. Jujuy: Departamento Caspalá, cerros, 1 marzo 1940, A. Burkart y N. Troncoso 11909 (LIL); Tumbaya, San Antonio (abra) de los Pibes, 3850 m, 5 enero 1953, H. Sleumer 3239 (LIL); Valle Grande, serranías de Calilegua, cerro Hermoso, 17 febrero 1965, 2800 m, Fabris y Crisci 5897 (SI); sin departamento, estación Volcán, febrero 1920, L. Castillon 7096, 9285, 368 (LIL). La Rioja: 
Departamento Chilecito, La Mesada, Sierra de Famatina, 14 enero 1947, J. H. Hunziker 1904 (SI).

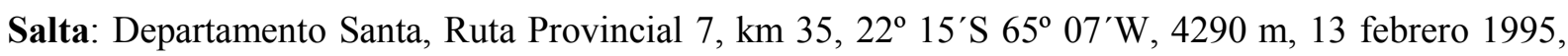
Deginani et al. 790 (SI).

\section{Festuca werdermannii St.-Yves}

ARGENTINA. San Juan: Departamento Iglesia, Río Las Taguas, Parcela 1, Arroyo Las Yaretas, 6 enero 2000, Gajardo s.n. 7 * (SI); Confluencia del Río Turbio y Río Las Taguas, 20 marzo 1998 Kiesling, R. 9056 (SI); Río Turbio, 29²2'17"S, 6955'86"W, 23 enero 1995, Kiesling, R. et al. 8677 (SI); Río Las Taguas, Quebrada del Río Turbio, camino al ex campamento de Mina Aguilar, 29²0'28"S, 6957'29"W, 21 enero 1999, Kiesling, R. et al. 9223, 9226 (SI); N de Gendarmería, Río Blanco, 3750 m, 22 febrero 1995, Kiesling, R. et al. 8664 (SI); Zona del Río de Las Taguas, Quebrada Potrerillos, 3700 m, 29 $21^{\prime} \mathrm{S}, 6^{\circ} 56^{\prime} \mathrm{W}, 4$ febrero 2000, Ruthsatz, B. $9164 *$ (SI). La Rioja: Departamento Chilecito, Sierra de Famatina, Río Amarillo, encrucijada, 3400 m, 4 febrero 1995, Teillier, S. y C. Márquez 4526 * (SI).

CHILE. III Región: Departamento Huasco, cuenca de El Transito, quebrada Mina Fortuna, 3800 m, $28^{\circ} 37^{\prime} \mathrm{S}, 69^{\circ} 53^{\prime} \mathrm{W}$, febrero 2002, Teillier, S. 4984, 5056 (CONC); Quebrada Cantarito, entre quebrada

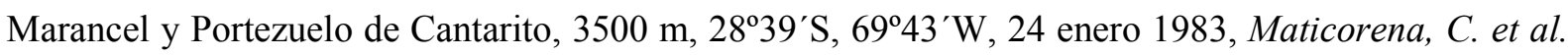
83505 (CONC). IV Región: Provincia Elqui, Baños del Toro, Río Toro, 3300 m, 18 enero 1936, Cabrera, A. $3521^{*}$ (SI); Baños del Toro, en las vegas, 3500 m, 2950'S, 70²' W, enero 1979, Jiles, C. 6528 (CONC); Baños del Toro, 3400 m, 2950'S, 70²' W, enero 1966, Peña s.n. (CONC 71691); Cordillera Doña Ana, Quebrada del Toro Muerto, 3580 m, 29 $48^{\prime}$ S, 70 ${ }^{\circ} 3^{\prime} \mathrm{W}, 14$ enero 1992, Arancio, G. 92-032 (CONC).

41. Festuca yalaensis Joch. Müll. \& Catalán

Se conoce solamente de matrial tipo: ARGENTINA. Jujuy: Departamento Doctor Manuel Belgrano,

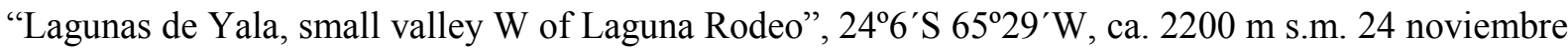
2008, J. Müller \& P. Catalán 10522 (holotipo JE; isotipos SI 96835!, SI 126080!).

\section{Otros taxones estudiados}

\section{Festuca asplundii E.B. Alexeev}

PERÚ. Cuzco: Urubamba, Ollantaytambo, Aba Malaga, on the slope $50 \mathrm{~m} \mathrm{SW}$ of the south facing

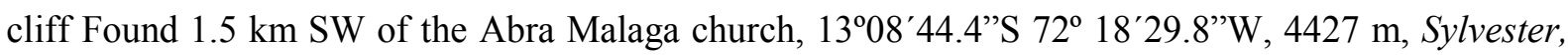
S. P. 1401 (CUZ, Z).

\section{Festuca casapaltensis Bell.}


PERÚ. Cuzco: Calca, Calca, the grassy grazed land found to the immediate E of the prominent tower

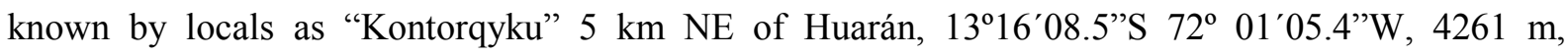
Sylvester, S. P. 1156(CUZ, Z).

\section{Festuca cochabambana E.B. Alexeev}

BOLIVIA. Cochabambana: Chapare, c $1 \mathrm{~km}$ beyond Corani Pampa (11 km off Cochabamba-Chapare highway), 2400 m, 9 diciembre 1995, Wood, J.R.I. 10217 (LPB).

\section{Festuca cuzcoensis Stancik \& Peterson}

PERÚ. Cuzco: Provincia La Convención, Quellouno, lacco, cabecera del río Timppia (santuario Nacional Megantoni), 3690 m, 21 abril 2008, Treviño, I. et al. 195 (HUSA).

\section{Festuca dolichophylla J. Presl}

BOLIVIA. La Paz: Provincia Aroma, south of La Paz on Hwy 1 towards Oruro, 6.7mi NW of Villa Loza on road to Urmiri and Sapahaqui, 4040 m, 4 marzo 1993, Peterson, P. M. et al. 12631 (LPB).

\section{Festuca chimborazensis E.B. Alexeev}

ECUADOR. Bolivar: $66.5 \mathrm{~km} \mathrm{SW}$ of Ambato on Highway to Guarando and $2.2 \mathrm{~km}$ on road to Facundo Vela, 4300 m, 3 mayo 1990, Peterson, P. M. et la. 8995 (QCNE).

7. Festuca vaginalis (Benth.) Lægaard

ECUADOR. Pichincha: Páramo de Guamani, app. $5 \mathrm{~km} \mathrm{~W}$ of Paso de la Virgen, Polylepis forest, partly burned, $78^{\circ} 14^{\prime} \mathrm{W} 0^{\circ} 18^{\prime} \mathrm{S}, 3750$ m, 8 febrero 1984, Lagaard, S. 51386 (QCNE). 


\section{APÉNDICE II. REFERENCIAS BIBLIOGRÁFICAS}

Abernethy, G. A., Fountain, D. W. \& McManus, M. T. 1998. Observations on the leaf anatomy of Festuca novae-zelandiae and biochemical responses to a water deficit. New Zealand Journal of Botany 36: 113-123.

Ainscough, M. M., Barker, C. M. \& Stace. C. A. 1986. Natural hybrids between Festuca and species of Vulpia section Vulpia. Watsonia 16: 143-151.

Aiken, S. G. \& Lefkovitch, L. P. 1984. The taxonomic value of using epidermal characteristics in the Canadian rough fescue complex (Festuca altaica, F. campestris, F. hallii "F. scabrella"). Canadian Journal of Botany 62: 1864-1870.

Aiken, S.G., Darbyshire, S.J. \& Lefkovitch, L.P. 1985. Restricted taxonomic value of leaf sections in Canadian narrow-leaved Festuca (Poaceae). Canadian Journal of Botany 63 (6): 995-1007.

Aiken, S.G. \& Darbyshire, S.J. 1990. Fescue grasses of Canada. Agriculture Canada Research Branch, publication 1844/E.

Aiken, S. G. \& Consaul, L. L. 1995. Leaf cross sections and phytogeography: a potent combination for identifying members of Festuca subgg. Festuca and Leucopoa (Poaceae) occurring in North America. American Journal of Botany 82: 1287-1299.

Aiken, S.G., L.L. Consaul, \& Lefkovitch, L.P. 1995. Festuca edlundiae (Poaceae), a high arctic, new species compared enzymatically and morphologically with similar Festuca species. Systematic Botany 20:374-392.

Aiken, S.G., M.J. Dallwitz, C.L. McJannet \& Consaul, L.L. 1997. Biodiversity among Festuca (Poaceae) in North America: Diagnostic evidence from DELTA and clustering programs, and an INTKEY package for interactive, illustrated identification and information retrieval. Canadian Journal of Botany 75:1572-1555.

Alexeev, E.B. 1977. To the systematics of Asian fescues (Festuca). I. Subgenera Drymanthele, Subulatae, Schedonorus, Leucopoa). Botaničeskii Žhurnal (Moscow \& Leningrad) 82 (3): 95102.

Alexeev, E.B. 1978. To the systematics of Asian fescues (Festuca). 2. Subgenus Festuca. Botaničeskii Žhurnal (Moscow \& Leningrad) 83 (4): 109-122.

Alexeev, E.B. 1980. Festuca L. Subgenera et sectiones novae ex America boreali et Mexica. Novosti Sistematiki Nizshikh Rastenii 17: 42-53. 
Alexeev, E.B. 1982. New and little known Festuca of North America. Byulleten' Moskovskogo Obshchestva Ispytatelei Prirody. Otdel biologicheskii 89: 111-117.

Alexeev, E.B. 1984. The new taxa of the genus Festuca (Poaceae) from Colombia and Ecuador. Botaničeskii Žhurnal (Moscow \& Leningrad) 69: 1543- 1551.

Alexeev, E.B. 1986. Festuca L. (Poaceae) in Venezuela, Colombia \& Ecuador. Novosti Sistematiki Vysshikh Rastenii 23: 5-23.

Balzarini, M.G., Gonzalez L., Tablada M., Casanoves F., Di Rienzo J.A. \& Robledo, C.W. 2008. Infostat. Manual del Usuario. Editorial Brujas, Córdoba. 336 pp.

Bailey, J. P. \& Stace, C.A. 1984. Chromosome number reports LXXXIII. In A. Love (Ed.), Taxon $33: 351-54$.

Bardoux, S. 1971. Sur l'anatomie de la feuille de Festuca arundinacea Schreb., Festuca pratensis Huds., Lolium multiflorum Lam. et leurs hybrides. Bulletin de la Société Vaudoise des Sciences Naturelles 71: 15-22.

Barker, C.M. \& Stace, C.A. 1982. Hybridization in the genera Vulpia and Festuca: the production of artificial $\mathrm{F}_{1}$ plants. Nordic Journal of Botany 2: 435-444.

Barthlott W, Neinhuis C, Cutler D, Ditsch F, Meusel I, Theisen I. \& Wilhelmi, H. 1998. Classification and terminology of plant epicuticular waxes. Botanical Journal of the Linnean Society 126: 237-60.

Borchsenius F. 2009. FastGap 1.2. Department of Biosciences, Aarhus University, Denmark. Published online at http://www.aubot.dk/FastGap_home.htm

Borrill, M., Tyler, B. F. \& Lloyd-Jones, M. 1971. Studies in Festuca. 1. A chromosome atlas of Bovinae and Scariosae. Cytologia 36: 1-17.

Briceño, B. \& Morillo, G. 1994. El género Festuca L. (Poaceae) en los páramos de Mérida. Ernstia 4: 73-88.

Brown, W.V. 1975. Variations in anatomy, associations, and origins of Kranz tissue. American Journal of Botany 62: 395-402. Doi:10.2307/2442093

Cabrera, A.L \& Willink A. 1973. Biogeografia de América Latina. Monografia 13. Serie de Biología. Secretaría General de la Organización de los Estados Americanos. Washington DC. EEUU. $120 \mathrm{pp}$. 
Cabrera, A.L. 1957. La vegetación de la Puna Argentina. Revista de Investigaciones Agrícolas 11(4): $317-412$

Cain, A. J. 1954. Animal species and their evolution. Hutchinson. Londres. 250 pp.

Camus, A. 1946. Le genere Pseudobromus Schum. a Madagascar. Notulae Systematicae 12: 149-151.

Catalán, P., Kellogg, E.A., \& Olmstead, R.G. 1997. Phylogeny of Poaceae subfamily Pooideae based on chloroplast $n d h$ F gene sequences. Molecular Phylogenetics and Evolution 8 (2): 150-166.

Catalán, P., Torrecilla, P., López Rodríguez, J.A. \& Olmstead, R.G. 2004. Phylogeny of the festucoid grasses of subtribe Loliinae and allies (Poeae, Pooideae) inferred from ITS and trnL-F sequences. Molecular Phylogenetics and Evolution 31(2): 517-541.

Catalán, P. 2006. Phylogeny and evolution of Festuca L. and related genera of subtribe Loliinae (Poeae, Poaceae). En A.K. Sharma \& A. Sharma (eds.). Plant Genome. Biodiversity and Evolution, part D, Vol. 1. Science Publishers, Enfield, NH, US, 255-303 pp.

Catalán, P., Torrecilla, P., López-Rodríguez, J.A., Müller, J. \& Stace, C.A. 2007. A systematic approach to subtribe Loliinae (Poaceae: Pooideae) based on phylogenetic evidence. Aliso: A Journal of Systematic and Evolutionary Botany 23: 380-405.

Catalán, P. \& Müller, J. 2012. Festuca. En A. M. Anton \& F. O. Zuloaga (eds). Flora de Argentina, Vol. 3, Tomo II. 219-250 pp. Gráficamente Ediciones, Córdoba, Argentina.

Clayton, W. D. 1970. Gramineae (Part 1). En E. Milne-Redhead \& R. M. Polhili (eds.), Fl. Trop. Africa: 1-176.

Clayton, W.D. \& Renvoize, S.A. 1986. Genera Graminum: Grasses of the World. Her Majesty's Stationery Office, London, 389 pp.

Charmet, G., Ravel, C. \& Balfourier, F. 1997. Phylogenetic analysis in the Festuca-Lolium using molecular markers and ITS rDNA. Theoretical and Applied Genetics 94: 1038-1046.

Connor, H.E. 1960. Variations in leaf anatomy in Festuca novae-zelandiae (Hack.) Cockayne and F. matthewsii (Hack.) Cheeseman. Journal of the Royal Society of New Zealand 3: 468-509.

Connor, H. E. 1998. Festuca (Poeae: Gramineae) in New Zealand. I. Indigenous Taxa. New Zealand Journal of Botany 36: 329-367

Cutler, D.F. 1987. Anatomía vegetal aplicada. Ed.Mosaico, Argentina. 
Davidse, G. 1994. Festuca L. En G. Davidse, M. Sousa Sánchez \& A.O. Chater (eds.) Flora Mesoamericana. Universidad Nacional Autónoma de México, México. 6: 223-227pp.

Dallwitz, M.J. 1980. A general system for coding taxonomic descriptions. Taxon 29: 41-46.

Dani, M. \& Kovács, J.A. 2014. Leaf anatomical structures in Central European populations of the broad-leaved Festucataxa. Acta Botanica Hungarica 56 (3-4): (in press).

Darbyshire, S.J., Warwick, S.I. 1992. Phylogeny of North American Festuca (Poaceae) and related genera using chloroplast DNA restriction site variation. Canadian Journal of Botany 70: $2415-2429$.

Darbyshire, S.J. (1993) Realignement of Festuca subgenus Schedonorus with the genus Lolium (Poaceae). Novon 3: 239-243. http://dx.doi.org/10.2307/3391460

Darbyshire, S.J., Soreng, R.J., Stančík, D. \& Koch, S.D. (2003) Festuca. In: Soreng, R.J., Peterson, P.M., Davidse, G., Judziewicz, E.J., Zuloaga, F.O., Filgueiras, T.S. \& O. Morrone (ed.) Catalogue of New World Grasses (Poaceae): IV. Subfamily Pooideae. Contributions from the United States National Herbarium 48: 312-369.

Darbyshire, S.J. 2007. Schedonorus In: Barkworth, M.E., Capels, K.M., Long, S., Anderton, L.K. \& Piep, M.B. (Eds.) Flora of North America 24. Available from: http://herbarium.usu.edu/webmanual (accessed 1 May 2015)

Di Rienzo, J.A., Casanoves, F., Balzarini, M.G., Gonzalez, L., Tablada, M. \& Robledo, C.W. 2011. InfoStat, versión 2011, Grupo InfoStat, FCA, Universidad Nacional de Córdoba, Argentina. URL http://www.infostat.com.ar

Denham, S. \& Aliscioni, S. 2010. Species delimitation in the Sporobolus aeneus complex (Zoysieae, Chloridoideae, Poaceae) using the phylogenetic species concept. Taxon 59(6): 1765-1782.

Desvaux, É. 1854. Fam. CXLVI. Gramineas. In: Gay, C.C. (Ed.) Flora Chilena 6. Fain \& Thunot, Paris, pp. 233-469.

Doyle, J.J. \& Doyle, J.L. 1987. A rapid DNA isolation procedure for small quantities of fresh leaf tissue. Phytochemical Bulletin 19: 11-15.

Dubé, M. and P. Morisset. 1996. La plasticité phénotipique des caractères anatomiques foliaires chez le Festuca rubra L. (Poaceae). Canadian Journal of Botany 74:1708-1718.

Dubcovsky, J. \& Martínez, A.J. 1987. Karyotypes and chromosomes meiotic behavior of Festuca pallescens (Poaceae). Darwiniana 28: 153-161. 
Dubcovsky, J. \& Martínez, A.J. 1988. Phenetic relationships in the Festuca spp. from Patagonia. Canadian Journal of Botany 66 (3): 468-478. http://dx.doi.org/10.1139/b88-072

Dubcovsky, J. \& Martínez, A.J. 1991. Chromosome complement and nucleoli in the Festuca pallescens alliance from South America. Canadian Journal of Botany 69(12): 2756-2761.

Dubcovsky, J. \& Martínez, A.J. 1992. Distribución geográfica de los niveles de ploidía en Festuca. Parodiana 7: 91-99.

Edgar, E. \& Connor, H.E. 2000. Flora of New Zealand. Vol. V. Gramineae. Manaaki Whenua Press, Lincoln, $650 \mathrm{pp}$.

Ellis, R.P. 1976. A procedure for standardizing comparative leaf anatomy in the Poaceae. I. The laefblade as view in transverse section. Bothalia 12(1): 65-109.

Ellis, R.P. 1979. A procedure for standarzing comparative leaf anatomy in the Poaceae. II. The epidermis as seen in surface wie. Bothalia 12(4): 641-671.

Eglinton, G. \& Hamilton, R.J. 1967. Leaf epicuticularwaxes. Science 156:1322-1335.

Escobar, I., Ruiz, E., Finot, V., Negritto, M.A. \& Baeza, C.M. 2011. Revisión taxonómica del género Eragrostis Wolf en Chile, basada en análisis estadísticos multivariados. Gayana Botánica 68(1): 49-85.

Evert, R. 2006. Esau, Anatomía Vegetal. Ediciones Omega. Barcelona.

Farris, J.S. 1983. The logical basis of phylogenetic analysis. En N. Platnick \& V. Funck (eds.), Proceedings of the Second Meeting of the Willi Hennig Society. Advances in Cladistics 2, pp. 1-47. New York: Columbia Univ. Press.

Felsenstein, J. 1985. Confidence limits on phylogenies: an approach using the bootstrap. Evolution 39: $783-791$.

Finot, V.L., Marticorena, C., Barrera, J.A., Muños-Schick, M. \& Negritto, M.A. 2009. Diversidad de la familia Poaceae (Gramineae) en la región del Bío-Bío, Chile, basada en colecciones de herbario. Gayana Botánica 66(2): 134-157.

Fuchs, J., Brandes, A. \& Schubert, I. 1995. Telomere sequence localization and karyotype evolution in higher plants. Plant Systematics and Evolution 196: 227-241. 
Gaut, B.S., Tredway, L.P., Kubik, C., Gaut, R.L. \& Meyer, W. 2000. Phylogenetic relationships and genetic diversity among members of the Festuca-Lolium complex (Poaceae) based on ITS sequence data. Plant Systematics and Evolution 224: 33-53.

Goloboff, P. A., Farris, J. S. \& Nixon, K. 2008. TNT, a free program for phylogenetics analysis. Cladistics 24: 774-786.

Gower, J.C. 1971. General coefficient of similarity and some of its properties. Biometrics 27: 857874.

Grisebach, A.H.R. 1874. Plantae Lorentzianae. Göttingen. Abhandlungen der Königlichen Gesellschaft der Wissenschaften zu Göttingen 19: 49-279.

Grisebach, A.H.R. 1879. Symbolae ad floram argentinam. Abhandlungen der Königlichen Gesellschaft der Wissenschaften zu Göttingen $24 \quad$ (1): 1-345. http://dx.doi.org/10.1007/BF00982962

Ghorai, A. \& Sharma, A. 1981. Chromosome studies in some Festuceae. Journal of the Indian Botanical Society 60: 148-153.

Hackel, E. 1882. Monographia Festucarum Europearum. Verlag von Theodor Fischer, Kassel und Berlín, 216 pp.

Hackel, E. 1907. Graminae. En P. Dusén (Ed.) Neue und seltene Gefässpflanzen aus Ostund Südpatagonien. Arkiv för Botanik utgivet av K. Svenska Vetenskapsakademien 7 (2): 4-11pp.

Hall, T.A. 1999. BioEdit: a userfriendly biological sequence aligment editor and analysis program for Windows 95/98/NT. Nucleic Acids Symposium Series. 41: 95-98.

Hattersley PW, Watson L, Johnston CR (1982) Remarkable leaf anatomical variations in Neurachne and its allies (Poaceae) in relation to $\mathrm{C} 3$ and $\mathrm{C} 4$ photosynthesis. Botanical Journal of the Linnean Society 84:265-272. doi:10.1111/j.1095-8339.1982.tb00364.x

Henderson, A.J. 2005. A multivariate study of Calyptrogyne (Palmae). Systematic Botany 30 (1): 6083.

Hillis, D.M., \& Wiens, J. J. 2000. Molecules versus morphology in systematics: Conflicts, artifacts, and misconceptions. En J.J.Wiens (ed.) Phylogenetic analysis of morphological data. Smithsonian Institution Press, Washington, D.C. 1-19 pp.

Hitchcock, A.S. 1927. The grasses of Ecuador, Peru, and Bolivia. Contributions from the United States National Herbarium 24(8): 291-556. 
Hooghiemstra, H., van der Hammen, T., 2004. Quaternary ice-age dynamics in the Colombian Andes: developing an understanding of our legacy. Philosophical Transactions of the Royal Society London B 359, 173-181.

Hsü, K.J., Montadert, L., Bernoulli, D., Cita, M.B., Erickson, A., Garrison, R.E., Kidd, R.B., Melieres, F., Müller, C. \& Wright, R. 1977. History of the Mediterranean salinity crisis. Nature 267, $399-402$.

Holub, J. 1984. New genera in Phanerogamae (1-3). Folia Geobotanica \& Phytotaxonomica 19: 9599.

Huelsenbeck, J. P., Larget, B., Miller, R. E. \& Ronquist, F. 2002. Potential applications and pitfalls of Bayesian inference of phylogeny. Systematic Biology 51: 673-688.

Inda, L.A., Segarra-Moragues, J.G., Müller, J., Peterson P.M. \& Catalán, P. 2008. Dated historical biogeography of the temperate Loliinae (Poaceae, Pooideae) grasses in the northern and southern hemispheres. Molecular Phylogenetics and Evolution 46: 932-957.

Infantes, J. 1952. Estudio botánico, químico y fitogeográfico de 27 especies del género Festuca. Revista de Ciencias (Lima) 54: 76-154.

Jauhar, P.P. 1975. Genetic regulation of diploid like chromosome pairing in the hexaploid species Festuca arundinacea Schreb. and F. rubra L. (Gramineae). Chromosoma 52: 363-382. http://dx.doi.org/10.1007/BF00364020

Jenkin, T. J. 1933. Interspecific and intergeneric hybrids in herbage grasses. Initial crosses. Journal of Genetics 28: 205-264.

Jongduk Jung, Seung Cho Lee, Hong-Keun Choi. 2008. Anatomical patternsof aerenchyma in aquatic and wetland plants. Journal of Plant Biology Volume 51, Issue 6, pp 428-439

Kellogg, E. A. 2001. Evolutionary history of the grasses. Plant Physiology 125: 1198-1205.

Kerguele, N. M. \& Lonka, F. P. 1989. Les Festuca de la flore de France (corse comprise). Bulletin de la Société Botanique du Centre-Ouest. Niort, Numero Special 10: 1-368.

Kjellqvist, E. 1961. Studies in Festuca rubra L. Influence of environment. Botaniska notiser 114: 403-408.

Kirschner, J., Stepanek, J. \& Stepankova, J. 1982. In IOPB chromosome number reports LXXVI. Taxon 31: 574-575. 
Laegaard, S. 1999. Festuca. En P. M. Jørgensen \& S. León-Yánez (eds.). Catalogue of the Vascular Plants of Ecuador, Vol. 75, pp 819-820. Missouri Botanical Garden Press, Saint Louis.

Lazarides, M. 2002. Economic attributes of Australian grasses. En K. Mallet \& Orchard, A.E. (eds.) Flora of Australia. Vol. 43. Poaceae1: Introduction and Atlas. ABRS, Melboure, 213-244 pp.

Lloyd K.M., Hunter A.M., Orlovich D.A., Draffin S.J., Stewart A.V., \& Lee, W.G. 2007. Phylogeny and biogeography of endemic Festuca (Poaceae) from New Zealand based on nuclear (ITS) and chloroplast (trnL-trnF) nucleotide sequences. Aliso: A Journal of Systematic and Evolutionary Botany 23:406-419

Macbride, J.F. 1936. Gramineae. En B.E. Dahlgren (ed.), Flora of Peru. Field Museum of Natural History, Botanical Series XIII Part 1. Chicago. 96-261 pp.

Malik, C.P. \& Thomas, P.T. 1966. Karyotypic studies in some Lolium and Festuca species. Caryologia 19: 167-196.

Markgraf-Dannenberg, I. 1980. Festuca. En T.G. Tutin, V.H. Heywood, N.A. Burges, D.M. Moore, D.H. Valentine, S.M. Walters \& Webb. D.A. (eds.) Flora Europaea, Vol. 5, Cambridge University Press, Cambridge, UK

Marticorena, C. \& Quezada, M. 1985. Catálogo de la flora vascular de Chile. Gayana Botánica 42: 5157.

Matthei, J.O. 1982. El género Festuca (Poaceae) en Chile. Gayana Botánica 37: 1-64.

McNeill, J. 2014. Holotype specimens and type citations: General issues. Taxon 63: 1112-1113. http://dx.doi.org/10.12705/635.7

McNeill, J., Barrie, F.R., Buck, W.R., Demoulin, V., Greuter, W., Hawkswoth, D.L., Herendeen, P.S., Kanpp, S., Marhhold, K., Prado, J., Prud'homme van Reine, W.F., Smith, G.F., Wiersema, J.H. \& Turland, N.J. 2012. International Code of Nomenclature for Algae, Fungi and Plants (Melbourne Code): Adopted by the Eighteenth International Botanical Congress Melbourne, Australia, July 2011. Koeltz Scientific Books, Königstein, 240 pp.

Metcalfe, C.R. 1960. Anatomy of the Monocotyledons. I. Gramineae, Clarendon Press, Oxford. 731 pp.

Müller, J. \& Catalán, P. 2006. Notes on the infrageneric classification of Festuca L. (Gramineae). Taxon 55: 139-144. 
Namaganda, M. \& Lye K.A. 2008. A taxonomic comparison between tropical African and related European broad-leaved species of Festuca L. (Poaceae). South African Journal of Botany 74 (2): 295-305.

Namaganda, M., T. Krekling \& Lye K. A. 2009. Leaf anatomical characteristics of Ugandan species of Festuca L. (Poaceae). South African Journal of Botany 75: 52-59.

Nicora, E.G. 1978. Gramineae. En M.N. Correa (ed.), Flora Patagónica, parte III. Colección Científica del I.N.T.A. Buenos Aires. 581 pp.

Nicora, E.G. \& Rúgolo de Agrasar, Z.E. 1998. Tipos de Gramíneas conservados en el herbario Gaspar Xúarez, Buenos Aires (BAA) procedentes de Berlín (B). Darwiniana 36: 163-199.

Olson D.M, Dinerstein, E., Wikramanayake, E.D., Burgess, N.D., Powell, G.V.N.,. Underwood, E.C, D'amico, J.A., Itoua, I., Strand, H. E., Morrison, J.C., Loucks, C.J., Allnutt, T.F., Ricketts, T.H., Kura, Y., Lamoreux, J.F., Wettengel, W.W., Hedao, P. \& Kassem, K.R. 2001. Terrestrial ecoregions of the world: A new map of life on Earth. BioScience 51: 933-938.

Ortúñez, E. \& de la Fuente, V. 2010. Epidermal micromorphology of the genus Festuca L. (Poaceae) in the Iberian Peninsula. Plant Systematics and Evolution 284: 201-218. http://dx.doi.org/10.1007/s00606-009-0248-7

Ortúñez, E. \& Cano-Ruiz, J. 2013. Epidermal micromorphology of the genus Festuca L. subgenus Festuca (Poaceae). Plant Systematics and Evolution 299 (8): 1471-1483. http://dx.doi.org/10.1007/s00606-013-0809-7

Ospina, J.C., Aliscioni, S.S. \& Denham, S.S. 2013a. Estudios taxonómicos en el género Festuca L. (Poaceae) de Argentina y Chile. Gayana Botánica 70: 1-15. http://dx.doi.org/10.4067/S071766432013000100001

Ospina, J.C., Aliscioni, S.S. \& Denham, S.S. 2013b. Festuca rigescens (Poaceae, Pooideae, Loliinae) en Argentina y Chile. Darwiniana 1: 162-172. http://dx.doi.org/10.14522/darwiniana.2013.11.538

Ospina, J.C., Aliscioni, S.S. \& Denham, S.S. 2013b. A revisión of Festuca (Loliinae, Pooideae, Poaceae) in Chile. Phytotaxa 223 (1):001-066. http://dx.doi.org/10.11646/phytotaxa.223.1.1

Parodi, L.R. 1935. Notas sobre gramineas argentinas. Physis 11: 497-500.

Parodi, L.R. 1953. Las especies de Festuca de la Patagonia. Revista Argentina de Agronomía 20: 177229. 
Pilger, R. 1906. Gramineae andinae. III. Botanische Jahrbücher für Systematik, Pflanzengeschichte und Pflanzengeographie 37: 504-517.

Piper, C.V. 1906. North American species of Festuca. Contributions from the United States National Herbarium 10: 1-48.

Piper, C.V. 1913. Supplementary notes on American species of Festuca. Contributions from the United States National Herbarium16: 197-200.

Posada, D. \& Crandall, K. A. 1998. Modeltest: testing the model of DNA substitution. Bioinformatics 14: $817-818$.

Posada, D. \& Buckley, T.R. 2004. Model Selection and Model Averaging in Phylogenetics: Advantages of Akaike Information Criterion and Bayesian Approaches Over Likelihood Ratio Tests. Systematic Biology 53: 793-808.

Prado, J., Hirai, R.Y. \& Moran, R.C. 2015. (046-048) Proposals concerning inadvertent lectotypifications (and neotypifications). Taxon 64: 651-651. http://dx.doi.org/10.12705/643.29.

Rambaut, A. \& A. J. Drummond. 2007. Tracer v1.4. Available from: <http:// beast.bio.ed.ac.uk/Tracer>.

Rangel Churio, O.J., Lowy, P.D.C. \& M.P. Aguilar. 1997. Colombia Diversidad Biotica II. I.C. N., Universidad Nacional de Colombia, Bogotá. 436 pp.

Rangel Churio, O.J. 2000. Colombia Diversidad Biótica III. La región de vida paramuna. Editorial Unibiblos, Universidad Nacional de Colombia, Bogotá. 902 pp.

Renvoize, S.A. 1998. Gramineas deBolivia. Kew, London. 664 pp.

Ronquist F., Teslenko, M., Mark, P. van der, Ayres, D.L., Darling, A., Höhna, S., Larget, B., Liu, L., Suchard, M.A. \& Huelsenbeck J.P. 2012. Mrbayes 3.2: Efficient bayesian phylogenetic inference and model choice across alarge model space. Systematic Biology 61:539-542.

Rudall, P.J. 2007. Anatomy of the Flowering Plants. Cambridge Univ. Press, New York.

Rúgolo de Agrasar, Z.E. \& Nicora, E.G. 1988. Nuevos taxones para la Argentina y Chile austral (Gramineae). Boletín de la Sociedad Argentina de Botánica 25: 462-476.

Ruzin, S.E. 1999. Plant microtechnique and microscopy. University Press, Oxford. 322 pp. 
Saint-Yves, A. 1927. Contribution a l'étude des Festuca (subg. Eu-Festuca) de l'Amérique du Sud. Candollea. 3: 15-315.

Saint-Yves, A. 1932. Festucae novae et loci novi Festucarum jam cognitarum (sugen. Eu-Festuca). Candollea 5: 101-141.

Simmons, M.P. \& Ochoterena, H. 2000. Gaps and characters in sequence-based phylogenetic analyses. Systemaic Biology 49(2): 369-381.

Soreng, R.J., Davis, J.I. \& Doyle, J.J. 1990. A phylogenetic analysis of chloroplast DNA restriction site variation in Poaceae subfam. Pooideae. Plant Systematics and Evolution 172: 83-97. http://dx.doi.org/10.1007/BF00937800

Soreng, R.J., Davis, J.I. \& Voionmaa, M.A.. 2007. A phylogenetic analysis of Poaceae tribe Poeae sensu lato based on morphological characters and sequence data from three plastid-encoded genes: Evidence for reticulation, and a new classification for the tribe. Kew Bulletin 62: 425454.

Soreng, R.J., Peterson, P.M., Romaschenko, K., Davidse, G., Zuloaga, F.O., Judziewicz, E.J., Filgueiras, T.S., Davis, J.I. \& Morrone, O. 2015. A worldwide phylogenetic classification of the Poaceae (Gramineae). Journal of Systematics and Evolution 53: 117-137. http://dx.doi.org/10.1111/jse.12150

Spies, J.J., Wyk, S.M.C. v., Nieman, I.C. \& Liebenberg, E.J.L. 1997. Cytogenetic studies in some representatives of the subfamily Pooideae (Poaceae) in South Africa. 3. The tribe Poeae. Bothalia 27: 75-82.

Spies, J. J., Burger, T.H. \& Wyk, S.M.C. v. 1999. Chromosome studies on African plants. 12. The tribes of subfamily Pooideae. Bothalia 29(2): 335-341.

Stace, C. A. 1965. Cuticular studies as an aid to plant taxonomy. Bulletin of the British Museum (Natural History). Botany 4: 1-78.

Stace, M. 2012. Vulpia. En A. M. Anton \& F. O. Zuloaga (eds). Flora de Argentina, Vol. 3, Tomo II. Gráficamente Ediciones, Córdoba, Argentina. 365-369 pp.

Stammers, M., Harris, J., Evans, G.M., Hayward, M.D. \& Forster, J.W. 1995. Use of random PCR (RAPD) technology to analyse phylogenetic relationships in the Lolium/Festuca complex. Heredity $74: 19-27$. 
Stančík, D. 2001. New records of the genus Festuca L. (Poaceae) for Colombia and Venezuela. Caldasia 23: 337-339.

Stančík, D. 2003a. The genus Festuca (Poaceae) in Colombia. Darwiniana 41(1-4): 93-153

Stančík, D. 2003b. New endemic taxa in Festuca (Poaceae) from Colombian Sierra Nevada de Santa Marta. Preslia 75: 1-9.

Stančík, D. \& Peterson, P.M.. 2007. A revision of Festuca (Poaceae: Loliinae) in South American Paramos. Contributions from the United States National Herbarium 56: 1-184.

Strömberg, C.A.E. 2011 . Evolution of grasses and grassland ecosystems. Annual Review of Earth and Planetary Sciences 39: 517-544.

Stuckert, T. 1906. Segunda contribución al conocimiento de las gramináceas argentinas. Anales del Museo Nacional de Historia Natural de Buenos Aires 3(6): 409-555.

Thiers, B. [continuously updated, accessed 2015] Index Herbariorum: a global directory of public herbaria and associated staff. New York Botanical Garden's Virtual Herbarium, URL: http://sweetgum.nybg.org/ih.

Thompson J.D., Higgins, D.G. \& Gibson T. J. 1994. CLUSTAL W: improving the sensitivity of progressive multiple sequence alignment through sequence weighting, position-specific gap penalties and weight matrix choice. Nucleic Acids Research 22:4673-4680.

Tiffney, B.H., 1985. The Eocene North Atlantic land bridge: its importance in Tertiary and modern phylogeography of the northern hemisphere. Journal Arnold Arboretum 66: 243-273.

Torrecilla, P. \& Catalán, P. 2002. Phylogeny of broad-leaved and fine-leaved Festuca linages (Poaceae) based on nuclear ITS sequences. Systematic Botany 27 (2): 241-251.

Torrecilla, P., López-Rodríguez, J.A., Stancik, D. \& Catalán, P. 2003. Systematics of Festuca L. sects. Eskia Willk., Pseudatropis Kriv., Amphigenes (Janka) Tzvel., Pseudoscariosa Kriv. and Scariosae Hack. based on analysis of morphological characters and DNA sequences. Plant Systematics and Evolution 239: 113-139.

Torrecilla, P., López-Rodríguez, J.A. \& Catalán, P. 2004. Phylogenetic relationships of Vulpia and related genera (Poeae, Poaceae) based on analysis of ITS and trnL-F sequences. Annals of Missouri Botanical Garden (91): 124-158.

Tovar, O. 1972. Revisión de las especies peruanas del género Festuca, Gramineae. Memorias del Museo de Historia Natural "Javier Prado” 16: 1-93. 
Tovar, O. 1993. Las gramineas (Poaceae) del Perú. Ruizia 13: 1-480.

Turland, N. 2013. The Code Decoded: a user's Guide to the International Code of Nomenclature algae, fungi, and plants [Regnum Vegetabile no. 155.]. Königstein: Koeltz Scientific Books.

Türpe, A.M. 1969. Las especies argentinas de Festuca. Darwiniana 15: 189-283.

Türpe, A.M. 1998. Novedades en gramineae para la flora argentina. Hickenia 57(2): 267-272.

Tzvelev, N. N. 1971. K sistematike i filogenii ovsjaniz (Festuca L.) flory S.S.S.R. I. Sistema roda ioshoriye naprav'enija evoljuzii. Botaničeskii Žhurnal (Moscow \& Leningrad) 56: 1252-1262.

Tzvelev, N.N. 1976. Poaceae USSR. Nauka, Leningrad. (in Russian) Translated as Grasses of the Soviet Union Zlaki SSSR. Nauka, Leningrad. Published for Smithsonian Institution Libraries and National Science Foundation. 1983. Oxonian, New Delhi, India.

Tzvelev, N. N.1982. Poryadok zlaki (Poales). Zhizn Rast 6: 341-378.

Watson, L., \& Allwitz, M. J. D. 1992. The grass genera of the world. CAB International, Wallingford, Oxfordshire, UK. 1038 p.

Xu, W.W. \& Sleper, D.A. 1994. Phylogeny of tall fescue and related species using RFLPs. Theoretical and Applied Genetics 88: 685-690.

Yang, Z. \& Rannala, B. 1997. Bayesian phylogenetic inference using DNA sequences: A markov chain Monte Carlo method. Molecular Biology and Evolution 14: 717-724

Zarinkamar, F. 2008. Iranian atlas of foliar anatomy. Vol. 1. Noorbakhsh Press, Teheran.

Zarinkamar, F. \& Jouyandeh, N.E. 2011. Foliar anatomy and micromorphology of Festuca and its taxonomic applications. Taxonomy and Biosystematics 8: 55-63.

Zuloaga, F.O., Morrone, O. \& Belgrano, M. (eds). 2008. Catálogo de las Plantas Vasculares del Cono Sur. I. Pteridophyta, Gymnospermae y Monocotyledoneae. Missouri Botanical Garden Press, Saint Louis. 983 pp. 